ENVIRONMENTAL GUIDANCE PROGRAM REFERENCE BOOK

TOXIC SUBSTANCES CONTROL ACT

\author{
Prepared for \\ ASSISTANT SECRETARY FOR ENVIRONMENT, \\ SAFETY AND HEALTH \\ OFFICE OF ENVIRONMENTAL GUIDANCE \\ (B/A No. HA 011500 0; EHHAOO2)
}

Prepared by the

ENVIRONMENTAL SCIENCES DIVISION

Oak Ridge National Laboratory

Oak Ridge, Tennessee 37831-6285

managed by

MARTIN MARIETTA ENERGY SYSTEMS, INC.

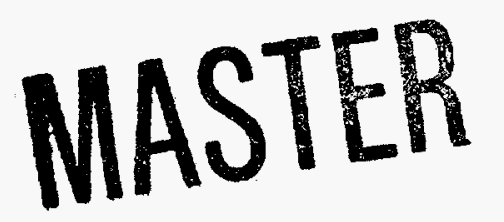

for the

U.S. DEPARTMENT OF ENERGY

under Contract No. DE-AC05-84OR21400 
○

-

○ 


\section{DISCLAIMER}

This report was prepared as an account of work sponsored by an agency of the United States Government. Neither the United States Government nor any agency thereof, nor any of their employees, make any warranty, express or implied, or assumes any legal liability or responsibility for the accuracy, completeness, or usefulness of any information, apparatus, product, or process disclosed, or represents that its use would not infringe privately owned rights. Reference herein to any specific commercial product, process, or service by trade name, trademark, manufacturer, or otherwise does not necessarily constitute or imply its endorsement, recommendation, or favoring by the United States Government or any agency thereof. The views and opinions of authors expressed herein do not necessarily state or reflect those of the United States Government or any agency thereof. 


\section{DISCLAIMER}

Portions of this document may be illegible in electronic image products. Images are produced from the best available original document. 
Date

\section{CHANGES IN REFERENCE BOOK DISTRIBUTION}

Please modify the distribution for the Toxic Substances Control Act Reference Book by (check one):

Adding:

Deleting:

Correcting the address as indicated:

Removing and adding:

Name:

Address:

Phone:

Please send this form to:

Cynthia G. Heckman

800 TPK, MS-6482

Oak Ridge National Laboratory

P.O. Box 2008

Oak Ridge, TN 37831-6482 
The following Environmental Guidance Program Reference Books are available to Department of Energy personnel upon request. If you are not currently on the distribution list for a particular Reference Book, but would like to receive a copy of any of the following books, please complete the form below and return to:

Cynthia G. Heckman

Oak Ridge National Laboratory

800 TPK, MS-6482

P.O. Box 2008

Oak Ridge, TN 37831-6482

Requests may be forwarded to EH-23, Office of Environmental Guidance, for approval.

NAME:

AFFILIATION:

ADDRESS:

PHONE:

Please place a check mark in the space provided to the left of the title of the book(s) that you would like to receive.

\section{REFERENCE BOOKS}

American Indian Religious Freedom Act

Atomic Energy Act and Related Legislation

Clean Air Act

Clean Water Act (excluding Section 404)

Clean Water Act (Section 404) and the Rivers and Harbors Act (Sections 9 \& 10)

Coastal Zone Management Act

Comprehensive Environmental Response, Compensation, and Liability Act

Endangered Species Act and the Fish and Wildlife Coordination Act

Marine Protection, Research, and Sanctuaries Act and the Marine Mammal Protection Act

National Historic Preservation Act and Related Legislation

Resource Conservation and Recovery Act

Safe Drinking Water Act

Toxic Substances Control Act 
$\bullet$

-

- 


\section{PREFACE}

This Reference Book contains a current copy of the Toxic Substances Control Act and those regulations that implement the statute and appear to be most relevant to DOE activities. The document is provided to DOE staff for informational purposes only and should not be interpreted as legal guidance. Questions concerning this Reference Book may be directed to Mark Petts, EH-231 (202/586-2609). 
$\bullet$

- 


\section{UPDATE INSTRUCTIONS}

\section{ENVIRONMENTAL GUIDANCE PROGRAM REFERENCE BOOK TOXIC SUBSTANCES CONTROL ACT}

December 1, 1994

This reference book on the Toxic Substances Control Act (TSCA) has been completely revised and is current through December 1, 1994.

Instructions for updating the Reference Book with December 1, 1994, revision 7 materials are as follows:

- Remove all existing materials (except dividers), Sections 1-4, and replace with new materials in a loose-leaf binder.

Any information regarding modifications in the distribution list of this Reference Book, including additions, deletions, and address changes, should be conveyed to Cindy Heckman by calling her (615/574-7317) or by sending them to her at the following location:

Cindy Heckman

800 TPK, MS-6482

Oak Ridge National Laboratory

P.O. Box 2008

Oak Ridge, TN 37831-6482

FAX: (615) 241-3800 


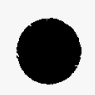

-

- 


\section{CONTENTS}

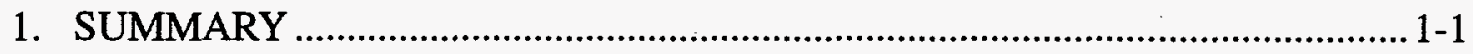

2. LEGISLATIVE HISTORY AND STATUTE ................................................... 2-1

The Toxic Substances Control Act of 1976, as amended .................................2-3

3. IMPLEMENTING REGULATIONS .........................................................

40 CFR 717-Records and Reports of Allegations that Chemical

Substances Cause Significant Adverse Reactions to Health or the Environment

40 CFR 761-Polychlorinated Biphenyls (PCBs) Manufacturing,

Processing, Distribution in Commerce, and Use Prohibitions .............................3-13

40 CFR 792—Good Laboratory Practice Standards .......................................... 3-81

4. TOXIC SUBSTANCES CONTROL ACT (TSCA) UPDATE .............................4-1 
1. SUMMARY 


\section{SECTION 1. SUMMARY}

The purpose of the Toxic Substances Control Act (TSCA) is to protect human health and the environment by requiring that specific chemicals be tested and that regulations restricting their processing and use be implemented.

The objectives of TSCA include the development of adequate data to determine the health and environmental effects of chemicals and to control the manufacturing, processing, distribution in commerce, use, and/or disposal of any chemicals that may present an unreasonable risk of injury. The sections of the Act most relevant to the Department of Energy (DOE) deal with requirements for:

- The practice of good laboratory standards for conducting studies relating to health effects, environmental effects, and chemical fate testing. (Section 4)

- Regulating certain chemicals such as polychlorinated biphenyls (PCBs) that may be used in DOE facilities or processes. (Section 6)

- Maintaining long-term records on adverse reactions to health and environment alleged to have been caused by a substance or mixture and to permit inspection and submit copies of such records. (Section 8)

The primary way TSCA impacts DOE is through its regulation of PCBs. Other regulations restrict the availability of materials for purchase by DOE. Regulations important to DOE include the following from Title 40 of the Code of Federal Regulations (CFR):

- 40 CFR 717-Records and Reports of Allegations that Chemical Substances Cause Significant Adverse Reactions to Health or the Environment;

- 40 CFR 761 - Polychlorinated Biphenyls (PCBs) Manufacturing, Processing, Distribution in Commerce, and Use Prohibitions; and

- 40 CFR 792 - Good Laboratory Practice Standards.

Brief summaries of these regulations may be found in Section 3 (Implementing Regulations) of this Reference Book. 
Determinations regarding compliance with TSCA must be made on a case-specific basis if a DOE activity involves the manufacture, processing, distribution in commerce, use, and/or disposal of a new or existing chemical substance or mixture that may present an unreasonable risk of injury to health or the environment.

Although the definition of "chemical substances" explicitly excludes from its scope several materials that might otherwise meet the definition, including those that are regulated under other federal statues, TSCA is potentially applicable to all "chemical substances" and "mixtures" that are manufactured, imported, processed, used, distributed, and/or disposed of in the United States. By definition TSCA regulated chemical substances and mixtures do not include "... any source material, special nuclear material, or byproduct material (as such terms are defined in the Atomic Energy Act of 1954 and regulations issued under such Act) ..." [TSCA, Section 3(2)(B)(iv)]. Although TSCA excludes nuclear material, the TSCA-regulated portion of a mixed nuclear and regulated waste must comply with TSCA requirements. Materials that are not chemical substances or mixtures are not subject to the various requirements of TSCA.

The TSCA program is run by the Environmental Protection Agency (EPA) and is not delegated to any state agency. 


\section{LEGISLATIVE HISTORY AND STATUTE}




\section{SECTION 2. LEGISLATIVE HISTORY AND STATUTE}

First proposed by President Nixon in February 1971, the Toxic Substances Control Act (TSCA) was enacted by the U.S. Congress in 1976 and became effective January 1 , 1977. The Act authorizes EPA to secure information on all new and existing chemical substances and to control any of these substances determined to cause an unreasonable risk to public health or the environment. EPA already had the authority, under laws enacted earlier, to regulate (1) discharges of toxic substances into waterways (Clean Water Act) and drinking water (Safe Drinking Water Act), (2) emissions into the air (Clean Air Act), (3) disposal of toxic and hazardous wastes (Resource Conservation and Recovery Act), and (4) the adverse effects of pesticide products (Federal Insecticide, Fungicide, and Rodenticide Act). However, EPA's authority was limited to controlling toxic substances after damage was done, so EPA was reacting to toxic problems after they occurred rather than preventing them. In addition, the other laws did not require the screening of toxic substances before they entered the marketplace.

TSCA, therefore, closed the gaps in the earlier laws by requiring that the health and environmental effects of all new chemicals be reviewed before they are manufactured for commercial purposes. With TSCA's authority, in addition, the federal government can gather information on existing chemical substances to determine their potential for damaging human health and the environment and regulate these chemcials.

The legislative history for TSCA is contained in the following documents:

- House Report No. 94-1341 accompanying H.R. 14032 (Interstate and Foreign Commerce Committee),

- Senate Report No. 94-698 accompanying S. 3149 (Committee on Commerce),

- House Conference Report No. 94-1679 accompanying S. 3149, and

- Senate Conference Report No. 94-1302 accompanying S. 3149.

TSCA was considered in the Senate on March 26, 1976, and the Senate bill in lieu of the House bill was passed by the Senate on September 28, 1976. The House considered TSCA on August 23, 1976, and passed the Senate bill on September 28, 1976. TSCA was signed on October 11, 1976, as Public Law (Pub. L.) 94-469. Minor amendments to the Act were promulgated by Pub. L. 97-129 (December 29, 1981), Pub. L. 98-80 (August 23, 1983), Pub. L. 98-620 (November 8, 1984), and Pub. L. 100-418 (August 23, 1988). Other amendments to TSCA are discussed below. 
The Asbestos Hazard Emergency Response Act (AHERA, Pub. L. 99-519), enacted by Congress on October 22, 1986, authorizes EPA to amend its TSCA regulations to impose more requirements on asbestos abatement in schools. AHERA provides for the promulgation of federal regulations requiring inspection for asbestos and appropriate response actions in schools and mandates periodic reinspection. In addition, it requires the EPA Administrator to determine "the extent of the danger to human health posed by asbestos in public and commercial buildings and the means to respond to any such danger."

Although AHERA's impact is currently largely restricted to schools, it establishes a precedent for requirements which might eventually affect public and commercial buildings. AHERA imposes specific requirements or mandates promulgation of specific regulations in the following areas: circumstances requiring response, response actions, operations/maintenance and repair programs, periodic surveillance, transport and disposal, development of asbestos management plans, and use of warning labels.

TSCA was amended on July 18, 1988 (Pub. L. 100-368), to provide adequate time for local educational agencies to submit asbestos management plans to governors and to begin implementation of those plans.

The Asbestos School Hazard Abatement Reauthorization Act of 1990 (Pub. L. 101-637, November 28, 1990) amended TSCA to require accreditation for asbestos abatement contractors working in public or commercial buildings.

A new Title III of TSCA, Indoor Radon Abatement, was added on October 28, 1988 (Pub. L. 100-551). The purpose of this legislation was to "amend the Toxic Substances Control Act to assist States in responding to the threat to human health posed by exposure to radon." The law authorized appropriations from fiscal year 1989 through fiscal year 1991 for EPA technical and financial assistance to states in developing radon gas testing and mitigation programs. The programs included training of technical personnel, collection and dissemination of public information, and education on radon health risks and mitigation methods. Section 309 of the act requires that: "The head of each Federal department or agency that owns a Federal building shall conduct a study for the purpose of determining the extent of radon contamination in such buildings."

Title III of TSCA was amended on November 5, 1990 (Pub. L. 101-508), by establishing a mandatory proficiency testing program study and requiring research to develop, test, and evaluate radon and radon progeny measurement methods and protocols.

Title IV of TSCA, Lead Exposure Reduction, was added on October 28, 1992 (Pub. L. 102-550). The purpose of this legislation is to reduce environmental lead contamination and prevent adverse health effects as a result of lead exposure, particularly in children. Provisions include requirements for identifying lead-based paint hazards; defining levels of lead allowed in various products, including paint and toys; and establishing state 
programs for the monitoring and abatement of lead exposure levels, including training and certification for lead abatement workers.

A copy of the TSCA statute, as amended, follows. 
December 1, 1994

Revision 7

\section{BLANK PAGE}




\section{TOXIC SUBSTANCES CONTROL ACT}

\section{as amended ${ }^{1}$ \\ U.S.C. $\$ 2601$ et seq. \\ TITLE I-CONTROL OF TOXIC SUBSTANCES}

Sec. 2. Findings, policy, and intent.

Sec. 3. Definitions.

Sec. 4. Testing of chemical substances and mixtures.

Sec. 5. Manufacturing and processing notices.

Sec. 6. Regulation of hazardous chemical substances and mixtures.

Sec. 7. Imminent Hazards.

Sec. 8. Reporting and retention of information.

Sec. 9. Relationship to other federal laws.

Sec. 10. Research, development, collection, dissemination, and utilization of data.

Sec. 11. Inspections and subpoenas.

Sec. 12. Exports.

Sec. 13. Entry into customs territory of the United States.

Sec. 14. Disclosure of data.

Sec. 15. Prohibited acts.

Sec. 16. Penalties.

Sec. 17. Specific enforcement and seizure.

Sec. 18. Preemption.

Sec. 19. Judicial review.

Sec. 20. Citizens' civil actions.

Sec. 21. Citizens' petitions.

Sec. 22. National defense waiver.

Sec. 23. Employee protection.

Sec. 24. Employment effects.

Sec. 25. Studies.

Sec. 26. Administration.

Sec. 27. Development and evaluation of test methods.

Sec. 28. State programs.

Sec. 29. Authorization of appropriations.

Sec. 30. Annual Report.

\section{TITLE II-ASBESTOS HAZARD EMERGENCY RESPONSE}

Sec. 201. Congressional findings and purpose.

Sec. 202. Definitions.

Sec. 203. EPA regulations.

Sec. 204. Requirements if EPA fails to promulgate regulations.

Sec. 205. Submission to State Governor.

Sec. 206. Contractor and laboratory accreditation.

Sec. 207. Enforcement.

Sec. 208. Emergency authority.

Sec. 209. State and Federal law.

\footnotetext{
${ }^{1}$ Public Law 94-469, October 11, 1976, as amended by PL 97-129, December 29, 1981; PL 98-80, August 23, 1983; PL 98-620, November 8, 1984; PL 99-519, October 22, 1986; PL 100-11, March 17, 1987; PL 100-202, December 22, 1987; PL 100-268, July 18, 1988; PL 100-368, July 18, 1988; PL 100-418, August 23, 1988; PL 100-551, October 28, 1988; and PL 100-577, October 31, 1988; PL 101-508, November 5, 1990; PL 101-637, November 28, 1990; PL 102-129, October 15, 1991; PL 102-550, October 28, 1992.
} 
Sec. 210. Asbestos contractors and local educational agencies.

Sec. 211. Public protection.

Sec. 212. Asbestos Ombudsman.

Sec. 213. EPA study of asbestos-containing materials in public buildings.

Sec. 214. Transition rules.

Sec. 215. Worker protection.

Sec. 216. Training grants.

\section{TITLE III-INDOOR RADON ABATEMENT}

Sec. 301. National goal.

Sec. 302. Definitions.

Sec. 303. EPA Citizen's guide.

Sec. 304. Model construction standards and techniques.

Sec. 305. Technical assistance to states for radon programs.

Sec. 306. Grant assistance to states for radon programs.

Sec. 307. Radon in schools.

Sec. 308. Regional radon training centers.

Sec. 309. Study of radon in federal buildings.

Sec. 310. Regulations.

Sec. 311. Additional authorizations.

\section{TITLE IV-LEAD EXPOSURE REDUCTION}

Sec. 401. Definitions.

Sec. 402. Lead-based paint activities training and certification.

Sec. 403. Identification of dangerous levels of lead.

Sec. 404. Authorized state programs.

Sec. 405. Lead abatement and measurement.

Sec. 406. Lead hazard information pamphlet.

Sec. 407. Regulations.

Sec. 408. Control of lead-based paint hazards at federal facilities.

Sec. 409. Prohibited acts.

Sec. 410. Relationship to other Federal law.

Sec. 411. General provisions relating to administrative proceedings.

Sec. 412. Authorization of appropriations.

\section{TITLE I-CONTROL OF TOXIC SUBSTANCES}

Findings, Policy, and Intent

[15 U.S.C. 2601]

Sec. 2. (a) Findings.-The Congress finds that-

(1) human beings and the environment are being exposed each year to a large number of chemical substances and mixtures;

(2) among the many chemical substances and mixtures which are constantly being developed and produced, there are some whose manufacture, processing, distribution in commerce, use, or disposal may present an unreasonable risk of injury to health or the environment; and

(3) the effective regulation of interstate commerce in such chemical substances and mixtures also necessitates the regulation of intrastate commerce in such chemical substances and mixtures.

(b) Policy.-It is the policy of the United States that-

(1) adequate data should be developed with respect to the effect of chemical substances and mixtures on health and the environment and that the development of such data should be the responsibility of those who manufacture and those who process such chemical substances and mixtures;

(2) adequate authority should exist to regulate chemical substances and mixtures which present an unreasonable risk of injury to health or the environment, and to take action with respect to chemical substances and mixtures which are imminent hazards; and 
(3) authority over chemical substances and mixtures should be exercised in such a manner as not to impede unduly or create unnecessary economic barriers to technological innovation while fulfilling the primary purpose of this Act to assure that such innovation and commerce in such chemical substances and mixtures do not present an unreasonable risk of injury to health or the environment.

(c) Intent of Congress.-It is the intent of Congress that the Administrator shall carry out this Act in a reasonable and prudent manner, and that the Administrator shall consider the environmental, economic, and social impact of any action the Administrator takes or proposes to take under this Act.

Definitions

[15 U.S.C. 2602]

Sec. 3. As used in this Act [15 U.S.C. 2601 et seq.]:

(1) the term "Administrator" means the Administrator of the Environmental Protection Agency.

(2) (A) Except as provided in subparagraph (B), the term "chemical substance" means any organic or inorganic substance of a particular molecular identity, including-

(i) any combination of such substances occurring in whole or in part as a result of a chemical reaction or occurring in nature, and

(ii) any element or uncombined radical.

(B) Such term does not include-

(i) any mixture,

(ii) any pesticide (as defined in the Federal Insecticide, Fungicide, and Rodenticide Act [7 U.S.C.

136 et seq.]) when manufactured, processed, or distributed in commerce for use as a pesticide,

(iii) tobacco or any tobacco product,

(iv) any source material, special nuclear material, or byproduct material (as such terms are defined in the Atomic Energy Act of 1954 [42 U.S.C. 2011 et seq.] and regulations issued under such Act), (v) any article the sale of which is subject to the tax imposed by section 4181 of the Internal Revenue Code of 1954 [26 U.S.C. 4181] (determined without regard to any exemptions from such tax provided by section 4182 or 4221 [26 U.S.C. 4182,4221 ] or any other provision of such Code), and

(vi) any food, food additive, drug, cosmetic, or device (as such terms are defined in section 201 of the Federal Food, Drug, and Cosmetic Act [21 U.S.C. 321]) when manufactured, processed, or distributed in commerce for use as a food, food additive, drug, cosmetic, or device.

The term "food" as used in clause (vi) of this subparagraph includes poultry and poultry products (as defined in sections 4(e) and 4(f) of the Poultry Products Inspection Act [21 U.S.C. 453]), meat and meat food products (as defined in section 1(j) of the Federal Meat Inspection Act [21 U.S.C. 601(j)]), and eggs and egg products (as defined in section 4 of the Egg Products Inspection Act [21 U.S.C. 1033]).

(3) The term "commerce" means trade, traffic, transportation, or other commerce (A) between a place in a State and any place outside of such State, or (B) which affects trade, traffic, transportation, or commerce described in clause (A).

(4) The terms "distribute in commerce" and "distribution in commerce" when used to describe an action taken with respect to a chemical substance or mixture or article containing a substance or mixture mean to sell, or the sale of, the substance, mixture, or article in commerce; to introduce or deliver for introduction into commerce, or the introduction or delivery for introduction into commerce of, the substance, mixture, or article; or to hold, or the holding of, the substance, mixture, or article after its introduction into commerce. (5) The term "environment" includes water, air, and land and the interrelationship which exists among and between water, air, and land and all living things.

(6) The term "health and safety study" means any study of any effect of a chemical substance or mixture on health or the environment or on both, including underlying data and epidemiological studies, studies of occupational exposure to a chemical substance or mixture, toxicological, clinical, and ecological studies of a chemical substance or mixture, and any test performed pursuant to this Act.

(7) The term "manufacture" means to import into the customs territory of the United States (as defined in general note 2 of the Harmonized Tariff Schedule of the United States [19 U.S.C. 1202]), produce, or manufacture. 
(8) The term "mixture" means any combination of two or more chemical substances if the combination does not occur in nature and is not, in whole or in part, the result of a chemical reaction; except that such term does include any combination which occurs, in whole or in part, as a result of a chemical reaction if none of the chemical substances comprising the combination is a new chemical substance and if the combination could have been manufactured for commercial purposes without a chemical reaction at the time the chemical substances comprising the combination were combined.

(9) The term "new chemical substance" means any chemical substance which is not included in the chemical substance list compiled and published under section 8(b) [15 U.S.C. 2607(b)].

(10) The term "process" means the preparation of a chemical substance or mixture, after its manufacture, for distribution in commerce-

(A) in the same form or physical state as, or in a different form or physical state from, that in which it was received by the person so preparing such substance or mixture, or

(B) as part of an article containing the chemical substance or mixture.

(11) The term "processor" means any person who processes a chemical substance or mixture.

(12) The term "standards for the development of test data" means a prescription of-

(A) the-

(i) health and environmental effects, and

(ii) information relating to toxicity, persistence, and other characteristics which affect health and the environment, for which test data for a chemical substance or mixture are to be developed and any analysis that is to be performed on such data, and

(B) to the extent necessary to assure that data respecting such effects and characteristics are reliable and adequate-

(i) the manner in which such data are to be developed,

(ii) the specification of any test protocol or methodology to be employed in the development of such data, and

(iii) such other requirements as are necessary to provide such assurance.

(13) The term "State" means any State of the United States, the District of Columbia, the Commonwealth of Puerto Rico, the Virgin Islands, Guam, the Canal Zone, American Samoa, the Northern Mariana Islands, or any other territory or possession of the United States.

(14) The term "United States", when used in the geographic sense, means all of the States.

Testing of Chemical Substances and Mixtures

[15 U.S.C. 2603]

Sec. 4. (a) Testing requirements. - If the Administrator finds that-

(1)(A) (i) the manufacture, distribution in commerce, processing, use, or disposal of a chemical substance or mixture, or that any combination of such activities, may present an unreasonable risk of injury to health or the environment,

(ii) there are insufficient data and experience upon which the effects of such manufacture, distribution in commerce, processing, use, or disposal of such substance or mixture or of any combination of such activities on health or the environment can reasonably be determined or predicted, and

(iii) testing of such substance or mixture with respect to such effects is necessary to develop such data; or

(B) (i) a chemical substance or mixture is or will be produced in substantial quantities, and (I) it enters or may reasonably be anticipated to enter the environment in substantial quantities or (II) there is or may be significant or substantial human exposure to such substance or mixture,

(ii) there are insufficient data and experience upon which the effects of the manufacture, distribution in commerce, processing, use, or disposal of such substance or mixture or of any combination of such activities on health or the environment can reasonably be determined or predicted, and

(iii) testing of such substance or mixture with respect to such effects is necessary to develop such data; and

(2) in the case of a mixture, the effects which the mixture's manufacture, distribution in commerce, processing, use, or disposal or any combination of such activities may have on health or the environment may not be reasonably and more efficiently determined or predicted by testing the chemical substances 
which comprise the mixture; the Administrator shall by rule require that testing be conducted on such substance or mixture to develop data with respect to the health and environmental effects for which there is an insufficiency of data and experience and which are relevant to a determination that the manufacture, distribution in commerce, processing, use, or disposal of such substance or mixture, or that any combination of such activities, does or does not present an unreasonable risk of injury to health or the environment.

(b) Testing requirement rule.-

(1) A rule under subsection (a) shall include-

(A) identification of the chemical substance or mixture for which testing is required under the rule,

(B) standards for the development of test data for such substance or mixture, and

(C) with respect to chemical substances which are not new chemical substances and to mixtures, a specification of the period (which period may not be of unreasonable duration) within which the persons required to conduct the testing shall submit to the Administrator data developed in accordance with the standards referred to in subparagraph (B).

In determining the standards and period to be included, pursuant to subparagraphs (B) and (C), in a rule under subsection (a), the Administrator's considerations shall include the relative costs of the various test protocols and methodologies which may be required under the rule and the reasonably foreseeable availability of the facilities and personnel needed to perform the testing required under the rule. Any such rule may require the submission to the Administrator of preliminary data during the period prescribed under subparagraph (C).

(2) (A) The health and environmental effects for which standards for the development of test data may be prescribed include carcinogenesis, mutagenesis, teratogenesis, behavioral disorders, cumulative or synergistic effects, and any other effect which may present an unreasonable risk of injury to health or the environment. The characteristics of chemical substances and mixtures for which such standards may be prescribed include persistence, acute toxicity, subacute toxicity, chronic toxicity, and any other characteristic which may present such a risk. The methodologies that may be prescribed in such standards include epidemiologic studies, serial or hierarchical tests, in vitro tests, and whole animal tests, except that before prescribing epidemiologic studies of employees, the Administrator shall consult with the Director of the National Institute for Occupational Safety and Health.

(B) From time to time, but not less than once each 12 months, the Administrator shall review the adequacy of the standards for development of data prescribed in rules under subsection (a) and shall, if necessary, institute proceedings to make appropriate revisions of such standards.

(3) (A) A rule under subsection (a) respecting a chemical substance or mixture shall require the persons described in subparagraph (B) to conduct tests and submit data to the Administrator on such substance or mixture, except that the Administrator may permit two or more of such persons to designate one such person or a qualified third party to conduct such tests and submit such data on behalf of the persons making the designation.

(B) The following persons shall be required to conduct tests and submit data on a chemical substance or mixture subject to a rule under subsection (a):

(i) Each person who manufactures or intends to manufacture such substance or mixture if the Administrator makes a finding described in subsection (a)(1)(A)(ii) or (a)(1)(B)(ii) with respect to the manufacture of such substance or mixture.

(ii) Each person who processes or intends to process such substance or mixture if the Administrator makes a finding described in subsection $(a)(1)(A)(i i)$ or $(a)(1)(B)$ (ii) with respect to the processing of such substance or mixture.

(iii) Each person who manufactures or processes or intends to manufacture or process such substance or mixture if the Administrator makes a finding described in subsection (a)(1)(A)(ii) or (a)(1)(B)(ii) with respect to the distribution in commerce, use, or disposal of such substance or mixture.

(4) Any rule under subsection (a) requiring the testing of and submission of data for a particular chemical substance or mixture shall expire at the end of the reimbursement period (as defined in subsection (c)(3)(B)) which is applicable to test data for such substance or mixture unless the Administrator repeals the rule before such date; and a rule under subsection (a) requiring the testing of and submission of data for a category of chemical substances or mixtures shall expire with respect to a chemical substance or mixture included in the category at the end of the reimbursement period (as so defined) which is applicable to test 
data for such substance or mixture unless the Administrator before such date repeals the application of the rule to such substance or mixture or repeals the rule.

(5) Rules issued under subsection (a) (and any substantive amendment thereto or repeal thereof) shall be promulgated pursuant to section 553 of title 5, United States Code [5 U.S.C. 553], except that (A) the Administrator shall give interested persons an opportunity for the oral presentation of data, views, or arguments, in addition to an opportunity to make written submissions; (B) a transcript shall be made of any oral presentation; and $(C)$ the Administrator shall make and publish with the rule the findings described in paragraph (1)(A) or (1)(B) of subsection (a) and, in the case of a rule respecting a mixture, the finding described in paragraph (2) of such subsection.

(c) Exemption.-

(1) Any person required by a rule under subsection (a) to conduct tests and submit data on a chemical substance or mixture may apply to the Administrator (in such form and manner as the Administrator shall prescribe) for an exemption from such requirement.

(2) If, upon receipt of an application under paragraph (1), the Administrator determines that-

(A) the chemical substance or mixture with respect to which such application was submitted is equivalent to a chemical substance or mixture for which data has been submitted to the Administrator in accordance with a rule under subsection (a) or for which data is being developed pursuant to such a rule, and

(B) submission of data by the applicant on such substance or mixture would be duplicative of data which has been submitted to the Administrator in accordance with such rule or which is being developed pursuant to such rule, the Administrator shall exempt, in accordance with paragraph (3) or (4), the applicant from conducting tests and submitting data on such substance or mixture under the rule with respect to which such application was submitted.

(3) (A) If the exemption under paragraph (2) of any person from the requirement to conduct tests and submit test data on a chemical substance or mixture is granted on the basis of the existence of previously submitted test data and if such exemption is granted during the reimbursement period for such test data (as prescribed by subparagraph (B)), then (unless such person and the persons referred to in clauses (i) and (ii) agree on the amount and method of reimbursement) the Administrator shall order the person granted the exemption to provide fair and equitable reimbursement (in an amount determined under rules of the Administrator)-

(i) to the person who previously submitted such test data, for a portion of the costs incurred by such person in complying with the requirement to submit such data, and

(ii) to any other person who has been required under this subparagraph to contribute with respect to such costs, for a portion of the amount such person was required to contribute.

In promulgating rules for the determination of fair and equitable reimbursement to the persons described in clauses (i) and (ii) for costs incurred with respect to a chemical substance or mixture, the Administrator shall, after consultation with the Attorney General and the Federal Trade Commission, consider all relevant factors, including the effect on the competitive position of the person required to provide reimbursement in relation to the person to be reimbursed and the share of the market for such substance or mixture of the person required to provide reimbursement in relation to the share of such market of the persons to be reimbursed. An order under this subparagraph shall, for purposes of judicial review, be considered final agency action.

(B) For purposes of subparagraph (A), the reimbursement period for any test data for a chemical substance or mixture is a period-

(i) beginning on the date such data is submitted in accordance with a rule promulgated under subsection (a), and

(ii) ending-

(I) five years after the date referred to in clause (i), or

(II) at the expiration of a period which begins on the date referred to in clause (i) and which is equal to the period which the Administrator determines was necessary to develop such data,

whichever is later.

(4) (A) If the exemption under paragraph (2) of any person from the requirement to conduct tests and submit test data on a chemical substance or mixture is granted on the basis of the fact that test data is being developed by one or more persons pursuant to a rule promulgated under subsection (a), then (unless such person and the persons referred to in clauses (i) and (ii) agree on the amount and method 
of reimbursement) the Administrator shall order the person granted the exemption to provide fair and equitable reimbursement (in an amount determined under rules of the Administrator)-

(i) to each such person who is developing such test data, for a portion of the costs incurred by each such person in complying with such rule, and

(ii) to any other person who has been required under this subparagraph to contribute with respect to the costs of complying with such rule, for a portion of the amount such person was required to contribute.

In promulgating rules for the determination of fair and equitable reimbursement to the persons described in clauses (i) and (ii) for costs incurred with respect to a chemical substance or mixture, the Administrator shall, after consultation with the Attorney General and the Federal Trade Commission, consider the factors described in the second sentence of paragraph (3)(A). An order under this subparagraph shall, for purposes of judicial review, be considered final agency action.

(B) If any exemption is granted under paragraph (2) on the basis of the fact that one or more persons are developing test data pursuant to a rule promulgated under subsection (a) and if after such exemption is granted the Administrator determines that no such person has complied with such rule, the Administrator shall (i) after providing written notice to the person who holds such exemption and an opportunity for a hearing, by order terminate such exemption, and (ii) notify in writing such person of the requirements of the rule with respect to which such exemption was granted.

(d) Notice.-Upon the receipt of any test data pursuant to a rule under subsection (a), the Administrator shall publish a notice of the receipt of such data in the Federal Register within 15 days of its receipt. Subject to section 14 [15 U.S.C. 2613], each such notice shall (1) identify the chemical substance or mixture for which data have been received; (2) list the uses or intended uses of such substance or mixture and the information required by the applicable standards for the development of test data; and (3) describe the nature of the test data developed. Except as otherwise provided in section 14 such data shall be made available by the Administrator for examination by any person.

(e) Priority list.-

(1) (A) There is established a committee to make recommendations to the Administrator respecting the chemical substances and mixtures to which the Administrator should give priority consideration for the promulgation of a rule under subsection (a). In making such a recommendation with respect to any chemical substance or mixture, the committee shall consider all relevant factors, including-

(i) the quantities in which the substance or mixture is or will be manufactured,

(ii) the quantities in which the substance or mixture enters or will enter the environment,

(iii) the number of individuals who are or will be exposed to the substance or mixture in their places of employment and the duration of such exposure,

(iv) the extent to which human beings are or will be exposed to the substance or mixture,

(v) the extent to which the substance or mixture is closely related to a chemical substance or mixture which is known to present an unreasonable risk of injury to health or the environment,

(vi) the existence of data concerning the effects of the substance or mixture on health or the environment,

(vii) the extent to which testing of the substance or mixture may result in the development of data upon which the effects of the substance or mixture on health or the environment can reasonably be determined or predicted, and

(viii) the reasonably foreseeable availability of facilities and personnel for performing testing on the substance or mixture.

The recommendations of the committee shall be in the form of a list of chemical substances and mixtures which shall be set forth, either by individual substance or mixture or by groups of substances or mixtures, in the order in which the committee determines the Administrator should take action under subsection (a) with respect to the substances and mixtures. In establishing such list, the committee shall give priority attention to those chemical substances and mixtures which are known to cause or contribute to or which are suspected of causing or contributing to cancer, gene mutations, or birth defects. The committee shall designate chemical substances and mixtures on the list with respect to which the committee determines the Administrator should, within 12 months of the date on which such substances and mixtures are first designated, initiate a proceeding under subsection (a). The total number of chemical substances and mixtures on the list which are designated under the preceding sentence may not, at any time, exceed 50. 
(B) As soon as practicable but not later than nine months after the effective date of this Act [see effective date note to 15 U.S.C. 2601], the committee shall publish in the Federal Register and transmit to the Administrator the list and designations required by subparagraph (A) together with the reasons for the committee's inclusion of each chemical substance or mixture on the list. At least every six months after the date of the transmission to the Administrator of the list pursuant to the preceding sentence, the committee shall make such revisions in the list as it determines to be necessary and shall transmit them to the Administrator together with the committee's reasons for the revisions. Upon receipt of any such revision, the Administrator shall publish in the Federal Register the list with such revision, the reasons for such revision, and the designations made under subparagraph (A). The Administrator shall provide reasonable opportunity to any interested person to file with the Administrator written comments on the committee's list, any revision of such list by the committee, and designations made by the committee, and shall make such comments available to the public. Within the 12-month period beginning on the date of the first inclusion on the list of a chemical substance or mixture designated by the committee under subparagraph (A) the Administrator shall with respect to such chemical substance or mixture either initiate a rulemaking proceeding under subsection (a) or if such a proceeding is not initiated within such period, publish in the Federal Register the Administrator's reason for not initiating such a proceeding.

(2)(A) The committee established by paragraph (1)(A) shall consist of eight members as follows:

(i) One member appointed by the Administrator from the Environmental Protection Agency.

(ii) One member appointed by the Secretary of Labor from officers or employees of the Department of Labor engaged in the Secretary's activities under the Occupational Safety and Health Act of 1970.

(iii) One member appointed by the Chairman of the Council on Environmental Quality from the Council or its officers or employees.

(iv) One member appointed by the Director of the National Institute for Occupational Safety and Health from officers or employees of the Institute.

(v) One member appointed by the Director of the National Institute of Environmental Health Sciences from officers or employees of the Institute.

(vi) One member appointed by the Director of the National Cancer Institute from officers or employees of the Institute.

(vii) One member appointed by the Director of the National Science Foundation from officers or employees of the Foundation.

(viii) One member appointed by the Secretary of Commerce from officers or employees of the Department of Commerce.

(B)(i) An appointed member may designate an individual to serve on the committee on the member's behalf. Such a designation may be made only with the approval of the applicable appointing authority and only if the individual is from the entity from which the member was appointed.

(ii) No individual may serve as a member of the committee for more than four years in the aggregate. If any member of the committee leaves the entity from which the member was appointed, such member may not continue as a member of the committee, and the member's position shall be considered to be vacant. A vacancy in the committee shall be filled in the same manner in which the original appointment was made.

(iii) Initial appointments to the committee shall be made not later than the 60th day after the effective date of this Act [see effective date note to 15 U.S.C. 2601]. Not later than the 90th day after such date the members of the committee shall hold a meeting for the selection of a chairperson from among their number.

(C)(i) No member of the committee, or designee of such member, shall accept employment or compensation from any person subject to any requirement of this Act or of any rule promulgated or order issued thereunder, for a period of at least 12 months after termination of service on the committee.

(ii) No person, while serving as a member of the committee, or designee of such member, may own any stocks or bonds, or have any pecuniary interest, of substantial value in any person engaged in the manufacture, processing, or distribution in commerce of any chemical substance or mixture subject to any requirement of this Act or of any rule promulgated or order issued thereunder. 
(iii) The Administrator, acting through attorneys of the Environmental Protection Agency, or the Attorney General may bring an action in the appropriate district court of the United States to restrain any violation of this subparagraph.

(D) The Administrator shall provide the committee such administrative support services as may be necessary to enable the committee to carry out its function under this subsection.

(f) Required actions.-Upon the receipt of-

(1) any test data required to be submitted under this Act, or

(2) any other information available to the Administrator, which indicates to the Administrator that there may be a reasonable basis to conclude that a chemical substance or mixture presents or will present a significant risk of serious or widespread harm to human beings from cancer, gene mutations, or birth defects, the Administrator shall, within the 180-day period beginning on the date of the receipt of such data or information, initiate appropriate action under section 5, 6, or 7 [15 U.S.C. 2604-2606] to prevent or reduce to a sufficient extent such risk or publish in the Federal Register a finding that such risk is not unreasonable. For good cause shown the Administrator may extend such period for an additional period of not more than 90 days. The Administrator shall publish in the Federal Register notice of any such extension and the reasons therefor. A finding by the Administrator that a risk is not unreasonable shall be considered agency action for purposes of judicial review under chapter 7 of title 5, United States Code. This subsection shall not take effect until two years after the effective date of this Act.

(g) Petition for standards for the development of test data. A person intending to manufacture or process a chemical substance for which notice is required under section 5(a) [15 U.S.C. 2604(a)] and who is not required under a rule under subsection (a) to conduct tests and submit data on such substance may petition the Administrator to prescribe standards for the development of test data for such substance. The Administrator shall by order either grant or deny any such petition within 60 days of its receipt. If the petition is granted, the Administrator shall prescribe such standards for such substance within 75 days of the date the petition is granted. If the petition is denied, the Administrator shall publish, subject to section 14 [15 U.S.C. 2613], in the Federal Register the reasons for such denial.

Manufacturing and Processing Notices

[15 U.S.C. 2604]

Sec. 5. (a) In general.-

(1) Except as provided in subsection (h), no person may-

(A) manufacture a new chemical substance on or after the 30th day after the date on which the Administrator first publishes the list required by section 8(b) [15 U.S.C. 2607(b)], or

(B) manufacture or process any chemical substance for a use which the Administrator has determined, in accordance with paragraph (2), is a significant new use, unless such person submits to the Administrator, at least 90 days before such manufacture or processing, a notice, in accordance with subsection (d), of such person's intention to manufacture or process such substance and such person complies with any applicable requirement of subsection (b).

(2) A determination by the Administrator that a use of a chemical substance is a significant new use with respect to which notification is required under paragraph (1) shall be made by a rule promulgated after a consideration of all relevant factors, including-

(A) the projected volume of manufacturing and processing of a chemical substance,

(B) the extent to which a use changes the type or form of exposure of human beings or the environment to a chemical substance,

(C) the extent to which a use increases the magnitude and duration of exposure of human beings or the environment to a chemical substance, and

(D) the reasonably anticipated manner and methods of manufacturing, processing, distribution in commerce, and disposal of a chemical substance.

(b) Submission of test data.-

(1) (A) If (i) a person is required by subsection (a)(1) to submit a notice to the Administrator before beginning the manufacture or processing of a chemical substance, and (ii) such person is required to submit test data for such substance pursuant to a rule promulgated under section 4 [15 U.S.C. 2603] before the submission of such notice, such person shall submit to the Administrator such data in accordance with such rule at the time notice is submitted in accordance with subsection (a)(1).

(B) If- 
(i) a person is required by subsection (a)(1) to submit a notice to the Administrator, and

(ii) such person has been granted an exemption under section 4(c) from the requirements of a rule promulgated under section 4 before the submission of such notice, such person may not, before the expiration of the 90 day period which begins on the date of the submission in accordance with such rule of the test data the submission or development of which was the basis for the exemption, manufacture such substance if such person is subject to subsection (a)(1)(A) or manufacture or process such substance for a significant new use if the person is subject to subsection (a)(1)(B).

(2)(A) If a person-

(i) is required by subsection (a)(1) to submit a notice to the Administrator before beginning the manufacture or processing of a chemical substance listed under paragraph (4), and

(ii) is not required by a rule promulgated under section 4 before the submission of such notice to submit test data for such substance, such person shall submit to the Administrator data prescribed by subparagraph (B) at the time notice is submitted in accordance with subsection (a)(1).

(B) Data submitted pursuant to subparagraph (A) shall be data which the person submitting the data believes show that-

(i) in the case of a substance with respect to which notice is required under subsection (a)(1)(A), the manufacture, processing, distribution in commerce, use, and disposal of the chemical substance or any combination of such activities will not present an unreasonable risk of injury to health or the environment, or

(ii) in the case of a chemical substance with respect to which notice is required under subsection (a)(1)(B), the intended significant new use of the chemical substance will not present an unreasonable risk of injury to health or the environment.

(3) Data submitted under paragraph (1) or (2) shall be made available, subject to section 14 , for examination by interested persons.

(4)(A) (i) The Administrator may, by rule, compile and keep current a list of chemical substances with respect to which the Administrator finds that the manufacture, processing, distribution in commerce, use, or disposal, or any combination of such activities, presents or may present an unreasonable risk of injury to health or the environment.

(ii) In making a finding under clause (i) that the manufacture, processing, distribution in commerce, use, or disposal of a chemical substance or any combination of such activities presents or may present an unreasonable risk of injury to health or the environment, the Administrator shall consider all relevant factors, including-

(I) the effects of the chemical substance on health and the magnitude of human exposure to such substance; and

(II) the effects of the chemical substance on the environment and the magnitude of environmental exposure to such substance.

(B) The Administrator shall, in prescribing a rule under subparagraph (A) which lists any chemical substance, identify those uses, if any, which the Administrator determines, by rule under subsection (a)(2), would constitute a significant new use of such substance.

(C) Any rule under subparagraph (A), and any substantive amendment or repeal of such a rule, shall be promulgated pursuant to the procedures specified in section 553 of title 5 , United States Code [5 U.S.C. 553], except that (i) the Administrator shall give interested persons an opportunity for the oral presentation of data, views, or arguments, in addition to an opportunity to make written submissions, (ii) a transcript shall be kept of any oral presentation, and (iii) the Administrator shall make and publish with the rule the finding described in subparagraph (A).

(c) Extension of notice period.-The Administrator may for good cause extend for additional periods (not to exceed in the aggregate 90 days) the period, prescribed by subsection (a) or (b) before which the manufacturing or processing of a chemical substance subject to such subsection may begin. Subject to section 14, such an extension and the reasons therefor shall be published in the Federal Register and shall constitute a final agency action subject to judicial review.

(d) Content of notice; publications in the Federal Register.-

(1) The notice required by subsection (a) shall include-

(A) insofar as known to the person submitting the notice or insofar as reasonably ascertainable, the information described in subparagraphs (A), (B), (C), (D), (F), and (G) of section 8(a)(2) and 
(B) in such form and manner as the Administrator may prescribe, any test data in the possession or control of the person giving such notice which are related to the effect of any manufacture, processing, distribution in commerce, use, or disposal of such substance or any article containing such substance, or of any combination of such activities, on health or the environment, and

(C) a description of any other data concerning the environmental and health effects of such substance, insofar as known to the person making the notice or insofar as reasonably ascertainable.

Such a notice shall be made available, subject to section 14, for examination by interested persons.

(2) Subject to section 14, not later than five days (excluding Saturdays, Sundays and legal holidays) after the date of the receipt of a notice under subsection (a) or of data under subsection (b), the Administrator shall publish in the Federal Register a notice which-

(A) identifies the chemical substance for which notice or data has been received;

(B) lists the uses or intended uses of such substance; and

(C) in the case of the receipt of data under subsection (b), describes the nature of the tests performed

on such substance and any data which was developed pursuant to subsection (b) or a rule under section 4.

A notice under this paragraph respecting a chemical substance shall identify the chemical substance by generic class unless the Administrator determines that more specific identification is required in the public interest.

(3) At the beginning of each month the Administrator shall publish a list in the Federal Register of (A) each chemical substance for which notice has been received under subsection (a) and for which the notification period prescribed by subsection (a), (b), or (c) has not expired, and (B) each chemical substance for which such notification period has expired since the last publication in the Federal Register of such list.

(e) Regulation pending development of information.-

(1)(A) If the Administrator determines that-

(i) the information available to the Administrator is insufficient to permit a reasoned evaluation of the health and environmental effects of a chemical substance with respect to which notice is required by subsection (a); and

(ii)(I) in the absence of sufficient information to permit the Administrator to make such an evaluation, the manufacture, processing, distribution in commerce, use, or disposal of such substance, or any combination of such activities, may present an unreasonable risk of injury to health or the environment, or

(II) such substance is or will be produced in substantial quantities, and such substance either enters or may reasonably be anticipated to enter the environment in substantial quantities or there is or may be significant or substantial human exposure to the substance, the Administrator may issue a proposed order, to take effect on the expiration of the notification period applicable to the manufacturing or processing of such substance under subsection (a), (b), or (c), to prohibit or limit the manufacture, processing, distribution in commerce, use, or disposal of such substance or to prohibit or limit any combination of such activities.

(B) A proposed order may not be issued under subparagraph (A) respecting a chemical substance (i) later than $\mathbf{4 5}$ days before the expiration of the notification period applicable to the manufacture or processing of such substance under subsection (a), (b), or (c), and (ii) unless the Administrator has, on or before the issuance of the proposed order, notified, in writing, each manufacturer or processor, as the case may be, of such substance of the determination which underlies such order.

(C) If a manufacturer or processor of a chemical substance to be subject to a proposed order issued under subparagraph (A) files with the Administrator (within the 30-day period beginning on the date such manufacturer or processor received the notice required by subparagraph (B)(ii)) objections specifying with particularity the provisions of the order deemed objectionable and stating the grounds therefor, the proposed order shall not take effect.

(2)(A) (i) Except as provided in clause (ii), if with respect to a chemical substance with respect to which notice is required by subsection (a), the Administrator makes the determination described in paragraph (1)(A) and if-

(I) the Administrator does not issue a proposed order under paragraph (1) respecting such substance, or

(II) the Administrator issues such an order respecting such substance but such order does not take effect because objections were filed under paragraph (1)(C) with respect to it, the Administrator, through attorneys of the Environmental Protection Agency, shall apply to the 
United States District Court for the District of Columbia or the United States district court for the judicial district in which the manufacturer or processor, as the case may be, of such substance is found, resides, or transacts business for an injunction to prohibit or limit the manufacture, processing, distribution in commerce, use, or disposal of such substance (or to prohibit or limit any combination of such activities).

(ii) If the Administrator issues a proposed order under paragraph (1)(A) respecting a chemical substance but such order does not take effect because objections have been filed under paragraph (1)(C) with respect to it, the Administrator is not required to apply for an injunction under clause (i) respecting such substance if the Administrator determines, on the basis of such objections, that the determinations under paragraph (1)(A) may not be made.

(B) A district court of the United States which receives an application under subparagraph (A)(i) for an injunction respecting a chemical substance shall issue such injunction if the court finds that-

(i) the information available to the Administrator is insufficient to permit a reasoned evaluation of the health and environmental effects of a chemical substance with respect to which notice is required by subsection (a); and

(ii)(I) in the absence of sufficient information to permit the Administrator to make such an evaluation, the manufacture, processing, distribution in commerce, use, or disposal of such substance, or any combination of such activities, may present an unreasonable risk of injury to health or the environment, or

(II) such substance is or will be produced in substantial quantities, and such substance either enters or may reasonably be anticipated to enter the environment in substantial quantities or there is or may be significant or substantial human exposure to the substance.

(C) Pending the completion of a proceeding for the issuance of an injunction under subparagraph (B) respecting a chemical substance, the court may, upon application of the Administrator made through attorneys of the Environmental Protection Agency, issue a temporary restraining order or a preliminary injunction to prohibit the manufacture, processing, distribution in commerce, use, or disposal of such a substance (or any combination of such activities) if the court finds that the notification period applicable under subsection (a), (b), or (c) to the manufacturing or processing of such substance may expire before such proceeding can be completed.

(D) After the submission to the Administrator of test data sufficient to evaluate the health and environmental effects of a chemical substance subject to an injunction issued under subparagraph (B) and the evaluation of such data by the Administrator, the district court of the United States which issued such injunction shall, upon petition, dissolve the injunction unless the Administrator has initiated a proceeding for the issuance of a rule under section 6(a) [15 U.S.C. 2605(a)] respecting the substance. If such a proceeding has been initiated, such court shall continue the injunction in effect until the effective date of the rule promulgated in such proceeding or, if such proceeding is terminated without the promulgation of a rule, upon the termination of the proceeding, whichever occurs first.

(f) Protection against unreasonable risks.-

(1) If the Administrator finds that there is a reasonable basis to conclude that the manufacture, processing, distribution in commerce, use, or disposal of a chemical substance with respect to which notice is required by subsection (a), or that any combination of such activities, presents or will present an unreasonable risk of injury to health or environment before a rule promulgated under section 6 [15 U.S.C. 2605] can protect against such risk, the Administrator shall, before the expiration of the notification period applicable under subsection (a), (b), or (c) to the manufacturing or processing of such substance, take the action authorized by paragraph (2) or (3) to the extent necessary to protect against such risk.

(2) The Administrator may issue a proposed rule under section 6(a) [15 U.S.C. 2605(a)] to apply to a chemical substance with respect to which a finding was made under paragraph (1)-

(A) a requirement limiting the amount of such substance which may be manufactured, processed, or distributed in commerce,

(B) a requirement described in paragraph (2), (3), (4), (5), (6), or (7) of section 6(a) [15 U.S.C. 2605(a)(2)-(7)], or

(C) any combination of the requirements referred to in subparagraph (B).

Such a proposed rule shall be effective upon its publication in the Federal Register. Section $6(d)(2)(B)$

[15 U.S.C. 2605(d)(2)(B)] shall apply with respect to such rule.

(3)(A) The Administrator may- 
(i) issue a proposed order to prohibit the manufacture, processing, or distribution in commerce of a substance with respect to which a finding was made under paragraph (1), or

(ii) apply, through attorneys of the Environmental Protection Agency, to the United States District Court for the District of Columbia or the United States district court for the judicial district in which the manufacturer, or processor, as the case may be, of such substance, is found, resides, or transacts business for an injunction to prohibit the manufacture, processing, or distribution in commerce of such substance.

A proposed order issued under clause (i) respecting a chemical substance shall take effect on the expiration of the notification period applicable under subsection (a), (b), or (c) to the manufacture or processing of such substance.

(B) If the district court of the United States to which an application has been made under subparagraph (A)(ii) finds that there is a reasonable basis to conclude that the manufacture, processing, distribution in commerce, use, or disposal of the chemical substance with respect to which such application was made, or that any combination of such activities, presents or will present an unreasonable risk of injury to health or the environment before a rule promulgated under section 6 [15 U.S.C. 2605] can protect against such risk, the court shall issue an injunction to prohibit the manufacture, processing, or distribution in commerce of such substance or to prohibit any combination of such activities.

(C) The provisions of subparagraphs (B) and (C) of subsection (e)(1) shall apply with respect to an order issued under clause (i) of subparagraph (A); and the provisions of subparagraph (C) of subsection (e)(2) shall apply with respect to an injunction issued under subparagraph (B).

(D) If the Administrator issues an order pursuant to subparagraph (A)(i) respecting a chemical substance and objections are filed in accordance with subsection $(e)(1)(C)$, the Administrator shall seek an injunction under subparagraph (A)(ii) respecting such substance unless the Administrator determines, on the basis of such objections, that such substance does not or will not present an unreasonable risk of injury to health or the environment.

(g) Statement of reasons for not taking action. If the Administrator has not initiated any action under this section or section 6 or 7 [15 U.S.C. 2605, 2606] to prohibit or limit the manufacture, processing, distribution in commerce, use, or disposal of a chemical substance, with respect to which notification or data is required by subsection (a)(1)(B) or (b), before the expiration of the notification period applicable to the manufacturing or processing of such substance, the Administrator shall publish a statement of the Administrator's reasons for not initiating such action. Such a statement shall be published in the Federal Register before the expiration of such period. Publication of such statement in accordance with the preceding sentence is not a prerequisite to the manufacturing or processing of the substance with respect to which the statement is to be published.

(h) Exemptions.-

(1) The Administrator may, upon application, exempt any person from any requirement of subsection (a) or (b) to permit such person to manufacture or process a chemical substance for test marketing purposes-

(A) upon a showing by such person satisfactory to the Administrator that the manufacture, processing, distribution in commerce, use, and disposal of such substance, and that any combination of such activities, for such purposes will not present any unreasonable risk of injury to health or the environment, and

(B) under such restrictions as the Administrator considers appropriate.

(2) (A) The Administrator may, upon application, exempt any person from the requirement of subsection (b)(2) to submit data for a chemical substance. If, upon receipt of an application under the preceding sentence, the Administrator determines that-

(i) the chemical substance with respect to which such application was submitted is equivalent to a chemical substance for which data has been submitted to the Administrator as required by subsection (b)(2), and

(ii) submission of data by the applicant on such substance would be duplicative of data which has been submitted to the Administrator in accordance with such subsection, the Administrator shall exempt the applicant from the requirement to submit such data on such substance. No exemption which is granted under this subparagraph with respect to the submission of data for a chemical substance may take effect before the beginning of the reimbursement period applicable to such data.

(B) If the Administrator exempts any person, under subparagraph (A), from submitting data required under subsection (b)(2) for a chemical substance because of the existence of previously submitted data 
and if such exemption is granted during the reimbursement period for such data, then (unless such person and the persons referred to in clauses (i) and (ii) agree on the amount and method of reimbursement) the Administrator shall order the person granted the exemption to provide fair and equitable reimbursement (in an amount determined under rules of the Administrator)-

(i) to the person who previously submitted the data on which the exemption was based, for a portion

of the costs incurred by such person in complying with the requirement under subsection (b)(2) to submit such data, and

(ii) to any other person who has been required under this subparagraph to contribute with respect to such costs, for a portion of the amount such person was required to contribute.

In promulgating rules for the determination of fair and equitable reimbursement to the persons described in clauses (i) and (ii) for costs incurred with respect to a chemical substance, the Administrator shall, after consultation with the Attorney General and the Federal Trade Commission, consider all relevant factors, including the effect on the competitive position of the person required to provide reimbursement in relation to the persons to be reimbursed and the share of the market for such substance of the person required to provide reimbursement in relation to the share of such market of the persons to be reimbursed. For purposes of judicial review, an order under this subparagraph shall be considered final agency action.

(C) For purposes of this paragraph, the reimbursement period for any previously submitted data for a chemical substance is a period-

(i) beginning on the date of the termination of the prohibition, imposed under this section, on the manufacture or processing of such substance by the person who submitted such data to the Administrator, and

(ii) ending-

(I) five years after the date referred to in clause (i), or

(II) at the expiration of a period which begins on the date referred to in clause (i) and is equal to the period which the Administrator determines was necessary to develop such data, whichever is later.

(3) The requirements of subsections (a) and (b) do not apply with respect to the manufacturing or processing of any chemical substance which is manufactured or processed, or proposed to be manufactured or processed, only in small quantities (as defined by the Administrator by rule) solely for purposes of -

(A) scientific experimentation or analysis, or

(B) chemical research on, or analysis of such substance or another substance, including such research or analysis for the development of a product, if all persons engaged in such experimentation, research, or analysis for a manufacturer or processor are notified (in such form and manner as the Administrator may prescribe) of any risk to health which the manufacturer, processor, or the Administrator has reason to believe may be associated with such chemical substance.

(4) The Administrator may, upon application and by rule, exempt the manufacturer of any new chemical substance from all or part of the requirements of this section if the Administrator determines that the manufacture, processing, distribution in commerce, use, or disposal of such chemical substance, or that any combination of such activities, will not present an unreasonable risk of injury to health or the environment. A rule promulgated under this paragraph (and any substantive amendment to, or repeal of, such a rule) shall be promulgated in accordance with paragraphs (2) and (3) of section 6(c).

(5) The Administrator may, upon application, make the requirements of subsections (a) and (b) inapplicable with respect to the manufacturing or processing of any chemical substance $(A)$ which exists temporarily as a result of a chemical reaction in the manufacturing or processing of a mixture or another chemical substance, and (B) to which there is no, and will not be, human or environmental exposure.

(6) Immediately upon receipt of an application under paragraph (1) or (5) the Administrator shall publish in the Federal Register notice of the receipt of such application. The Administrator shall give interested persons an opportunity to comment upon any such application and shall, within 45 days of its receipt, either approve or deny the application. The Administrator shall publish in the Federal Register notice of the approval or denial of such an application.

(i) Definition.-For purposes of this section, the terms "manufacture" and "process" mean manufacturing or processing for commercial purposes. 
[15 U.S.C. 2605]

Sec. 6. (a) Scope of regulation.-If the Administrator finds that there is a reasonable basis to conclude that the manufacture, processing, distribution in commerce, use, or disposal of a chemical substance or mixture, or that any combination of such activities, presents or will present an unreasonable risk of injury to health or the environment, the Administrator shall by rule apply one or more of the following requirements to such substance or mixture to the extent necessary to protect adequately against such risk using the least burdensome requirements:

(1) A requirement-

(A) prohibiting the manufacturing, processing, or distribution in commerce of such substance or mixture, or

(B) limiting the amount of such substance or mixture which may be manufactured, processed, or distributed in commerce.

(2) A requirement-

(A) prohibiting the manufacture, processing, or distribution in commerce of such substance or mixture for (i) a particular use or (ii) a particular use in a concentration in excess of a level specified by the Administrator in the rule imposing the requirement, or

(B) limiting the amount of such substance or mixture which may be manufactured, processed, or distributed in commerce for (i) a particular use or (ii) a particular use in a concentration in excess of a level specified by the Administrator in the rule imposing the requirement.

(3) A requirement that such substance or mixture or any article containing such substance or mixture be marked with or accompanied by clear and adequate warnings and instructions with respect to its use, distribution in commerce, or disposal or with respect to any combination of such activities. The form and content of such warnings and instructions shall be prescribed by the Administrator.

(4) A requirement that manufacturers and processors of such substance or mixture make and retain records of the processes used to manufacture or process such substance or mixture and monitor or conduct tests which are reasonable and necessary to assure compliance with the requirements of any rule applicable under this subsection.

(5) A requirement prohibiting or otherwise regulating any manner or method of commercial use of such substance or mixture.

(6) (A) A requirement prohibiting or otherwise regulating any manner or method of disposal of such substance or mixture, or of any article containing such substance or mixture, by its manufacturer or processor or by any other person who uses, or disposes of, it for commercial purposes.

(B) A requirement under subparagraph (A) may not require any person to take any action which would be in violation of any law or requirement of, or in effect for, a State or political subdivision, and shall require each person subject to it to notify each State and political subdivision in which a required disposal may occur of such disposal.

(7) A requirement directing manufacturers or processors of such substance or mixture (A) to give notice of such unreasonable risk of injury to distributors in commerce of such substance or mixture and, to the extent reasonably ascertainable, to other persons in possession of such substance or mixture or exposed to such substance or mixture, (B) to give public notice of such risk of injury, and (C) to replace or repurchase such substance or mixture as elected by the person to which the requirement is directed.

Any requirement (or combination of requirements) imposed under this subsection may be limited in application to specified geographic areas.

(b) Quality control.-If the Administrator has a reasonable basis to conclude that a particular manufacturer or processor is manufacturing or processing a chemical substance or mixture in a manner which unintentionally causes the chemical substance or mixture to present or which will cause it to present an unreasonable risk of injury to health or the environment-

(1) the Administrator may by order require such manufacturer or processor to submit a description of the relevant quality control procedures followed in the manufacturing or processing of such chemical substance or mixture; and

(2) if the Administrator determines- 
(A) that such quality control procedures are inadequate to prevent the chemical substance or mixture from presenting such risk of injury, the Administrator may order the manufacturer or processor to revise such quality control procedures to the extent necessary to remedy such inadequacy; or

(B) that the use of such quality control procedures has resulted in the distribution in commerce of chemical substances or mixtures which present an unreasonable risk of injury to health or the environment, the Administrator may order the manufacturer or processor to (i) give notice of such risk to processors or distributors in commerce of any such substance or mixture, or to both, and, to the extent reasonably ascertainable, to any other person in possession of or exposed to any such substance, (ii) to give public notice of such risk, and (iii) to provide such replacement or repurchase of any such substance or mixture as is necessary to adequately protect health or the environment.

A determination under subparagraph (A) or (B) of paragraph (2) shall be made on the record after opportunity for hearing in accordance with section 554 of title 5, United States Code [5 U.S.C. 554]. Any manufacturer or processor subject to a requirement to replace or repurchase a chemical substance or mixture may elect either to replace or repurchase the substance or mixture and shall take either such action in the manner prescribed by the Administrator.

(c) Promulgation of subsection (a) rules.-

(1) In promulgating any rule under subsection (a) with respect to a chemical substance or mixture, the Administrator shall consider and publish a statement with respect to-

(A) the effects of such substance or mixture on health and the magnitude of the exposure of human beings to such substance or mixture,

(B) the effects of such substance or mixture on the environment and the magnitude of the exposure of the environment to such substance or mixture,

(C) the benefits of such substance or mixture for various uses and the availability of substitutes for such uses, and

(D) the reasonably ascertainable economic consequences of the rule, after consideration of the effect on the national economy, small business, technological innovation, the environment, and public health.

If the Administrator determines that a risk of injury to health or the environment could be eliminated or reduced to a sufficient extent by actions taken under another Federal law (or laws) administered in whole or in part by the Administrator, the Administrator may not promulgate a rule under subsection (a) to protect against such risk of injury unless the Administrator finds, in the Administrator's discretion, that it is in the public interest to protect against such risk under this Act. In making such a finding the Administrator shall consider (i) all relevant aspects of the risk, as determined by the Administrator in the Administrator's discretion, (ii) a comparison of the estimated costs of complying with actions taken under this Act and under such law (or laws), and (iii) the relative efficiency of actions under this Act and under such law (or laws) to protect against such risk of injury.

(2) When prescribing a rule under subsection (a) the Administrator shall proceed in accordance with section 553 of title 5, United States Code [5 U.S.C. 553] (without regard to any reference in such section to sections 556 and 557 of such title [5 U.S.C. 556, 557]), and shall also (A) publish a notice of proposed rulemaking stating with particularity the reason for the proposed rule; (B) allow interested persons to submit written data, views, and arguments, and make all such submissions publicly available; (C) provide an opportunity for an informal hearing in accordance with paragraph (3); (D) promulgate, if appropriate, a final rule based on the matter in the rulemaking record (as defined in section 19(a) [15 U.S.C. 2618(a)]), and (E) make and publish with the rule the finding described in subsection (a).

(3) Informal hearings required by paragraph (2)(C) shall be conducted by the Administrator in accordance with the following requirements:

(A) Subject to subparagraph (B), an interested person is entitled-

(i) to present such person's position orally or by documentary submissions (or both), and

(ii) if the Administrator determines that there are disputed issues of material fact it is necessary to resolve, to present such rebuttal submissions and to conduct (or have conducted under subparagraph (B)(ii)) such cross-examination of persons as the Administrator determines (I) to be appropriate, and (II) to be required for a full and true disclosure with respect to such issues.

(B) The Administrator may prescribe such rules and make such rulings concerning procedures in such hearings to avoid unnecessary costs or delay. Such rules or rulings may include (i) the imposition of reasonable time limits on each interested person's oral presentations, and (ii) requirements that any cross-examination to which a person may be entitled under subparagraph (A) be conducted by the 
Administrator on behalf of that person in such manner as the Administrator determines (I) to be appropriate, and (II) to be required for a full and true disclosure with respect to disputed issues of material fact.

(C)(i) Except as provided in clause (ii), if a group of persons each of whom under subparagraphs (A) and (B) would be entitled to conduct (or have conducted) cross-examination and who are determined by the Administrator to have the same or similar interests in the proceeding cannot agree upon a single representative of such interests for purposes of cross-examination, the Administrator may make rules and rulings (I) limiting the representation of such interest for such purposes, and (II) governing the manner in which such cross-examination shall be limited.

(ii) When any person who is a member of a group with respect to which the Administrator has made a determination under clause (i) is unable to agree upon group representation with the other members of the group, then such person shall not be denied under the authority of clause (i) the opportunity to conduct (or have conducted) cross-examination as to issues affecting the person's particular interests if (I) the person satisfies the Administrator that the person has made a reasonable and good faith effort to reach agreement upon group representation with the other members of the group and (II) the Administrator determines that there are substantial and relevant issues which are not adequately presented by the group representative.

(D) A verbatim transcript shall be taken of any oral presentation made, and cross-examination conducted in any informal hearing under this subsection. Such transcript shall be available to the public.

(4) (A) The Administrator may, pursuant to rules prescribed by the Administrator, provide compensation for reasonable attorneys' fees, expert witness fees, and other costs of participating in a rulemaking proceeding for the promulgation of a rule under subsection (a) to any person-

(i) who represents an interest which would substantially contribute to a fair determination of the issues to be resolved in the proceeding, and

(ii) if-

(I) the economic interest of such person is small in comparison to the costs of effective participation in the proceeding by such person, or

(II) such person demonstrates to the satisfaction of the Administrator that such person does not have sufficient resources adequately to participate in the proceeding without compensation under this subparagraph.

In determining for purposes of clause (i) if an interest will substantially contribute to a fair determination of the issues to be resolved in a proceeding, the Administrator shall take into account the number and complexity of such issues and the extent to which representation of such interest will contribute to widespread public participation in the proceeding and representation of a fair balance of interests for the resolution of such issues.

(B) In determining whether compensation should be provided to a person under subparagraph (A) and the amount of such compensation, the Administrator shall take into account the financial burden which will be incurred by such person in participating in the rulemaking proceeding. The Administrator shall take such action as may be necessary to ensure that the aggregate amount of compensation paid under this paragraph in any fiscal year to all persons who, in rulemaking proceedings in which they receive compensation, are persons who either-

(i) would be regulated by the proposed rule, or

(ii) represent persons who would be so regulated, may not exceed 25 per centum of the aggregate amount paid as compensation under this paragraph to all persons in such fiscal year.

(5) Paragraph (1), (2), (3), and (4) of this subsection apply to the promulgation of a rule repealing, or making a substantive amendment to, a rule promulgated under subsection (a).

(d) Effective date.-

(1) The Administrator shall specify in any rule under subsection (a) the date on which it shall take effect, which date shall be as soon as feasible.

(2) (A) The Administrator may declare a proposed rule under subsection (a) to be effective upon its publication in the Federal Register and until the effective date of final action taken, in accordance with subparagraph (B), respecting such rule if-

(i) the Administrator determines that-

(I) the manufacture, processing, distribution in commerce, use, or disposal of the chemical substance or mixture subject to such proposed rule or any combination of such activities is 
likely to result in an unreasonable risk of serious or widespread injury to health or the environment before such effective date; and

(II) making such proposed rule so effective is necessary to protect the public interest; and (ii) in the case of a proposed rule to prohibit the manufacture, processing, or distribution of a chemical substance or mixture because of the risk determined under clause (i)(I), a court has in an action under section 7 [15 U.S.C. 2606] granted relief with respect to such risk associated with such substance or mixture.

Such a proposed rule which is made so effective shall not, for purposes of judicial review, be considered final agency action.

(B) If the Administrator makes a proposed rule effective upon its publication in the Federal Register, the Administrator shall, as expeditiously as possible, give interested persons prompt notice of such action, provide reasonable opportunity, in accordance with paragraphs (2) and (3) of subsection (c), for a hearing on such rule, and either promulgate such rule (as proposed or with modifications) or revoke it; and if such a hearing is requested, the Administrator shall commence the hearing within five days from the date such request is made unless the Administrator and the person making the request agree upon a later date for the hearing to begin, and after the hearing is concluded the Administrator shall, within ten days of the conclusion of the hearing, either promulgate such rule (as proposed or with modifications) or revoke it.

(e) Polychlorinated biphenyls.-

(1) Within six months after the effective date of this Act [see effective date note to 15 U.S.C. 2601] the Administrator shall promulgate rules to-

(A) prescribe methods for the disposal of polychlorinated biphenyls, and

(B) require polychlorinated biphenyls to be marked with clear and adequate warnings, and instructions with respect to their processing, distribution in commerce, use, or disposal or with respect to any combination of such activities. Requirements prescribed by rules under this paragraph shall be consistent with the requirements of paragraphs (2) and (3).

(2) (A) Except as provided under subparagraph (B), effective one year after the effective date of this Act [see effective date note to 15 U.S.C. 2601] no person may manufacture, process, or distribute in commerce or use any polychlorinated biphenyl in any manner other than in a totally enclosed manner. (B) The Administrator may by rule authorize the manufacture, processing, distribution in commerce or use (or any combination of such activities) of any polychlorinated biphenyl in a manner other than in a totally enclosed manner if the Administrator finds that such manufacture, processing, distribution in commerce, or use (or combination of such activities) will not present an unreasonable risk of injury to health or the environment.

(C) For the purposes of this paragraph, the term "totally enclosed manner" means any manner which will ensure that any exposure of human beings or the environment to a polychlorinated biphenyl will be insignificant as determined by the Administrator by rule.

(3)(A) Except as provided in subparagraphs (B) and (C)-

(i) no person may manufacture any polychlorinated biphenyl after two years after the effective date of this Act [see effective date note to 15 U.S.C. 2601], and

(ii) no person may process or distribute in commerce any polychlorinated biphenyl after two and one-half years after such date [see effective date note to 15 U.S.C. 2601].

(B) Any person may petition the Administrator for an exemption from the requirements of subparagraph (A), and the Administrator may grant by rule such an exemption if the Administrator finds that-

(i) an unreasonable risk of injury to health or environment would not result, and

(ii) good faith efforts have been made to develop a chemical substance which does not present an unreasonable risk of injury to health or the environment and which may be substituted for such polychlorinated biphenyl.

An exemption granted under this subparagraph shall be subject to such terms and conditions as the Administrator may prescribe and shall be in effect for such period (but not more than one year from the date it is granted) as the Administrator may prescribe.

(C) Subparagraph (A) shall not apply to the distribution in commerce of any polychlorinated biphenyl if such polychlorinated biphenyl was sold for purposes other than resale before two and one half years after the date of enactment of this Act [enacted Oct. 11, 1976]. 
(4) Any rule under paragraph (1), (2)(B), or (3)(B) shall be promulgated in accordance with paragraphs (2), (3), and (4) of subsection (c).

(5) This subsection does not limit the authority of the Administrator, under any other provision of this Act or any other Federal law, to take action respecting any polychlorinated biphenyl.

Imminent Hazards

[15 U.S.C. 2606]

Sec. 7. (a) Actions authorized and required.-

(1) The Administrator may commence a civil action in an appropriate district court of the United States-

(A) for seizure of an imminently hazardous chemical substance or mixture or any article containing such a substance or mixture,

(B) for relief (as authorized by subsection (b)) against any person who manufactures, processes, distributes in commerce, or uses, or disposes of, an imminently hazardous chemical substance or mixture or any article containing such a substance or mixture, or

(C) for both such seizure and relief.

A civil action may be commenced under this paragraph notwithstanding the existence of a rule under section $4,5,6$, or title IV [15 U.S.C. 2603-2605] or an order under section 5 or title IV [15 U.S.C. 2604], and notwithstanding the pendency of any administrative or judicial proceeding under any provision of this Act. (2) If the Administrator has not made a rule under section 6(a) [15 U.S.C. 2605(a)] immediately effective (as authorized by subsection 6(d)(2)(A)(i) [15 U.S.C. 2605(d)(2)(A)(i)]) with respect to an imminently hazardous chemical substance or mixture, the Administrator shall commence in a district court of the United States with respect to such substance or mixture or article containing such substance or mixture a civil action described in subparagraph (A), (B), or (C) of paragraph (1).

(b) Relief authorized.-

(1) The district court of the United States in which an action under subsection (a) is brought shall have jurisdiction to grant such temporary or permanent relief as may be necessary to protect health or the environment from the unreasonable risk associated with the chemical substance, mixture, or article involved in such action.

(2) In the case of an action under subsection (a) brought against a person who manufactures, processes, or distributes in commerce a chemical substance or mixture or an article containing a chemical substance or mixture, the relief authorized by paragraph (1) may include the issuance of a mandatory order requiring (A) in the case of purchasers of such substance, mixture, or article known to the defendant, notification to such purchasers of the risk associated with it; (B) public notice of such risk; (C) recall; (D) the replacement or repurchase of such substance, mixture, or article; or $(E)$ any combination of the actions described in the preceding clauses.

(3) In the case of an action under subsection (a) against a chemical substance, mixture, or article, such substance, mixture, or article may be proceeded against by process of libel for its seizure and condemnation. Proceedings in such an action shall conform as nearly as possible to proceedings in rem in admiralty.

(c) Venue and consolidation.-

(1) (A) An action under subsection (a) against a person who manufactures, processes, or distributes a chemical substance or mixture or an article containing a chemical substance or mixture may be brought in the United States District Court for the District of Columbia or for any judicial district in which any of the defendants is found, resides, or transacts business; and process in such an action may be served on a defendant in any other district in which such defendant resides or may be found. An action under subsection (a) against a chemical substance, mixture, or article may be brought in any United States district court within the jurisdiction of which the substance, mixture, or article is found.

(B) In determining the judicial district in which an action may be brought under subsection (a) in instances in which such action may be brought in more than one judicial district, the Administrator shall take into account the convenience of the parties.

(C) Subpoenas [Subpoenas] requiring attendance of witnesses in an action brought under subsection (a) may be served in any judicial district.

(2) Whenever proceedings under subsection (a) involving identical chemical substances, mixtures, or articles are pending in courts in two or more judicial districts, they shall be consolidated for trial by order of any such court upon application reasonably made by any party in interest, upon notice to all parties in interest. 
(d) Action under 15 U.S.C. 2605.-Where appropriate, concurrently with the filing of an action under subsection (a) or as soon thereafter as may be practicable, the Administrator shall initiate a proceeding for the promulgation of a rule under section 6(a) [15 U.S.C. 2605(a)].

(e) Representation.-Notwithstanding any other provision of law, in any action under subsection (a), the Administrator may direct attorneys of the Environmental Protection Agency to appear and represent the Administrator in such an action.

(f) Definition.-For the purposes of subsection (a), the term "imminently hazardous chemical substance or mixture" means a chemical substance or mixture which presents an imminent and unreasonable risk of serious or widespread injury to health or the environment. Such a risk to health or the environment shall be considered imminent if it is shown that the manufacture, processing, distribution in commerce, use, or disposal of the chemical substance or mixture, or that any combination of such activities, is likely to result in such injury to health or the environment before a final rule under section 6 [15 U.S.C. 2605] can protect against such risk.

\section{Reporting and Retention of Information}

[15 U.S.C. 2607]

Sec. 8

(a) Reports.-

(1) The Administrator shall promulgate rules under which-

(A) each person (other than a small manufacturer or processor) who manufactures or processes or proposes to manufacture or process a chemical substance (other than a chemical substance described in subparagraph (B)(ii) shall maintain such records, and shall submit to the Administrator such reports, as the Administrator may reasonably require, and

(B) each person (other than a small manufacturer or processor) who manufactures or processes or proposes to manufacture or process-

(i) a mixture, or

(ii) a chemical substance in small quantities (as defined by the Administrator by rule) solely for purposes of scientific experimentation or analysis or chemical research on, or analysis of, such substance or another substance, including any such research or analysis for the development of a product, shall maintain records and submit to the Administrator reports but only to the extent the Administrator determines the maintenance of records or submission of reports, or both, is necessary for the effective enforcement of this Act.

The Administrator may not require in a rule promulgated under this paragraph the maintenance of records or the submission of reports with respect to changes in the proportions of the components of a mixture unless the Administrator finds that the maintenance of such records or the submission of such reports, or both, is necessary for the effective enforcement of this Act. For purposes of the compilation of the list of chemical substances required under subsection (b), the Administrator shall promulgate rules pursuant to this subsection not later than $\mathbf{1 8 0}$ days after the effective date of this Act [see effective date note to 15 U.S.C. 2601].

(2) The Administrator may require under paragraph (1) maintenance of records and reporting with respect to the following insofar as known to the person making the report or insofar as reasonably ascertainable:

(A) The common or trade name, the chemical identity, and the molecular structure of each chemical substance or mixture for which such a report is required.

(B) The categories or proposed categories of use of each such substance or mixture.

(C) The total amount of each such substance and mixture manufactured or processed, reasonable estimates of the total amount to be manufactured or processed, the amount manufactured or processed for each of its categories of use, and reasonable estimates of the amount to be manufactured or processed for each of its categories of use or proposed categories of use.

(D) A description of the byproducts resulting from the manufacture, processing, use, or disposal of each such substance or mixture.

(E) All existing data concerning the environmental and health effects of such substance or mixture.

(F) The number of individuals exposed, and reasonable estimates of the number who will be exposed, to such substance or mixture in their places of employment and the duration of such exposure.

(G) In the initial report under paragraph (1) on such substance or mixture, the manner or method of its disposal, and in any subsequent report on such substance or mixture, any change in such manner or method. 
To the extent feasible, the Administrator shall not require under paragraph (1), any reporting which is unnecessary or duplicative.

(3)(A) (i) The Administrator may by rule require a small manufacturer or processor of a chemical substance to submit to the Administrator such information respecting the chemical substance as the Administrator may require for publication of the first list of chemical substances required by subsection (b).

(ii) The Administrator may by rule require a small manufacturer or processor of a chemical substance or mixture-

(I) subject to a rule proposed or promulgated under section 4, 5(b)(4), or 6 [15 U.S.C. 2603, 2604(b)(4), 2605], or an order in effect under section 5(e) [15 U.S.C. 2604(e)], or

(II) with respect to which relief has been granted pursuant to a civil action brought under section 5 or 7 [15 U.S.C. 2604, 2606], to maintain such records on such substance or mixture, and to submit to the Administrator such reports on such substance or mixture, as the Administrator may reasonably require. A rule under this clause requiring reporting may require reporting with respect to the matters referred to in paragraph (2).

(B) The Administrator, after consultation with the Administrator of the Small Business Administration, shall by rule prescribe standards for determining the manufacturers and processors which qualify as small manufacturers and processors for purposes of this paragraph and paragraph (1).

(b) Inventory.-

(1) The Administrator shall compile, keep current, and publish a list of each chemical substance which is manufactured or processed in the United States. Such list shall at least include each chemical substance which any person reports, under section 5 [15 U.S.C. 2604] or subsection (a) of this section, is manufactured or processed in the United States. Such list may not include any chemical substance which was not manufactured or processed in the United States within three years before the effective date of the rules promulgated pursuant to the last sentence of subsection (a)(1). In the case of a chemical substance for which a notice is submitted in accordance with section 5 [15 U.S.C. 2604], such chemical substance shall be included in such list as of the earliest date (as determined by the Administrator) on which such substance was manufactured or processed in the United States. The Administrator shall first publish such a list not later than 315 days after the effective date of this Act [see effective date note to 15 U.S.C. 2601]. The Administrator shall not include in such list any chemical substance which is manufactured or processed only in small quantities (as defined by the Administrator by rule) solely for purposes of scientific experimentation or analysis or chemical research on, or analysis of, such substance or another substance, including such research or analysis for the development of a product.

(2) To the extent consistent with the purposes of this Act, the Administrator may, in lieu of listing, pursuant to paragraph (1), a chemical substance individually, list a category of chemical substances in which such substance is included.

(c) Records.-Any person who manufactures, processes, or distributes in commerce any chemical substance or mixture shall maintain records of significant adverse reactions to health or the environment, as determined by the Administrator by rule, alleged to have been caused by the substance or mixture. Records of such adverse reactions to the health of employees shall be retained for a period of 30 years from the date such reactions were first reported to or known by the person maintaining such records. Any other record of such adverse reactions shall be retained for a period of five years from the date the information contained in the record was first reported to or known by the person maintaining the record. Records required to be maintained under this subsection shall include records of consumer allegations of personal injury or harm to health, reports of occupational disease or injury, and reports or complaints of injury to the environment submitted to the manufacturer, processor, or distributor in commerce from any source. Upon request of any duly designated representative of the Administrator, each person who is required to maintain records under this subsection shall permit the inspection of such records and shall submit copies of such records.

(d) Health and safety studies. - The Administrator shall promulgate rules under which the Administrator shall require any person who manufactures, processes, or distributes in commerce or who proposes to manufacture, process, or distribute in commerce any chemical substance or mixture (or with respect to paragraph (2), any person who has possession of a study) to submit to the Administrator-

(1) lists of health and safety studies (A) conducted or initiated by or for such person with respect to such substance or mixture at any time, (B) known to such person; or (C) reasonably ascertainable by such person, except that the Administrator may exclude certain types or categories of studies from the requirements of 
this subsection if the Administrator finds that submission of lists of such studies are unnecessary to carry out the purposes of this Act; and

(2) copies of any study contained on a list submitted pursuant to paragraph (1) or otherwise known by such person.

(e) Notice to Administrator of substantial risks.-Any person who manufactures, processes, or distributes in commerce a chemical substance or mixture and who obtains information which reasonably supports the conclusion that such substance or mixture presents a substantial risk of injury to health or the environment shall immediately inform the Administrator of such information unless such person has actual knowledge that the Administrator has been adequately informed of such information.

(f) Definitions. For purposes of this section, the terms "manufacture" and "process" mean manufacture or process for commercial purposes.

Relationship to Other Federal Laws

[15 U.S.C. 2608]

Sec. 9. (a) Laws not administered by the Administrator--

(1) If the Administrator has reasonable basis to conclude that the manufacture, processing, distribution in commerce, use, or disposal of a chemical substance or mixture, or that any combination of such activities, presents or will present an unreasonable risk of injury to health or the environment and determines, in the Administrator's discretion, that such risk may be prevented or reduced to a sufficient extent by action taken under a Federal law not administered by the Administrator, the Administrator shall submit to the agency which administers such law a report which describes such risk and includes in such description a specification of the activity or combination of activities which the Administrator has reason to believe so presents such risk. Such report shall also request such agency-

(A)(i) to determine if the risk described in such report may be prevented or reduced to a sufficient extent by action taken under such law, and

(ii) if the agency determines that such risk may be so prevented or reduced, to issue an order declaring whether or not the activity or combination of activities specified in the description of such risk presents such risk; and

(B) to respond to the Administrator with respect to the matters described in subparagraph (A).

Any report of the Administrator shall include a detailed statement of the information on which it is based and shall be published in the Federal Register. The agency receiving a request under such a report shall make the requested determination, issue the requested order, and make the requested response within such time as the Administrator specifies in the request, but such time specified may not be less than 90 days from the date the request was made. The response of an agency shall be accompanied by a detailed statement of the findings and conclusions of the agency and shall be published in the Federal Register.

(2) If the Administrator makes a report under paragraph (1) with respect to a chemical substance or mixture and the agency to which such report was made either-

(A) issues an order declaring that the activity or combination of activities specified in the description of the risk described in the report does not present the risk described in the report, or

(B) initiates, within 90 days of the publication in the Federal Register of the response of the agency under paragraph (1), action under the law (or laws) administered by such agency to protect against such risk associated with such activity or combination of activities, the Administrator may not take any action under section 6 or 7 with respect to such risk.

(3) If the Administrator has initiated action under section 6 or 7 [15 U.S.C. 2605, 2606] with respect to a risk associated with a chemical substance or mixture which was the subject of a report made to an agency under paragraph (1), such agency shall before taking action under the law (or laws) administered by it to protect against such risk consult with the Administrator for the purpose of avoiding duplication of Federal action against such risk.

(b) Laws administered by the Administrator.-The Administrator shall coordinate actions taken under this Act with actions taken under other Federal "laws administered in whole or in part by the Administrator. If the Administrator determines that a risk to health or the environment associated with a chemical substance or mixture could be eliminated or reduced to a sufficient extent by actions taken under the authorities contained in such other Federal laws, the Administrator shall use such authorities to protect against such risk unless the Administrator determines, in the Administrator's discretion, that it is in the public interest to protect against 
such risk by actions taken under this Act. This subsection shall not be construed to relieve the Administrator of any requirement imposed on the Administrator by such other Federal laws.

(c) Occupational safety and health.-In exercising any authority under this Act, the Administrator shall not, for purposes of section 4(b)(1) of the Occupational Safety and Health Act of 1970 [29 U.S.C. 653(b)(1)], be deemed to be exercising statutory authority to prescribe or enforce standards or regulations affecting occupational safety and health.

(d) Coordination.- In administering this Act, the Administrator shalk consult and coordinate with the Secretary of Health, Education, and Welfare and the heads of any other appropriate Federal executive department or agency, any relevant independent regulatory agency, and any other appropriate instrumentality of the Federal Government for the purpose of achieving the maximum enforcement of this Act while imposing the least burdens of duplicative requirements on those subject to the Act and for other purposes. The Administrator shall, in the report required by section 30 [15 U.S.C. 2629], report annually to the Congress on actions taken to coordinate with such other Federal departments, agencies, or instrumentalities, and on actions taken to coordinate the authority under this Act with the authority granted under other Acts referred to in subsection (b).

\section{Research, Development, Collection, Dissemination, and Utilization of Data}

[15 U.S.C. 2609]

Sec. 10. (a) Authority.-The Administrator shall, in consultation and cooperation with the Secretary of Health, Education, and Welfare and with other heads of appropriate departments and agencies, conduct such research, development, and monitoring as is necessary to carry out the purposes of this Act. The Administrator may enter into contracts and may make grants for research, development, and monitoring under this subsection. Contracts may be entered into under this subsection without regard to sections 3648 and 3709 of the Revised Statutes (31 U.S.C. 529, 14[41] U.S.C. 5) [31 U.S.C. 529; 41 U.S.C. 5].

(b) Data systems.-

(1) The Administrator shall establish, administer, and be responsible for the continuing activities of an interagency committee which shall design, establish, and coordinate an efficient and effective system, within the Environmental Protection Agency, for the collection, dissemination to other Federal departments and agencies, and use of data submitted to the Administrator under this Act.

(2) (A) The Administrator shall, in consultation and cooperation with the Secretary of Health, Education, and Welfare and other heads of appropriate departments and agencies design, establish, and coordinate an efficient and effective system for the retrieval of toxicological and other scientific data which could be useful to the Administrator in carrying out the purposes of this Act. Systematized retrieval shall be developed for use by all Federal and other departments and agencies with responsibilities in the area of regulation or study of chemical substances and mixtures and their effect on health or the environment. (B) The Administrator, in consultation and cooperation with the Secretary of Health, Education, and Welfare, may make grants and enter into contracts for the development of a data retrieval system described in subparagraph (A). Contracts may be entered into under this subparagraph without regard to sections 3648 and 3709 of the Revised Statutes (31 U.S.C. 529, 41 U.S.C. 5) [31 U.S.C. 529; 41 U.S.C. 5].

(c) Screening techniques. - The Administrator shall coordinate, with the Assistant Secretary for Health of the Department of Health, Education, and Welfare, research undertaken by the Administrator and directed toward the development of rapid, reliable, and economical screening techniques for carcinogenic, mutagenic, teratogenic, and ecological effects of chemical substances and mixtures.

(d) Monitoring.-The Administrator shall, in consultation and cooperation with the Secretary of Health, Education, and Welfare, establish and be responsible for research aimed at the development, in cooperation with local, State, and Federal agencies, of monitoring techniques and instruments which may be used in the detection of toxic chemical substances and mixtures and which are reliable, economical, and capable of being implemented under a wide variety of conditions.

(e) Basic research.-The Administrator shall, in consultation and cooperation with the Secretary of Health, Education, and Welfare, establish research programs to develop the fundamental scientific basis of the screening and monitoring techniques described in subsections (c) and (d), the bounds of the reliability of such techniques, and the opportunities for their improvement.

(f) Training.-The Administrator shall establish and promote programs and workshops to train or facilitate the training of Federal laboratory and technical personnel in existing or newly developed screening and monitoring techniques. 
(g) Exchange of research and development results. - The Administrator shall, in consultation with the Secretary of Health, Education, and Welfare and other heads of appropriate departments and agencies, establish and coordinate a system for exchange among Federal, State, and local authorities of research and development results respecting toxic chemical substances and mixtures, including a system to facilitate and promote the development of standard data format and analysis and consistent testing procedures.

Inspections and Subpoenas

[15 U.S.C. 2610]

Sec. 11. (a) In general.-For purposes of administering this Act, the Administrator, and any duly designated representative of the Administrator, may inspect any establishment, facility, or other premises in which chemical substances or mixtures, or products subject to title IV are manufactured, processed, stored, or held before or after their distribution in commerce and any conveyance being used to transport chemical substances, mixtures, such products, or such articles in connection with distribution in commerce. Such an inspection may only be made upon the presentation of appropriate credentials and of a written notice to the owner, operator, or agent in charge of the premises or conveyance to be inspected. A separate notice shall be given for each such inspection, but a notice shall not be required for each entry made during the period covered by the inspection. Each such inspection shall be commenced and completed with reasonable promptness and shall be conducted at reasonable times, within reasonable limits, and in a reasonable manner.

(b) Scope.-

(1) Except as provided in paragraph (2), an inspection conducted under subsection (a) shall extend to all things within the premises or conveyance inspected (including records, files, papers, processes, controls, and facilities) bearing on whether the requirements of this Act applicable to the chemical substances, mixtures, or products subject to title IV within such premises or conveyance have been complied with.

(2) No inspection under subsection (a) shall extend to-

(A) financial data,

(B) sales data (other than shipment data),

(C) pricing data,

(D) personnel data, or

(E) research data (other than data required by this Act or under a rule promulgated thereunder), unless the nature and extent of such data are described with reasonable specificity in the written notice required by subsection (a) for such inspection.

(c) Subpoenas.-In carrying out this Act, the Administrator may by subpoena require the attendance and testimony of witnesses and the production of reports, papers, documents, answers to questions, and other information that the Administrator deems necessary. Witnesses shall be paid the same fees and mileage that are paid witnesses in the courts of the United States. In the event of contumacy, failure, or refusal of any person to obey any such subpoena, any district court of the United States in which venue is proper shall have jurisdiction to order any such person to comply with such subpoena. Any failure to obey such an order of the court is punishable by the court as a contempt thereof.

\section{Exports}

[15 U.S.C. 2611]

Sec. 12. (a) In general.-

(1) Except as provided in paragraph (2) and subsection (b), this Act (other than section 8 [15 U.S.C. 2607]) shall not apply to any chemical substance, mixture, or to an article containing a chemical substance or mixture, if-

(A) it can be shown that such substance, mixture, or article is being manufactured, processed, or distributed in commerce for export from the United States, unless such substance, mixture, or article was, in fact, manufactured, processed, or distributed in commerce, for use in the United States, and (B) such substance, mixture, or article (when distributed in commerce), or any container in which it is enclosed (when so distributed), bears a stamp or label stating that such substance, mixture, or article is intended for export. 
(2) Paragraph (1) shall not apply to any chemical substance, mixture, or article if the Administrator finds that the substance, mixture, or article will present an unreasonable risk of injury to health within the United States or to the environment of the United States. The Administrator may require, under section 4 [15 U.S.C. 2603], testing of any chemical substance or mixture exempted from this Act by paragraph (1) for the purpose of determining whether or not such substance or mixture presents an unreasonable risk of injury to health within the United States or to the environment of the United States.

(b) Notice.-

(1) If any person exports or intends to export to a foreign country a chemical substance or mixture for which the submission of data is required under section 4 or 5(b) [15 U.S.C. 2603,2604 (b)], such person shall notify the Administrator of such exportation or intent to export and the Administrator shall furnish to the government of such country notice of the availability of the data submitted to the Administrator under such section for such substance or mixture.

(2) If any person exports or intends to export to a foreign country a chemical substance or mixture for which an order has been issued under section 5 [15 U.S.C. 2604] or a rule has been proposed or promulgated under section 5 or 6 [15 U.S.C. 2604, 2605], or with respect to which an action is pending, or relief has been granted under section 5 or 7 [15 U.S.C. 2604, 2606], such person shall notify the Administrator of such exportation or intent to export and the Administrator shall furnish to the government of such country notice of such rule, order, action, or relief.

\section{Entry into Customs Territory of the United States}

[15 U.S.C. 2612]

Sec. 13. (a) In general.-

(1) The Secretary of the Treasury shall refuse entry into the customs territory of the United States (as defined in general note 2 of the Harmonized Tariff Schedule of the United States [19 U.S.C. 1202]) of any chemical substance, mixture, or article containing a chemical substance or mixture offered for such entry if-

(A) it fails to comply with any rule in effect under this Act [15 U.S.C. 2601 et seq.], or

(B) it is offered for entry in violation of section 5, 6, or title IV [15 U.S.C. 2604, 2605], a rule or order under section 5, 6, or title IV [15 U.S.C. 2604, 2605], or an order issued in a civil action brought under section 5,7 or title IV [15 U.S.C. 2604, 2606].

(2) If a chemical substance, mixture, or article is refused entry under paragraph (1), the Secretary of the Treasury shall notify the consignee of such entry refusal, shall not release it to the consignee, and shall cause its disposal or storage (under such rules as the Secretary of the Treasury may prescribe) if it has not been exported by the consignee within 90 days from the date of receipt of notice of such refusal, except that the Secretary of the Treasury may, pending a review by the Administrator of the entry refusal, release to the consignee such substance, mixture, or article on execution of bond for the amount of the full invoice of such substance, mixture, or article (as such value is set forth in the customs entry), together with the duty thereon. On failure to return such substance, mixture, or article for any cause to the custody of the Secretary of the Treasury when demanded, such consignee shall be liable to the United States for liquidated damages equal to the full amount of such bond. All charges for storage, cartage, and labor on and for disposal of substances, mixtures, or articles which are refused entry or release under this section shall be paid by the owner or consignee, and in default of such payment shall constitute a lien against any future entry made by such owner or consignee.

(b) Rules.-The Secretary of the Treasury, after consultation with the Administrator, shall issue rules for the administration of subsection (a) of this section.

\section{Disclosure of Data}

[15 U.S.C. 2613]

Sec. 14. (a) In general.-Except as provided by subsection (b), any information reported to, or otherwise obtained by, the Administrator (or any representative of the Administrator) under this Act, which is exempt from disclosure pursuant to subsection (a) of section 552 of title 5, United States Code [5 U.S.C. 552(a)], by reason of subsection (b)(4) of such section [5 U.S.C. 552(b)(4)], shall, notwithstanding the provisions of any other section of this Act, not be disclosed by the Administrator or by any officer or employee of the United States, except that such information-

(1) shall be disclosed to any officer or employee of the United States- 
(A) in connection with the official duties of such officer or employee under any law for the protection of health or the environment, or

(B) for specific law enforcement purposes;

(2) shall be disclosed to contractors with the United States and employees of such contractors if in the opinion of the Administrator such disclosure is necessary for the satisfactory performance by the contractor of a contract with the United States entered into on or after the date of enactment of this Act [enacted Oct. 11, 1976] for the performance of work in connection with this Act and under such conditions as the Administrator may specify;

(3) shall be disclosed if the Administrator determines it necessary to protect health or the environment against an unreasonable risk of injury to health or the environment; or

(4) may be disclosed when relevant in any proceeding under this Act, except that disclosure in such a proceeding shall be made in such manner as to preserve confidentiality to the extent practicable without impairing the proceeding.

In any proceeding under section 552(a) of title 5, United States Code [5 U.S.C. 552(a)], to obtain information the disclosure of which has been denied because of the provisions of this subsection, the Administrator may not rely on section 552(b)(3) [5 U.S.C. 552(b)(3)] of such title to sustain the Administrator's action.

(b) Data from health and safety studies.-

(1) Subsection (a) does not prohibit the disclosure of-

(A) any health and safety study which is submitted under this Act with respect to-

(i) any chemical substance or mixture which, on the date on which such study is to be disclosed has been offered for commercial distribution, or

(ii) any chemical substance or mixture for which testing is required under section 4 [15 U.S.C. 2603] or for which notification is required under section 5 [15 U.S.C. 2604], and

(B) any data reported to, or otherwise obtained by, the Administrator from a health and safety study which relates to a chemical substance or mixture described in clause (i) or (ii) of subparagraph (A).

This paragraph does not authorize the release of any data which discloses processes used in the manufacturing or processing of a chemical substance or mixture or, in the case of a mixture, the release of data disclosing the portion of the mixture comprised by any of the chemical substances in the mixture.

(2) If a request is made to the Administrator under subsection (a) of section 552 of title 5, United States Code [5 U.S.C. 552(a)], for information which is described in the first sentence of paragraph (1) and which is not information described in the second sentence of such paragraph, the Administrator may not deny such request on the basis of subsection (b)(4), of such section [5 U.S.C. 552(b)(4)].

(c) Designation and release of confidential data.-

(1) In submitting data under this Act, a manufacturer, processor, or distributor in commerce may (A) designate the data which such person believes is entitled to confidential treatment under subsection (a), and (B) submit such designated data separately from other data submitted under this Act. A designation under this paragraph shall be made in writing and in such manner as the Administrator may prescribe.

(2) (A) Except as provided by subparagraph (B), if the Administrator proposes to release for inspection data which has been designated under paragraph (1)(A), the Administrator shall notify, in writing and by certified mail, the manufacturer, processor, or distributor in commerce who submitted such data of the intent to release such data. If the release of such data is to be made pursuant to a request made under section 552(a) of title 5, United States Code [5 U.S.C. 552(a)], such notice shall be given immediately upon approval of such request by the Administrator. The Administrator may not release such data until the expiration of 30 days after the manufacturer, processor, or distributor in commerce submitting such data has received the notice required by this subparagraph.

(B) (i) Subparagraph (A) shall not apply to the release of information under paragraph (1), (2), (3), or (4) of subsection (a), except that the Administrator may not release data under paragraph (3) of subsection (a) unless the Administrator has notified each manufacturer, processor, and distributor in commerce who submitted such data of such release. Such notice shall be made in writing by certified mail at least 15 days before the release of such data, except that if the Administrator determines that the release of such data is necessary to protect against an imminent, unreasonable risk of injury to health or the environment, such notice may be made by such means as the Administrator determines will provide notice at least 24 hours before such release is made.

(ii) Subparagraph (A) shall not apply to the release of information described in subsection (b)(1) other than information described in the second sentence of such subsection. 
(d) Criminal penalty for wrongful disclosure.-

(1) Any officer or employee of the United States or former officer or employee of the United States, who by virtue of such employment or official position has obtained possession of, or has access to, material the disclosure of which is prohibited by subsection (a), and who knowing that disclosure of such material is prohibited by such subsection, willfully discloses the material in any manner to any person not entitled to receive it, shall be guilty of a misdemeanor and fined not more than $\$ 5,000$ or imprisoned for not more than one year, or both. Section 1905 of title 18, United States Code [18 U.S.C. 1905], does not apply with respect to the publishing, divulging, disclosure, or making known of, or making available, information reported or otherwise obtained under this Act.

(2) For the purposes of paragraph (1), any contractor with the United States who is furnished information as authorized by subsection (a)(2), and any employee of any such contractor, shall be considered to be an employee of the United States.

(e) Access by Congress.-Notwithstanding any limitation contained in this section or any other provision of law, all information reported to or otherwise obtained by the Administrator (or any representative of the Administrator) under this Act shall be made available, upon written request of any duly authorized committee of the Congress, to such committee.

\section{Prohibited Acts}

[15 U.S.C. 2614]

Sec. 15. It shall be unlawful for any person to-

(1) fail or refuse to comply with (A) any rule promulgated or order issued under section 4 [15 U.S.C. 2603], (B) any requirement prescribed by section 5 or 6 [15 U.S.C. 2604, 2605], (C) any rule promulgated or order issued under section 5 or 6 [15 U.S.C. 2604, 2605], or (D) any requirement of title II or any rule promulgated or order issued under title II;

(2) use for commercial purposes a chemical substance or mixture which such person knew or had reason to know was manufactured, processed, or distributed in commerce in violation of section 5 or 6 [15 U.S.C. $2604,2605]$, a rule or order under section 5 or 6 [15 U.S.C. 2604, 2605], or an order issued in action brought under section 5 or 7 [15 U.S.C. 2604, 2606];

(3) fail or refuse to (A) establish or maintain records, (B) submit reports, notices, or other information, or

(C) permit access to or copying of records, as required by this Act or a rule thereunder; or

(4) fail or refuse to permit entry or inspection as required by section 11 [15 U.S.C. 2610].

Penalties

[15 U.S.C. 2615]

Sec. 16. (a) Civil.-

(1) Any person who violates a provision of section 15 or 409 [15 U.S.C. 2614] shall be liable to the United States for a civil penalty in an amount not to exceed $\$ 25,000$ for each such violation. Each day such a violation continues shall, for purposes of this subsection, constitute a separate violation of section 15 or 409[15 U.S.C. 2614].

(2) (A) A civil penalty for a violation of section 15 or 409 [15 U.S.C. 2614] shall be assessed by the Administrator by an order made on the record after opportunity (provided in accordance with this subparagraph) for a hearing in accordance with section 554 of title 5, United States Code [5 U.S.C. 554]. Before issuing such an order, the Administrator shall give written notice to the person to be assessed a civil penalty under such order of the Administrator's proposal to issue such order and provide such person an opportunity to request, within 15 days of the date the notice is received by such person, such a hearing on the order.

(B) In determining the amount of a civil penalty, the Administrator shall take into account the nature, circumstances, extent, and gravity of the violation or violations and, with respect to the violator, ability to pay, effect on ability to continue to do business, any history of prior such violations, the degree of culpability, and such other matters as justice may require.

(C) The Administrator may compromise, modify, or remit, with or without conditions, any civil penalty which may be imposed under this subsection. The amount of such penalty, when finally determined, or the amount agreed upon in compromise, may be deducted from any sums owing by the United States to the person charged. 
(3) Any person who requested in accordance with paragraph (2)(A) a hearing respecting the assessment of a civil penalty and who is aggrieved by an order assessing a civil penalty may file a petition for judicial review of such order with the United States Court of Appeals for the District of Columbia Circuit or for any other circuit in which such person resides or transacts business. Such a petition may only be filed within the 30-day period beginning on the date the order making such assessment was issued.

(4) If any person fails to pay an assessment of a civil penalty-

(A) after the order making the assessment has become a final order and if such person does not file a petition for judicial review of the order in accordance with paragraph (3), or

(B) after a court in an action brought under paragraph (3) has entered a final judgment in favor of the Administrator, the Attorney General shall recover the amount assessed (plus interest at currently prevailing rates from the date of the expiration of the 30-day period referred to in paragraph (3) or the date of such final judgment, as the case may be) in an action brought in any appropriate district court of the United States. In such an action, the validity, amount, and appropriateness of such penalty shall not be subject to review.

(b) Criminal.-Any person who knowingly or willfully violates any provision of section 15 or 409 [15 U.S.C. 2614] shall, in addition to or in lieu of any civil penalty which may be imposed under subsection (a) of this section for such violation, be subject, upon conviction, to a fine of not more than $\$ 25,000$ for each day of violation, or to imprisonment for not more than one year, or both.

Specific Enforcement and Seizure

[15 U.S.C. 2616]

Sec. 17. (a) Specific enforcement.-

(1) The district courts of the United States shall have jurisdiction over civil actions to-

(A) restrain any violation of section 15 or 409 ,

(B) restrain any person from taking any action prohibited by section 5,6 , or title IV, or by a rule or order under section 5,6 , or title IV,

(C) compel the taking of any action required by or under this Act, or

(D) direct any manufacturer or processor of a chemical substance, mixture, or product subject to title IV manufactured or processed in violation of section 5,6 or title IV, or a rule or order under section 5,6 or title IV, and distributed in commerce, (i) to give notice of such fact to distributors in commerce of such substance, mixture, or product and, to the extent reasonably ascertainable, to other persons in possession of such substance, mixture or product or exposed to such substance or mixture, (ii) to give public notice of such risk of injury, and (iii) to either replace or repurchase such substance, mixture, or product, whichever the person to which the requirement is directed elects.

(2) A civil action described in paragraph (1) may be brought-

(A) in the case of a civil action described in subparagraph (A) of such paragraph, in the United States district court for the judicial district wherein any act, omission, or transaction constituting a violation of section 15 [15 U.S.C. 2614] occurred or wherein the defendant is found or transacts business, or

(B) in the case of any other civil action described in such paragraph, in the United States district court for the judicial district wherein the defendant is found or transacts business.

In any such civil action process may be served on a defendant in any judicial district in which a defendant resides or may be found. Subpoenas requiring attendance of witnesses in any such action may be served in any judicial district.

(b) Seizure,-Any chemical substance, mixture, or product subject to title IV, which was manufactured, processed, or distributed in commerce in violation of this Act or any rule promulgated or order issued under this Act or any article containing such a substance or mixture shall be liable to be proceeded against, by process of libel for the seizure and condemnation of such substance, mixture, product, or article, in any district court of the United States within the jurisdiction of which such substance, mixture, product, or article is found. Such proceedings shall conform as nearly as possible to proceedings in rem in admiralty.

Preemption

[15 U.S.C. 2617]

Sec. 18

(a) Effect on State law.- 
(1) Except as provided in paragraph (2), nothing in this Act shall affect the authority of any State or political subdivision of a State to establish or continue in effect regulation of any chemical substance, mixture, or article containing a chemical substance or mixture.

(2) Except as provided in subsection (b)-

(A) if the Administrator requires by a rule promulgated under section 4 [15 U.S.C. 2603] the testing of a chemical substance or mixture, no State or political subdivision may, after the effective date of such rule, establish or continue in effect a requirement for the testing of such substance or mixture for purposes similar to those for which testing is required under such rule; and

(B) if the Administrator prescribes a rule or order under section 5 or 6 [15 U.S.C. 2604, 2605](other than a rule imposing a requirement described in subsection (a)(6) of section 6 [15 U.S.C. 2605(a)(6)]) which is applicable to a chemical substance or mixture, and which is designed to protect against a risk of injury to health or the environment associated with such substance or mixture, no State or political subdivision of a State may, after the effective date of such requirement, establish or continue in effect, any requirement which is applicable to such substance or mixture, or an article containing such substance or mixture, and which is designed to protect against such risk unless such requirement (i) is identical to the requirement prescribed by the Administrator, (ii) is adopted under the authority of the Clean Air Act or any other Federal law, or (iii) prohibits the use of such substance or mixture in such State or political subdivision (other than its use in the manufacture or processing of other substances or mixtures).

(b) Exemption.-Upon application of a State or political subdivision of a State the Administrator may by rule exempt from subsection (a)(2), under such conditions as may be prescribed in such rule, a requirement of such State or political subdivision designed to protect against a risk of injury to health or the environment associated with a chemical substance, mixture, or article containing a chemical substance or mixture if-

(1) compliance with the requirement would not cause the manufacturing, processing, distribution in commerce, or use of the substance, mixture, or article to be in violation of the applicable requirement under this Act described in subsection (a)(2), and

(2) the State or political subdivision requirement (A) provides a significantly higher degree of protection from such risk than the requirement under this Act described in subsection (a)(2) and (B) does not, through difficulties in marketing, distribution, or other factors, unduly burden interstate commerce.

\section{Judicial Review}

[15 U.S.C. 2618]

Sec. 19. (a) In general.-

(1) (A) Not later than 60 days after the date of the promulgation of a rule under section 4(a), 5(a)(2), 5(b)(4), 6(a), 6(e), or 8 [15 U.S.C. 2603(a), 2604(a)(2), (b)(4), 2605(a), (e), 2607] or under title II or IV, any person may file a petition for judicial review of such rule with the United States Court of Appeals for the District of Columbia Circuit or for the circuit in which such person resides or in which such person's principal place of business is located. Courts of appeals of the United States shall have exclusive jurisdiction of any action to obtain judicial review (other than in an enforcement proceeding) of such a rule if any district court of the United States would have had jurisdiction of such action but for this subparagraph.

(B) Courts of appeals of the United States shall have exclusive jurisdiction of any action to obtain judicial review (other than in an enforcement proceeding) of an order issued under subparagraph (A) or (B) of section 6(b)(1) [15 U.S.C. 2605(b)(1)] if any district court of the United States would have had jurisdiction of such action but for this subparagraph.

(2) Copies of any petition filed under paragraph (1)(A) shall be transmitted forthwith to the Administrator and to the Attorney General by the clerk of the court with which such petition was filed. The provisions of section 2112 of title 28 , United States Code [28 U.S.C. 2112], shall apply to the filing of the rulemaking record of proceedings on which the Administrator based the rule being reviewed under this section and to the transfer of proceedings between United States courts of appeals.

(3) For purposes of this section, the term "rulemaking record" means-

(A) the rule being reviewed under this section;

(B) in the case of a rule under section 4(a) [15 U.S.C. 2603(a)], the finding required by such section, in the case of a rule under section 5(b)(4) [15 U.S.C. 2604(b)(4)], the finding required by such section, in the case of a rule under section 6(a) [15 U.S.C. 2605(a)] the finding required by section 5(f) $[15$ 
U.S.C. 2604(f)] or 6(a) [15 U.S.C. 2605(a)], as the case may be, in the case of a rule under section 6(a) [15 U.S.C. 2605(a)], the statement required by section 6(c)(1) [15 U.S.C. 2605(c)(1)], and in the case of a rule under section 6(e) [15 U.S.C. 2605(e)], the findings required by paragraph (2)(B) [15 U.S.C. $2605(\mathrm{e})(2)(B)]$ or (3)(B) [15 U.S.C. 2605(e)(3)(B)] of such section, as the case may be and in case of a rule under title IV, the finding required for the issuance of such a rule;

(C) any transcript required to be made of oral presentations made in proceedings for the promulgation of such rule;

(D) any written submission of interested parties respecting the promulgation of such rule; and

(E) any other information which the Administrator considers to be relevant to such rule and which the Administrator identified, on or before the date of the promulgation of such rule, in a notice published in the Federal Register.

(b) Additional submissions and presentations; modifications.-If in an action under this section to review a rule the petitioner or the Administrator applies to the court for leave to make additional oral submissions or written presentations respecting such rule and shows to the satisfaction of the court that such submissions and presentations would be material and that there were reasonable grounds for the submissions and failure to make such submissions and presentations in the proceeding before the Administrator, the court may order the Administrator to provide additional opportunity to make such submissions and presentations. The Administrator may modify or set aside the rule being reviewed or make a new rule by reason of the additional submissions and presentations and shall file such modified or new rule with the return of such submissions and presentations. The court shall thereafter review such new or modified rule.

(c) Standard of review.-

(1) (A) Upon the filing of a petition under subsection (a)(1) for judicial review of a rule, the court shall have jurisdiction (i) to grant appropriate relief, including interim relief, as provided in chapter 7 of title 5, United States Code [5 U.S.C. 701 et seq.], and (ii) except as otherwise provided in subparagraph (B), to review such rule in accordance with chapter 7 of title 5, United States Code [5 U.S.C. 701 et seq.].

(B) Section 706 of title 5, United States Code [5 U.S.C. 706], shall apply to review of a rule under this section, except that-

(i) in the case of review of a rule under section 4(a), 5(b)(4), 6(a), or 6(e) [15 U.S.C. 2603(a), 2604(b)(4), 2605(a), (e)], the standard for review prescribed by paragraph (2)(E) of such section 706 [5 U.S.C. 706(2)(E)] shall not apply and the court shall hold unlawful and set aside such rule if the court finds that the rule is not supported by substantial evidence in the rulemaking record (as defined in subsection (a)(3)) taken as a whole;

(ii) in the case of review of a rule under section 6(a) [15 U.S.C. 2605(a)], the court shall hold unlawful and set aside such rule if it finds that-

(I) a determination by the Administrator under section 6(c)(3) [15 U.S.C. 2605(c)(3)] that the petitioner seeking review of such rule is not entitled to conduct (or have conducted) cross-examination or to present rebuttal submissions, or

(II) a rule of, or ruling by, the Administrator under section 6(c)(3) [15 U.S.C. 2605(c)(3)] limiting such petitioner's cross-examination or oral presentations, has precluded disclosure of disputed material facts which was necessary to a fair determination by the Administrator of the rulemaking proceeding taken as a whole; and section 706(2)(D) [5 U.S.C. 706(2)(D)] shall not apply with respect to a determination, rule, or ruling referred to in subclause (I) or (II); and

(iii) the court may not review the contents and adequacy of -

(I) any statement required to be made pursuant to section 6(c)(1) [15 U.S.C. 2605(c)(1)], or

(II) any statement of basis and purpose required by section 553(c) of title 5, United States Code [5 U.S.C. 553(c)], to be incorporated in the rule except as part of a review of the rulemaking record taken as a whole.

The term "evidence" as used in clause (i) means any matter in the rulemaking record.

(C) A determination, rule, or ruling of the Administrator described in subparagraph (B)(ii) may be reviewed only in an action under this section and only in accordance with such subparagraph.

(2) The judgment of the court affirming or setting aside, in whole or in part, any rule reviewed in accordance with this section shall be final, subject to review by the Supreme Court of the United States upon certiorari or certification, as provided in section 1254 of title 28, United States Code [28 U.S.C. 1254]. 
(d) Fees and costs.-The decision of the court in an action commenced under subsection (a), or of the Supreme Court of the United States on review of such a decision, may include an award of costs of suit and reasonable fees for attorneys and expert witnesses if the court determines that such an award is appropriate.

(e) Other remedies. - The remedies as provided in this section shall be in addition to and not in lieu of any other remedies provided by law.

\section{Citizens' Civil Actions}

[15 U.S.C. 2619]

Sec. 20. (a) In general.-Except as provided in subsection (b), any person may commence a civil action(1) against any person (including (A) the United States, and (B) any other governmental instrumentality or agency to the extent permitted by the eleventh amendment to the Constitution) who is alleged to be in violation of this Act or any rule promulgated under section 4, 5, or 6 [15 U.S.C. 2603-2605], or title II or IV, or order issued under section 5 [15 U.S.C. 2604] or title II or IV to restrain such violation, or

(2) against the Administrator to compel the Administrator to perform any act or duty under this Act which is not discretionary.

Any civil action under paragraph (1) shall be brought in the United States district court for the district in which the alleged violation occurred or in which the defendant resides or in which the defendant's principal place of business is located. Any action brought under paragraph (2) shall be brought in the United States District Court for the District of Columbia, or the United States district court for the judicial district in which the plaintiff is domiciled. The district courts of the United States shall have jurisdiction over suits brought under this section, without regard to the amount in controversy or the citizenship of the parties. In any civil action under this subsection process may be served on a defendant in any judicial district in which the defendant resides or may be found and subpoenas for witnesses may be served in any judicial district.

(b) Limitation.-No civil action may be commenced-

(1) under subsection (a)(1) to restrain a violation of this Act or rule or order under this Act-

(A) before the expiration of 60 days after the plaintiff has given notice of such violation (i) to the Administrator, and (ii) to the person who is alleged to have committed such violation, or

(B) if the Administrator has commenced and is diligently prosecuting a proceeding for the issuance of an order under section 16(a)(2) [15 U.S.C. 2615(a)(2)] to require compliance with this Act or with such rule or order or if the Attorney General has commenced and is diligently prosecuting a civil action in a court of the United States to require compliance with this Act or with such rule or order, but if such proceeding or civil action is commenced after the giving of notice, any person giving such notice may intervene as a matter of right in such proceeding or action; or

(2) under subsection (a)(2) before the expiration of 60 days after the plaintiff has given notice to the Administrator of the alleged failure of the administrator to perform an act or duty which is the basis for such action or, in the case of an action under such subsection for the failure of the Administrator to file an action under section 7 [15 U.S.C. 2606], before the expiration of ten days after such notification.

Notice under this subsection shall be given in such manner as the Administrator shall prescribe by rule.

(c) General.-

(1) In any action under this section, the Administrator, if not a party, may intervene as a matter of right.

(2) The court, in issuing any final order in any action brought pursuant to subsection (a), may award costs of suit and reasonable fees for attorneys and expert witnesses if the court determines that such an award is appropriate. Any court, in issuing its decision in an action brought to review such an order, may award costs of suit and reasonable fees for attorneys if the court determines that such an award is appropriate.

(3) Nothing in this section shall restrict any right which any person (or class of persons) may have under any statute or common law to seek enforcement of this Act or any rule or order under this Act or to seek any other relief.

(d) Consolidation.-When two or more civil actions brought under subsection (a) involving the same defendant and the same issues or violations are pending in two or more judicial districts, such pending actions, upon application of such defendants to such actions which is made to a court in which any such action is brought, may, if such court in its discretion so decides, be consolidated for trial by order (issued after giving all parties reasonable notice and opportunity to be heard) of such court and tried in-

(1) any district which is selected by such defendant and in which one of such actions is pending,

(2) a district which is agreed upon by stipulation between all the parties to such actions and in which one of such actions is pending, or 
(3) a district which is selected by the court and in which one of such actions is pending. The court issuing such an order shall give prompt notification of the order to the other courts in which the civil actions consolidated under the order are pending.

\section{Citizens' Petitions}

[15 U.S.C. 2620]

Sec. 21 .

(a) In general.-Any person may petition the Administrator to initiate a proceeding for the issuance, amendment, or repeal of a rule under section 4, 6, or 8 [15 U.S.C. 2603, 2605, 2607] or an order under section 5(e) or (6)(b)(2) [15 U.S.C. 2604(e), 2605(b)(2)].

(b) Procedures.-

(1) Such petition shall be filed in the principal office of the Administrator and shall set forth the facts which it is claimed establish that it is necessary to issue, amend, or repeal a rule under section 4,6 , or 8 [15 U.S.C. $2603,2605,2607]$ or an order under section $5(\mathrm{e}), 6(\mathrm{~b})(1)(\mathrm{A})$, or $6(\mathrm{~b})(1)(\mathrm{B})$ [15 U.S.C. 2604(e), 2605(b)(1)(A), (B)].

(2) The Administrator may hold a public hearing or may conduct such investigation or proceeding as the Administrator deems appropriate in order to determine whether or not such petition should be granted.

(3) Within 90 days after filing of a petition described in paragraph (1), the Administrator shall either grant or deny the petition. If the Administrator grants such petition, the Administrator shall promptly commence an appropriate proceeding in accordance with section $4,5,6$, or 8 [15 U.S.C. 2603-2605, 2607]. If the Administrator denies such petition, the Administrator shall publish in the Federal Register the Administrator's reasons for such denial.

(4) (A) If the Administrator denies a petition filed under this section (or if the Administrator fails to grant or deny such petition within the 90-day period) the petitioner may commence a civil action in a district court of the United States to compel the Administrator to initiate a rulemaking proceeding as requested in the petition. Any such action shall be filed within 60 days after the Administrator's denial of the petition or, if the Administrator fails to grant or deny the petition within 90 days after filing the petition, within 60 days after the expiration of the 90-day period.

(B) In an action under subparagraph (A) respecting a petition to initiate a proceeding to issue a rule under section 4,6 , or 8 [15 U.S.C. 2603, 2605, 2607] or an order under section 5(e) or 6(b)(2) [15 U.S.C. 2604(e), 2605(b)(2)], the petitioner shall be provided an opportunity to have such petition considered by the court in a de novo proceeding. If the petitioner demonstrates to the satisfaction of the court by a preponderance of the evidence that-

(i) in the case of a petition to initiate a proceeding for the issuance of a rule under section 4 [15

U.S.C. 2603] or an order under section 5(e) [15 U.S.C. 2.604(e)]-

(I) information available to the Administrator is insufficient to permit a reasoned evaluation of the health and environmental effects of the chemical substance to be subject to such rule or order; and

(II) in the absence of such information, the substance may present an unreasonable risk to health or the environment, or the substance is or will be produced in substantial quantities and it enters or may reasonably be anticipated to enter the environment in substantial quantities or there is or may be significant or substantial human exposure to it; or

(ii) in the case of a petition to initiate a proceeding for the issuance of a rule under section 6 or 8 [15 U.S.C. 2605, 2607] or an order under section 6(b)(2) [15 U.S.C. 2605(b)(2)], there is a reasonable basis to conclude that the issuance of such a rule or order is necessary to protect health or the environment against an unreasonable risk of injury to health or the environment the court shall order the Administrator to initiate the action requested by the petitioner. If the court finds that the extent of the risk to health or the environment alleged by the petitioner is less than the extent of risks to health or the environment with respect to which the Administrator is taking action under this Act [15 U.S.C. 2601 et seq.] and there are insufficient resources available to the Administrator to take the action requested by the petitioner, the court may permit the Administrator to defer initiating the action requested by the petitioner until such time as the court prescribes.

(C) The court in issuing any final order in any action brought pursuant to subparagraph (A) may award costs of suit and reasonable fees for attorneys and expert witnesses if the court determines that such an award is appropriate. Any court, in issuing its decision in an action brought to review such an order, 
may award costs of suit and reasonable fees for attorneys if the court determines that such an award is appropriate.

(5) The remedies under this section shall be in addition to, and not in lieu of, other remedies provided by law.

\section{National Defense Waiver}

[15 U.S.C. 2621]

Sec. 22. The Administrator shall waive compliance with any provision of this Act upon a request and determination by the President that the requested waiver is necessary in the interest of national defense. The Administrator shall maintain a written record of the basis upon which such waiver was granted and make such record available for in camera examination when relevant in a judicial proceeding under this Act. Upon the issuance of such a waiver, the Administrator shall publish in the Federal Register a notice that the waiver was granted for national defense purposes, unless, upon the request of the President, the Administrator determines to omit such publication because the publication itself would be contrary to the interests of national defense, in which event the Administrator shall submit notice thereof to the Armed Services Committees of the Senate and the House of Representatives.

\section{Employee Protection}

[15 U.S.C. 2622]

Sec. 23. (a) In general.-No employer may discharge any employee or otherwise discriminate against any employee with respect to the employee's compensation, terms, conditions, or privileges of employment because the employee (or any person acting pursuant to a request of the employee) has-

(1) commenced, caused to be commenced, or is about to commence or cause to be commenced a proceeding under this Act;

(2) testified or is about to testify in any such proceeding; or

(3) assisted or participated or is about to assist or participate in any manner in such a proceeding or in any other action to carry out the purposes of this Act.

(b) Remedy.-

(1) Any employee who believes that the employee has been discharged or otherwise discriminated against by any person in violation of subsection (a) of this section may, within 30 days after such alleged violation occurs, file (or have any person file on the employee's behalf) a complaint with the Secretary of Labor (hereinafter in this section referred to as the "Secretary") alleging such discharge or discrimination. Upon receipt of such a complaint, the Secretary shall notify the person named in the complaint of the filing of the complaint.

(2) (A) Upon receipt of a complaint filed under paragraph (1), the Secretary shall conduct an investigation of the violation alleged in the complaint. Within 30 days of the receipt of such complaint, the Secretary shall complete such investigation and shall notify in writing the complainant (and any person acting on behalf of the complainant) and the person alleged to have committed such violation of the results of the investigation conducted pursuant to this paragraph. Within ninety days of the receipt of such complaint the Secretary shall, unless the proceeding on the complaint is terminated by the Secretary on the basis of a settlement entered into by the Secretary and the person alleged to have committed such violation, issue an order either providing the relief prescribed by subparagraph (B) or denying the complaint. An order of the Secretary shall be made on the record after notice and opportunity for agency hearing. The Secretary may not enter into a settlement terminating a proceeding on a complaint without the participation and consent of the complainant.

(B) If in response to a complaint filed under paragraph (1) the Secretary determines that a violation of subsection (a) of this section has occurred, the Secretary shall order (i) the person who committed such violation to take affirmative action to abate the violation, (ii) such person to reinstate the complainant to the complainant's former position together with the compensation (including back pay), terms, conditions, and privileges of the complainant's employment, (iii) compensatory damages, and (iv) where appropriate, exemplary damages. If such an order issued, the Secretary, at the request of the complainant, shall assess against the person against whom the order is issued a sum equal to the aggregate amount of all costs and expenses (including attorney's fees) reasonably incurred, as 
determined by the Secretary, by the complainant for, or in connection with, the bringing of the complaint upon which the order was issued.

(c) Review.-

(1) Any employee or employer adversely affected or aggrieved by an order issued under subsection (b) may obtain review of the order in the United States Court of Appeals for the circuit in which the violation, with respect to which the order was issued, allegedly occurred. The petition for review must be filed within sixty days from the issuance of the Secretary's order. Review shall conform to chapter 7 of title 5 of the United States Code [5 U.S.C. 701 et seq.].

(2) An order of the Secretary, with respect to which review could have been obtained under paragraph (1), shall not be subject to judicial review in any criminal or other civil proceeding.

(d) Enforcement.-Whenever a person has failed to comply with an order issued under subsection (b)(2), the Secretary shall file a civil action in the United States district court for the district in which the violation was found to occur to enforce such order. In actions brought under this subsection, the district courts shall have jurisdiction to grant all appropriate relief, including injunctive relief and compensatory and exemplary damages.

(e) Exclusion.-Subsection (a) of this section shall not apply with respect to any employee who, acting without direction from the employee's employer (or any agent of the employer), deliberately causes a violation of any requirement of this Act.

\section{Employment Effects}

[15 U.S.C. 2623]

Sec. 24. (a) In general.-The Administrator shall evaluate on a continuing basis the potential effects on employment (including reductions in employment or loss of employment from threatened plant closures) of-

(1) the issuance of a rule or order under section 4, 5, or 6 [15 U.S.C. 2603-2605], or (2) a requirement of section 5 or 6 [15 U.S.C. 2604, 2605].

(b) Investigations.--

(1) Any employee (or any representative of an employee) may request the Administrator to make an investigation of-

(A) a discharge or layoff or threatened discharge or layoff of the employee, or

(B) adverse or threatened adverse effects on the employee's employment, allegedly resulting from a rule or order under section 4, 5, or 6 [15 U.S.C. 2603-2605] or a requirement of section 5 or 6 [15 U.S.C. 2604, 2605]. Any such request shall be made in writing, shall set forth with reasonable particularity the grounds for the request, and shall be signed by the employee, or representative of such employee, making the request.

(2) (A) Upon receipt of a request made in accordance with paragraph (1) the Administrator shall (i) conduct the investigation requested, and (ii) if requested by any interested person, hold public hearings on any matter involved in the investigation unless the Administrator, by order issued within 45 days of the date such hearings are requested, denies the request for the hearings because the Administrator determines there are no reasonable grounds for holding such hearings. If the Administrator makes such a determination, the Administrator shall notify in writing the person requesting the hearing of the determination and the reasons therefor and shall publish the determination and the reasons therefor in the Federal Register.

(B) If public hearings are to be held on any matter involved in an investigation conducted under this subsection-

(i) at least five days' notice shall be provided the person making the request for the investigation and any person identified in such request,

(ii) such hearings shall be held in accordance with section 6(c)(3) [15 U.S.C. 2605(c)(3)], and

(iii) each employee who made or for whom was made a request for such hearings and the employer of such employee shall be required to present information respecting the applicable matter referred to in paragraph (1)(A) or (1)(B) together with the basis for such information.

(3) Upon completion of an investigation under paragraph (2), the Administrator shall make findings of fact, shall make such recommendations as the Administrator deems appropriate, and shall make available to the public such findings and recommendations.

(4) This section shall not be construed to require the Administrator to amend or repeal any rule or order in effect under this Act [15 U.S.C. 2601 et seq.]. 
Studies

[15 U.S.C. 2624]

Sec. 25. (a) Indemnification study.-The Administrator shall conduct a study of all Federal laws administered by the Administrator for the purpose of determining whether and under what conditions, if any, indemnification should be accorded any person as a result of any action taken by the Administrator under any such law. The study shall-

(1) include an estimate of the probable cost of any indemnification programs which may be recommended;

(2) include an examination of all viable means of financing the cost of any recommended indemnification; and

(3) be completed and submitted to Congress within two years from the effective date of enactment of this

Act [see effective date note to 15 U.S.C. 2601].

The General Accounting Office shall review the adequacy of the study submitted to Congress pursuant to paragraph (3) and shall report the results of its review to the Congress within six months of the date such study is submitted to Congress.

(b) Classification, storage, and retrieval study.-The Council on Environmental Quality, in consultation with the Administrator, the Secretary of Health, Education, and Welfare, the Secretary of Commerce, and the heads of other appropriate Federal departments or agencies, shall coordinate a study of the feasibility of establishing (1) a standard classification system for chemical substances and related substances, and (2) a standard means for storing and for obtaining rapid access to information respecting such substances. A report on such study shall be completed and submitted to Congress not later than 18 months after the effective date of enactment of this Act [see effective date note to 15 U.S.C. 2601].

\section{Administration}

[15 U.S.C. 2625]

Sec. 26. (a) Cooperation of Federal agencies.-Upon request by the Administrator, each Federal department and agency is authorized-

(1) to make its services, personnel, and facilities available (with or without reimbursement) to the Administrator to assist the Administrator in the administration of this Act; and

(2) to furnish to the Administrator such information, data, estimates, and statistics, and to allow the Administrator access to all information in its possession as the Administrator may reasonably determine to be necessary for the administration of this Act.

(b) Fees.-

(1) The Administrator may, by rule, require the payment of a reasonable fee from any person required to submit data under section 4 or 5 [15 U.S.C. 2603, 2604] to defray the cost of administering this Act. Such rules shall not provide for any fee in excess of $\$ 2,500$ or, in the case of a small business concern, any fee in excess of $\$ 100$. In setting a fee under this paragraph, the Administrator shall take into account the ability to pay of the person required to submit the data and the cost to the Administrator of reviewing such data. Such rules may provide for sharing such a fee in any case in which the expenses of testing are shared under section 4 or 5 [15 U.S.C. 2603, 2604].

(2) The Administrator, after consultation with the Administrator of the Small Business Administration, shall by rule prescribe standards for determining the persons which qualify as small business concerns for purposes of paragraph (1).

(c) Action with respect to categories.-

(1) Any action authorized or required to be taken by the Administrator under any provision of this Act with respect to a chemical substance or mixture may be taken by the Administrator in accordance with that provision with respect to a category of chemical substances or mixtures. Whenever the Administrator takes action under a provision of this Act with respect to a category of chemical substances or mixtures, any reference in this Act to a chemical substance or mixture (insofar as it relates to such action) shall be deemed to be a reference to each chemical substance or mixture in such category.

(2) For purposes of paragraph (1):

(A) The term "category of chemical substances" means a group of chemical substances the members of which are similar in molecular structure, in physical, chemical, or biological properties, in use, or in mode of entrance into the human body or into the environment, or the members of which are in some other way suitable for classification as such for purposes of this Act, except that such term does not 
mean a group of chemical substances which are grouped together solely on the basis of their being new chemical substances.

(B) The term "category of mixtures" means a group of mixtures the members of which are similar in molecular structure, in physical, chemical, or biological properties, in use, or in the mode of entrance into the human body or into the environment, or the members of which are in some other way suitable for classification as such for purposes of this Act.

(d) Assistance office.-The Administrator shall establish in the Environmental Protection Agency an identifiable office to provide technical and other nonfinancial assistance to manufacturers and processors of chemical substances and mixtures respecting the requirements of this Act applicable to such manufacturers and processors, the policy of the Agency respecting the application of such requirements to such manufacturers and processors, and the means and methods by which such manufacturers and processors may comply with such requirements.

(e) Financial disclosures.-

(1) Except as provided under paragraph (3), each officer or employee of the Environmental Protection Agency and the Department of Health, Education, and Welfare who-

(A) performs any function or duty under this Act, and

(B) has any known financial interest (i) in any person subject to this Act or any rule or order in effect under this Act, or (ii) in any person who applies for or receives any grant or contract under this Act, shall, on February 1, 1978, and on February 1 of each year thereafter, file with the Administrator or the Secretary of Health, Education, and Welfare (hereinafter in this subsection referred to as the "Secretary"), as appropriate, a written statement concerning all such interests held by such officer or employee during the preceding calendar year. Such statement shall be made available to the public.

(2) The Administrator and the Secretary shall-

(A) act within 90 days of the effective date of this Act [see effective date note to 15 U.S.C. 2601]-

(i) to define the term "known financial interests" for purposes of paragraph (1), and

(ii) to establish the methods by which the requirement to file written statements specified in paragraph (1) will be monitored and enforced, including appropriate provisions for review by the Administrator and the Secretary of such statements; and

(B) report to the Congress on June 1, 1978, and on June 1 of each year thereafter with respect to such statements and the actions taken in regard thereto during the preceding calendar year.

(3) The Administrator may by rule identify specific positions with the Environmental Protection Agency, and the Secretary may by rule identify specific positions with the Department of Health, Education, and Welfare, which are of a nonregulatory or nonpolicymaking nature, and the Administrator and the Secretary may by rule provide that officers or employees occupying such positions shall be exempt from the requirements of paragraph (1).

(4) This subsection does not supersede any requirement of chapter 11 of title 18, United States Code [18 U.S.C. 201 et seq.].

(5) Any officer or employee who is subject to, and knowingly violates, this subsection or any rule issued thereunder, shall be fined not more than $\$ 2,500$ or imprisoned not more than one year, or both.

(f) Statement of basis and purpose.-Any final order issued under this Act shall be accompanied by a statement of its basis and purpose. The contents and adequacy of any such statement shall not be subject to judicial review in any respect.

(g) Assistant Administrator.-

(1) The President, by and with the advice and consent of the Senate, shall appoint an Assistant Administrator for Toxic Substances of the Environmental Protection Agency. Such Assistant Administrator shall be a qualified individual who is, by reason of background and experience, especially qualified to direct a program concerning the effects of chemicals on human health and the environment. Such Assistant Administrator shall be responsible for (A) the collection of data, (B) the preparation of studies, (C) the making of recommendations to the Administrator for regulatory and other actions to carry out the purposes and to facilitate the administration of this Act, and (D) such other functions as the Administrator may assign or delegate.

(2) The Assistant Administrator to be appointed under paragraph (1) shall be in addition to the Assistant Administrators of the Environmental Protection Agency authorized by section 1(d) of Reorganization Plan No. 3 of 1970 [5 U.S.C. 903 note]. 
Sec. 27. (a) In general.-The Secretary of Health, Education, and Welfare, in consultation with the Administrator and acting through the Assistant Secretary for Health, may conduct, and make grants to public and nonprofit private entities and enter into contracts with public and private entities for, projects for the development and evaluation of inexpensive and efficient methods (1) for determining and evaluating the health and environmental effects of chemical substances and mixtures, and their toxicity, persistence, and other characteristics which affect health and the environment, and (2) which may be used for the development of test data to meet the requirements of rules promulgated under section 4 [15 U.S.C. 2603]. The Administrator shall consider such methods in prescribing under section 4 [15 U.S.C. 2603] standards for the development of test data.

(b) Approval by Secretary.-No grant may be made or contract entered into under subsection (a) unless an application therefor has been submitted to and approved by the Secretary. Such an application shall be submitted in such form and manner and contain such information as the Secretary may require. The Secretary may apply such conditions to grants and contracts under subsection (a) as the Secretary determines are necessary to carry out the purposes of such subsection. Contracts may be entered into under such subsection without regard to sections 3648 and 3709 of the Revised Statutes (31 U.S.C. 529; 41 U.S.C. 5) [31 U.S.C. 529; 41 U.S.C. 5].

(c) Annual reports.-

(1) The Secretary shall prepare and submit to the President and the Congress on or before January 1 of each year a report of the number of grants made and contracts entered into under this section and the results of such grants and contracts.

(2) The Secretary shall periodically publish in the Federal Register reports describing the progress and results of any contract entered into or grant made under this section.

State Programs

[15 U.S.C. 2627]

Sec. 28. (a) In general.-For the purpose of complementing (but not reducing) the authority of, or actions taken by, the Administrator under this Act, the Administrator may make grants to States for the establishment and operation of programs to prevent or eliminate unreasonable risks within the States to health or the environment which are associated with a chemical substance or mixture and with respect to which the Administrator is unable or is not likely to take action under this Act for their prevention or elimination. The amount of a grant under this subsection shall be determined by the Administrator, except that no grant for any State program may exceed 75 per centum of the establishment and operation costs (as determined by the Administrator) of such program during the period for which the grant is made.

(b) Approval by Administrator.-

(1) No grant may be made under subsection (a) unless an application therefor is submitted to and approved by the Administrator. Such an application shall be submitted in such form and manner as the Administrator may require and shall-

(A) set forth the need of the applicant for a grant under subsection (a),

(B) identify the agency or agencies of the State which shall establish or operate, or both, the program for which the application is submitted,

(C) describe the actions proposed to be taken under such program,

(D) contain or be supported by assurances satisfactory to the Administrator that such program shall, to the extent feasible, be integrated with other programs of the applicant for environmental and public health protection,

(E) provide for the making of such reports and evaluations as the Administrator may require, and

(F) contain such other information as the Administrator may prescribe.

(2) The Administrator may approve an application submitted in accordance with paragraph (1) only if the applicant has established to the satisfaction of the Administrator a priority need, as determined under rules of the Administrator, for the grant for which the application has been submitted. Such rules shall take into consideration the seriousness of the health effects in a State which are associated with chemical substances or mixtures, including cancer, birth defects, and gene mutations, the extent of the exposure in a State of human beings and the environment to chemical substances and mixtures, and the extent to which chemical substances and mixtures are manufactured, processed, used, and disposed of in a State. 
(c) Annual reports.-Not later than six months after the end of each of the fiscal years 1979, 1980, and 1981, the Administrator shall submit to the Congress a report respecting the programs assisted by grants under subsection (a) in the preceding fiscal year and the extent to which the Administrator has disseminated information respecting such programs.

(d) Authorization.-For the purpose of making grants under subsection (a), there are authorized to be appropriated $\$ 1,500,000$ for each of the fiscal years 1982 and 1983. Sums appropriated under this subsection shall remain available until expended.

\title{
Authorization of Appropriations
}

[15 U.S.C. 2628]

Sec. 29. There are authorized to be appropriated to the Administrator for purposes of carrying out this Act [15 U.S.C. 2601 et seq.] (other than sections 27 and 28 and subsections (a) and (c) through (g) of section 10 thereof [15 U.S.C. 2609 (a), (c)-(g), 2626, 2627]) $\$ 58,646,000$ for the fiscal year 1982 and $\$ 62,000,000$ for the fiscal year 1983. No part of the funds appropriated under this section may be used to construct any research laboratories.

\section{Annual Report}

[15 U.S.C. 2629]

Sec. 30. The Administrator shall prepare and submit to the President and the Congress on or before January 1,1978 , and on or before January 1 of each succeeding year a comprehensive report on the administration of this Act during the preceding fiscal year. Such report shall include-

(1) a list of the testing required under section 4 [15 U.S.C. 2603] during the year for which the report is made and an estimate of the costs incurred during such year by the persons required to perform such tests; (2) the number of notices received during such year under section 5 [15 U.S.C. 2604], the number of such notices received during such year under such section for chemical substances subject to a section 4 [15 U.S.C. 2603] rule, and a summary of any action taken during such year under section $5(\mathrm{~g})$ [15 U.S.C. 2604(g)];

(3) a list of rules issued during such year under section 6 [15 U.S.C. 2605];

(4) a list, with a brief statement of the issues, of completed or pending judicial actions under this Act and administrative actions under section 16 [15 U.S.C. 2615] during such year;

(5) a summary of major problems encountered in the administration of this Act; and

(6) such recommendations for additional legislation as the Administrator deems necessary to carry out the purposes of this Act.

\section{TITLE II-ASBESTOS HAZARDOUS EMERGENCY RESPONSE}

\author{
Congressional Findings and Purpose
}

[15 U.S.C. 2641]

Sec. 201. (a) Findings.-The Congress finds the following:

(1) The Environmental Protection Agency's rule on local educational agency inspection for, and notification of, the presence of friable asbestos-containing material in school buildings includes neither standards for the proper identification of asbestos-containing material and appropriate response actions with respect to friable asbestos-containing material, nor a requirement that response actions with respect to friable asbestos-containing material be carried out in a safe and complete manner once actions are found to be necessary. As a result of the lack of regulatory guidance from the Environmental Protection Agency, some schools have not undertaken response action while many others have undertaken expensive projects without knowing if their action is necessary, adequate, or safe. Thus, the danger of exposure to asbestos continues to exist in schools, and some exposure actually may have increased due to the lack of Federal standards and improper response action.

(2) There is no uniform program for accrediting persons involved in asbestos identification and abatement, nor are local educational agencies required to use accredited contractors for asbestos work.

(3) The guidance provided by the Environmental Protection Agency in its "Guidance for Controlling Asbestos-Containing Material in Buildings" is insufficient in detail to ensure adequate responses. Such guidance is intended to be used only until the regulations required by this title become effective. 
(4) Because there are no Federal standards whatsoever regulating daily exposure to asbestos in other public and commercial buildings, persons in addition to those comprising the Nation's school population may be exposed daily to asbestos.

(b) Purpose.-The purpose of this title is-

(1) to provide for the establishment of Federal regulations which require inspection for asbestos-containing material and implementation of appropriate response actions with respect to asbestos-containing material in the Nation's schools in a safe and complete manner;

(2) to mandate safe and complete periodic reinspection of school buildings following response actions, where appropriate; and

(3) to require the Administrator to conduct a study to find out the extent of the danger to human health posed by asbestos in public and commercial buildings and the means to respond to any such danger.

\section{Definitions}

[15 U.S.C. 2642]

Sec. 202. For purposes of this title-

(1) Accredited asbestos contractor.-The term "accredited asbestos contractor" means a person accredited pursuant to the provisions of section 206 [15 U.S.C. 2646].

(2) Administrator.-The term "Administrator" means the Administrator of the Environmental Protection Agency.

(3) Asbestos.-The term "asbestos" means asbestiform varieties of-

(A) chrysotile (serpentine),

(B) crocidolite (riebeckite),

(C) amosite (cummingtonite-grunerite),

(D) anthophyllite,

(E) tremolite, or

(F) actinolite.

(4) Asbestos-containing material.-The term "asbestos-containing material" means any material which contains more than 1 percent asbestos by weight.

(5) EPA guidance document.-The term "Guidance for Controlling Asbestos-Containing Material in Buildings", means the Environmental Protection Agency document with such title as in effect on March $31,1986$.

(6) Friable asbestos-containing material.-The term "friable asbestos-containing material" means any asbestos-containing material applied on ceilings, walls, structural members, piping, duct work, or any other part of a building which when dry may be crumbled, pulverized, or reduced to powder by hand pressure. The term includes non-friable asbestos-containing material after such previously non-friable material becomes damaged to the extent that when dry it may be crumbled, pulverized, or reduced to powder by hand pressure.

(7) Local educational agency.-The term "local educational agency" means-

(A) any local educational agency as defined in section 198 of the Elementary and Secondary Education Act of 1965 (20 U.S.C. 3381),

(B) the owner of any private, nonprofit elementary or secondary school building, and

(C) the governing authority of any school operated under the defense dependents' education system provided for under the Defense Dependents' Education Act of 1978 (20 U.S.C. 921 et seq.).

(8) Most current guidance document.-The term "most current guidance document" means the Environmental Protection Agency's "Guidance for Controlling Asbestos-Containing Material in Buildings" as modified by the Environmental Protection Agency after March 31, 1986.

(9) Non-profit elementary or secondary school.-The term "non-profit elementary or secondary school" means any elementary or secondary school (as defined in section 198 of the Elementary and Secondary Education Act of 1965 (20 U.S.C. 2854)) owned and operated by one or more nonprofit corporations or associations no part of the net earnings of which inures, or may lawfully inure, to the benefit of any private shareholder or individual.

(10) Public and commercial building.-The term "public and commercial building" means any building which is not a school building, except that the term does not include any residential apartment building of fewer than 10 units. 
(11) Response action.-The term "response action" means methods that protect human health and the environment from asbestos-containing material. Such methods include methods described in chapters 3 and 5 of the Environmental Protection Agency's "Guidance for Controlling Asbestos-Containing Materials in Buildings".

(12) School.- The term "school" means any elementary or secondary school as defined in section 198 of the Elementary and Secondary Education Act of 1965 (20 U.S.C. 2854).

(13) School building.-The term "school building" means-

(A) any structure suitable for use as a classroom, including a school facility such as a laboratory, library, school eating facility, or facility used for the preparation of food,

(B) any gymnasium or other facility which is specially designed for athletic or recreational activities for an academic course in physical education,

(C) any other facility used for the instruction of students or for the administration of educational or research programs, and

(D) any maintenance, storage, or utility facility, including any hallway, essential to the operation of any facility described in subparagraphs (A), (B), or (C).

(14) State.-The term "State" means a State, the District of Columbia, the Commonwealth of Puerto Rico, Guam, American Samoa, the Northern Marianas, the Trust Territory of the Pacific Islands, and the Virgin Islands.

\section{EPA Regulations}

[15 U.S.C. 2643]

Sec. 203 1986], the Administrator shall promulgate regulations as described in subsections (b) through (i). With respect to regulations described in subsections (b), (c), (d), (e), (f), (g), and (i), the Administrator shall issue an advanced notice of proposed rulemaking within 60 days after the date of the enactment of this title [enacted Oct. 22 , 1986], and shall propose regulations within 180 days after such date. Any regulation promulgated under this section must protect human health and the environment.

(b) Inspection.-The Administrator shall promulgate regulations which prescribe procedures, including the use of personnel accredited under section 206(b) [15 U.S.C. 2646(b)] or 206(c) [15 U.S.C. 2646(c)] and laboratories accredited under section 206(d) [15 U.S.C. 2646(d)], for determining whether asbestos-containing material is present in a school building under the authority of a local educational agency. The regulations shall provide for the exclusion of any school building, or portion of a school building, if (1) an inspection of such school building (or portion) was completed before the effective date of the regulations, and (2) the inspection meets the procedures and other requirements of the regulations under this title or of the "Guidance for Controlling Asbestos-Containing Materials in Buildings" (unless the Administrator determines that an inspection in accordance with the guidance document is inadequate). The regulations shall require inspection of any school building (or portion of a school building) that is not excluded by the preceding sentence.

(c) Circumstances requiring response actions.-

(1) The Administrator shall promulgate regulations which define the appropriate response action in a school building under the authority of a local educational agency in at least the following circumstances:

(A) Damage.-Circumstances in which friable asbestos-containing material or its covering is damaged, deteriorated, or delaminated.

(B) Significant damage.-Circumstances in which friable asbestos-containing material or its covering is significantly damaged, deteriorated, or delaminated.

(C) Potential damage. Circumstances in which-

(i) friable asbestos-containing material is in an area regularly used by building occupants, including maintenance personnel, in the course of their normal activities, and

(ii) there is a reasonable likelihood that the material or its covering will become damaged, deteriorated, or delaminated.

(D) Potential significant damage. Circumstances in which-

(i) friable asbestos-containing material is in an area regularly used by building occupants, including maintenance personnel, in the course of their normal activities, and

(ii) there is a reasonable likelihood that the material or its covering will become significantly damaged, deteriorated, or delaminated. 
(2) In promulgating such regulations, the Administrator shall consider and assess the value of various technologies intended to improve the decisionmaking process regarding response actions and the quality of any work that is deemed necessary, including air monitoring and chemical encapsulants.

(d) Response actions.-

(1) In general.-The Administrator shall promulgate regulations describing a response action in a school building under the authority of a local educational agency, using the least burdensome methods which protect human health and the environment. In determining the least burdensome methods, the Administrator shall take into account local circumstances, including occupancy and use patterns within the school building and short-and long-term costs.

(2) Response action for damaged asbestos.-In the case of a response action for the circumstances described in subsection (c)(1)(A), methods for responding shall include methods identified in chapters 3 and 5 of the "Guidance for Controlling Asbestos-Containing Material in Buildings".

(3) Response action for significantly damaged asbestos.-In the case of a response action for the circumstances described in subsection (c)(1)(B), methods for responding shall include methods identified in chapter 5 of the "Guidance for Controlling Asbestos-Containing Material in Buildings".

(4) Response action for potentially damaged asbestos.-In the case of a response action for the circumstances described in subsection (c)(1)(C), methods for responding shall include methods identified in chapters 3 and 5 of the "Guidance for Controlling Asbestos-Containing Material in Buildings", unless preventive measures will eliminate the reasonable likelihood that the asbestos-containing material will become damaged, deteriorated, or delaminated.

(5) Response action for potentially significantly damaged asbestos.--In the case of a response action for the circumstances described in subsection (c)(1)(D), methods for responding shall include methods identified in chapter 5 of the "Guidance for Controlling Asbestos-Containing Material in Buildings", unless preventive measures will eliminate the reasonable likelihood that the asbestos-containing material will become significantly damaged, deteriorated, or delaminated.

(6) Preventive measures defined.0-For purposes of this section, the term "preventive measures" means actions which eliminate the reasonable likelihood of asbestos-containing material becoming damaged, deteriorated, or delaminated, or significantly damaged deteriorated, or delaminated (as the case may be) or which protect human health and the environment.

(7) The Administrator shall, not later than $\mathbf{3 0}$ days after enactment of this paragraph [enacted Nov. 28 , 1990], publish and distribute to all local education agencies and State Governors information or an advisory to-

(A) facilitate public understanding of the comparative risks associated with in-place management of asbestos-containing building materials and removals;

(B) promote the least burdensome response actions necessary to protect human health, safety, and the environment; and

(C) describe the circumstances in which asbestos removal is necessary to protect human health.

Such information or advisory shall be based on the best available scientific evidence and shall be revised, republished, and redistributed as appropriate, to reflect new scientific findings.

(e) Implementation.-The Administrator shall promulgate regulations requiring the implementation of response actions in school buildings under the authority of a local educational agency and, where appropriate, for the determination of when a response action is completed. Such regulations shall include standards for the education and protection of both workers and building occupants for the following phases of activity:

(1) Inspection.

(2) Response Action.

(3) Post-response action, including any periodic reinspection of asbestos-containing material and long-term surveillance activity.

(f) Operations and maintenance.-The Administrator shall promulgate regulations to require implementation of an operations and maintenance and repair program as described in chapter 3 of the "Guidance for Controlling Asbestos-Containing Materials in Buildings" for all friable asbestos-containing material in a school building under the authority of a local educational agency.

(g) Periodic surveillance.-The Administrator shall promulgate regulations to require the following:

(1) An identification of the location of friable and non-friable asbestos in a school building under the authority of a local educational agency.

(2) Provisions for surveillance and periodic reinspection of such friable and non-friable asbestos. 
(3) Provisions for education of school employees, including school service and maintenance personnel, about the location of and safety procedures with respect to such friable and non-friable asbestos.

(h) Transportation and disposal.-The Administrator shall promulgate regulations which prescribe standards for transportation and disposal of asbestos-containing waste material to protect human health and the environment. Such regulations shall include such provisions related to the manner in which transportation vehicles are loaded and unloaded as will assure the physical integrity of containers of asbestos-containing waste material.

(i) Management plans.-

(1) In general.-The Administrator shall promulgate regulations which require each local educational agency to develop an asbestos management plan for school buildings under its authority, to begin implementation of such plan within 990 days after the date of the enactment of this title [enacted Oct. 22, 1986], and to complete implementation of such plan in a timely fashion. The regulations shall require that each plan include the following elements, wherever relevant to the school building:

(A) An inspection statement describing inspection and response action activities carried out before the date of the enactment of this title [enacted Oct. 22, 1986].

(B) A description of the results of the inspection conducted pursuant to regulations under subsection (b), including a description of the specific areas inspected.

(C) A detailed description of measures to be taken to respond to any friable asbestos-containing material pursuant to the regulations promulgated under subsections (c), (d), and (e), including the location or locations at which a response action will be taken, the method or methods of response action to be used, and a schedule for beginning and completing response actions.

(D) A detailed description of any asbestos-containing material which remains in the school building once response actions are undertaken pursuant to the regulations promulgated under subsections (c), (d), and (e).

(E) A plan for periodic reinspection and long-term surveillance activities developed pursuant to regulations promulgated under subsection $(\mathrm{g})$, and a plan for operations and maintenance activities developed pursuant to regulations promulgated under subsection (f).

(F) With respect to the person or persons who inspected for asbestos-containing material and who will design or carry out response actions with respect to the friable asbestos-containing material, one of the following statements:

(i) If the State has adopted a contractor accreditation plan under section 206(b) [15 U.S.C. 2646(b)], a statement that the person (or persons) is accredited under such plan.

(ii) A statement that the local educational agency used (or will use) persons who have been accredited by another State which has adopted a contractor accreditation plan under section 206(b)

[15 U.S.C. 2646(b)] or is accredited pursuant to an Administrator-approved course under section 206(c) [15 U.S.C. 2646(c)].

(G) A list of the laboratories that analyzed any bulk samples of asbestos-containing material found in the school building or air samples taken to detect asbestos in the school building and a statement that each laboratory has been accredited pursuant to the accreditation program under section 206(d) [15 U.S.C. 2646(d)].

(H) With respect to each consultant who contributed to the management plan, the name of the consultant and one of the following statements:

(i) If the State has adopted a contractor accreditation plan under section 206(b) [15 U.S.C. 2646(b)], a statement that the consultant is accredited under such plan.

(ii) A statement that the contractor is accredited by another State which has adopted a contractor accreditation plan under section 206(b) [15 U.S.C. 2646(b)] or is accredited pursuant to an Administrator-approved course under section 206(c) [15 U.S.C. 2646(c)].

(I) An evaluation of resources needed to successfully complete response actions and carry out reinspection, surveillance, and operation and maintenance activities.

(2) Statement by contractor.-A local educational agency may require each management plan to contain a statement signed by an accredited asbestos contractor that such contractor has prepared or assisted in the preparation of such plan, or has reviewed such plan, and that such plan is in compliance with the applicable regulations and standards promulgated or adopted pursuant to this section and other applicable provisions of law. Such a statement may not be signed by a contractor who, in addition to preparing or assisting in preparing the management plan, also implements (or will implement) the management plan. 
(3) Warning labels.

(A) The regulations shall require that each local educational agency which has inspected for and discovered any asbestos-containing material with respect to a school building shall attach a warning label to any asbestos-containing material still in routine maintenance areas (such as boiler rooms) of the school building, including-

(i) friable asbestos-containing material which was responded to by a means other than removal, and

(ii) asbestos-containing material for which no response action was carried out.

(B) The warning label shall read, in print which is readily visible because of large size or bright color, as follows: "CAUTION: ASBESTOS, HAZARDOUS, DO NOT DISTURB WITHOUT PROPER TRAINING AND EQUIPMENT."

(4) Plan may be submitted in stages.-A local educational agency may submit a management plan in stages, with each submission of the agency covering only a portion of the school buildings under the agency's authority, if the agency determines that such action would expedite the identification and abatement of hazardous asbestos-containing material in the school buildings under the authority of the agency.

(5) Public availability.-A copy of the management plan developed under the regulations shall be available in the administrative offices of the local educational agency for inspection by the public, including teachers, other school personnel, and parents. The local educational agency shall notify parent, teacher, and employee organizations of the availability of such plan.

(6) Submission to state governor--Each plan developed under this subsection shall be submitted to the State Governor under section 205 [15 U.S.C. 2645].

(j) Changes in regulations.-Changes may be made in the regulations promulgated under this section only by rule in accordance with section 553 of title 5, United States Code. Any such change must protect human health and the environment.

(k) Changes in guidance document.-Any change made in the 'Guidance for Controlling Asbestos-Containing Material in Buildings' shall be made only by rule in accordance with section 553 of title 5, United States Code, unless a regulation described in this section dealing with the same subject matter is in effect. Any such change must protect human health and the environment.

(l) Treatment of Department of Defense schools.-

(1) Secretary to act in lieu of governor.-In the administration of this title, any function, duty, or other responsibility imposed on a Governor of a State shall be carried out by the Secretary of Defense with respect to any school operated under the defense dependents' education system provided for under the Defense Dependents' Education Act of 1978 (20 U.S.C. 921 et seq.).

(2) Regulations.-The Secretary of Defense, in cooperation with the Administrator, shall, to the extent feasible and consistent with the national security, take such action as may be necessary to provide for the identification, inspection, and management (including abatement) of asbestos in any building used by the Department of Defense as an overseas school for dependents of members of the Armed Forces. Such identification, inspection, and management (including abatement) shall, subject to the preceding sentence, be carried out in a manner comparable to the manner in which a local educational agency is required to carry out such activities with respect to a school building under this title.

(m) Waiver.-The Administrator, upon request by a Governor and after notice and comment and opportunity for a public hearing in the affected State, may waive some or all of the requirements of this section and section 204 [15 U.S.C. 2644] with respect to such State if it has established and is implementing a program of asbestos inspection and management that contains requirements that are at least as stringent as the requirements of this section and section 204 [15 U.S.C. 2644].

\section{Requirements If EPA Fails to Promulgate Regulations}

[15 U.S.C. 2644]

Sec. 204. (a) In general.-

(1) Failure to promulgate.-If the Administrator fails to promulgate within the prescribed period-

(A) regulations described in section 203(b) [15 U.S.C. 2643(b)] (relating to inspection);

(B) regulations described in section 203(c), (d), (e), (f), (g), and (i) [15 U.S.C. 2643(c), (d), (e), (f),

(g), (i)] (relating to responding to asbestos); or

(C) regulations described in section 203(h) [15 U.S.C. 2643(h)] (relating to transportation and disposal); each local educational agency shall carry out the requirements described in this section in 
subsection (b); subsections (c), (d), and (e); or subsection (f); respectively, in accordance with the Environmental Protection Agency's most current guidance document.

(2) Stay by court.-If the Administrator has promulgated regulations described in paragraph (1)(A), (B), or (C) within the prescribed period, but the effective date of such regulations has been stayed by a court for a period of more than 30 days, a local educational agency shall carry out the pertinent requirements described in this subsection in accordance with the Environmental Protection Agency's most current guidance document.

(3) Effective period.-The requirements of this section shall be in effect until such time as the Administrator promulgates the pertinent regulations or until the stay is lifted (as the case may be).

(b) Inspection.-

(1) Except as provided in paragraph (2), the local educational agency, within 540 days after the date of the enactment of this title [enacted Oct. 22, 1986], shall conduct an inspection for asbestos-containing material, using personnel accredited under section 206(b) [15 U.S.C. 2646(b)] or 206(c) [15 U.S.C. 2646(c)] and laboratories accredited under section 206(d) [15 U.S.C. 2646(d)], in each school building under its authority.

(2) The local educational agency may exclude from the inspection requirement in paragraph (1) any school building, or portion of a school building, if (A) an inspection of such school building (or portion) was completed before the date on which this section goes into effect, and (B) the inspection meets the inspection requirements of this section.

(c) Operation and maintenance.-The local educational agency shall, within 720 days after the date of the enactment of this title [enacted Oct. 22, 1986], develop and begin implementation of an operation and maintenance plan with respect to friable asbestos-containing material in a school building under its authority. Such plan shall provide for the education of school service and maintenance personnel about safety procedures with respect to asbestos-containing material, including friable asbestos-containing material.

(d) Management plan.-

(1) In general.-The local educational agency shall-

(A) develop a management plan for responding to asbestos-containing material in each school building under its authority and submit such plan to the Governor under section 205 [15 U.S.C. 2645] within 810 days after the date of the enactment of this title [enacted Oct. 22, 1986],

(B) begin implementation of such plan within 990 days after the date of the enactment of this title [enacted Oct. 22, 1986], and

(C) complete implementation of such plan in a timely fashion.

(2) Plan requirements.-The management plan shall-

(A) include the elements listed in section 203(i)(1) [15 U.S.C. 2641(i)(1)], including an inspection statement as described in paragraph (3) of this section,

(B) provide for the attachment of warning labels as described in section 203(i)(3) [15 U.S.C. 2641(i)(3)],

(C) be prepared in accordance with the most current guidance document,

(D) meet the standard described in paragraph (4) for actions described in that paragraph, and

(E) be submitted to the State Governor under section 205 [15 U.S.C. 2645].

(3) Inspection statement.-The local educational agency shall complete an inspection statement, covering activities carried out before the date of the enactment of this title [enacted Oct. 22, 1986], which meets the following requirements:

(A) The statement shall include the following information:

(i) The dates of inspection.

(ii) The name, address, and qualifications of each inspector.

(iii) A description of the specific areas inspected.

(iv) A list of the laboratories that analyzed any bulk samples of asbestos-containing material or air samples of asbestos found in any school building and a statement describing the qualifications of each laboratory.

(v) The results of the inspection.

(B) The statement shall state whether any actions were taken with respect to any asbestos-containing material found to be present, including a specific reference to whether any actions were taken in the boiler room of the building. If any such action was taken, the following items of information shall be included in the statement: 
(i) The location or locations at which the action was taken.

(ii) A description of the method of action.

(iii) The qualifications of the persons who conducted the action.

(4) Standard.-The ambient interior concentration of asbestos after the completion of actions described in the most current guidance document, other than the type of action described in sections 203(f) [15 U.S.C. 2643(f)] and subsection (c) of this section, shall not exceed the ambient exterior concentration, discounting any contribution from any local stationary source. Either a scanning electron microscope or a transmission electron microscope shall be used to determine the ambient interior concentration. In the absence of reliable measurements, the ambient exterior concentration shall be deemed to be-

(A) less than 0.003 fibers per cubic centimeter if a scanning electron microscope is used, and

(B) less than 0.005 fibers per cubic centimeter if a transmission electron microscope is used.

(5) Public availability.-A copy of the management plan shall be available in the administrative offices of the local educational agency for inspection by the public, including teachers, other school personnel, and parents. The local educational agency shall notify parent, teacher, and employee organizations of the availability of such plan.

(e) Building occupant protection.-The local educational agency shall provide for the protection of building occupants during each phase of activity described in this section.

(f) Transportation and disposal.- The local educational agency shall provide for the transportation and disposal of asbestos in accordance with the most recent version of the Environmental Protection Agency's "Asbestos Waste Management Guidance" (or any successor to such document).

\section{Submission to State Governor}

[15 U.S.C. 2645]

Sec. 205. (a) Submission.-Within 720 days after the date of the enactment of this title [enacted Oct. 22, 1986] (or within 810 days if there are no regulations under section 203(i)) [15 U.S.C. 2643(i)], a local educational agency shall submit a management plan developed pursuant to regulations promulgated under section 203(i) [15 U.S.C. 2643(i)] (or under section 204(d) [15 U.S.C. 2644(d)] if there are no regulations) to the Governor of the State in which the local educational agency is located.

(b) Governor requirements.-Within 360 days after the date of the enactment of this title [enacted Oct. 22, 1986], the Governor of each State-

(1) shall notify local educational agencies in the State of where to submit their management plans under this section, and

(2) may establish administrative procedures for reviewing management plans submitted under this section. If the Governor establishes procedures under paragraph (2), the Governor shall designate to carry out the reviews those State officials who are responsible for implementing environmental protection or other public health programs, or with authority over asbestos programs, in the State.

(c) Management plan review.-

(1) Review of plan.-The Governor may disapprove a management plan within 90 days after the date of receipt of the plan if the plan-

(A) does not conform with the regulations under section 203(i) [15 U.S.C. 2643(i)] (or with section 204(d) [15 U.S.C. 2644(d)] if there are no regulations),

(B) does not assure that contractors who are accredited pursuant to this title will be used to carry out the plan, or

(C) does not contain a response action schedule which is reasonable and timely, taking into account circumstances relevant to the speed at which the friable asbestos-containing material in the school buildings under the local educational agency's authority should be responded to, including human exposure to the asbestos while the friable asbestos-containing material remains in the school building, and the ability of the local educational agency to continue to provide educational services to the community.

(2) Revision of plan.--If the State Governor disapproves a plan, the State Governor shall explain in writing to the local educational agency the reasons why the plan was disapproved and the changes that need to be made in the plan. Within 30 days after the date on which notice is received of disapproval of its plan, the local educational agency shall revise the plan to conform with the State Governor's suggested changes. The Governor may extend the 30-day period for not more than 90 days.

(d) Deferral of submission.- 
(1) Request for deferral.--A local educational agency may request a deferral, to May 9, 1989, of the deadline under subsection (a). Upon approval of such a request, the deadline under subsection (a) is deferred until May 9, 1989, for the local educational agency which submitted the request. Such a request may cover one or more schools under the authority of the agency and shall include a list of all the schools covered by the request. A local educational agency shall file any such request with the State Governor by October 12, 1988, and shall include with the request either of the following statements:

(A) A statement-

(i) that the State in which the agency is located has requested from the Administrator, before June 1,1988 , a waiver under section 203(m) [15 U.S.C. 2643(m)]; and

(ii) that gives assurance that the local educational agency has carried out the notification and, in the case of a public school, public meeting required by paragraph (2).

(B) A statement, the accuracy of which is sworn to by a responsible official of the agency (by notarization or other means of certification), that includes the following with respect to each school for which a deferral is sought in the request:

(i) A statement that, in spite of the fact that the local educational agency has made a good faith effort to meet the deadline for submission of a management plan under subsection (a), the agency will not be able to meet the deadline. The statement shall include a brief explanation of the reasons why the deadline cannot be met.

(ii) A statement giving assurance that the local educational agency has made available for inspection by the public, at each school for which a deferral is sought in the request, at least one of the following documents:

(I) A solicitation by the local educational agency to contract with an accredited asbestos contractor for inspection or management plan development.

(II) A letter attesting to the enrollment of school district personnel in an Environmental Protection Agency-accredited training course for inspection and management plan development.

(III) Documentation showing that an analysis of suspected asbestos-containing material from the school is pending at an accredited laboratory.

(IV) Documentation showing that an inspection or management plan has been completed in at least one other school under the local educational agency's authority.

(iii) A statement giving assurance that the local educational agency has carried out the notification and, in the case of a public school, public meeting required by paragraph (2).

(iv) A proposed schedule outlining all significant activities leading up to submission of a management plan by May 9,1989 , including inspection of the school (if not completed at the time of the request) with a deadline of no later than December 22, 1988, for entering into a signed contract with an accredited asbestos contractor for inspection (unless such inspections are to be performed by school personnel), laboratory analysis of material from the school suspected of containing asbestos, and development of the management plan.

(2) Notification and public meeting.-Before filing a deferral request under paragraph (1), a local educational agency shall notify affected parent, teacher, and employee organizations of its intent to file such a request. In the case of a deferral request for a public school, the local educational agency shall discuss the request at a public meeting of the school board with jurisdiction over the school, and affected parent, teacher, and employee organizations shall be notified in advance of the time and place of such meeting.

(3) Response by Governor--

(A) Not later than 30 days after the date on which a Governor receives a deferral request under paragraph (1) from a local educational agency, the Governor shall respond to the local educational agency in writing by acknowledging whether the request is complete or incomplete. If the request is incomplete, the Governor shall identify in the response the items that are missing from the request.

(B) A local educational agency may correct any deficiencies in an incomplete deferral request and refile the request with the Governor. In any case in which the local educational agency decides to refile the request, the agency shall refile the request, and the Governor shall respond to such refiled request in the manner described in subparagraph (A), no later than 15 days after the local educational agency has received a response from the Governor under subparagraph (A). 
(C) Approval of a deferral request under this subsection occurs only upon the receipt by a local educational agency of a written acknowledgment from the Governor that the agency's deferral request is complete.

(4) Submission and review of plan.-A local educational agency whose deferral request is approved shall submit a management plan to the Governor not later than May 9, 1989. Such management plan shall include a copy of the deferral request and the statement accompanying such request. Such management plan shall be reviewed in accordance with subsection (c), except that the Governor may extend the 30-day period for revision of the plan under subsection (c)(2) for only an additional 30 days (for a total of 60 days).

(5) Implementation of plan.-The approval of a deferral request from a local educational agency shall not be considered to be a waiver or exemption from the requirement under section 203(i) [15 U.S.C. 2643(i)] for the local educational agency to begin implementation of its management plan by July $9,1989$.

(6) EPA notice.-

(A) Not later than 15 days after the date of the enactment of this subsection [enacted July 18, 1988], the Administrator shall publish in the Federal Register the following:

(i) A notice describing the opportunity to file a request for deferral under this subsection.

(ii) A list of the State offices (including officials (if available) in each State as designated under subsection (b)) with which deferral requests should be filed.

(B) As soon as practicable, but in no event later than 30 days, after the date of the enactment of this subsection [enacted July 18, 1988], the Administrator shall mail a notice describing the opportunity to file a request for deferral under this subsection to each local educational agency and to each State office in the list published under subparagraph (A).

(e) Status reports.-

(1) Not later than December 31, 1988, the Governor of each State shall submit to the Administrator a written statement on the status of management plan submissions and deferral requests by local educational agencies in the State. The statement shall be made available to local educational agencies in the State and shall contain the following:

(A) A list containing each local educational agency that submitted a management plan by October 12 , 1988.

(B) A list containing each local educational agency whose deferral request was approved.

(C) A list containing each local educational agency that failed to submit a management plan by October

12,1988 , and whose deferral request was disapproved.

(D) A list containing each local educational agency that failed to submit a management plan by October

12,1988 , and did not submit a deferral request.

(2) Not later than December 31, 1989, the Governor of each State shall submit to the Administrator an updated version of the written statement submitted under paragraph (1). The statement shall be made available to local educational agencies in the State and shall contain the following:

(A) A list containing each local educational agency whose management plan was submitted and not disapproved as of October 9, 1989.

(B) A list containing each local educational agency whose management plan was submitted and disapproved, and which remains disapproved, as of October 9, 1989.

(C) A list containing each local educational agency that submitted a management plan after May 9 , 1989, and before October 10, 1989.

(D) A list containing each local educational agency that failed to submit a management plan as of October 9, 1989.

\section{Contractor and Laboratory Accreditation}

[15 U.S.C. 2646]

Sec. 206. (a) Contractor and laboratory accreditation.-A person may not-

(1) inspect for asbestos-containing material in a school building under the authority of a local educational agency or in a public or commercial building,

(2) prepare a management plan for such a school, or

(3) design or conduct response actions, other than the type of action described in sections 203(f) [15 U.S.C. 2643(f)] and 204(c) [15 U.S.C. 2644(c)], with respect to friable asbestos-containing material in such a school or in a public or commercial building, unless such person is accredited by a State under subsection (b) or is accredited pursuant to an Administrator-approved course under subsection (c). 
(b) Accreditation by state.-

(1) Model plan.-

(A) Persons to be accredited.-Within 180 days after the date of the enactment of this title [enacted Oct. 22, 1986], the Administrator, in consultation with affected organizations, shall develop a model contractor accreditation plan for States to give accreditation to persons in the following categories:

(i) Persons who inspect for asbestos-containing material in school buildings under the authority of a local educational agency or in public or commercial buildings.

(ii) Persons who prepare management plans for such schools.

(iii) Persons who design or carry out response actions, other than the type of action described in sections 203(f) [15 U.S.C. 2643(f)] and 204(c) [15 U.S.C. 2644(c)], with respect to friable asbestos-containing material in such schools or in public or commercial buildings.

(B) Plan requirements.-The plan shall include a requirement that any person in a category listed in paragraph (1) achieve a passing grade on an examination and participate in continuing education to stay informed about current asbestos inspection and response action technology. The examination shall demonstrate the knowledge of the person in areas that the Administrator prescribes as necessary and appropriate in each of the categories. Such examinations may include requirements for knowledge in the following areas:

(i) Recognition of asbestos-containing material and its physical characteristics.

(ii) Health hazards of asbestos and the relationship between asbestos exposure and disease.

(iii) Assessing the risk of asbestos exposure through a knowledge of percentage weight of asbestos-containing material, friability, age, deterioration, location and accessibility of materials, and advantages and disadvantages of dry and wet response action methods.

(iv) Respirators and their use, care, selection, degree of protection afforded, fitting, testing, and maintenance and cleaning procedures.

(v) Appropriate work practices and control methods, including the use of high efficiency particle absolute vacuums, the use of amended water, and principles of negative air pressure equipment use and procedures.

(vi) Preparing a work area for response action work, including isolating work areas to prevent bystander or public exposure to asbestos, decontamination procedures, and procedures for dismantling work areas after completion of work.

(vii) Establishing emergency procedures to respond to sudden releases.

(viii) Air monitoring requirements and procedures.

(ix) Medical surveillance program requirements.

(x) Proper asbestos waste transportation and disposal procedures.

(xi) Housekeeping and personal hygiene practices, including the necessity of showers, and procedures to prevent asbestos exposure to an employee's family.

(2) State adoption of plan.--Each State shall adopt a contractor accreditation plan at least as stringent as the model plan developed by the Administrator under paragraph (1), within 180 days after the commencement of the first regular session of the legislature of such State which is convened following the date on which the Administrator completes development of the model plan. In the case of a school operated under the defense dependents' education system provided for under the Defense Dependents' Education Act of 1978 (20 U.S.C. 921 et seq.), the Secretary of Defense shall adopt a contractor accreditation plan at least as stringent as that model.

(c) Accreditation by administrator-approved course.

(1) Course approval.-Within 180 days after the date of the enactment of this title [enacted Oct. 22, 1986], the Administrator shall ensure that any Environmental Protection Agency-approved asbestos training course is consistent with the model plan (including testing requirements) developed under subsection (b). A contractor may be accredited by taking and passing such a course.

(2) Treatment of persons with previous EPA asbestos training. A person who-

(A) completed an Environmental Protection Agency-approved asbestos training course before the date of the enactment of this title [enacted Oct. 22, 1986], and

(B) passed (or passes) an asbestos test either before or after the date of the enactment of this title [enacted Oct. 22, 1986], may be accredited under paragraph (1) if the Administrator determines that the course and test are equivalent to the requirements of the model plan developed under subsection (b). If the Administrator so determines, the person shall be considered accredited for the purposes of 
this title until a date that is one year after the date on which the State in which such person is employed establishes an accreditation program pursuant to subsection (b).

(3) Lists of courses.-The Administrator, in consultation with affected organizations, shall publish (and revise as necessary)-

(A) a list of asbestos courses and tests in effect before the date of the enactment of this title [enacted Oct. 22, 1986], which qualify for equivalency treatment under paragraph (2), and

(B) a list of asbestos courses and tests which the Administrator determines under paragraph (1) are consistent with the model plan and which will qualify a contractor for accreditation under such paragraph.

(d) Laboratory accreditation.-

(1) The Administrator shall provide for the development of an accreditation program for laboratories by the National Bureau of Standards in accordance with paragraph (2). The Administrator shall transfer such funds as are necessary to the National Bureau of Standards to carry out such program.

(2) The National Bureau of Standards, upon request by the Administrator, shall, in consultation with affected organizations-

(A) within 360 days after the date of the enactment of this title [enacted Oct. 22, 1986], develop an accreditation program for laboratories which conduct qualitative and semi-quantitative analyses of bulk samples of asbestos-containing material, and

(B) within 720 days after the date of the enactment of this title [enacted Oct. 22, 1986], develop an accreditation program for laboratories which conduct analyses of air samples of asbestos from school buildings under the authority of a local educational agency.

(3) A laboratory which plans to carry out any such analysis shall comply with the requirements of the accreditation program.

(e) Financial assistance contingent on use of accredited persons.-

(1) A school which is an applicant for financial assistance under section 505 of the Asbestos School Hazard Abatement Act of 1984 (Public Law 98-377; 20 U.S.C. 4011 et seq.) is not eligible for such assistance unless the school, in carrying out the requirements of this title-

(A) uses a person (or persons)-

(i) who is accredited by a State which has adopted an accreditation plan based on the model plan developed under subsection (b), or

(ii) who is accredited pursuant to an Administrator-approved course under subsection (c), and

(B) uses a laboratory (or laboratories) which is accredited under the program developed under subsection (d).

(2) This subsection shall apply to any financial assistance provided under the Asbestos School Hazard Abatement Act of 1984 for activities performed after the following dates:

(A) In the case of activities performed by persons, after the date which is one year after the date of the enactment of this title [enacted Oct. 22, 1986].

(B) In the case of activities performed by laboratories, after the date which is 180 days after the date on which a laboratory accreditation program is completed under subsection (d).

(f) List of EPA-approved courses.-Not later than August 31, 1988, and every three months thereafter until August 31, 1991, the Administrator shall publish in the Federal Register a list of all Environmental Protection Agency-approved asbestos training courses for persons to achieve accreditation in each category described in subsection (b)(1)(A) and for laboratories to achieve accreditation. The Administrator may continue publishing such a list after August 31, 1991, at such times as the Administrator considers it useful. The list shall include the name and address of each approved trainer and, to the extent available, a list of all the geographic sites where training courses will take place. The Administrator shall provide a copy of the list to each State official on the list published by the Administrator under section 205(d)(6) [15 U.S.C. 2645(d)(6)] and to each regional office of the Environmental Protection Agency.

\section{Enforcement}

[15 U.S.C. 2647]

Sec. 207. (a) Penalties.-Any local educational agency-

(1) which fails to conduct an inspection pursuant to regulations under section 203(b) [15 U.S.C. 2643(b)] or under section 204(b) [15 U.S.C. 2644(b)], 
(2) which knowingly submits false information to the Governor regarding any inspection pursuant to regulations under section 203(i) [15 U.S.C. 2643(i)] or knowingly includes false information in any inspection statement under section 204(d)(3) [15 U.S.C. 2644(d)(3)],

(3) which fails to develop a management plan pursuant to regulations under section 203(i) [15 U.S.C. 2643(i)] or under section 204(d) [15 U.S.C. 2644(d)], is liable for a civil penalty of not more than $\$ 5,000$ for each day during which the violation continues. Any civil penalty under this subsection shall be assessed and collected in the same manner, and subject to the same provisions, as in the case of civil penalties assessed and collected under section 16 [15 U.S.C. 2615]. For purposes of this subsection, a "violation" means a failure to comply with respect to a single school building. The court shall order that any civil penalty collected under this subsection be used by the local educational agency for purposes of complying with this title. Any portion of a civil penalty remaining unspent after compliance by a local educational agency is completed shall be deposited into the Asbestos Trust Fund established by section 5 of the Asbestos Hazard Emergency Response Act of 1986 [20 U.S.C. 4022].

(4) which carries out any activity prohibited by section 215 [15 U.S.C. 2655], or

(5) which knowingly submits false information to the Governor regarding a deferral request under section 205(d) [15 U.S.C. 2645(d)][.]

(b) Relationship to Title I.-A local educational agency is not liable for any civil penalty under title I of this Act [15 U.S.C. 2601 et seq.] for failing or refusing to comply with any rule promulgated or order issued under this title.

(c) Enforcement considerations.-

(1) In determining the amount of a civil penalty to be assessed under subsection (a) against a local educational agency, the Administrator shall consider-

(A) the significance of the violation;

(B) the culpability of the violator, including any history of previous violations under this Act [15 U.S.C.

2601 et seq.];

(C) the ability of the violator to pay the penalty; and

(D) the ability of the violator to continue to provide educational services to the community.

(2) Any action ordered by a court in fashioning relief under section 20 [15 U.S.C. 2619] shall be consistent with regulations promulgated under section 203 [15 U.S.C. 2643] (or with the requirements of section 204 [15 U.S.C. 2644] if there are no regulations).

(d) Citizen complaints. - Any person may file a complaint with the Administrator or with the Governor of the State in which the school building is located with respect to asbestos-containing material in a school building. If the Administrator or Governor receives a complaint under this subsection containing allegations which provide a reasonable basis to believe that a violation of this Act [15 U.S.C. 2601 et seq.] has occurred, the Administrator or Governor shall investigate and respond (including taking enforcement action where appropriate) to the complaint within a reasonable period of time.

(e) Citizen petitions.-

(1) Any person may petition the Administrator to initiate a proceeding for the issuance, amendment, or repeal of a regulation or order under this title.

(2) Such petition shall be filed in the principal office of the Administrator and shall set forth the facts which it is claimed establish that it is necessary to issue, amend, or repeal a regulation or order under this title.

(3) The Administrator may hold a public hearing or may conduct such investigation or proceeding as the Administrator deems appropriate in order to determine whether or not such petition should be granted.

(4) Within 90 days after filing of a petition described in paragraph (1), the Administrator shall either grant or deny the petition. If the Administrator grants such petition, the Administrator shall promptly commence an appropriate proceeding in accordance with this title. If the Administrator denies such petition, the Administrator shall publish in the Federal Register the Administrator's reasons for such denial. The granting or denial of a petition under this subsection shall not affect any deadline or other requirement of this title.

(f) Citizen civil actions with respect to EPA regulations.-

(1) Any person may commence a civil action without prior notice against the Administrator to compel the Administrator to meet the deadlines in section 203 [15 U.S.C. 2643] for issuing advanced notices of proposed rulemaking, proposing regulations, and promulgating regulations. Any such action shall be brought in the district court of the United States for the District of Columbia. 
(2) In any action brought under paragraph (1) in which the court finds the Administrator to be in violation of any deadline in section 203 [15 U.S.C. 2643] the court shall set forth a schedule for promulgating the regulations required by section 203 [15 U.S.C. 2643], and shall order the Administrator to comply with such schedule. The court may extend any deadline (which has not already occurred) in section 204(b), 204(c), or 204(d) [15 U.S.C. 2644(b), (c), or (d)] for a period of not more than 6 months, if the court-ordered schedule will result in final promulgation of the pertinent regulations within the extended period. Such deadline extensions may not be granted by the court beginning 720 days after the date of enactment of this title [enacted Oct. 22, 1986].

(3) Section 20 of this Act [15 U.S.C. 2619] shall apply to civil actions described in this subsection, except to the extent inconsistent with this subsection.

(g) Contractor penalties.-Any contractor who-

(1) inspects for asbestos-containing material in a school, public or commercial building;

(2) designs or conducts response actions which respect to friable asbestos-containing material in a school, public or commercial building; or

(3) employs individuals to conduct response actions with respect to friable asbestos-containing material in a school, public or commercial building; and who fails to obtain the accreditation under section 206 of this Act [15 U.S.C. 2646], or in the case of employees to require or provide for the accreditation required, is liable for a civil penalty of not more than $\$ 5,000$ for each day during which the violation continues, unless such contractor is a direct employee of the Federal Government.

\section{Emergency Authority}

[15 U.S.C. 2648]

Sec. 208. (a) Emergency action.-

(1) Authority.-Whenever-

(A) the presence of airborne asbestos or the condition of friable asbestos-containing material in a school building governed by a local educational agency poses an imminent and substantial endangerment to human health or the environment, and

(B) the local educational agency is not taking sufficient action (as determined by the Administrator or the Governor) to respond to the airborne asbestos or friable asbestos-containing material, the Administrator or the Governor of a State is authorized to act to protect human health or the environment.

(2) Limitations on governor action.-The Governor of a State shall notify the Administrator within a reasonable period of time before the Governor plans to take an emergency action under this subsection. After such notification, if the Administrator takes an emergency action with respect to the same hazard, the Governor may not carry out (or continue to carry out, if the action has been started) the emergency action.

(3) Notification.-The following notification shall be provided before an emergency action is taken under this subsection:

(A) In the case of a Governor taking the action, the Governor shall notify the local educational agency concerned.

(B) In the case of the Administrator taking the action, the Administrator shall notify both the local educational agency concerned and the Governor of the State in which such agency is located.

(4) Cost recovery.-The Administrator or the Governor of a State may seek reimbursement for all costs of an emergency action taken under this subsection in the United States District Court for the District of Columbia or for the district in which the emergency action occurred. In any action seeking reimbursement from a local educational agency, the action shall be brought in the United States District Court for the district in which the local educational agency is located.

(b) Injunctive relief.-Upon receipt of evidence that the presence of airborne asbestos or the condition of friable asbestos-containing material in a school building governed by a local educational agency poses an imminent and substantial endangerment to human health or the environment-

(1) the Administrator may request the Attorney General to bring suit, or

(2) the Governor of a State may bring suit, to secure such relief as may be necessary to respond to the hazard. The district court of the United States in the district in which the response will be carried out shall have jurisdiction to grant such relief, including injunctive relief. 
State and Federal Law

[15 U.S.C. 2649]

Sec. 209. (a) No preemption.-Nothing in this title shall be construed, interpreted, or applied to preempt, displace, or supplant any other State or Federal law, whether statutory or common.

(b) Cost and damage awards.- Nothing in this title or any standard, regulation, or requirement promulgated pursuant to this title shall be construed or interpreted to preclude any court from awarding costs and damages associated with the abatement, including the removal, of asbestos-containing material, or a portion of such costs, at any time prior to the actual date on which such material is removed.

(c) State may establish more requirements.-Nothing in this title shall be construed or interpreted as preempting a State from establishing any additional liability or more stringent requirements with respect to asbestos in school buildings within such State.

(d) No federal cause of action.-Nothing in this title creates a cause of action or in any other way increases or diminishes the liability of any person under any other law.

(e) Intent of Congress.-It is not the intent of Congress that this title or rules, regulations, or orders issued pursuant to this title be interpreted as influencing, in either the plaintiff's or defendant's favor, the disposition of any civil action for damages relating to asbestos. This subsection does not affect the authority of any court to make a determination in an adjudicatory proceeding under applicable State law with respect to the admission into evidence or any other use of this title or rules, regulations, or orders issued pursuant to this title.

Asbestos Contractors and Local Educational Agencies

[15 U.S.C. 2650]

Sec. 210. (a) Study-

(1) General requirement.-The Administrator shall conduct a study on the availability of liability insurance and other forms of assurance against financial loss which are available to local educational agencies and asbestos contractors with respect to actions required under this title. Such study shall examine the following:

(A) The extent to which liability insurance and other forms of assurance against financial loss are available to local educational agencies and asbestos contractors.

(B) The extent to which the cost of insurance or other forms of assurance against financial loss has increased and the extent to which coverage has become less complete.

(C) The extent to which any limitation in the availability of insurance or other forms of assurance against financial loss is the result of factors other than standards of liability in applicable law.

(D) The extent to which the existence of the regulations required by subsections (c) and (d) of section

203 [15 U.S.C. 2643(c), (d)] and the accreditation of contractors under section 206 [15 U.S.C. 2646] has affected the availability or cost of insurance or other forms of assurance against financial loss.

(E) The extent to which any limitation on the availability of insurance or other forms of assurance against financial loss is inhibiting inspections for asbestos-containing material or the development or implementation of management plans under this title.

(F) Identification of any other impediments to the timely completion of inspections or the development and implementation of management plans under this title.

(2) Interim report.- Not later than April 1, 1988, the Administrator shall submit to the Congress an interim report on the progress of the study required by this subsection, along with preliminary findings based on information collected to that date.

(3) Final report.-Not later than October 1, 1990, the Administrator shall submit to the Congress a final report on the study required by this subsection, including final findings based on the information collected.

(b) State action On the basis of the interim report or the final report of the study required by subsection (a), a State may enact or amend State law to establish or modify a standard of liability for local educational agencies or asbestos contractors with respect to actions required under this title. 
Public Protection

[15 U.S.C. 2651]

Sec. 211. (a) Public protection.-No State or local educational agency may discriminate against a person in any way, including firing a person who is an employee, because the person provided information relating to a potential violation of this title to any other person, including a State or the Federal Government.

(b) Labor department review.-Any public or private employee or representative of employees who believes he or she has been fired or otherwise discriminated against in violation of subsection (a) may within 90 days after the alleged violation occurs apply to the Secretary of Labor for a review of the firing or alleged discrimination. The review shall be conducted in accordance with section 11(c) of the Occupational Safety and Health Act [29 U.S.C. 660(c)].

\section{Asbestos Ombudsman}

[15 U.S.C. 2652]

$\mathbf{S}$ the duties described in subsection (b).

(b) Duties.-The duties of the Asbestos Ombudsman are-

(1) to receive complaints, grievances, and requests for information submitted by any person with respect to any aspect of this title,

(2) to render assistance with respect to the complaints, grievances, and requests received, and

(3) to make such recommendations to the Administrator as the Ombudsman considers appropriate.

EPA Study of Asbestos-Containing Material in Public Buildings

[15 U.S.C. 2653]

Sec. 213. Within 360 days after the date of the enactment of this title [enacted Oct. 22, 1986], the Administrator shall conduct and submit to the Congress the results of a study which shall-

(1) assess the extent to which asbestos-containing materials are present in public and commercial buildings;

(2) assess the condition of asbestos-containing material in commercial buildings and the likelihood that persons occupying such buildings, including service and maintenance personnel, are, or may be, exposed to asbestos fibers;

(3) consider and report on whether public and commercial buildings should be subject to the same inspection and response action requirements that apply to school buildings;

(4) assess whether existing Federal regulations adequately protect the general public, particularly abatement personnel, from exposure to asbestos during renovation and demolition of such buildings; and

(5) include recommendations that explicitly address whether there is a need to establish standards for, and regulate asbestos exposure in, public and commercial buildings.

Transition Rules

[15 U.S.C. 2654]

Sec. 214. Any regulation of the Environmental Protection Agency under title I [15 U.S.C. 2601 et seq.] which is inconsistent with this title shall not be in effect after the date of the enactment of this title [enacted Oct. 22, 1986]. Any advanced notice of proposed rulemaking, any proposed rule, and any regulation of the Environmental Protection Agency in effect before the date of the enactment of this title [enacted Oct. 22, 1986] which is consistent with the regulations required under section 203 [15 U.S.C. 2643] shall remain in effect and may be used to meet the requirements of section 203 [15 U.S.C. 2643], except that any such regulation shall be enforced under this Act [15 U.S.C. 2601 et seq.].

\section{Worker Protection}

[15 U.S.C. 2655]

Sec. 215. (a) Prohibition on certain activities.-Until the local educational agency with authority over a school has submitted a management plan (for the school) which the State Governor has not disapproved as of the end of the period for review and revision of the plan under section 205 [15 U.S.C. 2645], the local educational agency may not do either of the following in the school: 
(1) Perform, or direct an employee to perform, renovations or removal of building materials, except emergency repairs, in the school, unless-

(A) the school is carrying out work under a grant awarded under section 505 of the Asbestos School Hazard Abatement Act of 1984 [20 U.S.C. 4014]; or

(B) an inspection that complies with the requirements of regulations promulgated under section 203 [15 U.S.C. 2643] has been carried out in the school and the agency complies with the following sections of title 40 of the Code of Federal Regulations:

(i) Paragraphs (g), (h), and (i) of section 763.90 (response actions).

(ii) Appendix $\mathrm{D}$ to subpart $\mathrm{E}$ of part 763 (transport and disposal of asbestos waste).

(2) Perform, or direct an employee to perform, operations and maintenance activities in the school, unless the agency complies with the following sections of title 40 of the Code of Federal Regulations:

(A) Section 763.91 (operations and maintenance), including appendix B to subpart E of part 763.

(B) Paragraph (a)(2) of section 763.92 (training and periodic surveillance).

(b) Employee training and equipment.-Any school employee who is directed to conduct emergency repairs involving any building material containing asbestos or suspected of containing asbestos, or to conduct operations and maintenance activities, in a school-

(1) shall be provided the proper training to safely conduct such work in order to prevent potential exposure

to asbestos; and

(2) shall be provided the proper equipment and allowed to follow work practices that are necessary to safely conduct such work in order to prevent potential exposure to asbestos.

(c) Definition of emergency repair--For purposes of this section, the term "emergency repair" means a repair in a school building that was not planned and was in response to a sudden, unexpected event that threatens either-

(1) the health or safety of building occupants; or

(2) the structural integrity of the building.

$$
\text { Training Grants }
$$

[15 U.S.C. 2656]

Sec. 216. (a) Grants.-The Administrator is authorized to award grants under this section to nonprofit organizations that demonstrate experience in implementing and operating health and safety asbestos training and education programs for workers who are or will be engaged in asbestos-related activities (including State and local governments, colleges and universities, joint labor-management trust funds, and nonprofit government employee organizations) to establish and, or, operate asbestos training programs on a not-for-profit basis. Applications for grants under this subsection shall be submitted in such form and manner, and contain such information, as the Administrator prescribes.

(b) Authorization. - Of such sums as are authorized to be appropriated pursuant to section 512(a) of the Asbestos School Hazard Abatement Act of 1984 (20 U.S.C. 4011 et seq.) for the fiscal years 1991, 1992, 1993 , 1994 , and 1995 , not more than $\$ 5,000,000$ are authorized to be appropriated to carry out this section in each such fiscal year.

\section{TITLE III-INDOOR RADON ABATEMENT}

\section{National Goal}

[15 U.S.C. 2661]

Sec. 301. The national long-term goal of the United States with respect to radon levels in buildings is that the air within buildings in the United States should be as free of radon as the ambient air outside of buildings.

\section{Definitions}

[15 U.S.C. 2662]

Sec. 302. For purposes of this title [15 U.S.C. 2661 et seq.]:

(1) The term "local educational agency" means-

(A) any local educational agency as defined in section 198 of the Elementary and Secondary Education Act of 1965 (20 U.S.C. 3381);

(B) the owner of any nonprofit elementary or secondary school building; and 
(C) the governing authority of any school operated pursuant to section 6 of the Act of September 30, 1950 (64 Stat. 1107 [20 U.S.C. 241]), relating to impact aid for children who reside on Federal property. (2) The term "nonprofit elementary or secondary school" has the meaning given such term by section 202(8) [15 U.S.C. 2642(8)].

(3) The term "radon" means the radioactive gaseous element and its short-lived decay products produced by the disintegration of the element radium occurring in air, water, soil, or other media.

(4) The term "school building" has the meaning given such termby section 202(13) [15 U.S.C. 2642(13)].

\section{EPA Citizen's Guide}

[15 U.S.C. 2662]

Sec. 303. (a) Publication.-In order to make continuous progress toward the long-term goal established in section 301 of this title [15 U.S.C. 2661], the Administrator of the Environmental Protection Agency shall, not later than June 1,1989, publish and make available to the public an updated version of its document titled "A Citizen's Guide to Radon". The Administrator shall revise and republish the guide as necessary thereafter.

(b) Information included.-

(1) Action levels.-The updated citizen's guide published as provided in subsection (a) shall include a description of a series of action levels indicating the health risk associated with different levels of radon exposure.

(2) Other information.-The updated citizen's guide shall also include information with respect to each of the following:

(A) The increased health risk associated with the exposure of potentially sensitive populations to different levels of radon.

(B) The increased health risk associated with the exposure to radon of persons engaged in potentially risk-increasing behavior.

(C) The cost and technological feasibility of reducing radon concentrations within existing and new buildings.

(D) The relationship between short-term and long-term testing techniques and the relationship between

(i) measurements based on both such techniques, and (ii) the actions levels set forth as provided in paragraph (1).

(E) Outdoor radon levels around the country.

Model Construction Standards and Techniques

[15 U.S.C. 2664]

Sec. 304. The Administrator of the Environmental Protection Agency shall develop model construction standards and techniques for controlling radon levels within new buildings. To the maximum extent possible, these standards and techniques should be developed with the assistance of organizations involved in establishing national building construction standards and techniques. The Administrator shall make a draft of the document containing the model standards and techniques available for public review and comment. The model standards and techniques shall provide for geographic differences in construction types and materials, geology, weather, and other variables that may affect radon levels in new buildings. The Administrator shall make final model standards and techniques available to the public by June 1,1990. The Administrator shall work to ensure that organizations responsible for developing national model building codes, and authorities which regulate building construction within States or political subdivisions within States, adopt the Agency's model standards and techniques.

Technical Assistance to States for Radon Programs

[15 U.S.C. 2665]

Sec. 305. (a) Required activities.-The Administrator (or another Federal department or agency designated by the Administrator) shall develop and implement activities designed to assist State radon programs. These activities may include, but are not limited to, the following:

(1) Establishment of a clearinghouse of radon related information, including mitigation studies, public information materials, surveys of radon levels, and other relevant information.

(2) Operation of a voluntary proficiency program for rating the effectiveness of radon measurement devices and methods, the effectiveness of radon mitigation devices and methods, and the effectiveness of private 
firms and individuals offering radon-related architecture, design, engineering, measurement, and mitigation services. The proficiency program under this subparagraph shall be in operation within one year after the date of the enactment of this section [enacted Oct. 28, 1988].

(3) Design and implementation of training seminars for State and local officials and private and professional firms dealing with radon and addressing topics such as monitoring, analysis, mitigation, health effects, public information, and program design.

(4) Publication of public information materials concerning radon health risks and methods of radon mitigation.

(5) Operation of cooperative projects between the Environmental Protection Agency's Radon Action Program and the State's radon program. Such projects shall include the Home Evaluation Program, in which the Environmental Protection Agency evaluates homes and States demonstrate mitigation methods in these homes. To the maximum extent practicable, consistent with the objectives of the evaluation and demonstration, homes of low-income persons should be selected for evaluation and demonstration.

(6) Demonstration of radon mitigation methods in various types of structures and in various geographic settings and publication of findings. In the case of demonstration of such methods in homes, the Administrator should select homes of low-income persons, to the maximum extent practicable and consistent with the objectives of the demonstration.

(7) Establishment of a national data base with data organized by State concerning the location and amounts of radon.

(8) Development and demonstration of methods of radon measurement and mitigation that take into account unique characteristics, if any, of nonresidential buildings housing child care facilities.

(b) Discretionary assistance.-Upon request of a State, the Administrator (or another Federal department or agency designated by the Administrator) may provide technical assistance to such State in development or implementation of programs addressing radon. Such assistance may include, but is not limited to, the following:

(1) Design and implementation of surveys of the location and occurrence of radon within a State.

(2) Design and implementation of public information and education programs.

(3) Design and implementation of State programs to control radon in existing or new structures.

(4) Assessment of mitigation alternatives in unusual or unconventional structures.

(5) Design and implementation of methods for radon measurement and mitigation for nonresidential buildings housing child care facilities.

(c) Information provided to professional organizations.- The Administrator, or another Federal department or agency designated by the Administrator, shall provide appropriate information concerning technology and methods of radon assessment and mitigation to professional organizations representing private firms involved in building design, engineering, and construction.

(d) Plan.-Within 9 months after the date of the enactment of this section [enacted Oct. 28, 1988] and annually thereafter, the Administrator shall submit to Congress a plan identifying assistance to be provided under this section and outlining personnel and financial resources necessary to implement this section. Prior to submission to Congress, this plan shall be reviewed by the advisory groups provided for in section 403 (c) of the Superfund Amendments and Reauthorization Act of 1986 (42 U.S.C. 7401 note).

(e) Proficiency rating program and training seminar.-

(1) Authorization.-There is authorized to be appropriated not more than $\$ 1,500,000$ for the purposes of initially establishing the proficiency rating program under subsection $(a)(2)$ and the training seminars under subsection (a)(3).

(2) Charge imposed.-To cover the operating costs of such proficiency rating program and training seminars, the Administrator shall impose on persons applying for a proficiency rating and on private and professional firms participating in training seminars such charges as may be necessary to defray the costs of the program or seminars. No such charge may be imposed on any State or local government.

(3) Special account.-Funds derived from the charges imposed under paragraph (2) shall be deposited in a special account in the Treasury. Amounts in the special account are authorized to be appropriated only for purposes of administering such proficiency rating program or training seminars or for reimbursement of funds appropriated to the Administrator to initially establish such program or seminars.

(4) Reimbursement of General Fund.-During the first three years of the program and seminars, the Administrator shall make every effort, consistent with the goals and successful operation of the program and seminars, to set charges imposed under paragraph (2) so that an amount in excess of operation costs 
is collected. Such excess amount shall be used to reimburse the General Fund of the Treasury for the full amount appropriated to initially establish the program and seminars.

(5) Research.-The Administrator shall, in conjunction with other Federal agencies, conduct research to develop, test, and evaluate radon and radon progeny measurement methods and protocols. The purpose of such research shall be to assess the ability of those methods and protocols to accurately assess exposure to radon progeny. Such research shall include-

(A) conducting comparisons among radon and radon progeny measurement techniques;

(B) developing measurement protocols for different building types under varying operating conditions; and

(C) comparing the exposures estimated by stationary monitors and protocols to those measured by personal monitors, and issue guidance documents that-

(i) provide information on the results of research conducted under this paragraph; and

(ii) describe model State radon measurement and mitigation programs.

(6) Mandatory proficiency testing program study.-

(A) The Administrator shall conduct a study to determine the feasibility of establishing a mandatory proficiency testing program that would require that-

(i) any product offered for sale, or device used in connection with a service offered to the public, for the measurement of radon meets minimum performance criteria; and

(ii) any operator of a device, or person employing a technique, used in connection with a service offered to the public for the measurement of radon meets a minimum level of proficiency.

(B) The study shall also address procedures for-

(i) ordering the recall of any product sold for the measurement of radon which does not meet minimum performance criteria;

(ii) ordering the discontinuance of any service offered to the public for the measurement of radon which does not meet minimum performance criteria; and

(iii) establishing adequate quality assurance requirements for each company offering radon measurement services to the public to follow. The study shall identify enforcement mechanisms necessary to the success of the program. The Administrator shall report the findings of the study with recommendations to Congress by March 1, 1991.

(7) User fee.-In addition to any charge imposed pursuant to paragraph (2), the Administrator shall collect user fees from persons seeking certification under the radon proficiency program in an amount equal to $\$ 1,500,000$ to cover the Environmental Protection Agency's cost of conducting research pursuant to paragraph (5) for each of the fiscal years 1991, 1992, 1993, 1994, and 1995. Such funds shall be deposited in the account established pursuant to paragraph (3).

(f) Authorization.-

(1) There is authorized to be appropriated for the purposes of carrying out sections 303, 304 [15 U.S.C. 2663,2664 ], and this section an amount not to exceed $\$ 3,000,000$ for each of fiscal years 1989,1990 , and 1991.

(2) No amount appropriated under the subsection may be used by the Environmental Protection Agency to administer the grant program under section 306 [15 U.S.C. 2666].

(3) No amount appropriated under this subsection may be used to cover the costs of the proficiency rating program under subsection (a)(2).

\section{Grant Assistance to States for Radon Programs}

[15 U.S.C. 2666]

Sec. 306. (a) In general.-For each fiscal year, upon application of the Governor of a State, the Administrator may make a grant, subject to such terms and conditions as the Administrator considers appropriate, under this section to the State for the purpose of assisting the State in the development and implementation of programs for the assessment and mitigation of radon.

(b) Application.-An application for a grant under this section in any fiscal year shall contain such information as the Administrator shall require, including each of the following:

(1) A description of the seriousness and extent of radon exposure in the State.

(2) An identification of the State agency which has the primary responsibility for radon programs and which will receive the grant, a description of the roles and responsibilities of the lead State agency and any other 
State agencies involved in radon programs, and description of the roles and responsibilities of any municipal, district, or areawide organization involved in radon programs.

(3) A description of the activities and programs related to radon which the State proposes in such year.

(4) A budget specifying Federal and State funding of each element of activity of the grant application.

(5) A 3-year plan which outlines long range program goals and objectives, tasks necessary to achieve them, and resource requirements for the entire 3-year period, including anticipated State funding levels and desired Federal funding levels. This clause shall apply only for the initial year in which a grant application is made.

(c) Eligible activities.-Activities eligible for grant assistance under this section are the following:

(1) Survey of radon levels, including special surveys of geographic areas or classes of buildings (such as, among others, public buildings, school buildings, high-risk residential construction types).

(2) Development of public information and educational materials concerning radon assessment, mitigation, and control programs.

(3) Implementation of programs to control radon in existing and new structures.

(4) Purchase by the State of radon measurement equipment or devices.

(5) Purchase and maintenance of analytical equipment connected to radon measurement and analysis, including costs of calibration of such equipment.

(6) Payment of costs of Environmental Protection Agency-approved training programs related to radon for permanent State or local employees.

(7) Payment of general overhead and program administration costs.

(8) Development of a data storage and management system for information concerning radon occurrence, levels, and programs.

(9) Payment of costs of demonstration of radon mitigation methods and technologies as approved by the Administrator, including State participation in the Environmental Protection Agency Home Evaluation Program.

(10) A toll-free radon hotline to provide information and technical assistance.

(d) Preference to certain states.-Beginning in fiscal year 1991, the Administrator shall give a preference for grant assistance under this section to States that have made reasonable efforts to ensure the adoption, by the authorities which regulate building construction within that State or political subdivisions within States, of the model construction standards and techniques for new buildings developed under section 304 [15 U.S.C. 2664]. (e) Priority activities and projects.-The Administrator shall support eligible activities contained in State applications with the full amount of available funds. In the event that State applications for funds exceed the total funds available in a fiscal year, the Administrator shall give priority to activities or projects proposed by States based on each of the following criteria:

(1) The seriousness and extent of the radon contamination problem to be addressed.

(2) The potential for the activity or project to bring about reduction in radon levels.

(3) The potential for development of innovative radon assessment techniques, mitigation measures as approved by the Administrator, or program management approaches which may be of use to other States.

(4) Any other uniform criteria that the Administrator deems necessary to promote the goals of the grant program and that the Administrator provides to States before the application process.

(f) Federal share.-The Federal share of the cost of radon program activities implemented with Federal assistance under this section in any fiscal year shall not exceed 75 percent of the costs incurred by the State in implementing such program in the first year of a grant to such State, 60 percent in the second year, and 50 percent in the third year. Federal assistance shall be made on the condition that the non-Federal share is provided from non-Federal funds.

(g) Assistance to local governments.-States may, at the Governor's discretion, use funds from grants under this section to assist local governments in implementation of activities eligible for assistance under paragraphs (2), (3), and (6) of subsection (c).

(h) Information.-

(1) The Administrator may request such information, data, and reports developed by the State as he considers necessary to make the determination of continuing eligibility under this section.

(2) Any State receiving funds under this section shall provide to the Administrator all radon-related information generated in its activities, including the results of radon surveys, mitigation demonstration projects, and risk communication studies. 
(3) Any State receiving funds under this section shall maintain, and make available to the public, a list of firms and individuals within the State that have received a passing rating under the Environmental Protection Agency proficiency rating program referred to in section 305(a)(2) [15 U.S.C. 2665(a)(2)]. The list shall also include the address and phone number of such firms and individuals, together with the proficiency rating received by each. The Administrator shall make such list available to the public at appropriate locations in each State which does not receive funds under this section unless the State assumes such responsibility.

(i) Limitations.-

(1) No grant may be made under this section in any fiscal year to a State which in the preceding fiscal year received a grant under this section unless the Administrator determines that such State satisfactorily implemented the activities funded by the grant in such preceding fiscal year.

(2) The costs of implementing paragraphs (4) and (9) of subsection (c) shall not in the aggregate exceed 50 percent of the amount of any grant awarded under this section to a State in a fiscal year. In implementing such paragraphs, a State should make every effort, consistent with the goals and successful operation of the State radon program, to give a preference to low-income persons.

(3) The costs of general overhead and program administration under subsection (c)(7) shall not exceed 25 percent of the amount of any grant awarded under this section to a State in a fiscal year.

(4) A State may use funds received under this section for financial assistance to persons only to the extent such assistance is related to demonstration projects or the purchase and analysis of radon measurement devices.

(j) Authorization.-

(1) There is authorized to be appropriated for grant assistance under this section an amount not to exceed $\$ 10,000,000$ for each of fiscal years 1989,1990 , and 1991.

(2) There is authorized to be appropriated for the purpose of administering the grant program under this section such sums as may be necessary for each of such fiscal years.

(3) Notwithstanding any other provision of this section, not more than 10 percent of the amount appropriated to carry out this section may be used to make grants to any one State.

(4) Funds not obligated to States in the fiscal year for which funds are appropriated under this section shall remain available for obligation during the next fiscal year.

(5) No amount appropriated under this subsection may be used to cover the costs of the proficiency rating program under section 305(a)(2) [15 U.S.C. 2665(a)(2)].

Radon in Schools

[15 U.S.C. 2667]

Sec. 307. (a) Study of radon in schools. -

(1) Authority.-The Administrator shall conduct a study for the purpose of determining the extent of radon contamination in the Nation's school buildings.

(2) List of high probability areas.- In carrying out such study, the Administrator shall identify and compile a list of areas within the United States which the Administrator determines have a high probability of including schools which have elevated levels of radon.

(3) Basis of list.-In compiling such list, the Administrator shall make such determinations on the basis of, among other things, each of the following:

(A) Geological data.

(B) Data on high radon levels in homes and other structures nearby any such school.

(C) Physical characteristics of the school buildings.

(4) Survey.-In conducting such study the Administrator shall design a survey which when completed allows Congress to characterize the extent of radon contamination in schools in each State. The survey shall include testing from a representative sample of schools in each high-risk area identified in paragraph (1) and shall include additional testing, to the extent resources are available for such testing. The survey also shall include any reliable testing data supplied by States, schools, or other parties.

(5) Assistance.-

(A) The Administrator shall make available to the appropriate agency of each State, as designated by the Governor of such State, a list of high risk areas within each State, including a delineation of such areas and any other data available to the Administrator for schools in that State. To assist such agencies, the Administrator also shall provide guidance and data detailing the risks associated with high radon 
levels, technical guidance and related information concerning testing for radon within schools, and methods of reducing radon levels.

(B) In addition to the assistance authorized by subparagraph (A), the Administrator is authorized to make available to the appropriate agency of each State, as designated by the Governor of such State, devices suitable for use by such agencies in conducting tests for radon within the schools under the jurisdiction of any such State agency. The Administrator is authorized to make available to such agencies the use of laboratories of the Environmental Protection Agency, or to recommend laboratories, to evaluate any such devices for the presence of radon levels.

(6) Diagnostic and remedial efforts.-The Administrator is authorized to select, from high-risk areas identified in paragraph (2), school buildings for purposes of enabling the Administrator to undertake diagnostic and remedial efforts to reduce the levels of radon in such school buildings. Such diagnostic and remedial efforts shall be carried out with a view to developing technology and expertise for the purpose of making such technology and expertise available to any local educational agency and the several States. (7) Status report.-On or before October 1, 1989, the Administrator shall submit to the Congress a status report with respect to action taken by the Administrator in conducting the study required by this section, including the results of the Administrator's diagnostic and remedial work. On or before October 1, 1989, the Administrator shall submit a final report setting forth the results of the study conducted pursuant to this section, including the results of the Administrator's diagnostic and remedial work, and the recommendations of the Administrator.

(b) Authorization.-For the purpose of carrying out the provisions of paragraph (6) of subsection (a), there are authorized to be appropriated such sums, not to exceed $\$ 500,000$, as may be necessary. For the purpose of carrying out the provisions of this section other than such paragraph (6), there are authorized to be appropriated such sums, not to exceed $\$ 1,000,000$, as may be necessary.

\section{Regional Radon Training Centers}

[15 U.S.C. 2668]

Sec. 308. (a) Funding program.-Upon application of colleges, universities, institutions of higher learning, or consortia of such institutions, the Administrator may make a grant or cooperative agreement, subject to such terms and conditions as the Administrator considers appropriate, under this section to the applicant for the purpose of establishing and operating a regional radon training center.

(b) Purpose of the centers.-The purpose of a regional radon training center is to develop information and provide training to Federal and State officials, professional and private firms, and the public regarding the health risks posed by radon and demonstrated methods of radon measurement and mitigation.

(c) Applications.-Any colleges, universities, institutions of higher learning or consortia of such institutions may submit an application for funding under this section. Such applications shall be submitted to the Administrator in such form and containing such information as the Administrator may require.

(d) Selection criteria.-The Administrator shall support at least 3 eligible applications with the full amount of available funds. The Administrator shall select recipients of funding under this section to ensure that funds are equitably allocated among regions of the United States, and on the basis of each of the following criteria:

(1) The extent to which the applicant's program will promote the purpose described in subsection (b).

(2) The demonstrated expertise of the applicant regarding radon measurement and mitigation methods and other radon-related issues.

(3) The demonstrated expertise of the applicant in radon training and in activities relating to information development and dissemination.

(4) The seriousness of the radon problem in the region.

(5) The geographical coverage of the proposed center.

(6) Any other uniform criteria that the Administrator deems necessary to promote the purpose described

in subsection (b) and that the Administrator provides to potential applicants prior to the application process. (e) Termination of funding.-No funding may be given under this section in any fiscal year to an applicant which in the preceding fiscal year received funding under this section unless the Administrator determines that the recipient satisfactorily implemented the activities that were funded in the preceding year.

(f) Authorization.-There is authorized to be appropriated to carry out the program under this section not to exceed $\$ 1,000,000$ for each of fiscal years 1989, 1990, and 1991 . 
Study of Radon in Federal Buildings

[15 U.S.C. 2669]

Sec. 309. (a) Study requirement.-The head of each Federal department or agency that owns a Federal building shall conduct a study for the purpose of determining the extent of radon contamination in such buildings. Such study shall include, in the case of a Federal building using a nonpublic water source (such as a well or other groundwater), radon contamination of the water.

(b) High-risk Federal buildings.-

(1) The Administrator shall identify and compile a list of areas within the United States which the Administrator, in consultation with Federal departments and agencies, determines have a high probability of including Federal buildings which have elevated levels of radon.

(2) In compiling such list, the Administrator shall make such determinations on the basis of, among other things, the following:

(A) Geological data.

(B) Data on high radon levels in homes and other structures near any such Federal building.

(C) Physical characteristics of the Federal buildings.

(c) Study designs.-Studies required under subsection (a) shall be based on design criteria specified by the Administrator. The head of each Federal department or agency conducting such a study shall submit, not later than July 1,1989 , a study design to the Administrator for approval. The study design shall follow the most recent Environmental Protection Agency guidance documents, including "A Citizen's Guide to Radon"; the "Interim Protocol for Screening and Follow Up: Radon and Radon Decay Products Measurements"; the "Interim Indoor Radon \& Radon Decay Product Measurement Protocol"; and any other recent guidance documents. The study design shall include testing data from a representative sample of Federal buildings in each high-risk area identified in subsection (b). The study design also shall include additional testing data to the extent resources are available, including any reliable data supplied by Federal agencies, States, or other parties.

(d) Information on risks and testing.-

(1) The Administrator shall provide to the departments or agencies conducting studies under subsection

(a) the following:

(A) Guidance and data detailing the risks associated with high radon levels.

(B) Technical guidance and related information concerning testing for radon within Federal buildings and water supplies.

(C) Technical guidance and related information concerning methods for reducing radon levels.

(2) In addition to the assistance required by paragraph (1), the Administrator is authorized to make available, on a cost reimbursable basis, to the departments or agencies conducting studies under subsection (a) devices suitable for use by such departments or agencies in conducting tests for radon within Federal buildings. For the purpose of assisting such departments or agencies in evaluating any such devices for the presence of radon levels, the Administrator is authorized to recommend laboratories or to make available to such departments or agencies, on a cost reimbursable basis, the use of laboratories of the Environmental Protection Agency.

(e) Study deadline.- Not later than June 1, 1990, the head of each Federal department or agency conducting a study under subsection (a) shall complete the study and provide the study to the Administrator.

(f) Report to congress.-Not later than October 1,1990, the Administrator shall submit a report to the Congress describing the results of the studies conducted pursuant to subsection (a).

Regulations

[15 U.S.C. 2670]

Sec. 310. The Administrator is authorized to issue such regulations as may be necessary to carry out the provisions of this title. [15 U.S.C. 2661 et seq.] 


\section{Additional authorizations}

[15 U.S.C. 2671]

Sec. 311. Amounts authorized to be appropriated in this title [15 U.S.C. 2661 et seq.] for purposes of carrying out the provisions of this title [15 U.S.C. 2661 et seq.] are in addition to amounts authorized to be appropriated under other provisions of law for radon-related activities.

\section{TITLE IV—LEAD EXPOSURE REDUCTION}

\section{Sec. 401. For the purposes of this title:}

\section{Definitions}

(1) Abatement.-The term "abatement" means any set of measures designed to permanently eliminate lead-based paint hazards in accordance with standards established by the Administrator under this title. Such term includes-

(A) the removal of lead-based paint and lead-contaminated dust, the permanent containment or encapsulation of lead-based paint, the replacement of lead-painted surfaces or fixtures, and the removal or covering of lead-contaminated soil; and

(B) all preparation, cleanup, disposal, and postabatement clearance testing activities associated with such measures.

(2) Accessible surface.-The term "accessible surface" means an interior or exterior surface painted with lead-based paint that is accessible for a young child to mouth or chew.

(3) Deteriorated paint.-The term "deteriorated paint" means any interior or exterior paint that is peeling, chipping, chalking or cracking or any paint located on an interior or exterior surface or fixture that is damaged or deteriorated.

(4) Evaluation.-The term "evaluation" means risk assessment, inspection, or risk assessment and inspection.

(5) Friction surface.-The term "friction surface" means an interior or exterior surface that is subject to abrasion or friction, including certain window, floor, and stair surfaces.

(6) Impact surface.-The term "impact surface" means an interior or exterior surface that is subject to damage by repeated impacts, for example, certain parts of door frames.

(7) Inspection.-The term "inspection" means (A) a surface-by-surface investigation to determine the presence of lead-based paint, as provided in section 302(c) of the Lead-Based Paint Poisoning Prevention Act, and (B) the provision of a report explaining the results of the investigation.

(8) Interim controls.-The term "interim controls" means a set of measures designed to reduce temporarily human exposure or likely exposure to lead-based paint hazards, including specialized cleaning, repairs, maintenance, painting, temporary containment, ongoing monitoring of lead- based paint hazards or potential hazards, and the establishment and operation of management and resident education programs. (9) Lead-based paint.-The term "lead-based paint" means paint or other surface coatings that contain lead in excess of 1.0 milligrams per centimeter squared or 0.5 percent by weight or $(A)$ in the case of paint or other surface coatings on target housing, such lower level as may be established by the Secretary of Housing and Urban Development, as defined in section 302(c) of the Lead-Based Paint Poisoning Prevention Act, or (B) in the case of any other paint or surface coatings, such other level as may be established by the Administrator.

(10) Lead-based paint hazard.-The term "lead-based paint hazard" means any condition that causes exposure to lead from lead-contaminated dust, lead-contaminated soil, lead-contaminated paint that is deteriorated or present in accessible surfaces, friction surfaces, or impact surfaces that would result in adverse human health effects as established by the Administrator under this title.

(11) Lead-contaminated dust.-The term "lead-contaminated dust" means surface dust in residential dwellings that contains an area or mass concentration of lead in excess of levels determined by the Administrator under this title to pose a threat of adverse health effects in pregnant women or young children. 
(12) Lead-contaminated soil.-The term "lead-contaminated soil" means bare soil on residential real property that contains lead at or in excess of the levels determined to be hazardous to human health by the Administrator under this title.

(13) Reduction.-The term "reduction" means measures designed to reduce or eliminate human exposure to lead-based paint hazards through methods including interim controls and abatement.

(14) Residential dwelling.-The term "residential dwelling" means-

(A) a single-family dwelling, including attached structures such as porches and stoops; or

(B) a single-family dwelling unit in a structure that contains more than 1 separate residential dwelling unit, and in which each such unit is used or occupied, or intended to be used or occupied, in whole or in part, as the home or residence of 1 or more persons.

(15) Residential real property.-The term "residential real property" means real property on which there is situated 1 or more residential dwellings used or occupied, or intended to be used or occupied, in whole or in part, as the home or residence of 1 or more persons.

(16) Risk assessment.-The term "risk assessment" means an on-site investigation to determine and report the existence, nature, severity and location of lead-based paint hazards in residential dwellings, including-

(A) information gathering regarding the age and history of the housing and occupancy by children under age 6;

(B) visual inspection;

(C) limited wipe sampling or other environmental sampling techniques;

(D) other activity as may be appropriate; and

(E) provision of a report explaining the results of the investigation.

(17) Target housing.-The term "target housing" means any housing constructed prior to 1978, except housing for the elderly or persons with disabilities (unless any child who is less than 6 years of age resides or is expected to reside in such housing for the elderly or persons with disabilities) or any 0-bedroom dwelling. In the case of jurisdictions which banned the sale or use of lead-based paint prior to 1978 , the Secretary of Housing and Urban Development, at the Secretary's discretion, may designate an earlier date.

Lead-Based Paint Activities Training And Certification

Sec. 402. (a) Regulations.-

(1) In general.-Not later than 18 months after the date of the enactment of this section, the Administrator shall, in consultation with the Secretary of Labor, the Secretary of Housing and Urban Development, and the Secretary of Health and Human Services (acting through the Director of the National Institute for Occupational Safety and Health), promulgate final regulations governing lead-based paint activities to ensure that individuals engaged in such activities are properly trained; that training programs are accredited; and that contractors engaged in such activities are certified. Such regulations shall contain standards for performing lead-based paint activities, taking into account reliability, effectiveness, and safety. Such regulations shall require that all risk assessment, inspection, and abatement activities performed in target housing shall be performed by certified contractors, as such term is defined in section 1004 of the Residential Lead-Based Paint Hazard Reduction Act of 1992. The provisions of this section shall supersede the provisions set forth under the heading "Lead Abatement Training and Certification" and under the heading "Training Grants" in title III of the Act entitled "An Act making appropriations for the Departments of Veterans Affairs and Housing and Urban Development, and for sundry independent agencies, commissions, corporations, and offices for the fiscal year ending September 30, 1992, and for other purposes', Public Law 102-139, and upon the enactment of this section the provisions set forth in such public law under such headings shall cease to have any force and effect.

(2) Accreditation of training programs.-Final regulations promulgated under paragraph (1) shall contain specific requirements for the accreditation of lead-based paint activities training programs for workers, supervisors, inspectors and planners, and other individuals involved in lead-based paint activities, including, but not limited to, each of the following:

(A) Minimum requirements for the accreditation of training providers.

(B) Minimum training curriculum requirements.

(C) Minimum training hour requirements.

(D) Minimum hands-on training requirements.

(E) Minimum trainee competency and proficiency requirements.

(F) Minimum requirements for training program quality control. 
(3) Accreditation and certification fees.-The Administrator (or the State in the case of an authorized State program) shall impose a fee on-

(A) persons operating training programs accredited under this title; and

(B) lead-based paint activities contractors certified in accordance with paragraph (1).

The fees shall be established at such level as is necessary to cover the costs of administering and enforcing the standards and regulations under this section which are applicable to such programs and contractors. The fee shall not be imposed on any State, local government, or nonprofit training program. The Administrator (or the State in the case of an authorized State program) may waive the fee for lead-based paint activities contractors under subparagraph (A) for the purpose of training their own employees.

(b) Lead-Based Paint Activities.-For purposes of this title, the term "lead-based paint activities" means-

(1) in the case of target housing, risk assessment, inspection, and abatement; and

(2) in the case of any public building constructed before 1978, commercial building, bridge, or other structure or superstructure, identification of lead-based paint and materials containing lead-based paint, deleading, removal of lead from bridges, and demolition.

For purposes of paragraph (2), the term "deleading" means activities conducted by a person who offers to eliminate lead-based paint or lead-based paint hazards or to plan such activities.

(c) Renovation and Remodeling.-

(1) Guidelines.--In order to reduce the risk of exposure to lead in connection with renovation and remodeling of target housing, public buildings constructed before 1978, and commercial buildings, the Administrator shall, within 18 months after the enactment of this section, promulgate guidelines for the conduct of such renovation and remodeling activities which may create a risk of exposure to dangerous levels of lead. The Administrator shall disseminate such guidelines to persons engaged in such renovation and remodeling through hardware and paint stores, employee organizations, trade groups, State and local agencies, and through other appropriate means.

(2) Study of certification.- The Administrator shall conduct a study of the extent to which persons engaged in various types of renovation and remodeling activities in target housing, public buildings constructed before 1978, and commercial buildings are exposed to lead in the conduct of such activities or disturb lead and create a lead-based paint hazard on a regular or occasional basis. The Administrator shall complete such study and publish the results thereof within 30 months after the enactment of this section.

(3) Certification determination.--Within 4 years after the enactment of this section, the Administrator shall revise the regulations under subsection (a) to apply the regulations to renovation or remodeling activities in target housing, public buildings constructed before 1978, and commercial buildings that create leadbased paint hazards. In determining which contractors are engaged in such activities, the Administrator shall utilize the results of the study under paragraph (2) and consult with the representatives of labor organizations, lead-based paint activities contractors, persons engaged in remodeling and renovation, experts in lead health effects, and others. If the Administrator determines that any category of contractors engaged in renovation or remodeling does not require certification, the Administrator shall publish an explanation of the basis for that determination.

\section{Identification of Dangerous Levels of Lead}

Sec. 403. Within 18 months after the enactment of this title, the Administrator shall promulgate regulations which shall identify, for purposes of this title and the Residential Lead-Based Paint Hazard Reduction Act of 1992, lead-based paint hazards, lead-contaminated dust, and lead-contaminated soil.

\section{Authorized State Programs}

Sec. 404 (a) Approval.-Any State which seeks to administer and enforce the standards, regulations, or other requirements established under section 402 or 406 , or both, may, after notice and opportunity for public hearing, develop and submit to the Administrator an application, in such form as the Administrator shall require, for authorization of such a State program. Any such State may also certify to the Administrator at the time of submitting such program that the State program meets the requirements of paragraphs (1) and (2) of subsection (b). Upon submission of such certification, the State program shall be deemed to be authorized under this section, and shall apply in such State in lieu of the corresponding Federal program under section 402 or 406, 
or both, as the case maybe, until such time as the Administrator disapproves the program or withdraws the authorization.

(b) Approval or Disapproval.-Within 180 days following submission of an application under subsection (a), the Administrator shall approve or disapprove the application. The Administrator may approve the application only if, after notice and after opportunity for public hearing, the Administrator finds that-

(1) the State program is at least as protective of human health and the environment as the Federal program under section 402 or 406 , or both, as the case may be, and

(2) such State program provides adequate enforcement.

Upon authorization of a State program under this section, it shall be unlawful for any person to violate or fail or refuse to comply with any requirement of such program.

(c) Withdrawal of Authorization.--If a State is not administering and enforcing a program authorized under this section in compliance with standards, regulations, and other requirements of this title, the Administrator shall so notify the State and, if corrective action is not completed within a reasonable time, not to exceed 180 days, the Administrator shall withdraw authorization of such program and establish a Federal program pursuant to this title.

(d) Model State Program.-Within 18 months after the enactment of this title, the Administrator shall promulgate a model State program which may be adopted by any State which seeks to administer and enforce a State program under this title. Such model program shall, to the extent practicable, encourage States to utilize existing State and local certification and accreditation programs and procedures. Such program shall encourage reciprocity among the States with respect to the certification under section 402 .

(e) Other State Requirements.-Nothing in this title shall be construed to prohibit any State or political subdivision thereof from imposing any requirements which are more stringent than those imposed by this title. (f) State and Local Certification.-The regulations under this title shall, to the extent appropriate, encourage States to seek program authorization and to use existing State and local certification and accreditation procedures, except that a State or local government shall not require more than 1 certification under this section for any lead-based paint activities contractor to carry out lead-based paint activities in the State or political subdivision thereof.

(g) Grants to States.-The Administrator is authorized to make grants to States to develop and carry out authorized State programs under this section. The grants shall be subject to such terms and conditions as the Administrator may establish to further the purposes of this title.

(h) Enforcement by Administrator.-If a State does not have a State program authorized under this section and in effect by the date which is 2 years after promulgation of the regulations under section 402 or 406 , the Administrator shall, by such date, establish a Federal program for section 402 or 406 (as the case may be) for such State and administer and enforce such program in such State.

\section{Lead Abatement and Measurement}

Sec. 405. (a) Program To Promote Lead Exposure Abatement.-The Administrator, in cooperation with other appropriate Federal departments and agencies, shall conduct a comprehensive program to promote safe, effective, and affordable monitoring, detection, and abatement of lead-based paint and other lead exposure hazards.

(b) Standards for Environmental Sampling Laboratories.-

(1) The Administrator shall establish protocols, criteria, and minimum performance standards for laboratory analysis of lead in paint films, soil, and dust. Within 2 years after the enactment of this title, the Administrator, in consultation with the Secretary of Health and Human Services, shall establish a program to certify laboratories as qualified to test substances for lead content unless the Administrator determines, by the date specified in this paragraph, that effective voluntary accreditation programs are in place and operating on a nationwide basis at the time of such determination. To be certified under such program, a laboratory shall, at a minimum, demonstrate an ability to test substances accurately for lead content.

(2) Not later than 24 months after the date of the enactment of this section, and annually thereafter, the Administrator shall publish and make available to the public a list of certified or accredited environmental sampling laboratories.

(3) If the Administrator determines under paragraph (1) that effective voluntary accreditation programs are in place for environmental sampling laboratories, the Administrator shall review the performance and effectiveness of such programs within 3 years after such determination. If, upon such review, the 
Administrator determines that the voluntary accreditation programs are not effective in assuring the quality and consistency of laboratory analyses, the Administrator shall, not more than 12 months thereafter, establish a certification program that meets the requirements of paragraph (1).

(c) Exposure Studies.-

(1) The Secretary of Health and Human Services (hereafter in this subsection referred to as the "Secretary"), acting through the Director of the Centers for Disease Control, (CDC), and the Director of the National Institute of Environmental Health Sciences, shall jointly conduct a study of the sources of lead exposure in children who have elevated blood lead levels (or other indicators of elevated lead body burden), as defined by the Director of the Centers for Disease Control.

(2) The Secretary, in consultation with the Director of the National Institute for Occupational Safety and Health, shall conduct a comprehensive study of means to reduce hazardous occupational lead abatement exposures. This study shall include, at a minimum, each of the following-

(A) Surveillance and intervention capability in the States to identify and prevent hazardous exposures to lead abatement workers.

(B) Demonstration of lead abatement control methods and devices and work practices to identify and prevent hazardous lead exposures in the workplace.

(C) Evaluation, in consultation with the National Institute of Environmental Health Sciences, of health effects of low and high levels of occupational lead exposures on reproductive, neurological, renal, and cardiovascular health.

(D) Identification of high risk occupational settings to which prevention activities and resources should be targeted.

(E) A study assessing the potential exposures and risks from lead to janitorial and custodial workers. (3) The studies described in paragraphs (1) and (2) shall, as appropriate, examine the relative contributions to elevated lead body burden from each of the following:

(A) Drinking water.

(B) Food.

(C) Lead-based paint and dust from lead-based paint.

(D) Exterior sources such as ambient air and lead in soil.

(E) Occupational exposures, and other exposures that the Secretary determines to be appropriate.

(4) Not later than 30 months after the date of the enactment of this section, the Secretary shall submit a report to the Congress concerning the studies described in paragraphs (1) and (2).

(d) Public Education.-

(1) The Administrator, in conjunction with the Secretary of Health and Human Services, acting through the Director of the Agency for Toxic Substances and Disease Registry, and in conjunction with the Secretary of Housing and Urban Development, shall sponsor public education and outreach activities to increase public awareness of -

(A) the scope and severity of lead poisoning from household sources;

(B) potential exposure to sources of lead in schools and childhood day care centers;

(C) the implications of exposures for men and women, particularly those of childbearing age;

(D) the need for careful, quality, abatement and management actions;

(E) the need for universal screening of children;

(F) other components of a lead poisoning prevention program;

(G) the health consequences of lead exposure resulting from lead- based paint hazards;

(H) risk assessment and inspection methods for lead-based paint hazards; and

(I) measures to reduce the risk of lead exposure from lead-based paint.

(2) The activities described in paragraph (1) shall be designed to provide educational services and information to-

(A) health professionals;

(B) the general public, with emphasis on parents of young children; (C) homeowners, landlords, and tenants;

(D) consumers of home improvement products;

(E) the residential real estate industry; and

(F) the home renovation industry. 
(3) In implementing the activities described in paragraph (1), the Administrator shall assure coordination with the President's Commission on Environmental Quality's education and awareness campaign on lead poisoning.

(4) The Administrator, in consultation with the Chairman of the Consumer Product Safety Commission, shall develop information to be distributed by retailers of home improvement products to provide consumers with practical information related to the hazards of renovation and remodeling where leadbased paint may be present.

(e) Technical Assistance.-

(1) Clearinghouse.- Not later than 6 months after the enactment of this subsection, the Administrator shall establish, in consultation with the Secretary of Housing and Urban Development and the Director of the Centers for Disease Control, a National Clearinghouse on Childhood Lead Poisoning (hereinafter in this section referred to as "Clearinghouse"). The Clearinghouse shall-

(A) collect, evaluate, and disseminate current information on the assessment and reduction of lead-based paint hazards, adverse health effects, sources of exposure, detection and risk assessment methods, environmental hazards abatement, and clean-up standards;

(B) maintain a rapid-alert system to inform certified lead-based paint activities contractors of significant developments in research related to lead-based paint hazards; and

(C) perform any other duty that the Administrator determines necessary to achieve the purposes of this Act.

(2) Hotline.-Not later than 6 months after the enactment of this subsection, the Administrator, in cooperation with other Federal agencies and with State and local governments, shall establish a single lead-based paint hazard hotline to provide the public with answers to questions about lead poisoning prevention and referrals to the Clearinghouse for technical information.

(f) Products for Lead-Based Paint Activities.--Not later than 30 months after the date of enactment of this section, the President shall, after notice and opportunity for comment, establish by rule appropriate criteria, testing protocols, and performance characteristics as are necessary to ensure, to the greatest extent possible and consistent with the purposes and policy of this title, that lead-based paint hazard evaluation and reduction products introduced into commerce after a period specified in the rule are effective for the intended use described by the manufacturer. The rule shall identify the types or classes of products that are subject to such rule. The President, in implementation of the rule, shall, to the maximum extent possible, utilize independent testing laboratories, as appropriate, and consult with such entities and others in developing the rules. The President may delegate the authorities under this subsection to the Environmental Protection Agency or the Secretary of Commerce or such other appropriate agency.

\section{Lead Hazard Information Pamphlet}

Sec. 406. (a) Lead Hazard Information Pamphlet.-Not later than 2 years after the enactment of this section, after notice and opportunity for comment, the Administrator of the Environmental Protection Agency, in consultation with the Secretary of Housing and Urban Development and with the Secretary of Health and Human Services, shall publish, and from time to time revise, a lead hazard information pamphlet to be used in connection with this title and section 1018 of the Residential Lead-Based Paint Hazard Reduction Act of 1992. The pamphlet shall-

(1) contain information regarding the health risks associated with exposure to lead;

(2) provide information on the presence of lead-based paint hazards in federally assisted, federally owned, and target housing;

(3) describe the risks of lead exposure for children under 6 years of age, pregnant women, women of childbearing age, persons involved in home renovation, and others residing in a dwelling with lead-based paint hazards;

(4) describe the risks of renovation in a dwelling with lead-based paint hazards;

(5) provide information on approved methods for evaluating and reducing lead-based paint hazards and their effectiveness in identifying, reducing, eliminating, or preventing exposure to lead-based paint hazards; (6) advise persons how to obtain a list of contractors certified pursuant to this title in lead-based paint hazard evaluation and reduction in the area in which the pamphlet is to be used;

(7) state that a risk assessment or inspection for lead-based paint is recommended prior to the purchase, lease, or renovation of target housing; 
(8) state that certain State and local laws impose additional requirements related to lead-based paint in housing and provide a listing of Federal, State, and local agencies in each State, including address and telephone number, that can provide information about applicable laws and available governmental and private assistance and financing; and

(9) provide such other information about environmental hazards associated with residential real property as the Administrator deems appropriate.

(b) Renovation of Target Housing.-Within 2 years after the enactment of this section, the Administrator shall promulgate regulations under this subsection to require each person who performs for compensation a renovation of target housing to provide a lead hazard information pamphlet to the owner and occupant of such housing prior to commencing the renovation.

\section{Regulations}

Sec. 407. The regulations of the Administrator under this title shall include such recordkeeping and reporting requirements as may be necessary to insure the effective implementation of this title. The regulations may be amended from time to time as necessary.

\section{Control of Lead-Based Paint Hazards at Federal Facilities}

Sec. 408. Each department, agency, and instrumentality of executive, legislative, and judicial branches of the Federal Government (1) having jurisdiction over any property or facility, or (2) engaged in any activity resulting, or which may result, in a lead-based paint hazard, and each officer, agent, or employee thereof, shall be subject to, and comply with, all Federal, State, interstate, and local requirements, both substantive and procedural (including any requirement for certification, licensing, recordkeeping, or reporting or any provisions for injunctive relief and such sanctions as may be imposed by a court to enforce such relief) respecting lead-based paint, lead-based paint activities, and lead-based paint hazards in the same manner, and to the same extent as any nongovernmental entity is subject to such requirements, including the payment of reasonable service charges. The Federal, State, interstate, and local substantive and procedural requirements referred to in this subsection include, but are not limited to, all administrative orders and all civil and administrative penalties and fines regardless of whether such penalties or fines are punitive or coercive in nature, or whether imposed for isolated, intermittent or continuing violations. The United States hereby expressly waives any immunity otherwise applicable to the United States with respect to any such substantive or procedural requirement (including, but not limited to, any injunctive relief, administrative order, or civil or administrative penalty or fine referred to in the preceding sentence, or reasonable service charge).The reasonable service charges referred to in this section include, but are not limited to, fees or charges assessed for certification and licensing, as well as any other nondiscriminatory charges that are assessed in connection with a Federal, State, interstate, or local lead-based paint, lead-based paint activities, or lead-based paint hazard activities program. No agent, employee, or officer of the United States shall be personally liable for any civil penalty under any Federal, State, interstate, or local law relating to lead-based paint, lead-based paint activities, or lead-based paint hazards with respect to any act or omission within the scope of his official duties.

\section{Prohibited Acts}

Sec. 409. It shall be unlawful for any person to fail or refuse to comply with a provision of this title or with any rule or order issued under this title.

\section{Relationship to Other Federal Law}

Sec. 410. Nothing in this title shall affect the authority of other appropriate Federal agencies to establish or enforce any requirements which are at least as stringent as those established pursuant to this title.

\section{General Provisions Relating to Administrative Proceedings}

Sec. 411. (a) Applicability.-This section applies to the promulgation or revision of any regulation issued under this title. 
(b) Rulemaking Docket.-Not later than the date of proposal of any action to which this section applies, the Administrator shall establish a rulemaking docket for such action (hereinafter in this subsection referred to as a "rule"). Whenever a rule applies only within a particular State, a second (identical) docket shall be established in the appropriate regional office of the Environmental Protection Agency.

(c) Inspection and Copying.-

(1) The rulemaking docket required under subsection (b) shall be open for inspection by the public at reasonable times specified in the notice of proposed rulemaking. Any person may copy documents contained in the docket. The Administrator shall provide copying facilities which may be used at the expense of the person seeking copies, but the Administrator may waive or reduce such expenses in such instances as the public interest requires. Any person may request copies by mail if the person pays the expenses, including personnel costs to do the copying.

(2)-

(A) Promptly upon receipt by the agency, all written comments and documentary information on the proposed rule received from any person for inclusion in the docket during the comment period shall be placed in the docket. The transcript of public hearings, if any, on the proposed rule shall also be included in the docket promptly upon receipt from the person who transcribed such hearings. All documents which become available after the proposed rule has been published and which the Administrator determines are of central relevance to the rulemaking shall be placed in the docket as soon as possible after their availability.

(B) The drafts of proposed rules submitted by the Administrator to the Office of Management and Budget for any interagency review process prior to proposal of any such rule, all documents accompanying such drafts, and all written comments thereon by other agencies and all written responses to such written comments by the Administrator shall be placed in the docket no later than the date of proposal of the rule. The drafts of the final rule submitted for such review process prior to promulgation and all such written comments thereon, all documents accompanying such drafts, and written responses thereto shall be placed in the docket no later than the date of promulgation.

(d) Explanation.-

(1) The promulgated rule shall be accompanied by an explanation of the reasons for any major changes in the promulgated rule from the proposed rule.

(2) The promulgated rule shall also be accompanied by a response to each of the significant comments, criticisms, and new data submitted in written or oral presentations during the comment period.

(3) The promulgated rule may not be based (in part or whole) on any information or data which has not been placed in the docket as of the date of such promulgation.

(e) Judicial Review.-The material referred to in subsection (c)(2)(B) shall not be included in the record for judicial review.

(f) Effective Date.-The requirements of this section shall take effect with respect to any rule the proposal of which occurs after 90 days after the date of the enactment of this section.

\section{Authorization of Appropriations}

Sec. 412. There are authorized to be appropriated to carry out the purposes of this title such sums as may be necessary. 


\section{BLANK PAGE}




\section{IMPLEMENTING REGULATIONS}




\section{SECTION 3. IMPLEMENTING REGULATIONS}

The EPA's final regulations implementing TSCA are codified in CFR Title 40, Chapter I, Subchapter R, Parts 702, 704, 707, 710, 712, 716, 717, 720, 721, 723, 747, $750,761,762,763,775,790,791,792$, and $796-799$.

Regulations important to DOE include 40 CFR 717, 761, and 792. Brief summaries of these regulations follow.

\section{CFR 717-Records and Reports of Allegations that Chemical Substances Cause Significant Adverse Reactions to Health or the Environment}

These regulations apply to manufacturers, processors, and distributors of chemical substances and mixtures. They require long-term maintenance of records on adverse reactions to health and environment alleged to have been caused by a substance or mixture. Inspection and submission of copies of these records may also be required.

\section{CFR 761-Polychlorinated Biphenyls (PCBs) Manufacturing, Processing, Distribution in Commerce, and Use Prohibitions}

These regulations are specific to the handling of, and disposal techniques for, PCBs. With some exceptions, EPA has banned the manufacture, processing, distribution in commerce, and use of PCBs. PCBs may be used in totally enclosed systems such as intact, nonleaking, electrical transformers and capacitors found in television sets, air conditioners, and microwave ovens. Non-totally enclosed PCB activities are authorized under $\S 6(\mathrm{e})(2)(\mathrm{B})$ of TSCA and are described in 40 CFR 761.30. Substances that are regulated by this rule include, but are not limited to, dielectric fluids, contaminated solvents, oils, waste oils, heat transfer fluids, hydraulic fluids, paints, sludges, slurries, dredge spoils, soils, materials contaminated as a result of spills, and other chemical substances or combination of substances, including impurities and byproducts and any byproduct, intermediate, or impurity manufactured at any point in a process [40 CFR 761.1(b)].

\section{CFR 792- Good Laboratory Practice Standards}

These regulations establish laboratory practice standards to be used for TSCA testing. DOE-funded tests for TSCA compliance should be performed at laboratories meeting these standards. EPA amended the 
regulations to ensure the quality and integrity of data generated from such studies.

\section{CFR Parts 796 - 798}

In a final rule issued September 27, 1985 (50 FR 39252), EPA introduced Parts 796, 797 , and 798 which consist of TSCA test guidelines. This rule codified the guidelines which may be used to establish test standards in future TSCA Section 4 test rules. The guidelines in Parts 796 (chemical fate), 797 (environmental effects), and 798 (health effects) should make chemical-specific rules under Part 799 (Identification of specific chemical substance and mixture testing requirements) more usable and understandable. Those individuals interested in formulated procedures for laboratory testing of an effect or characteristic deemed important for the evaluation of health and environmental hazards of a chemical may wish to investigate these parts further.

\section{Recent Final Rulemakings}

Table 3-1 summarizes selected final changes to the regulatory program that became effective since the last update of this reference book (May 1992). Federal Register citations are provided in the table for more detailed information. 


\section{TABLE 3-1. SUMMARY OF FINAL CHANGES TO TSCA REGULATORY PROGRAM}

\begin{tabular}{|c|c|c|c|}
\hline $\begin{array}{c}\text { SUBJECT } \\
\text { Affected CFR } \\
\text { Citations(s) }\end{array}$ & $\begin{array}{l}\text { STATUS }^{\mathbf{a}} \\
\text { DATE } \\
\text { (FR citation) }\end{array}$ & $\begin{array}{l}\text { DESCRIPTTVE } \\
\text { SUMMARY }\end{array}$ & EFFECTIVE DATE \\
\hline $\begin{array}{l}\text { PAIR and Health and } \\
\text { Safety Data Reporting - } \\
\text { Addition of Chemicals } \\
40 \text { CFR } 712 \\
40 \text { CFR } 716\end{array}$ & $\begin{array}{l}\text { Final rule } \\
\text { 58 FR } 13556 \\
03 / 12 / 93\end{array}$ & $\begin{array}{l}\text { EPA added one substances, white } \\
\text { phosphorus, and one category of } \\
\text { chemical substances, alkyl-, } \\
\text { chloro-, hydroxymethyl diaryl } \\
\text { ethers, to its Section 8(a) } \\
\text { Preliminary Assessment Infor- } \\
\text { mation Rule (PAIR) and its } \\
\text { Section 8(d) Health and Safety } \\
\text { Data Reporting Rule. }\end{array}$ & Effective 4/12/93. \\
\hline $\begin{array}{l}\text { PAIR and Health and } \\
\text { Safety Data Reporting - } \\
\text { Addition of Chemicals } \\
40 \text { CFR } 712 \\
40 \text { CFR } 716\end{array}$ & $\begin{array}{l}\text { Final rule } \\
58 \text { FR 528511 } \\
05 / 14 / 93 \\
\text { Technical } \\
\text { amendment } \\
58 \text { FR } 47647 \\
09 / 10 / 93\end{array}$ & $\begin{array}{l}\text { EPA added two categories of } \\
\text { substances, silohexanes and } \\
\text { chloroalkyl phosphates, to its } \\
\text { Section 8(a) Preliminary Assess- } \\
\text { ment Information Rule (PAIR) } \\
\text { and its Section 8(d) Health and } \\
\text { Safety Data Reporting Rule. EPA } \\
\text { made certain technical, editorial, } \\
\text { and reporting changes to the PAIR } \\
\text { and health and safety data report- } \\
\text { ing final rule issued 5/14/93. }\end{array}$ & $\begin{array}{l}\text { Final rule effective } \\
6 / 14 / 93 \text {. } \\
\text { Technical amendment } \\
\text { effective } 10 / 12 / 93 \text {. }\end{array}$ \\
\hline $\begin{array}{l}\text { PAIR and Health and } \\
\text { Safety Data Reporting - } \\
\text { Addition of One } \\
\text { Chemical and One } \\
\text { Category } \\
40 \text { CFR } 712 \\
40 \text { CFR } 716\end{array}$ & $\begin{array}{l}\text { Final rule } \\
58 \text { FR } 68317 \\
12 / 27 / 93\end{array}$ & $\begin{array}{l}\text { EPA added thiophenol and certain } \\
\text { members of the chemical category } \\
\text { cyanoacrylates to the PAIR and } \\
\text { Section } 8(d) \text { health and safety } \\
\text { data reporting rules. }\end{array}$ & Effective $1 / 26 / 94$ \\
\hline $\begin{array}{l}\text { PAIR and Health and } \\
\text { Safety Data Reporting - } \\
\text { Addition of } 24 \\
\text { Chemicals } \\
40 \text { CFR } 712 \\
40 \text { CFR } 716\end{array}$ & $\begin{array}{l}\text { Final rule } \\
\text { 58 FR } 68311 \\
12 / 27 / 93 \\
\text { Final rule } \\
\text { 59 FR 5956 } \\
02 / 09 / 94\end{array}$ & $\begin{array}{l}\text { EPA added } 24 \text { chemical } \\
\text { substances and two categories of } \\
\text { chemical substances to the PAIR } \\
\text { and Section } 8(d) \text { health and safety } \\
\text { data reporting rule. }\end{array}$ & Effective 1/26/94 \\
\hline
\end{tabular}

(a) NOI = Notice of Intent 


\section{TABLE 3-1. SUMMARY OF FINAL CHANGES TO TSCA REGULATORY PROGRAM (Continued)}

\begin{tabular}{|c|c|c|c|}
\hline $\begin{array}{c}\text { SUBJECT } \\
\text { Affected CFR } \\
\text { Citations(s) }\end{array}$ & $\begin{array}{l}\text { STATUS }^{\mathrm{a}} \\
\text { DATE } \\
\text { (FR citation) }\end{array}$ & $\begin{array}{l}\text { DESCRIPTIVE } \\
\text { SUMMARY }\end{array}$ & EFFECTIVE DATE \\
\hline $\begin{array}{l}\text { PAIR and Health and } \\
\text { Safety Data Reporting - } \\
\text { Addition of Chemicals } \\
40 \text { CFR } 712 \\
40 \text { CFR } 716\end{array}$ & $\begin{array}{l}\text { Final rule } \\
\text { 59 FR 5956 } \\
02 / 09 / 94\end{array}$ & $\begin{array}{l}\text { EPA issued a final rule adding } 34 \\
\text { chemical substances to the TSCA } \\
\text { section 8(a) Preliminary } \\
\text { Assessment Information Rule and } \\
24 \text { chemical substances to the } \\
\text { TSCA section } 8 \text { (d) Health and } \\
\text { Safety Data Reporting Rule. }\end{array}$ & Effective $3 / 11 / 94$ \\
\hline $\begin{array}{l}\text { PCBs - Use of Waste } \\
\text { Oil } \\
40 \text { CFR } 761\end{array}$ & $\begin{array}{l}\text { Final rule } \\
\text { 58 FR } 15435 \\
03 / 23 / 93 \\
\text { Correction } \\
\text { 58 FR } 32060 \\
06 / 08 / 93\end{array}$ & $\begin{array}{l}\text { EPA replaced the references in } 40 \\
\text { CFR } 761.20(\mathrm{e}) \text { to reflect recent } \\
\text { changes made under RCRA } \\
\text { regarding the use of waste oil } \\
\text { containing PCBs. }\end{array}$ & Effective 3/23/93. \\
\hline $\begin{array}{l}\text { TSCA Inventory - } \\
\text { Removal } \\
\text { of } 36 \text { Chemical } \\
\text { Substances }\end{array}$ & $\begin{array}{l}\text { NOI } \\
\text { 58 FR } 19251 \\
04 / 13 / 93 \\
\text { Notice } \\
\text { 58 FR } 52493 \\
10 / 08 / 93\end{array}$ & $\begin{array}{l}\text { EPA deleted } 36 \text { chemical } \\
\text { substances from the TSCA } \\
\text { Chemical Substances Inventory } \\
\text { because it felt they were } \\
\text { incorrectly reported and listed. }\end{array}$ & Effective 10/8/93. \\
\hline $\begin{array}{l}\text { Health and Safety Data } \\
\text { Reporting Period } \\
\text { Terminations } \\
40 \text { CFR } 716\end{array}$ & $\begin{array}{l}\text { Final rule } \\
58 \text { FR } 42675 \\
08 / 11 / 93\end{array}$ & $\begin{array}{l}\text { EPA terminated the reporting } \\
\text { periods for } 92 \text { chemical substances } \\
\text { by amending the sunset dates on } \\
\text { the list of substances, mixtures, } \\
\text { and categories in the TSCA } \\
\text { Section } 8 \text { (d) reporting rule. EPA } \\
\text { has determined that it no longer } \\
\text { needs continuing data reporting } \\
\text { on these substances. }\end{array}$ & Effective 11/9/93. \\
\hline $\begin{array}{l}\text { Petition to Amend the } \\
\text { Definition of } \\
\text { Incinerator }\end{array}$ & $\begin{array}{l}\text { Notice } \\
\text { 58 FR 51816 } \\
\text { 10/05/93 }\end{array}$ & $\begin{array}{l}\text { EPA denied a petition submitted } \\
\text { under Section } 21 \text { of TSCA to } \\
\text { amend the definition of } \\
\text { "incinerator" as it applies to PCB } \\
\text { disposal. }\end{array}$ & \\
\hline
\end{tabular}

(a) $\mathrm{NOI}=$ Notice of Intent 


\section{TABLE 3-1. SUMMARY OF FINAL CHANGES TO TSCA REGULATORY PROGRAM (Continued)}

\begin{tabular}{|c|c|c|c|}
\hline $\begin{array}{c}\text { SUBJECT } \\
\text { Affected CFR } \\
\text { Citations(s) }\end{array}$ & $\begin{array}{l}\text { STATUS }^{\mathbf{a}} \\
\text { DATE } \\
\text { (FR citation) }\end{array}$ & $\begin{array}{l}\text { DESCRIPTIVE } \\
\text { SUMMARY }\end{array}$ & EFFECTIVE DATE \\
\hline $\begin{array}{l}\text { Asbestos Model } \\
\text { Accreditation Plan } \\
40 \text { CFR } 763\end{array}$ & $\begin{array}{l}\text { Interim final } \\
\text { rule } \\
\text { 59 FR } 5236 \\
02 / 03 / 94\end{array}$ & $\begin{array}{l}\text { EPA issued an interim final rule to } \\
\text { make revisions to its asbestos } \\
\text { Model Accreditation Plan } \\
\text { including additional hours of } \\
\text { hands-on health and safety } \\
\text { training for abatement workers } \\
\text { and contractor/supervisors. }\end{array}$ & Effective 4/4/94. \\
\hline $\begin{array}{l}\text { PCBs - Commerce } \\
\text { Exemption } \\
40 \text { CFR } 761\end{array}$ & $\begin{array}{l}\text { NPRM } \\
\text { 57 FR } 7349 \\
\text { 03/02/92 } \\
\text { Final rule } \\
\text { 59 FR 16991 } \\
04 / 11 / 94\end{array}$ & $\begin{array}{l}\text { EPA granted three and denied two } \\
\text { petitions for exemption from the } \\
\text { prohibition against the } \\
\text { manufacture, processing, and } \\
\text { distribution in commerce of } \\
\text { PCBs. EPA also amended the } \\
\text { interim procedural rules to require } \\
\text { submission of a certified letter at } \\
\text { least six months prior to the } \\
\text { expiration date of an exemption } \\
\text { for which the petitioner wants the } \\
\text { exemption to continue. }\end{array}$ & Effective $5 / 25 / 94$ \\
\hline
\end{tabular}

(a) NOI = Notice of Intent 
40 CFR 717 


\section{PART 717-RECORDS AND REPORTS OF ALLEGATIONS THAT CHEMICAL SUBSTANCES CAUSE SIGNIFICANT ADVERSE REACTIONS TO HEALTH OR THE ENVIRONMENT}

\author{
Subpart A-General Provisions
}

Sec.

717.1 Scope and compliance.

717.3 Definitions.

717.5 Persons subject to this part.

717.7 Persons not subject to this part.

717.10 Allegations subject to this part.

717.12 Significant adverse reactions that must be recorded.

717.15 Recordkeeping requirements.

717.17 Inspection and reporting requirements.

717.19 Confidentiality. Authority: 15 U.S.C. 2607(c).

Source: 48 FR 38187, Aug. 22, 1983, unless otherwise noted.

\section{Subpart A-General Provisions}

\$717.1 Scope and compliance.

Section 8 (c) of the Toxic Substances Control Act (TSCA) requires manufacturers, processors, and distributors of chemical substances and mixtures:

(a) To keep "records of significant adverse reactions to health or the environment, as determined by the Administrator by rule, alleged to have been caused by the substance or mixture."

(b) To "permit inspection and submit copies of such records", upon request of any designated representative of the Administrator. This rule implements section 8(c) of TSCA. It describes the records to be kept and prescribes the conditions under which certain firms must submit or make the records available to a duly designated representative of the Administrator.

\section{\$717.3 Definitions.}

The definitions set forth in section 3 of TSCA and the following definitions apply to this part:

(a) "Allegation" means a statement, made without formal proof or regard for evidence, that a chemical substance or mixture has caused a significant adverse reaction to health or the environment. (b) "Firm" or "company" means any person, that is subject to this part, as defined in $\$ 717.5$.

(c)(1) "Known human effects" means a commonly recognized human health effect of a particular substance or mixture as described either in:

(i) Scientific articles or publications abstracted in standard reference sources.

(ii) The firm's product labeling or material safety data sheets (MSDS).

(2) However, an effect is not a "known human effect" if it:

(i) Was a significantly more severe toxic effect than previously described.

(ii) Was a manifestation of a toxic effect after a significantly shorter exposure period or lower exposure level than described.

(iii) Was a manifestation of a toxic effect by an exposure route different from that described.

(d) "Manufacture" or "process" means to manufacture or process for commercial purposes.

(e)(1) "Manufacture for commercial purposes" means to import, produce, or manufacture with the purpose of obtaining an immediate or eventual commercial advantage for the manufacturer, and includes, among other things, such "manufacture" of any amount of a chemical substance or mixture:

(i) For distribution in commerce, including for test marketing.

(ii) For use by the manufacturer, including use for product research and development, or as an intermediate.

(2) "Manufacture for commercial purposes" also applies to substances that are produced coincidentally during the manufacture, processing, use, or disposal of another substance or mixture, including both byproducts that are separated from that other substances or mixture and impurities that remain in that substance or mixture. Such byproducts and impurities may, or may not, in themselves have commercial value. They are nonetheless produced for the purpose of obtaining a commercial advantage since they are part of the manufacture of a chemical product for a commercial purpose.

(f) "Person" includes any individual, firm, company, corporation, joint venture, partnership, sole proprietorship, association, or any other business entity, any State or political subdivision thereof, and any department, agency, or instrumentally of the Federal Government. 
(g) "Process for commercial purposes" means the preparation of a chemical substance or mixture, after its manufacture, for distribution in commerce with the purpose of obtaining an immediate or eventual commercial advantage for the processor. Processing of any amount of a chemical substance or mixture is included. If a chemical substance or mixture containing impurities is processed for commercial purposes, then those impurities are also processed for commercial purposes.

(h) "Retailer" means a person who distributes in commerce a chemical substance, mixture, or article to ultimate purchasers who are not commercial entities.

(i) "Significant adverse reactions" are reactions that may indicate a substantial impairment of normal activities, or long-lasting or irreversible damage to health or the environment.

(j) "Site" means a contiguous property unit. Property divided only by a public right-of-way is considered one site. There may be multiple manufacturing, processing, or distribution activities occurring within a single site.

(k) "Substance" means a chemical substance or mixture unless otherwise indicated.

\section{\$717.5 Persons subject to this part.}

(a) Manufacturers.

(1) All manufacturers of chemical substances are subject to this part except as provided in $\$ 717.7$ (a). If manufacture of a chemical substance occurs at any site owned or controlled by a firm then that firm is subject to this part.

(2) A manufacturer must collect:

(i) Any allegation identifying a chemical substance it manufactures and any allegation identifying the operations in the manufacture of any chemical substance it manufactures.

(ii) Any allegation identifying any of its own processing or distribution in commerce activities with respect to any chemical substance it manufactures.

(iii) Any allegation identifying emissions, effluents, or other discharges from activities described in this paragraph.

(iv) Any allegation identifying a substance produced coincidentally during processing, use, storage or disposal of a chemical substance it manufactures.

(3) For the purpose of this part, owned or controlled means ownership of 50 percent or more of a firm's voting stock or other equity rights, or the power to control the management and policies of that firm.

(b) Processors.

(1) A person who processes chemical substances, who is not also a manufacturer of those chemical substances, is subject to this Part if (i) the person processes chemical substances to produce mixtures, or (ii) the person repackages chemical substances or mixtures.

(2) As a processor subject to this part such person must collect:

(i) Any allegation identifying any mixture it produces and distributes in commerce and any allegation identifying any chemical substance or mixture it repackages and distributes in commerce.

(ii) Any allegation identifying any of its own further processing or distribution in commerce activities of the products described in paragraph (b)(2)(i) of this section.

(iii) Any allegation identifying emissions, effluents, or other discharges from activities described in this paragraph.

(iv) Any allegation identifying a substance produced coincidentally during the processing, use, storage or disposal of the products described in paragraph (b)(2)(i) of this section.

(c) SIC code. SIC codes applicable to this part are published in Standard Industrial Classification Manual-1972 and the 1977 Supplement. This manual and supplement may be obtained from the U.S. Government Printing Office, Washington, D.C. 20402-stock number 4101-0006 and stock number 003-005-0170-0 respectively. Where there is a conflict between the SIC code use of a term and the definition of that term in this part, the definition in this part applies.

[48 FR 38187, Aug 22, 1983, as amended at 50 FR 46769, Nov. 13, 1985]

\section{$\$ 717.7$ Persons not subject to this part.}

(a) Manufacturers.

(1) Persons or site activities are exempt from this part if the means by which they manufacture a chemical substance solely involves mining or other solely extractive functions, e.g., those companies or sites within a company whose sole function is to mine mineral ores, extract petroleum or natural gas, quarry non-metallic minerals (including extraction of salts from seawater or brines), mine or otherwise extract coal, or separate gases from the atmosphere. This 
exemption may include, but is not necessarily limited to, firms engaged in activities as described in SIC Division B-Mining and SIC Code 2813-Industrial Gases.

(2) A person is not subject to this part if the chemical substances that person causes to be produced are limited to:

(i) Chemical substances that result from chemical reactions that occur incidental to exposure of another chemical substance, mixture, or article to environmental factors such as air, moisture, microbial organisms, or sunlight.

(ii) Chemical substances that result from chemical reactions that occur incidental to storage or disposal of other chemical substances, mixtures, or articles.

(iii) Chemical substances that result from chemical reactions that occur upon end use of other chemical substances, mixtures, or articles such as adhesives, paints, miscellaneous cleaners or other housekeeping products, fuel additives, water softening and treatment agents, photographic films, batteries, matches, or safety flares, and that are not themselves manufactured or imported for distribution in commerce for use as chemical intermediates.

(iv) Chemical substances that result from chemical reactions that occur upon use of curable plastic or rubber molding compounds, inks, drying oils, metal finishing compounds, adhesives, or paints, or other chemical substance formed during the manufacture of an article destined for the marketplace without further chemical change of the chemical substance.

(v) Chemical substances that result from chemical reactions that occur when (A) a stabilizer, colorant, odorant, antioxidant, filler, solvent, carrier, surfactant, plasticizer, corrosion inhibitor, antifoamer or defoamer, dispersant, precipitation-inhibitor, binder, emulsifier, deemulsifier, dewatering agent, agglomerating agent, adhesion promoter, flow modifier, pH adjuster, sequestrant, coagulant, flocculent, fire retardant, lubricant, chelating agent, or quality control reagent functions as intended, or (B) a chemical substance, which is intended solely to impart a specific physicochemical characteristic, functions as intended.

(b) [Reserved]

(c) Sole distributors. A person solely engaged in the distribution of chemical substances is exempt from this part, unless such person is also a manufacturer or processor subject to this part. For example, a "distributor" who repackages chemical substances or mixtures is considered to be a processor and, thus, is not a sole distributor. Sole distributors may include, but are not limited to, those firms that distribute chemical substances as described in the wholesale trade SIC codes 5161-Chemicals and Allied Products, 5171-Petroleum Bulk Stations and Terminals, and 5172-Petroleum and Petroleum Products Wholesalers, Except Bulk Stations and Terminals.

(d) Retailers. A person who is a retailer is exempt from this part unless such person is also a manufacturer or a processor subject to this part.

[48 FR 38187, Aug 22, 1983, as amended at 50 FR 46770, Nov. 13, 1985]

\section{\$717.10 Allegations subject to this part.}

(a) Allegations subject to this part are those allegations received on or after November 21,1983 by persons subject to this part.

(b) Allegations subject to this part are those that:

(1) Are submitted either in writing and are signed by the alleger, or are submitted orally. In the case of an oral allegation, the firm must transcribe the allegation into written form, or it must inform the alleger that such allegation may be subject to this part and request that the alleger submit such allegation to the firm in writing and signed.

(2) Implicate a substance that caused the stated significant adverse reaction by one of the following:

(i) Naming the specific substance.

(ii) Naming a mixture that contains a specific substance.

(iii) Naming an article that contains a specific substance.

(iv) Naming a company process or operation in which substances are involved.

(v) Identifying an effluent, emission, or other discharge from a site of manufacturing, processing or distribution of a substance.

(c) Allegations subject to this part may be made to a firm by any person, such as an employee of the firm, individual consumer, a neighbor of the firm's plant, another firm on behalf of its employees or an organization on behalf of its members.

(d) EPA intends that firms should, to the maximum practical extent, provide allegers with information regarding the ultimate disposition of their allegations. For example, 
firms could provide a brief notice to the alleger stating that a record was created under this part based upon their allegation, or that a record was not created and briefly explain the reasons why not.

\section{$\$ 717.12$ Significant adverse reactions that must be recorded.}

(a) Except as provided in paragraph (b) of this section, significant adverse reactions to human health that must be recorded include but are not limited to:

(1) Long-lasting or irreversible damage, such as cancer or birth defects.

(2) Partial or complete impairment of bodily functions, such as reproductive disorders, neurological disorders or blood disorders.

(3) An impairment of normal activities experienced by all or most of the persons exposed at one time.

(4) An impairment of normal activities which is experienced each time an individual is exposed.

(b) Firms are not required to record significant adverse reactions that are known human effects as defined in $\$ 717.3$ (c).

(c) Except as provided in paragraph (d) of this section, significant adverse reactions to the environment that must be recorded, even if restricted to the environs of a plant or disposal site, include but are not limited to:

(1) Gradual or sudden changes in the composition of animal life or plant life, including fungal or microbial organisms, in an area.

(2) Abnormal number of deaths of organisms (e.g., fish kills).

(3) Reduction of the reproductive success or the vigor of a species.

(4) Reduction in agricultural productivity, whether crops or livesrock.

(5) Alterations in the behavior or distribution of a species.

(6) Long lasting or irreversible contamination of components of the physical environment, especially in the case of ground water, and surface water and soil resources that have limited self-cleansing capability.

(d) Firms are not required to record a significant adverse reaction to the environment if the alleged cause of that significant adverse reaction can be directly attributable to an accidental spill or other accidental discharge, emission exceeding permitted limits, or other incident of environmental contamination that has been reported to the Federal Government under any applicable authority.

[48 FR 38187, Aug. 22, 1983, as amended at 49 FR 23183, June 5, 1984; 58 FR 34204; June 23, 1993]

\section{\$717.15 Recordkeeping requirements.}

(a) Establishment and location of records. A firm subject to this part shall establish and maintain records of significant adverse reactions alleged to have been caused by chemical substances or mixtures manufactured or processed by the firm. Such records shall be kept at the firm's headquarters or at any other appropriate location central to the firm's chemical operations.

(b) Content of records. The record shall consist of the following:

(1) The original allegation as received.

(2) An abstract of the allegation and other pertinent information as follows:

(i) The name and address of the plant site which received the allegation.

(ii) The date the allegation was received at that site.

(iii) The implicated substance, mixture, article, company process or operation, or site discharge.

(iv) A description of the alleger (e.g., "company employee," "individual consumer;" "plant neighbor"). If the allegation involves a health effect, the sex and year of birth of the individual should be recorded, if ascertainable.

(v) A description of the alleged health effect(s). The description must relate how the effect(s) became known and the route of exposure, if explained in the allegation.

(vi) A description of the nature of the alleged environmental effect(s), identifying the affected plant and/or animal species, or contaminated portion of the physical environment.

(3) The results of any self-initiated investigation with respect to an allegation. (EPA does not require persons subject to this part to investigate allegations received, and no provision of this part shall be construed to imply that EPA recommends, encourages or requires such investigation.)

(4) Copies of any further required records or reports relating to the allegation. For example, if an employee allegation results in a requirement for the firm to record the case on Occupational Safety and Health Form 101 or appropriate substitute (see 29 CFR Part 1904 for requirements under the 
Occupational Safety and Health Act of 1970), a copy of that OSHA record must be included in the allegation record.

(c) File structure. Records must be retrievable by the alleged cause of the significant adverse reaction, which cause may be one of the following:

(1) A specific chemical identity.

(2) A mixture.

(3) An article.

(4) A company process or operation.

(5) A site emission, effluent or other discharge.

(d) Retention period. Records of significant adverse reactions to the health of employees shall be retained for a period of 30 years from the date such reactions were first reported to or known by the person maintaining such records. This provision requires persons subject to this part to retain for 30 years an employee health related allegation, arising from any employment related exposure, whether or not such allegation was submitted by or on the behalf of that recordkeeper's own employee. Any other record of significant adverse reactions shall be maintained for a period of five years from the date the information contained in the record was first reported to or known by the person maintaining the record.

(e) Transfer of records.

(1) If a firm ceases to do business, the successor must receive and keep all the records that must be kept under this part.

(2) If a firm ceases to do business and there is no successor to receive and keep the records for the prescribed period, these records must be transmitted to EPA. See \$717.17(c) for the address to which such records must be sent.

[48 FR 38187, Aug. 22, 1983, as amended at 49 FR 23183, June 5, 1984; 58 FR 34204, June 23, 1993]

\section{$\$ 717.17$ Inspection and reporting requirements.}

(a) Inspection. Firms must make records of allegations available for inspection by any duly designated representative of the Administrator.

(b) Reporting. Each person who is required to keep records under this part must submit copies of those records to the Agency as required by the EPA Administrator or appropriate designee. EPA will notify those responsible for reporting by letter or will announce any such requirements for submitting copies of records by a notice in the Federal Register. Such letter or notice will be signed by the Administrator or appropriate designee, and will specify which records or portion of records must be submitted. The reporting period will be specified by the letter or notice but in no case will such reporting period be less than 45 days from the date of the letter or the effective date of the notice.

(c) How to report. When required to report, firms must submit copies of records (preferably by certified mail) to: Document Processing Center (TS-790) Rm. L-100, Office of Toxic Substances, Environmental Protection Agency, 401 M St., SW., Washington, DC 20460. ATTN: 8(c) Allegations.

[48 FR 38187, Aug. 22, 1983, as amended at 49 FR 23183, June 5, 1984; 52 FR 20084, May 29, 1987; 53 FR 12523, Apr. 15, 1988; 58 FR 34204, June 23, 1993]

\section{$\$ 717.19$ Confidentiality.}

(a) Any person submitting copies of records may assert a business confidentiality claim covering all or part of the submitted information. Any information covered by a claim will be disclosed by EPA only as provided in procedures set forth at Part 2 of this title.

(b) If no claim accompanies a document at the time it is submitted to EPA, the document will be placed in an open file available to the public without further notice to the respondent.

(c) To asset a claim of confidentiality for information contained in a submitted record, the respondent must submit two copies of the document.

(1) One copy must be complete. In that copy, the respondent must indicate what information, if any, is claimed as confidential by marking the specific information on each page with a label such as "confidential", "proprietary", or "trade secret" and briefly state the basis of the claim.

(2) If some information is claimed as confidential, the respondent must submit a second copy of the record. The second copy must be complete, except that all information claimed as confidential in the first copy must be deleted.

(3) The first copy will be for internal use by EPA. The second copy will be placed in an open file to be available to the public.

(4) Failure to furnish a second copy when information is claimed as confidential in the first copy will be considered a presumptive waiver of the claim of confidentiality. EPA will notify the respondent by certified mail that a finding of a presumptive waiver of the 
claim of confidentiality has been made. The respondent will be given 30 days from the date of receipt of notification to submit the required second copy. If the respondent fails to submit the second copy within the 30 days, EPA will place the first copy in the public file. 
40 CFR 761 


\section{PART 761-POLYCHLORINATED BIPHENYLS (PCBs) \\ MANUFACTURING, PROCESSING, DISTRIBUTION IN COMMERCE, AND USE PROHIBITIONS}

Subpart A-General

Sec.

761.1 Applicability.

761.3 Definitions.

761.19 References.

Subpart B-Manufacturing, Processing, Distribution in Commerce, and Use of PCBs and PCB Items

761.20 Prohibitions.

761.30 Authorizations.

\section{Subpart C-Marking of PCBs and PCB Items}

761.40 Marking requirements.

761.45 Marking formats.

\section{Subpart D-Storage and Disposal}

761.60 Disposal requirements.

761.65 Storage for disposal.

761.70 Incineration.

761.75 Chemical waste landfills.

761.79 Decontamination.

\section{Subpart E-Exemptions}

761.80 Manufacturing, processing, and distribution in commerce exemptions.

\section{Subpart F-[Reserved]}

\section{Subpart G-PCB Spill Cleanup Policy}

761.120 Scope.

761.123 Definitions.

761.125 Requirements for PCB spill cleanup.

761.130 Sampling requirements.

761.135 Effect of compliance with this policy and enforcement.

Subparts $H$ and I [Reserved]

Subpart J-General Records and Reports

761.180 Records and monitoring.
761.185 Certification program and retention of records by importers and persons generating PCBs in excluded manufacturing processes.

761.187 Reporting importers and by persons generating PCBs in excluded manufacturing processes.

761.193 Maintenance of monitoring records by persons who import, manufacture, process, distribute in commerce, or use chemicals containing inadvertently generated PCBs.

Subpart K-PCB Waste Disposal Records and Reports

761.202 EPA identification numbers.

761.205 Notification of PCB waste activity (EPA Form 7710-53).

761.207 The manifest-general requirements.

761.208 Use of the manifest.

761.209 Retention of manifest records.

761.210 Manifest discrepancies.

761.211 Unmanifested waste report.

761.215 Exception reporting.

761.218 Certificate of disposal. 2616.

Authority: 15 U.S.C. 2605, 2607, 2611, 2614, and

\section{Subpart A-General}

\section{\$761.1 Applicability.}

(a) This part establishes prohibitions of, and requirements for, the manufacture, processing, distribution in commerce, use, disposal, storage, and marking of PCBs and PCB Items.

(b) This part applies to all persons who manufacture, process, distribute in commerce, use, or dispose of PCBs or PCB Items. Substances that are regulated by this rule include, but are not limited to, dielectric fluids, contaminated solvents, oils, waste oils, heat transfer fluids, hydraulic fluids, paints, sludges, slurries, dredge spoils, soils, materials contaminated as a result of spills, and other chemical substances or combination of substances, including impurities and byproducts and any byproduct, intermediate or impurity manufactured at any point in a process. Most of the provisions of this part apply to PCBs only if PCBs are present in concentrations above a specified level. For example, Subpart D applies 
generally to materials at concentrations of 50 parts per million (ppm) and above. Also certain provisions of Subpart B apply to PCBs inadvertently generated in manufacturing processes at concentrations specified in the definition of "PCB" under $\$ 761.3$. No provision specifying a PCB concentration may be avoided as a result of any dilution, unless otherwise specifically provided.

(c) Definitions of the terms used in these regulations are in Subpart A. The basic requirements applicable to disposal and marking of PCBs and PCB Items are set forth in Subpart D-Disposal of PCBs and PCB Items and in Subpart C-Marking of PCBs and PCB Items. Prohibitions applicable to PCB activities are set forth in Subpart $\mathrm{B}-\mathrm{Manufacture}$, Processing, Distribution in Commerce, and Use of PCBs and PCB Items. Subpart B also includes authorizations from the prohibitions. Subparts C and D set forth the specific requirements for disposal and marking of PCBs and PCB Items.

(d) Section 15 of the Toxic Substances Control Act (TSCA) states that failure to comply with these regulations is unlawful. Section 16 imposes liability for civil penalties upon any person who violates these regulations, and the Administrator can establish appropriate remedies for any violations subject to any limitations included in section 16 of TSCA. Section 16 also subjects a person to criminal prosecution for a violation which is knowing or willful. In addition, section 17 authorizes Federal district courts to enjoin activities prohibited by these regulations, compel the taking of actions required by these regulations, and issue orders to seize PCBs and PCB Items manufactured, processed or distributed in violation of these regulations.

(e) These regulations do not preempt other more stringent Federal statutes and regulations.

(f) Unless and until superseded by any new more stringent regulations issued under EPA authorities, or any permits or any pretreatment requirements issued by EPA, a state or local government that affect release of PCBs to any particular medium:

(1) Persons who inadvertently manufacture or import PCBs generated as unintentional impurities in excluded manufacturing processes, as defined in $\$ 761.3$, are exempt from the requirements of Subpart B of this part, provided that such persons comply with Subpart J of this part, as applicable.

(2) Persons who process, distribute in commerce, or use products containing PCBs generated in excluded manufacturing processes defined in $\$ 761.3$ are exempt from the requirements of Subpart B provided that such persons comply with Subpart J of this part, as applicable.

(3) Persons who process, distribute in commerce, or use products containing recycled $\mathrm{PCBs}$ defined in \$761.3, are exempt from the requirements of Subpart B of this part, provided that such persons comply with Subpart J of this part, as applicable.

(4) Except as provided in $\$ 761.20$ (d) and (e), persons who process, distribute in commerce, or use products containing excluded PCB products as defined in $\$ 761.3$, are exempt from the requirements of Subpart $B$ of this part.

(Sec. 6, Pub. L. 94-469, 90 Stat. 2020 (15 U.S.C. 2605)

[44 FR 31542, May 31, 1979, as amended at 49 FR 28189 , July 10,$1984 ; 53$ FR 24220 , June 27,1988 ]

\section{\$761.3 Definitions.}

For the purpose of this part:

"Administrator" means the Administrator of the Environmental Protection Agency, or any employee of the Agency to whom the Administrator may either herein or by order delegate his authority to carry out his functions, or any person who shall by operation of law be authorized to carry out such functions.

"Agency" means the United States Environmental Protection Agency.

"Annual document log" means the detailed information maintained at the facility on the PCB waste handling at the facility.

"Annual report" means the written document submitted each year by each disposer and commercial storer of PCB waste to the appropriate EPA Regional Administrator. The annual report is a brief summary of the information included in the annual document log.

"Byproduct" means a chemical substance produced without separate commercial intent during the manufacturing or processing of another chemical substance(s) or mixture(s).

"Capacitor" means a device for accumulating and holding a charge of electricity and consisting of conducting surfaces separated by a dielectric. Types of capacitors are as follows: 
(1) "Small capacitor" means a capacitor which contains less than $1.36 \mathrm{~kg}$ ( $3 \mathrm{lbs}$.) of dielectric fluid. The following assumptions may be used if the actual weight of the dielectric fluid is unknown. A capacitor whose total volume is less than 1,639 cubic centimeters (100 cubic inches) may be considered to contain less than $1.36 \mathrm{kgs}$ ( 3 lbs.) of dielectric fluid and a capacitor whose total volume is more than 3,278 cubic centimeters ( 200 cubic inches) must be considered to contain more than $1.36 \mathrm{~kg}$ (3 lbs.) of dielectric fluid. A capacitor whose volume is between 1,639 and 3,278 cubic centimeters may be considered to contain less then $1.36 \mathrm{~kg}$ ( $3 \mathrm{lbs}$.) of dielectric fluid if the total weight of the capacitor is less than 4.08 kg (9 lbs.).

(2) "Large high voltage capacitor" means a capacitor which contains $1.36 \mathrm{~kg}$ ( $3 \mathrm{lbs}$.) or more of dielectric fluid and which operates at 2,000 volts (a.c. or d.c.) or above.

(3) "Large low voltage capacitor" means a capacitor which contains $1.36 \mathrm{~kg}$ (3 lbs.) or more of dielectric fluid and which operates below 2,000 volts (a.c. or d.c.).

"Certification" means a written statement regarding a specific fact or representation that contains the following language:

Under civil and criminal penalties of law for the making or submission of false or fraudulent statements or representations (18 U.S.C. 1001 and 15 U.S.C. 2615), I certify that the information contained in or accompanying this document is true, accurate, and complete. As to the identified section(s) of this document for which I cannot personally verify truth and accuracy, I certify as the company official having supervisory responsibility for the persons who, acting under my direct instructions, made the verification that this information is true, accurate, and complete.

"Chemical substance", (1) except as provided in paragraph (2) of this definition, means any organic or inorganic substance of a particular molecular identity, including: Any combination of such substances occurring in whole or part as a result of a chemical reaction or occurring in nature, and any element or uncombined radical.

(2) Such term does not include: Any mixture; any pesticide (as defined in the Federal Insecticide, Fungicide, and Rodenticide Act) when manufactured, processed, or distributed in commerce for use as a pesticide; tobacco or any tobacco product; any source material, special nuclear material, or byproduct material (as such terms are defined in the Atomic Energy Act of 1954 and regulations issued under such Act); any article the sale of which is subject to the tax imposed by section 4181 of the Internal Revenue Code of 1954 (determined without regard to any exemptions from such tax provided by section 4182 or section 4221 or any provisions of such Code); and any food, food additive, drug, cosmetic, or device (as such terms are defined in section 201 of the Federal Food, Drug, and Cosmetic Act) when manufactured, processed, or distributed in commerce for use as a food, food additive, drug, cosmetic, or device.

"Chemical waste landfill" means a landfill at which protection against risk of injury to health or the environment from migration of PCBs to land, water, or the atmosphere is provided from PCBs and PCB Items deposited therein by locating, engineering, and operating the landfill as specified in $\$ 761.75$.

"Commerce" means trade, traffic, transportation, or other commerce:

(1) Between a place in a State and any place outside of such State, or

(2) Which affects trade, traffic, transportation, or commerce described in paragraph (1) of this definition.

Commercial storer of PCB waste means the owner or operator of each facility which is subject to the PCB storage facility standards of $\$ 761.65$, and who engages in storage activities involving $\mathrm{PCB}$ waste generated by others, or PCB waste that was removed while servicing the equipment owned by others and brokered for disposal. The receipt of a fee or any form of compensation for storage services is not necessary to qualify as a commercial storer of PCB waste. It is sufficient under this definition that the facility stores PCB waste generated by others or the facility removed the PCB waste while servicing equipment owned by others. A generator who stores only the generator's own waste is subject to the storage requirements of $\$ 761.65$, but is not required to seek approval as a commercial storer. If a facility's storage of PCB waste at no time exceeds 500 liquid gallons of PCBs, the owner or operator is not required to seek approval as a commercial storer of PCB waste.

"Designated facility" means the off-site disposer or commercial storer of PCB waste 
designated on the manifest as the facility that will receive a manifested shipment of $\mathrm{PCB}$ waste.

"Disposal" means intentionally or accidentally to discard, throw away, or otherwise complete or terminate the useful life of PCBs and PCB Items. Disposal includes spills, leaks, and other uncontrolled discharges of PCBs as well as actions related to containing, transporting, destroying, degrading, decontaminating, or confining PCBs and PCB Items.

"Disposer of PCB waste," as the term is used in subparts $\mathrm{J}$ and $\mathrm{K}$ of this part, means any person who owns or operates a facility approved by EPA for the disposal of PCB waste which is regulated for disposal under the requirements of subpart $D$ of this part.

"Distribute in commerce" and "Distribution in Commerce" when used to describe an action taken with respect to a chemical substance, mixture, or article containing a substance or mixture means to sell, or the sale of, the substance, mixture, or article in commerce; to introduce or deliver for introduction into commerce, or the introduction or delivery for introduction into commerce of the substance, mixture, or article; or to hold or the holding of, the substance, mixture, or article after its introduction into commerce.

"Emergency Situation" for continuing use of a PCB Transformer exists when:

(1) Neither a non-PCB Transformer nor a PCB-Contaminated transformer is currently in storage for reuse or readily available (i.e., available within 24 hours) for installation.

(2) Immediate replacement is necessary to continue service to power users.

"EPA identification number" means the 12-digit number assigned to a facility by EPA upon notification of PCB waste activity under $\$ 761.205$.

"Excluded manufacturing process" means a manufacturing process in which quantities of PCBs, as determined in accordance with the definition of inadvertently generated PCBs, calculated as defined, and from which releases to products, air, and water meet the requirements of paragraphs (1) through (5) of this definition, or the importation of products containing PCBs as unintentional impurities, which products meet the requirements of paragraphs (1) and (2) of this definition.

(1) The concentration of inadvertently generated PCBs in products leaving any manufacturing site or imported into the
United States must have an annual average of less than $25 \mathrm{ppm}$, with a $50 \mathrm{ppm}$ maximum.

(2) The concentration of inadvertently generated PCBs in the components of detergent bars leaving the manufacturing site or imported into the United States must be less than $5 \mathrm{ppm}$.

(3) The release of inadvertently generated PCBs at the point at which emissions are vented to ambient air must be less than 10 ppm.

(4) The amount of inadvertently generated PCBs added to water discharged from a manufacturing site must be less than 100 micrograms per resolvable gas chromatographic peak per liter of water discharged.

(5) Disposal of any other process wastes above concentrations of $50 \mathrm{ppm}$ PCB must be in accordance with Subpart $D$ of this part.

"Excluded PCB products" means PCB materials which appear at concentrations less than $50 \mathrm{ppm}$, including but not limited to:

(1) Non-Aroclor inadvertently generated PCBs as a byproduct or impurity resulting from a chemical manufacturing process.

(2) Products contaminated with Aroclor or other PCB materials from historic PCB uses (investment casting waxes are one example).

(3) Recycled fluids and/or equipment contaminated during use involving the products described in paragraphs (1) and (2) of this definition (heat transfer and hydraulic fluids and equipment and other electrical equipment components and fluids are examples).

(4) Used oils, provided that in the cases of paragraphs (1) through (4) of this definition:

(i) The products or source of the products containing $50 \mathrm{ppm}$ concentration PCBs were legally manufactured, processed, distributed in commerce, or used before October 1, 1984.

(ii) The products or source of the products containing $50 \mathrm{ppm}$ concentrations PCBs were legally manufactured, processed, distributed in commerce, or used, i.e., pursuant to authority granted by EPA regulation, by exemption petition, by settlement agreement, or pursuant to other Agency-approved programs;

(iii) The resulting PCB concentration (i.e. below $50 \mathrm{ppm}$ ) is not a result of dilution, or leaks and spills of PCBs in concentrations over 50 ppm.

"Fluorescent light ballast" means a device that electrically controls fluorescent light 
fixtures and that includes a capacitor containing $0.1 \mathrm{~kg}$ or less of dielectric.

"Generator of PCB waste" means any person whose act or process produces PCBs that are regulated for disposal under subpart $\mathrm{D}$ of this part, or whose act first causes PCBs or PCB Items to become subject to the disposal requirements of subpart $D$ of this part, or who has physical control over the PCBs when a decision is made that the use of the PCBs has been terminated and therefore is subject to the disposal requirements of subpart $D$ of this part. Unless another provision of this part specifically requires a site-specific meaning, "generator of PCB waste" includes all of the sites of PCB waste generation owned or operated by the person who generates PCB waste.

"Impurity" means a chemical substance which is unintentionally present with another chemical substance.

"In or Near Commercial Buildings" means within the interior of, on the roof of, attached to the exterior wall of, in the parking area serving, or within 30 meters of a non-industrial non-substation building. Commercial buildings are typically accessible to both members of the general public and employees, and include: (1) Public assembly properties, (2) educational properties, (3) institutional properties, (4) residential properties, (5) stores, (6) office buildings, and (7) transportation centers (e.g., airport terminal buildings, subway stations, bus stations, or train stations).

"Incinerator" means an engineered device using controlled flame combustion to thermally degrade PCBs and PCB Items. Examples of devices used for incineration include rotary kilns, liquid injection incinerators, cement kilns, and high temperature boilers.

"Industrial building" means a building directly used in manufacturing or technically productive enterprises. Industrial buildings are not generally or typically accessible to other than workers. Industrial buildings include buildings used directly in the production of power, the manufacture of products, the mining of raw materials, and the storage of textiles, petroleum products, wood and paper products, chemicals, plastics, and metals.

"Laboratory" means a facility that analyzes samples for PCBs and is unaffiliated with any entity whose activities involve PCBs.
"Leak" or "leaking" means any instance in which a PCB Article, PCB Container, or PCB Equipment has any PCBs on any portion of its external surface.

"Manifest" means the shipping document EPA form 8700-22 and any continuation sheet attached to EPA form 8700-22, originated and signed by the generator of $\mathrm{PCB}$ waste in accordance with the instructions included with the form and subpart $\mathrm{K}$ of this part.

"Manned Control Center" means an electrical power distribution control room where the operating conditions of a PCB Transformer are continuously monitored during the normal hours of operation (of the facility), and, where the duty engineers, electricians, or other trained personnel have the capability to deenergize a PCB Transformer completely within 1 minute of the receipt of a signal indicating abnormal operating conditions such as an overtemperature condition or overpressure condition in a PCB Transformer.

"Manufacture" means to produce, manufacture, or import into the customs territory of the United States.

"Manufacturing process" means all of a series of unit operations operating at a site, resulting in the production of a product.

"Mark" means the descriptive name, instructions, cautions, or other information applied to PCBs and PCB Items, or other objects subject to these regulations.

"Marked" means the marking of PCB Items and PCB storage areas and transport vehicles by means of applying a legible mark by painting, fixation of an adhesive label, or by any other method that meets the requirements of these regulations.

"Market/Marketers" means the processing or distributing in commerce, or the person who processes or distributes in commerce, used oil fuels to burners or other marketers, and may include the generator of the fuel if it markets the fuel directly to the burner.

"Mineral Oil PCB Transformer" means any transformer originally designed to contain mineral oil as the dielectric fluid and which has been tested and found to contain 500 ppm or greater PCBs.

"Mixture" means any combination of two or more chemical substances if the combination does not occur in nature and is not, in whole or in part, the result of a chemical reaction; except that such term does include any combination which occurs, in 
whole or in part, as a result of a chemical reaction if none of the chemical substances comprising the combination is a new chemical substance and if the combination could have been manufactured for commercial purposes without a chemical reaction at the time the chemical substances comprising the combination were combined.

"Municipal solid wastes" means garbage, refuse, sludges, wastes, and other discarded materials resulting from residential and non-industrial operations and activities, such as household activities, office functions, and commercial housekeeping wastes.

"Non-PCB Transformer" means any transformer that contains less than $50 \mathrm{ppm}$ PCB; except that any transformer that has been converted from a PCB Transformer or a PCB-Contaminated transformer cannot be classified as a non-PCB Transformer until reclassification has occurred, in accordance with the requirements of $\$ 761.30(a)(2)(v)$.

"On site" means within the boundaries of a contiguous property unit.

"PCB" and "PCBs" means any chemical substance that is limited to the biphenyl molecule that has been chlorinated to varying degrees or any combination of substances which contains such substance. Refer to \$761.1(b) for applicable concentrations of PCBs. PCB and PCBs as contained in PCB items are defined in $\S 761.3$. For any purposes under this part, inadvertently generated non-Aroclor PCBs are defined as the total PCBs calculated following division of the quantity of monochlorinated biphenyls by 50 and dichlorinated biphenyls by 5 .

"PCB Article" means any manufactured article, other than a PCB Container, that contains PCBs and whose surface(s) has been in direct contact with PCBs. "PCB Article" includes capacitors, transformers, electric motors, pumps, pipes and any other manufactured item (1) which is formed to a specific shape or design during manufacture, (2) which has end use function(s) dependent in whole or in part upon its shape or design during end use, and (3) which has either no change of chemical composition during its end use or only those changes of composition which have no commercial purpose separate from that of the PCB Article.

"PCB Article Container" means any package, can, bottle, bag, barrel, drum, tank, or other device used to contain PCB Articles or PCB Equipment, and whose surface(s) has not been in direct contact with PCBs.
"PCB Container" means any package, can, bottle, bag, barrel, drum, tank, or other device that contains PCBs or PCB Articles and whose surface(s) has been in direct contact with PCBs.

"PCB Equipment" means any manufactured item, other than a PCB Container or a PCB Article Container, which contains a PCB Article or other PCB Equipment, and includes microwave ovens, electronic equipment, and fluorescent light ballasts and fixtures.

"PCB Item" is defined as any PCB Article, PCB Article Container, PCB Container, or PCB Equipment, that deliberately or unintentionally contains or has a part of it any PCB or PCBs.

"PCB Transformer" means any transformer that contains $500 \mathrm{ppm} \mathrm{PCB}$ or greater.

"PCB-Contaminated Electrical Equipment" means any electrical equipment, including but not limited to transformers (including those used in railway locomotives and self-propelled cars), capacitors, circuit breakers, reclosers, voltage regulators, switches (including sectionalizers and motor starters), electromagnets, and cable, that contain $50 \mathrm{ppm}$ or greater PCB, but less than 500 ppm PCB. Oil-filled electrical equipment other than circuit breakers, reclosers, and cable whose PCB concentration is unknown must be assumed to be PCB-Contaminated Electrical Equipment. (See Sec.761.30(a) and (h) for provisions permitting reclassification of electrical equipment containing $500 \mathrm{ppm}$ or greater PCBs to PCB-Contaminated Electrical Equipment).

"PCB waste(s)" means those PCBs and PCB Items that are subject to the disposal requirements of subpart $D$ of this part.

"Person" means any natural or judicial person including any individual, corporation, partnership, or association; any State or political subdivision thereof; any interstate body; and any department, agency, or instrumentality of the Federal Government.

"Posing an exposure risk to food or feed" means being in any location where human food or animal feed products could be exposed to PCBs released from a PCB Item. A PCB Item poses an exposure risk to food or feed if PCBs released in any way from the PCB Item have a potential pathway to human food or animal feed. EPA considers human food or animal feed to include items regulated by the U.S. Department of Agriculture or the Food and Drug Administration as human 
food or animal feed; this includes direct additives. Food or feed is excluded from this definition if it is used or stored in private homes.

"Process" means the preparation of a chemical substance or mixture, after its manufacture, for distribution in commerce:

(1) In the same form or physical state as, or in a different form or physical state from, that in which it was received by the person so preparing such substance or mixture, or

(2) As part of an article containing the chemical substance or mixture.

"Qualified incinerator" means one of the following:

(1) An incinerator approved under the provisions of $\$ 761.70$. Any level of PCB concentration can be destroyed in an incinerator approved under $\$ 761.70$.

(2) A high efficiency boiler which complies with the criteria of $\$ 761.60(a)(2)(\mathrm{iii})(\mathrm{A})$, and for which the operator has given written notice to the appropriate EPA Regional Administrator in accordance with the notification requirements for the burning of mineral oil dielectric fluid under $\$ 761.60(\mathrm{a})(2)(\mathrm{iii})(\mathrm{B})$.

(3) An incinerator approved under section 3005(c) of the Resource Conservation and Recovery Act (42 U.S.C. 6925(c)) (RCRA).

(4) Industrial furnaces and boilers which are identified in 40 CFR 260.10 and 40 CFR 279.61(a)(1)and (2) when operating at their normal operating temperatures (this prohibits feeding fluids, above the level of detection, during either startup or shutdown operations).

"Quantifiable Level/Level of Detection" means 2 micrograms per gram from any resolvable gas chromatographic peak, i.e. 2 ppm.

"Recycled PCBs" means those PCBs which appear in the processing of paper products or asphalt roofing materials from PCB-contaminated raw materials. Processes which recycle PCBs must meet the following requirements:

(1) There are no detectable concentrations of PCBs in asphalt roofing material products leaving the processing site.

(2) The concentration of PCBs in paper products leaving any manufacturing site processing paper products, or in paper products imported into the United States, must have an annual average of less than 25 $\mathrm{ppm}$ with a $50 \mathrm{ppm}$ maximum.
(3) The release of PCBs at the point at which emissions are vented to ambient air must be less than $10 \mathrm{ppm}$.

(4) The amount of Aroclor PCBs added to water discharged from an asphalt roofing processing site must at all times be less than 3 micrograms per liter $(\mu \mathrm{g} / \mathrm{L})$ for total Aroclors (roughly 3 parts per billion ( $3 \mathrm{ppb}$ )). Water discharges from the processing of paper products must at all times be less than 3 micrograms per liter $(\mu \mathrm{g} / \mathrm{L})$ for total Aroclors (roughly $3 \mathrm{ppb}$ ), or comply with the equivalent mass-based limitation.

(5) Disposal of any other process wastes at concentrations of $50 \mathrm{ppm}$ or greater must be in accordance with Subpart D of this part.

"Retrofill" means to remove PCB or PCB-contaminated dielectric fluid and to replace it with either $\mathrm{PCB}, \mathrm{PCB}$-contaminated, or non-PCB dielectric fluid.

"Rupture of a PCB Transformer" means a violent or non-violent break in the integrity of a PCB Transformer caused by an overtemperature and/or overpressure condition that results in the release of PCBs.

"Sale for purposes other than resale" means sale of PCBs for purposes of disposal and for purposes of use, except where use involves sale for distribution in commerce. PCB Equipment which is first leased for purposes of use any time before July 1, 1979, will be considered sold for purposes other than resale.

"Small quantities for research and development" means any quantity of PCBs (1) that is originally packaged in one or more hermetically sealed containers of a volume of no more than five (5.0) milliliters, and (2) that is used only for purposes of scientific experimentation or analysis, or chemical research on, or analysis of, PCBs, but not for research or analysis for the development of a PCB product.

"Storage for disposal" means temporary storage of PCBs that have been designated for disposal.

"Totally enclosed manner" means any manner that will ensure no exposure of human beings or the environment to any concentration of PCBs.

"Transfer facility" means any transportation-related facility including loading docks, parking areas, and other similar areas where shipments of PCB waste are held during the normal course of transportation. Transport vehicles are not transfer facilities under this definition, unless they are used for 
the storage of PCB waste, rather than for actual transport activities. Storage areas for PCB waste at transfer facilities are subject to the storage facility standards of $\$ 761.65$, but such storage areas are exempt from the approval requirements of $\$ 761.65(d)$ and the recordkeeping requirements of $\$ 761.180$, unless the same PCB waste is stored there for a period of more than 10 consecutive days between destinations.

"Transport vehicle" means a motor vehicle or rail car used for the transportation of cargo by any mode. Each cargo-carrying body (e.g., trailer, railroad freight car) is a separate transport vehicle.

"Transporter of PCB waste" means, for the purposes of subpart $\mathrm{K}$ of this part, any person engaged in the transportation of regulated PCB waste by air, rail, highway, or water for purposes other than consolidation by a generator.

"Waste Oil" means used products primarily derived from petroleum, which include, but are not limited to, fuel oils, motor oils, gear oils, cutting oils transmission fluids, hydraulic fluids, and dielectric fluids.

(Sec. 6, Pub. L. 94-469, 90 Stat. 2020 (15 U.S.C. 2605) [49 FR 25239, June 20, 1984, as amended at 49 FR 28189 , July 10,$1984 ; 49$ FR 29066 , July 18,$1984 ; 49$ FR 44638 , Nov. 8, 1984; 50 FR 29199 , July 17,$1985 ; 50$ FR 32176, Aug. 9, 1985; 53 FR 24220, June 27, 1988; 53 FR 27327 , July 19,$1988 ; 54$ FR 52745 , Dec. 21,$1989 ; 55$ FR 26205, June 27, 1990; 58 FR 32061, June 8, 1993]

\section{$\$ 761.19$ References.}

(a) [Reserved]

(b) Incorporations by reference. The following material is incorporated by reference, and is available for inspection at the Office of the Federal Register Information Center, Rm. 8301, 1100 L St. NW., Washington, DC 20408. These incorporations by reference were approved by the Director of the Office of the Federal Register. These materials are incorporated as they exist on the date of approval and a notice of any change in these materials will be published in the Federal Register. Copies of the incorporated material may be obtained from the TSCA Public Docket Office (TS-793), Rm. NE-G004, Office of Toxic Substances, Environmental Protection Agency, 401 M St., SW., Washington, DC 20460 , or from the American Society for Testing and Materials (ASTM), 1916 Race Street, Philadelphia, PA 19103.

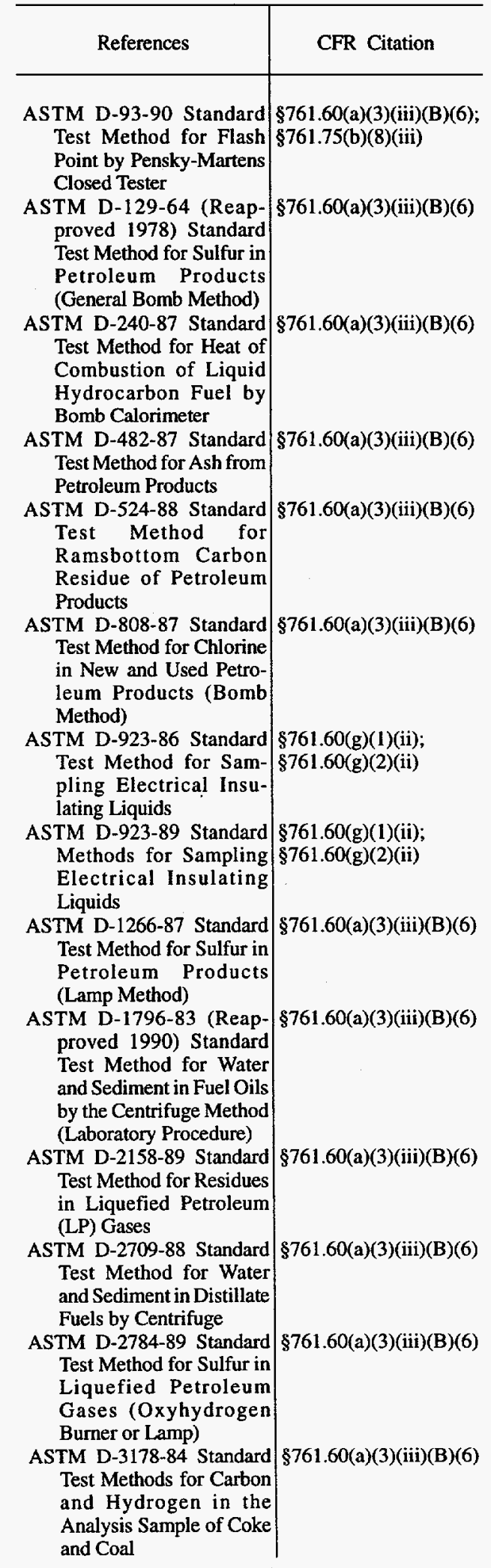




\begin{tabular}{c|c}
\hline References & CFR Citation \\
\hline ASTM D-3278-89 Standard & $\$ 761.75(\mathrm{~b})(8)(\mathrm{iii})$ \\
Test Methods for Flash & \\
Point of Liquid by & \\
Setaflash Closed-Cup & \\
Apparatus & \\
A STM E-258-67 (Reap- & $\$ 761.60(\mathrm{a})(3)(\mathrm{iii})(\mathrm{B})(6)$ \\
proved 1987) Standard & \\
Test Method for Total \\
Nitrogen Inorganic \\
Material by Modified \\
KJELDAHL Method
\end{tabular}

[47 FR 22098, May 21, 1982, as amended at 49 FR 29067, July 18, 1984; 49 FR 36648, Sept. 19, 1984; 53 FR 10391, Mar. 31, 1988; 53 FR 12524, Apr. 15, 1988; 53 FR 21641, June 9, 1988; 57 FR 13323, Apr. 16, 1992]

\section{Subpart B-Manufacturing, Processing, Distribution in Commerce, and Use of PCBs and PCB Items}

\section{\$761.20 Prohibitions.}

Except as authorized in $\$ 761.30$, the activities listed in paragraphs (a) and (d) of this section are prohibited pursuant to section $6(e)(2)$ of TSCA. The requirements set forth in paragraphs (b) and (c) of this section concerning export and import of PCBs for purposes of disposal and PCB Items for purposes of disposal are established pursuant to section 6(e)(1) of TSCA. Subject to any exemptions granted pursuant to section 6(e)(3)(B) of TSCA, the activities listed in paragraphs (b) and (c) of this section are prohibited pursuant to section (6)(e)(3)(A) of TSCA. In addition, the Administrator hereby finds, under the authority of section 12(a)(2) of TSCA, that the manufacture, processing, and distribution in commerce of PCBs at concentrations of $50 \mathrm{ppm}$ or greater and PCB Items with $\mathrm{PCB}$ concentrations of $50 \mathrm{ppm}$ or greater present an unreasonable risk of injury to health within the United States. This finding is based upon the well-documented human health and environmental hazard of PCB exposure, the high probability of human and environmental exposure to PCBs and PCB Items from manufacturing, processing, or distribution activities; the potential hazard of PCB exposure posed by the transportation of PCBs or PCB Items within the United States; and the evidence that contamination of the environment by PCBs is spread far beyond the areas where they are used. In addition, the Administrator hereby finds, for purposes of section $6(e)(2)(C)$ of TSCA, that any exposure of human beings or the environment to PCBs, as measured or detected by any scientifically acceptable analytical method, may be significant, depending on such factors as the quantity of PCBs involved in the exposure, the likelihood of exposure to humans and the environment, and the effect of exposure. For purposes of determining which PCB Items are totally enclosed, pursuant to section $6(\mathrm{e})(2)(\mathrm{C})$ of TSCA, since exposure to such Items may be significant, the Administrator further finds that a totally enclosed manner is a manner which results in no exposure to humans or the environment to PCBs. The following activities are considered totally enclosed: distribution in commerce of intact, nonleaking electrical equipment such as transformers (including transformers used in railway locomotives and self-propelled cars), capacitors, electromagnets, voltage regulators, switches (including sectionalizers and motor starters), circuit breakers, reclosers, and cable that contain PCBs at any concentration and processing and distribution in commerce of PCB Equipment containing an intact, nonleaking PCB Capacitor. See paragraph (c)(1) of this section for provisions allowing the distribution in commerce of PCBs and PCB Items.

(a) No persons may use any PCB, or any PCB Item regardless of concentration, in any manner other than in a totally enclosed manner within the United States unless authorized under \$761.30, except that:

(1) An authorization is not required to use those PCBs or PCB Items which consist of excluded PCB products as defined in $\$ 761.3$.

(2) An authorization is not required to use those PCBs or PCB Items resulting from an excluded manufacturing process or recycled PCBs as defined in $\$ 761.3$, provided all applicable conditions of \$761.1(f) are met.

(3) An authorization is not required to use those PCB Items which contain or whose surfaces have been in contact with excluded PCB products as defined in $\$ 761.3$.

(4) An authorization is not required to apply sewage sludges, contaminated with PCBs below $50 \mathrm{ppm}$, to land when regulated by authorities under the Clean Water Act and the Resource Conservation and Recovery Act.

(b) No person may manufacture PCBs for use within the United States or manufacture PCBs for export from the United States without an exemption except that: 
(1) No person may manufacture PCBs for use within the United States or manufacture PCBs for export from the United States without an exemption, except that an exemption is not required for PCBs manufactured in an excluded manufacturing process as defined in $\$ 761.3$, provided that all applicable conditions of \$761.1(f) are met.

(2) PCBs at concentrations less than 50 ppm may be imported or exported for purposes of disposal.

(c) No persons may process or distribute in commerce any PCB, or any PCB Item regardless of concentration, for use within the United States or for export from the United States without an exemption, except that an exemption is not required to process or distribute in commerce PCBs or PCB Items resulting from an excluded manufacturing process as defined in $\$ 761.3$, or to process or distribute in commerce recycled PCBs as defined in $\$ 761.3$, or to process or distribute in commerce excluded PCB products as defined in $\$ 761.3$, provided that all applicable conditions of $\$ 761.1(\mathrm{f})$ are met. In addition, the activities described in paragraphs (c) (1) through (5) of this section may also be conducted without an exemption, under the conditions specified therein.

(1) PCBs at concentrations of $50 \mathrm{ppm}$ or greater, or PCB Items with PCB concentrations of $50 \mathrm{ppm}$ or greater, sold before July 1,1979 for purposes other than resale may be distributed in commerce only in a totally enclosed manner after that date.

(2) PCBs at concentrations of $50 \mathrm{ppm}$ or greater, or PCB Items with PCB concentrations of $50 \mathrm{ppm}$ or greater may be processed and distributed in commerce in compliance with the requirements of this Part for purposes of disposal in accordance with the requirements of $\$ 761.60$.

(3) PCBs or PCB Items may be exported for disposal until May 1, 1980, if an export notice is submitted at least thirty (30) days before the first shipment in any calendar year leaves the customs territory of the United States. Export notices must be submitted to the TSCA Document Processing Center (TS-790), Rm. L-100, Office of Toxic Substances, Environmental Protection Agency, 401 M St., SW., Washington, DC 20460. The generator of the PCB waste material intended for disposal, or an agent acting on his behalf, must certify to the best of his knowledge and belief that the information is complete and accurate. Each notice should contain the following information:

(i) Name, company name, address, and telephone number of the owner of the PCB waste material to be exported and the name and address of any person or agent acting on his behalf;

(ii) Estimated quantity of wastes to be shipped during the calendar year and the estimated number of shipments to be made and the dates when such shipments are expected to leave the customs territory of the United States;

(iii) Description of the PCBs or PCB Items being exported;

(iv) Country(s) of destination for the shipments;

(v) Name and address of facility(s) receiving the shipment and person(s) responsible for receiving the shipment(s).

(vi) Method(s) of disposal and precautions taken to control release into the environment.

(vii) No less than 30 days after the end of each calendar quarter (March 31, June 30, September 30, and December 31) during which PCBs were exported for disposal, each person exporting the PCBs must submit a report to the TSCA Document Processing Center (TS-790), Rm. L-100, Office of Toxic Substances, Environmental Protection Agency, 401 M St., SW., Washington, DC 20460. The report shall list the quantity of PCB wastes in each shipment made during the quarter and include the date when each shipment left the customs territory of the United States and the information specified in paragraphs (c)(3)(i) and (iii) through (vi) of this section. If the quantity of wastes shipped during the calendar year exceeds by 25 percent or more the estimated quantities reported in paragraph (c)(3)(ii) of this section, a special export notice must be submitted to the TSCA Document Processing Center (TS-790) at the address given in paragraph (c)(3) of this section, at least 30 days before any additional shipments leave the customs territory of the United States and the notice shall include the information specified in paragraphs (c)(3)(i) through (vi) of this section.

(viii) Any person expecting to export PCB wastes for disposal in calendar year 1980 must submit an export notice at least thirty (30) days before the first shipment leaves the customs territory of the United States to the TSCA Document Processing Center (TS-790) at the address given in paragraph 
(c)(3) of this section, and the notice shall contain the information listed in paragraphs (c)(3)(i) through (vi) of this section.

(4) PCBs, at concentrations of less than 50 ppm, or PCB Items, with concentrations of less than $50 \mathrm{ppm}$, may be processed and distributed in commerce for purposes of disposal.

(5) Equipment, structures, or other materials that were contaminated with PCBs because of spills from, or proximity to, a PCB Item $50 \mathrm{ppm}$, and which are not otherwise authorized for use or distribution in commerce under this part, may be distributed in commerce, provided that these materials were decontaminated in accordance with applicable EPA PCB spill cleanup policies in effect at the time of the decontamination or, if not previously decontaminated, at the time of the distribution in commerce.

(d) The use of waste oil that contains any detectable concentration of PCB as a sealant, coating, or dust control agent is prohibited. Prohibited uses include, but are not limited to, road oiling, general dust control, use as a pesticide or herbicide carrier, and use as a rust preventative on pipes.

(e) In addition to any applicable requirements under 40 CFR Part 279 , Subparts $\mathrm{G}$ and $\mathrm{H}$, marketers and burners of used oil who market (process or distribute in commerce) for energy recovery, used oil containing any quantifiable level of PCBs are subject to the following requirements:

(1) Restrictions on marketing. Used oil containing any quantifiable level of PCBs (2 ppm) may be marketed only to:

(i) Qualified incinerators as defined in $\mathbf{4 0}$ CFR 761.3.

(ii) Marketers who market off-specification used oil for energy recovery only to other marketers who have notified EPA of their used oil management activities, and who have an EPA identification number is required by 40 CFR 279.73 . This would include persons who market off-specification used oil who are subject to the requirements at 40 CFR part 279 and the notification requirements of 40 CFR 279.73 .

(iii) Burners identified in $40 \mathrm{CFR}$ 279.61(a)(1) and (2). Only burners in the automotive industry may burn used oil generated from automotive sources in used oil-fired space heaters provided the provisions of 40 CFR 279.23 are met. The Regional Administrator may grant a variance for a boiler that does not meet the $40 \mathrm{CFR}$ 279.61(a)(1) and (2) criteria after considering the criteria listed in 40 CFR 260.32 (a) through (f). The applicant must address the relevant criteria contained in 40 CFR 260.32 (a) through ( $f$ ) in an application to the Regional Administrator.

(2) Testing of used oil fuel. Used oil to be burned for energy recovery is presumed to contain quantifiable levels (2 ppm) of PCB unless the marketer obtains analyses (testing) or other information that the used oil fuel does not contain quantifiable levels of PCBs.

(i) The person who first claims that a used oil fuel does not contain quantifiable level (2 ppm) PCB must obtain analyses or other information to support that claim.

(ii) Testing to determine the PCB concentration in used oil may be conducted on individual samples, or in accordance with the testing procedures described in $\$ 761.60(\mathrm{~g})(2)$. However, for purposes of this part, if any PCBs at a concentration of $50 \mathrm{ppm}$ or greater have been added to the container or equipment, then the total container contents must be considered as having a PCB concentration of $50 \mathrm{ppm}$ or greater for purposes of complying with the disposal requirements of this part.

(iii) Other information documenting that the used oil fuel does not contain quantifiable levels (2 ppm) of PCBs may consist of either personal, special knowledge of the source and composition of the used oil, or a certification from the person generating the used oil claiming that the oil contains no detectable PCBs.

(3) Restrictions on burning.

(i) Used oil containing any quantifiable levels of PCB may be burned for energy recovery only in the combustion facilities identified in paragraph (e)(1) of this section when such facilities are operating at normal operating temperatures (this prohibits feeding these fuels during either startup or shutdown operations). Owners and operators of such facilities are "burners" of used oil fuels.

(ii) Before a burner accepts from a marketer the first shipment of used oil fuel containing detectable PCBs (2 ppm), the burner must provide the marketer a one-time written and signed notice certifying that:

(A) The burner has complied with any notification requirements applicable to "qualified incinerators" ( $\$ 761.3)$ or to "burners" regulated under 40 CFR Part 279, Subpart G. 
(B) The burner will burn the used oil only in a combustion facility identified in paragraph (e)(1) of this section and identify the class of burner he qualifies.

(4) Recordkeeping requirements. The following recordkeeping requirements are in addition to the recordkeeping requirements for marketers found in 40 CFR 279.72(b), 279.74(a), (b) and (c), and for burners found in 40 CFR 279.65 and 279.66.

(i) Marketers. Marketers who first claim that the used oil fuel contains no detectable PCBs must include among the records required by 40 CFR 279.72 (b) and 279.74 (b) and (c) copies of the analysis or other information docu- menting his claim, and he must include among the records required by 40 CFR 279.74(a) and (c) and 279.75, a copy of each certification notice received or prepared relating to transactions involving PCB-containing used oil.

(ii) Burners. Burners must include among the records required by 40 CFR 279.65 and 279.66 , a copy of each certification notice required by paragraph (e)(3)(ii) of this section that he sends to a marketer.

(Sec. 6, Pub. L. 94-469, 90 Stat. 2020, (15 U.S.C. 2605)

[44 FR 31542, May 31, 1979. Redesignated at 47 FR 19527, May 6, 1982, and amended at 49 FR 25241, June 20, 1984; 49 FR 28190, July 10, 1984; 49 FR 44638, Nov. 8, 1984; 53 FR 12524, Apr. 15, 1988; 53 FR 24220, June 27, 1988; 58 FR 15435, Mar. 23, 1993; 58 FR 34205, June 23, 1993]

\section{$\$ 761.30$ Authorizations.}

The following non-totally enclosed PCB activities are authorized pursuant to section 6(e)(2)(B) of TSCA:

(a) Use in and servicing of transformers (other than railroad transformers). PCBs at any concentration may be used in transformers (other than in railroad locomotives and self-propelled railroad cars) and may be used for purposes of servicing including rebuilding these transformers for the remainder of their useful lives, subject to the following conditions:

(1) Use conditions.

(i) As of October 1, 1985, the use and storage for reuse of PCB Transformers that pose an exposure risk to food or feed is prohibited.

(ii) As of October 1, 1990, the use of network PCB Transformers with higher secondary voltages (secondary voltages equal to or greater than 480 volts, including $480 / 277$ volt systems) in or near commercial buildings is prohibited. Network PCB
Transformers with higher secondary voltages which are removed from service in accordance with this requirement must either be reclassified to PCB Contaminated or non PCB status, placed into storage for disposal, or disposed.

(iii) Except as otherwise provided, as of October 1, 1985, the installation of PCB Transformers, which have.been placed into storage for reuse or which have been removed from another location, in or near commercial buildings is prohibited.

(A) The installation of PCB Transformers on or after October 1, 1985, however, and their use thereafter, is permitted either in an emergency situation, as defined in $\$ 761.3$, or in situations where the transformer has been retrofilled and is being placed into service in order to qualify for reclassification under paragraph $(a)(2)(v)$ of this section.

(B) Installation of a PCB Transformer in an emergency situation is permitted when done in accordance with the following:

(1) Documentation to support the reason for the emergency installation of a PCB Transformer must be maintained at the owner's facility and completed within 30 days after installation of the PCB Transformer. The documentation must include, but is not limited to:

(i) The type of transformer, i.e., radial or lower or higher network, that requires replacement.

(ii) The type(s) of transformers, i.e., radial or lower or higher network, that must be used for replacement.

(iii) The date of transformer failure.

(iv) The date of subsequent replacement.

(v) The type of transformer, i.e., radial or lower or higher network, installed as a replacement.

(vi) A statement describing actions taken to locate a non-PCB or PCB-Contaminated transformer replacement.

(2) Such emergency installation is permitted until October 1, 1990, and the use of any PCB Transformer installed on such an emergency basis is permitted for 1 year from the date of installation or until October 1 , 1990 , whichever is earlier.

(3) PCB Transformers installed for emergency purposes may be subsequently reclassified; however, the transformer must be effectively reclassified to a non-PCB or PCB-Contaminated status within 1 year after installation or by October 1,1990 , whichever 
is earlier because the transformer was initially installed in an emergency situation.

(C) Installation of a retrofilled PCB Transformer for reclassification purposes is permitted when it is done in accordance with the following:

(1) Those who installed transformers for reclassification purposes must maintain on the owner's premises, completed within $\mathbf{3 0}$ days of installation, the following information:

(i) The date of installation.

(ii) The type of transformer, i.e., radial or lower or higher network, installed.

(iii) The PCB concentration, if known, at the time of installation.

(iv) The retrofill and reclassification schedule.

(2) For purposes of this paragraph, the installation of retrofilled PCB Transformers for purposes of reclassification under paragraph $(a)(2)(v)$ of this section is permitted until October 1, 1990.

(i) However, the use of a retrofilled PCB Transformer installed for reclassification purposes is limited to 18 months after installation or until October 1, 1990 , whichever is earlier.

(ii) Retrofilled mineral oil PCB Transformers may be installed for reclassification purposes indefinitely after October 1, 1990.

(iii) Once a retrofilled transformer has been installed for reclassification purposes, it must be tested 3 months after installation to ascertain the concentration of PCBs. If the PCB concentration is below $50 \mathrm{ppm}$, the transformer can be reclassified as a non-PCB Transformer. If the PCB concentration is between 50 and $500 \mathrm{ppm}$, the transformer can be reclassified as a PCB-Contaminated transformer. If the $\mathrm{PCB}$ concentration remains at $500 \mathrm{ppm}$ or greater, the entire process must either be repeated until the transformer has been reclassified to a non-PCB or PCB-Contaminated transformer in accordance with paragraph $(a)(2)(v)$ of this section or the transformer must be removed from service.

(D) Owners who installed PCB Transformers in emergency situations or for reclassification purposes between October 1 , 1985 and September 1, 1988 must notify the Regional Administrator in writing by October 3,1988 of such installation. The notification for emergency installation must include the information in paragraph $(\mathrm{a})(1)(\mathrm{iii})(\mathrm{B})(1)(\mathrm{i})$ through (vi) of this section. The notification for reclassification must include the information in paragraph (a)(1)(iii)(C)(1)(i) through (iv) of this section. All PCB Transformers installed in an emergency situation or. installed for reclassification purposes are subject to the requirements of this Part 761.

(iv) As of October 1, 1990, all higher secondary voltage radial PCB Transformers, in use in or near commercial buildings, and lower secondary voltage network PCB Transformers not located in sidewalk vaults in or near commercial buildings (network transformers with secondary voltages below 480 volts) that have not been removed from service as provided in paragraph (a)(1)(iv)(B) of this section, must be equipped with electrical protection to avoid transformer ruptures caused by high current faults. As of February 25, 1991, all lower secondary voltage radial PCB Transformers, in use in or near commercial buildings, must be equipped with electrical protection to avoid transformer ruptures caused by high current faults.

(A) Current-limiting fuses or other equivalent technology must be used to detect sustained high current faults and provide for the complete deenergization of the transformer (within several hundredths of a second in the case of higher secondary voltage radial PCB Transformers and within tenths of a second in the case of lower secondary voltage network PCB Transformers), before transformer rupture occurs. Lower secondary voltage radial $\mathrm{PCB}$ Transformers must be equipped with electrical protection as provided in paragraph (a)(1)(iv)(E) of this section. The installation, setting, and maintenance of current-limiting fuses or other equivalent technology to avoid PCB Transformer ruptures from sustained high current faults must be completed in accordance with good engineering practices.

(B) All lower secondary voltage network PCB Transformers not located in sidewalk vaults (network transformers with secondary voltages below 480 volts), in use in or near commercial buildings, which have not been protected as specified in paragraph (a)(1)(iv)(A) of this section by October 1 , 1990 , must be removed from service by October 1, 1993.

(C) As of October 1, 1990, owners of lower secondary voltage network PCB Transformers, in use in or near commercial buildings which have not been protected as 
specified in paragraph (a)(1)(iv)(A) of this section and which are not located in sidewalk vaults, must register in writing those transformers with the EPA Regional Administrator in the appropriate region. The information required to be provided in writing to the Regional Administrator includes:

(1) The specific location of the PCB Transformer(s).

(2) The address(es) of the building(s) and the physical location of the PCB Transformer(s) on the building site(s).

(3) The identification number(s) of the PCB Transformer(s).

(D) As of October 1, 1993, all lower secondary voltage network PCB Transformers located in sidewalk vaults (network transformers with secondary voltages below 480 volts) in use near commercial buildings must be removed from service.

(E) As of February 25, 1991, all lower secondary voltage radial PCB Transformers must be equipped with electrical protection, such as current-limiting fuses or other equivalent technology, to detect sustained high current faults and provide for the complete deenergization of the transformer or complete deenergization of the faulted phase of the transformer within several hundredths of a second. The installation, setting, and maintenance of current-limiting fuses or other equivalent technology to avoid $\mathrm{PCB}$ Transformer ruptures from sustained high current faults must be completed in accordance with good engineering practices.

(v) As of October 1, 1990, all radial PCB Transformers with higher secondary voltages (480 volts and above, including 480/277 volt systems) in use in or near commercial buildings must, in addition to the requirements of paragraph (a)(1)(iv)(A) of this section, be equipped with protection to avoid transformer ruptures caused by sustained low current faults.

(A) Pressure and temperature sensors (or other equivalent technology which has been demonstrated to be effective in early detection of sustained low current faults) must be used in these transformers to detect sustained low current faults.

(B) Disconnect equipment must be provided to insure complete deenergization of the transformer in the event of a sensed abnormal condition (e.g., an overpressure or overtemperature condition in the transformer), caused by a sustained low current fault. The disconnect equipment must be configured to operate automatically within 30 seconds to 1 minute of the receipt of a signal indicating an abnormal condition from a sustained low current fault, or can be configured to allow for manual deenergization from a manned on-site control center upon the receipt of an audio or visual signal indicating an abnormal condition caused by a sustained low current fault. Manual deenergization from a manned on-site control center must occur within 1 minute of the receipt of the audio or visual signal indicating an abnormal condition caused by a sustained low current fault. If automatic operation is selected and a circuit breaker is utilized for disconnection, it must also have the capability to be manually opened if necessary.

(C) The enhanced electrical protective system required for the detection of sustained low current faults and the complete and rapid deenergization of transformers must be properly installed, maintained, and set sensitive enough (in accordance with good engineering practices) to detect sustained low current faults and allow for rapid and total deenergization prior to $\mathrm{PCB}$ Transformer rupture (either violent or non violent rupture) and release of PCBs.

(vi) As of December 1, 1985, all PCB Transformers (including PCB Transformers in storage for reuse) must be registered with fire response personnel with primary jurisdiction (that is, the fire department or fire brigade which would normally be called upon for the initial response to a fire involving the equipment). Information required to be provided to fire response personnel includes:

(A) The location of the PCB Transformer(s) (the address(es) of the building(s) and the physical location of the PCB Transformer(s) on the building site(s) and for outdoor PCB Transformers, the location of the outdoor substation).

(B) The principal constituent of the dielectric fluid in the transformer(s) (e.g., PCBs, mineral oil, or silicone oil).

(C) The name and telephone number of the person to contact in the event of a fire involving the equipment.

(vii) As of December 1, 1985, PCB Transformers in use in or near commercial buildings must be registered with building owners. For PCB Transformers located in commercial buildings, PCB Transformer owners must register the transformers with the building owner of record. For PCB 
Transformers located near commercial buildings, PCB Transformer owners must register the transformers with all owners of buildings located within 30 meters of the PCB Transformer(s). Information required to be provided to building owners by PCB Transformer owners includes but is not limited to:

(A) The specific location of the PCB Transformer(s).

(B) The principal constituent of the dielectric fluid in the transformer(s) (e.g., PCBs, mineral oil, or silicone oil).

(C) The type of transformer installation (e.g., 208/120 volt network, 280/120 volt radial, 208 volt radial, 480 volt network, $480 / 277$ volt network, 480 volt radial, $480 / 277$ volt radial).

(viii) As of December 1, 1985, combustible materials, including, but not limited to paints, solvents, plastics, paper, and sawn wood must not be stored within a PCB Transformer enclosure (i.e., in a transformer vault or in a partitioned area housing a transformer); within 5 meters of a transformer enclosure, or, if unenclosed (unpartitioned), within 5 meters of a PCB Transformer.

(ix) A visual inspection of each PCB Transformer (as defined in the definition of "PCB Transformer" under \$761.3) in use or stored for reuse shall be performed at least once every 3 months. These inspections may take place any time during the 3-month periods: January-March, April-June, July-September, and October-December as long as there is a minimum of 30 days between inspections. The visual inspection must include investigation for any leak of dielectric fluid on or around the transformer. The extent of the visual inspections will depend on the physical constraints of each transformer installation and should not require an electrical shutdown of the transformer being inspected.

(x) If a PCB Transformer is found to have a leak which results in any quantity of PCBs running off or about to run off the external surface of the transformer, then the transformer must be repaired or replaced to eliminate the source of the leak. In all cases any leaking material must be cleaned up and properly disposed of according to disposal requirements of $\$ 761.60$. Cleanup of the released PCBs must be initiated as soon as possible, but in no case later than 48 hours of its discovery. Until appropriate action is completed, any active leak of PCBs must be contained to prevent exposure of humans or the environment and inspected daily to verify containment of the leak. Trenches, dikes, buckets, and pans are examples of proper containment measures.

(xi) If a PCB Transformer is involved in a fire-related incident, the owner of the transformer must immediately report the incident to the National Response Center (toll-free 1-800-424-8802; in Washington, DC 202-426-2675). A fire-related incident is defined as any incident involving a PCB Transformer which involves the generation of sufficient heat and/or pressure (by any source) to result in the violent or non-violent rupture of a PCB Transformer and the release of PCBs. Information must be provided regarding the type of $\mathrm{PCB}$ Transformer installation involved in the fire-related incident (e.g., high or low secondary voltage network transformer, high or low secondary voltage simple radial system, expanded radial system, primary selective system, primary loop system, or secondary selective system or other systems) and the readily ascertainable cause of the fire-related incident (e.g., high current fault in the primary or secondary or low current fault in secondary). The owner of the PCB Transformer must also take measures as soon as practically and safely possible to contain and control any potential releases of PCBs and incomplete combustion products into water. These measures include, but are not limited to:

(A) The blocking of all floor drains in the vicinity of the transformer.

(B) The containment of water runoff.

(C) The control and treatment (prior to release) of any water used in subsequent cleanup operations.

(xii) Records of inspection and maintenance history shall be maintained at least 3 years after disposing of the transformer and shall be made available for inspection, upon request by EPA. Such records shall contain the following information for each PCB Transformer:

(A) Its location.

(B) The date of each visual inspection and the date that leak was discovered, if different from the inspection date.

(C) The person performing the inspection.

(D) The location of any leak(s).

(E) An estimate of the amount of dielectric fluid released from any leak.

(F) The date of any cleanup, containment, repair, or replacement. 
(G) A description of any cleanup, containment, or repair performed.

(H) The results of any containment and daily inspection required for uncorrected active leaks.

(xiii) A reduced visual inspection frequency of at least once every 12 months applies to PCB Transformers that utilize either of the following risk reduction measures. These inspections may take place any time during the calendar year as long as there is a minimum of 180 days between inspections.

(A) A PCB Transformer which has impervious, undrained, secondary containment capacity of at least 100 percent of the total dielectric fluid volume of all transformers so contained or

(B) A PCB Transformer which has been tested and found to contain less than 60,000 ppm PCBs (after 3 months of in service use if the transformer has been serviced for purposes of reducing the $\mathrm{PCB}$ concentration).

(xiv) An increased visual inspection frequency of at least once every week applies to any PCB Transformer in use or stored for reuse which poses an exposure risk to food or feed. The user of a PCB Transformer posing an exposure risk to food is responsible for the inspection, recordkeeping, and maintenance requirements under this section until the user notifies the owner that the transformer may pose an exposure risk to food or feed. Following such notification, it is the owner's ultimate responsibility to determine whether the PCB Transformer poses an exposure risk to food or feed.

(xv) In the event a mineral oil transformer, assumed to contain less than $500 \mathrm{ppm}$ of PCBs as provided in $\$ 761.3$, is tested and found to be contaminated at $500 \mathrm{ppm}$ or greater PCBs, it will be subject to all the requirements of this Part 761. In addition, efforts must be initiated immediately to bring the transformer into compliance in accordance with the following schedule:

(A) Report fire-related incidents, effective immediately after discovery.

(B) Mark the PCB transformer within 7 days after discovery.

(C) Mark the vault door, machinery room door, fence, hallway or other means of access to the PCB Transformer within 7 days after discovery.

(D) Register the PCB Transformer in writing with fire response personnel with primary jurisdiction and with the building owner, within 30 days of discovery.

(E) Install electrical protective equipment on a radial PCB Transformer and a nonsidewalk vault, lower secondary voltage network PCB Transformer in or near a commercial building within 18 months of discovery or by October 1, 1990, whichever is later.

(F) Remove a non-sidewalk vault, lower secondary voltage network PCB Transformer in or near a commercial building, if electrical protective equipment is not installed, within 18 months of discovery or by October 1 , 1993, whichever is later.

(G) Remove a lower secondary voltage network PCB Transformer located in a sidewalk vault in or near a commercial building, within 18 months of discovery or by October 1, 1993, whichever is later.

(H) Retrofill and reclassify a radial PCB Transformer or a lower or higher secondary voltage network PCB Transformer, located in other than a sidewalk vault in or near a commercial building, within 18 months or by October 1, 1990, whichever is later. This is an option in lieu of installing electrical protective equipment on a radial or lower secondary voltage network PCB Transformer located in other than a sidewalk vault or of removing a higher secondary voltage network PCB Transformer or a lower secondary voltage network PCB Transformer, located in a sidewalk vault, from service.

(I) Retrofill and reclassify a lower secondary voltage network PCB Transformer, located in a sidewalk vault, in or near a commercial building within 18 months or by October 1, 1993, whichever is later. This is an option in lieu of installing electrical protective equipment or removing the transformer from service.

(J) Retrofill and reclassify a higher secondary voltage network PCB Transformer, located in a sidewalk vault, in or near a commercial building within 18 months or by October 1, 1990, whichever is later. This is an option in lieu of other requirements.

(2) Servicing conditions.

(i) Transformers classified as PCBContaminated Electrical Equipment (as defined in the definition of "PCBContaminated Electrical Equipment" under $\$ 761.3$ ) may be serviced (including rebuilding) only with dielectric fluid containing less than $500 \mathrm{ppm}$ PCB. 
(ii) Any servicing (including rebuilding) of PCB Transformers (as defined in the definition of "PCB Transformer" under $\$ 761.3)$ that requires the removal of the transformer coil from the transformer casing is prohibited. PCB Transformers may be serviced (including topping off) with dielectric fluid at any PCB concentration.

(iii) PCBs removed during any servicing activity must be captured and either reused as dielectric fluid or disposed of in accordance with the requirements of $\$ 761.60$. PCBs from PCB Transformers must not be mixed with or added to dielectric fluid from PCBContaminated Electrical Equipment.

(iv) Regardless of its PCB concentration, dielectric fluids containing less than $500 \mathrm{ppm}$ PCB that are mixed with fluids that contain 500 ppm or greater PCB must not be used as dielectric fluid in any electrical equipment. The entire mixture of dielectric fluid must be considered to be greater than 500 ppm PCB and must be disposed of in an incinerator that meets the requirements in $\$ 761.70$.

(v) A PCB Transformer may be converted to PCB-Contaminated Electrical Equipment or to a non-PCB Transformer and a transformer that is classified as PCBContaminated Electrical Equipment may be reclassified to a non-PCB Transformer by draining, refilling and/or otherwise servicing the transformer. In order to reclassify, the transformer's dielectric fluid must contain less than $500 \mathrm{ppm}$ PCB (for conversion to PCB-Contaminated Electrical Equipment) or less than $50 \mathrm{ppm}$ PCB (for conversion to a non-PCB Transformer) after a minimum of three months of in-service use subsequent to the last servicing conducted for the purpose of reducing the PCB con- centration in the transformer. In-service means that the transformer is used electrically under loaded conditions that raise the temperature of the dielectric fluid to at least 50/ Centigrade. The Director, Chemical Management Division may grant, without further rulemaking, approval for the use of alternative methods that simulate the loaded conditions of in-service use. All PCBs removed from transformers for purposes of reducing $\mathrm{PCB}$ concentrations are subject to the disposal requirements of $\$ 761.60$.

(vi) Any dielectric fluid containing $50 \mathrm{ppm}$ or greater PCB used for servicing transformers must be stored in accordance with the storage for disposal requirements of $\$ 761.65$. (vii) Processing and distribution in commerce of PCBs for purposes of servicing transformers is permitted only for persons who are granted an exemption under TSCA 6(e)(3)(B).

(b) Use in and servicing of railroad transformers. PCBs may be used in transformers in railroad locomotives or railroad self-propelled cars ("railroad transformers") and may be processed and distributed in commerce for purposes of servicing these transformers in a manner other than a totally enclosed manner subject to the following conditions:

(1) Use restrictions.

(i) After July 1, 1983, the number of railroad transformers containing a PCB concentration greater than $60,000 \mathrm{ppm}(6.0$ percent on a dry weight basis) in use by any affected railroad organization may not exceed two-thirds of the total railroad transformers containing PCBs in use by that organization on January 1, 1982.

(ii) After January 1, 1984, the number of railroad transformers containing a $\mathrm{PCB}$ concentration greater than $60,000 \mathrm{ppm}$ in use by any affected railroad organization may not exceed one-third of the total railroad transformers containing PCBs in use by that organization on January 1, 1982.

(iii) After July 1, 1984, use of railroad transformers that contain dielectric fluids with a PCB concentration greater than 60,000 ppm is prohibited.

(iv) After July 1, 1985, the number of railroad transformers containing a $\mathrm{PCB}$ concentration greater than $1,000 \mathrm{ppm}(0.1$ percent on a dry weight basis) in use by any affected railroad organization may not exceed two-thirds of the total railroad transformers containing PCBs in use by that organization on July $1,1984$.

(v) After January 1, 1986, the number of railroad transformers containing a PCB concentration greater than $1,000 \mathrm{ppm}$ in use by any affected railroad organization may not exceed one-third of the total railroad transformers containing PCBs in use by that organization on July 1,1984 .

(vi) After July 1, 1986, use of railroad transformers that contain dielectric fluids with a PCB concentration greater than 1,000 ppm is prohibited.

(vii) The concentration of PCBs in the dielectric fluid contained in railroad transformers must be measured: 
(A) Immediately upon completion of any authorized servicing of a railroad transformer conducted for the purpose of reducing the PCB concentration in the dielectric fluid in the transformer, and

(B) Between 12 and 24 months after each servicing conducted in accordance with paragraph (b)(1)(vii)(A) of this section;

(C) The data obtained as a result of paragraphs (b)(1)(vii)(A) and (B) of this section shall be retained until January 1, 1991.

(2) Servicing restrictions.

(i) If the coil is removed from the casing of a railroad transformer (e.g., the transformer is rebuilt), after January 1, 1982, the railroad transformer may not be refilled with dielectric fluid containing a PCB concentration greater than $50 \mathrm{ppm}$;

(ii) After January 1, 1982, railroad transformers may only be serviced with dielectric fluid containing less than 60,000 ppm PCBs, except as provided in paragraph (b)(2)(i) of this section;

(iii) After January 1, 1984, railroad transformers may only be serviced with dielectric fluid containing less than $1000 \mathrm{ppm}$ $\mathrm{PCB}$, except as provided in paragraph (b)(2)(i) of this section;

(iv) Dielectric fluid may be filtered through activated carbon or otherwise industrially processed for the purpose of reducing the PCB concentration in the fluid;

(v) Any PCB dielectric fluid that is used to service PCB railroad transformers must be stored in accordance with the storage for disposal requirements of $\$ 761.65$;

(vi) After July 1, 1979, processing and distribution in commerce of PCBs for purposes of servicing railroad transformers is permitted only for persons who are granted an exemption under TSCA section 6(e)(3)(B).

(vii) A PCB Transformer may be converted to a PCB-Contaminated Transformer or to a non-PCB Transformer by draining, refilling, and/or otherwise servicing the railroad transformer. In order to reclassify, the railroad transformer's dielectric fluid must contain less than 500 ppm (for conversion to PCB-Contaminated Transformer) or less than $50 \mathrm{ppm} \mathrm{PCB} \mathrm{(for}$ conversion to a non-PCB Transformer) after a minimum of three months of inservice use subsequent to the last servicing conducted for the purpose of reducing the PCB concentration in the transformer.

(c) Use in and servicing of mining equipment. PCBs may be used in mining equipment and may be processed and distributed in commerce for purposes of servicing mining equipment in a manner other than a totally enclosed manner until January 1, 1982, subject to the following conditions:

(1) PCBs may be added to motors in mining equipment in mines or mining areas until January 1, 1982;

(2) PCB motors in loader-type mining equipment must be rebuilt as air-cooled or other non-PCB-containing motors whenever the motor is returned to a service shop for servicing;

(3) PCB motors in continuous miner-type equipment may be rebuilt as $\mathrm{PCB}$ motors until January 1, 1980;

(4) Any PCBs that are on hand to service or repair mining equipment must be stored in accordance with the storage for disposal requirements of $\$ 761.65$;

(5) After July 1, 1979, processing and distribution in commerce of PCBs for purposes of servicing mining equipment is permitted only for persons who are granted an exemption under TSCA section 6(e)(3)(B).

(d) Use in heat transfer systems. After July 1, 1984, intentionally manufactured PCBs may be used in heat transfer systems in a manner other than a totally enclosed manner at a concentration level of less than $50 \mathrm{ppm}$ provided that the requirements of paragraphs (d)(1) through (5) of this section are met.

(1) Each person who owns a heat transfer system that ever contained PCBs at concentrations above $50 \mathrm{ppm}$ must test for the concentration of PCBs in the heat transfer fluid of such a system no later than November 1,1979 , and at least annually thereafter. All test sampling must be performed at least three months after the most recent fluid refilling. When a test shows that the PCB concentration is less than $50 \mathrm{ppm}$, testing under this paragraph is no longer required.

(2) Within six months of a test performed under paragraph (d)(1) of this section that indicates that a system's fluid contains $\mathbf{5 0}$ ppm or greater PCB $(0.005 \%$ on a dry weight basis), the system must be drained of the PCBs and refilled with fluid containing less than $50 \mathrm{ppm}$ PCB. Topping-off with heat transfer fluids containing PCB concentrations of less than $50 \mathrm{ppm}$ is permitted.

(3) After November 1, 1979, no heat transfer system that is used in the manufacture or processing of any food, drug, cosmetic or device, as defined in section 201 of the Federal Food, Drug, and Cosmetic Act, may 
contain transfer fluid with 50 ppm or greater PCB $(0.005 \%$ on a dry weight basis).

(4) Addition of fluids containing PCB concentrations greater than $50 \mathrm{ppm}$ is prohibited.

(5) Data obtained as a result of paragraph (d)(1) of this section must be retained for five years after the heat transfer system reaches $\mathbf{5 0}$ ppm PCB.

(e) Use in hydraulic systems. After July 1, 1984 , intentionally manufactured PCBs may be used in hydraulic systems in a manner other than a totally enclosed manner at a concentration level of less than $50 \mathrm{ppm}$ provided that the requirements in paragraphs (e)(1) through (5) of this section are met.

(1) Each person who owns a hydraulic system that ever contained PCBs at concentrations above $50 \mathrm{ppm}$ must test for the concentration of PCBs in the hydraulic fluid of each system no later than November 1, 1979 , and at least annually thereafter. All test sampling must be performed at least three months after the most recent fluid refilling. When a test shows that the PCB concentration is less than $50 \mathrm{ppm}$, testing under this paragraph is no longer required.

(2) Within six months of a test under paragraph (e)(1) of this section that indicates that a system's fluid contains $50 \mathrm{ppm}$ or greater PCB ( $0.005 \%$ on a dry weight basis), the system must be drained of the PCBs and refilled with fluid containing less than $50 \mathrm{ppm}$ PCB. Topping-off with hydraulic fluids containing PCB concentrations less than 50 ppm to reduce PCB concentrations is permitted.

(3) Addition of PCBs at concentrations of greater than $50 \mathrm{ppm}$ is prohibited.

(4) Hydraulic fluid may be drained from a hydraulic system and filtered, distilled, or otherwise serviced in order to reduce the PCB concentration below $50 \mathrm{ppm}$.

(5) Data obtained as a result of paragraph (e)(1) of this section must be retained for five years after the hydraulic system reaches 50 ppm.

(f) Use in carbonless copy paper. Carbonless copy paper containing PCBs may be used in a manner other than a totally enclosed manner indefinitely.

(g) Pigments. Diarylide and Phthalocyanin pigments that contain $50 \mathrm{ppm}$ or greater PCB may be processed, distributed in commerce, and used in a manner other than a totally enclosed manner until January 1,1982 , except that after July 1, 1979, pro- cessing and distribution in commerce of diarylide or phthalocyanin pigments that contain $50 \mathrm{ppm}$ or greater PCB is permitted only for persons who are granted an exemption under TSCA section $6(\mathrm{e})(3)(\mathrm{B})$.

(h) Use in and servicing of electromagnets, switches and voltage regulators. PCBs at any concentration may be used in electromagnets, switches (including sectionalizers and motor starters), and voltage regulators and may be used for purposes of servicing this equipment (including rebuilding) for the remainder of their useful lives, subject to the following conditions:

(1) Use conditions.

(i) After October 1, 1985, the use and storage for reuse of any electromagnet which poses an exposure risk to food or feed is prohibited if the electromagnet contains greater than 500 ppm PCBs.

(ii) A visual inspection of each electromagnet subject to paragraph $(h)(1)(i)$ of this section, shall be performed at least once every week according to the conditions contained in $\$ 761.30(\mathrm{a})(1)$ (iii) and (iv).

(2) Servicing conditions.

(i) Servicing (including rebuilding) any electromagnet, switch, or voltage regulator with a PCB concentration of $500 \mathrm{ppm}$ or greater which requires the removal and rework of the internal components is prohibited.

(ii) Electromagnets, switches, and voltage regulators classified as PCB-Contaminated Electrical Equipment (as defined in the definition of "PCB-Contaminated Electrical Equipment" under \$761.3) may be serviced (including rebuilding) only with dielectric fluid containing less than 500 ppm PCB.

(iii) $\mathrm{PCBs}$ removed during any servicing activity must be captured and either reused as dielectric fluid or disposed of in accordance with the requirements of $\$ 761.60$. PCBs from electromagnets switches, and voltage regulators with a PCB concentration of at least 500 ppm must not be mixed with or added to dielectric fluid from PCBContaminated Electrical Equipment.

(iv) Regardless of its PCB concentration, dielectric fluids containing less than $500 \mathrm{ppm}$ PCB that are mixed with fluids that contain 500 ppm or greater PCB must not be used as dielectric fluid in any electrical equipment. The entire mixture of dielectric fluid must be considered to be greater than 500 ppm PCB and must be disposed of in an incinerator that meets the requirements of $\$ 761.70$. 
(v) An electromagnet, switch or voltage regulator with a PCB concentration of at least $500 \mathrm{ppm}$ may be converted to PCBContaminated Electrical Equipment or to a non-PCB classification and PCB-Contaminated Electrical Equipment may be reclassified to a non-PCB classification by draining, refilling and/or otherwise servicing the equipment. In order to be reclassified, the equipment's dielectric fluid must contain less than $500 \mathrm{ppm}$ PCB (for conversion to PCB-Contaminated Electrical Equipment) or less than $50 \mathrm{ppm}$ PCB (for conversion to a non-PCB classification) after a minimum of three months of in-service use subsequent to the last servicing conducted for the purpose of reducing the PCB concentration in the equipment. In-service use means the equipment is used electrically under loaded conditions. The Assistant Administrator may grant, without further rulemaking, approval for the use of alternative methods that simulate the loaded conditions of in-service use. All PCBs removed from this equipment for purposes of reducing PCB concentrations are subject to the disposal requirements of $\$ 761.60$.

(vi) Any dielectric fluid containing $50 \mathrm{ppm}$ or greater PCB used for servicing electromagnets, switches, or voltage regulators must be stored in accordance with the storage for disposal requirements of $\$ 761.65$.

(vii) Processing and distribution in commerce of PCBs for purposes of servicing electromagnets, switches or voltage regulators is permitted only for persons who are granted an exemption under TSCA $6(\mathrm{e})(3)(\mathrm{B})$.

(i) Use in compressors and in the liquid of natural gas pipelines. PCBs may be used indefinitely in the compressors and in the liquids of natural gas pipelines at a concentration level of less than $50 \mathrm{ppm}$ provided that they are marked in accordance with \$761.45(a).

(j) Small quantities for research and development. PCBs may be used in small quantities for research and development, as defined in $\$ 761.3$, in a manner other than a totally enclosed manner, indefinitely. Manufacture, processing, and distribution in commerce of PCBs in small quantities for research and development is permitted only for persons who have been granted an exemption under TSCA section 6(e)(3)(B). (k) Microscopy mounting medium. PCBs may be used as a permanent microscopic mounting medium in a manner other than a totally enclosed manner indefinitely. Manufacture, processing, and distribution in commerce of PCBs for purposes of use as a mounting medium are permitted only for persons who are granted an exemption under TSCA section 6(e)(3)(B).

(1) Use in capacitors. PCBs at any concentration may be used in capacitors, subject to the following conditions:

(1) Use conditions.

(i) After October 1, 1988, the use and storage for reuse of PCB Large High Voltage Capacitors and PCB Large Low Voltage Capacitors which pose an exposure risk to food or feed is prohibited.

(ii) After October 1, 1988, the use of PCB Large High Voltage Capacitors and PCB Large Low Voltage Capacitors is prohibited unless the capacitor is used within a restricted-access electrical substation or in a contained and restricted-access indoor installation. A restricted-access electrical substation is an outdoor, fenced or walled-in facility that restricts public access and is used in the transmission or distribution of electric power. A contained and restricted-access indoor installation does not have public access and has an adequate roof, walls, and floor to contain any release of PCBs within the indoor location.

(2) [Reserved]

(m) Use in and servicing of circuit breakers, reclosers and cable. PCBs at any concentration may be used in circuit breakers, reclosers, and cable and may be used for purposes of servicing this electrical equipment (including rebuilding) for the remainder of their useful lives, subject to the following conditions:

(1) Servicing conditions.

(i) Circuit breakers, reclosers, and cable may be serviced (including rebuilding) only with dielectric fluid containing less than $\mathbf{5 0}$ ppm PCB.

(ii) Any circuit breaker, recloser or cable found to contain at least $50 \mathrm{ppm}$ PCBs may be serviced only in accordance with the conditions contained in 40 CFR 761.30(h)(2).

(2) [Reserved]

(n) Microscopy immersion oil. PCBs may be used as an immersion oil in fluorescence microscopy, in a manner other than a totally enclosed manner indefinitely. Manufacture, processing, and distribution in commerce of 
PCBs for purposes of use as a low fluorescence immersion oil are permitted only for persons who are granted an exemption under TSCA section 6(e)(3)(B).

(o) Optical liquids. PCBs may be used as optical liquids in a manner other than a totally enclosed manner indefinitely. Manufacture, processing, and distribution in commerce of PCBs for purposes of use as optical liquids are permitted only for persons who are granted an

Added 59 FR 16998 April 11, 1994 exemption under TSCA section 6(e)(3)(B).

(p) Analytical reference samples. PCBs in analytical reference samples derived from waste materials may be used only when the samples originated from a person who has been granted an exemption to process and distribute in commerce such samples under TSCA section 6(e)(3)(B). Once the use of such samples is completed, disposal of such samples is governed by all applicable Federal, State, and local laws, including the rules contained in this part.

(Sec. 6, Pub. L. 94-469, 90 Stat. 2020, 2025 (15 U.S.C. 2605)

[44 FR 31542, May 31; 1979. Redesignated at 47 FR 19527, May 6, 1982, and amended at 47 FR 37357, Aug. 25,$1983 ; 48$ FR 135, Jan. 3, 1983; 49 FR 25241 and 25242 , June 20,$1984 ; 49$ FR 28190 , and 28202 , July 10 , 1984; 50 FR 29199, July 17, 1985; 53 FR 12524, Apr. 15,1988 ; 53 FR 24221, June 27, 1988; 53 FR 27328 , July 19, 1988; 54 FR 28419, July 6, 1989; 55 FR 45804, Oct 31,1990 ; 55 FR 49045, Nov. 26, 1990; 58 FR 15809, Mar. 24, 1993; 58 FR 34205, June 23, 1993; 59 FR 16998 , Apr. 11, 1994]

\section{Subpart C-Marking of PCBs and PCB Items}

\section{$\$ 761.40$ Marking requirements.}

(a) Each of the following items in existence on or after July 1, 1978 shall be marked as illustrated in Figure 1 in \$761.45(a): The mark illustrated in Figure 1 is referred to as $M_{L}$ throughout this subpart.

(1) PCB Containers;

(2) PCB Transformers at the time of manufacture, at the time of distribution in commerce if not already marked, and at the time of removal from use if not already marked. [Marking of PCB-Contaminated Electrical Equipment is not required];

(3) PCB Large High Voltage Capacitors at the time of manufacture, at the time of distribution in commerce if not already marked, and at the time of removal from use if not already marked;

(4) Equipment containing a PCB Transformer or a PCB Large High Voltage Capacitor at the time of manufacture, at the time of distribution in commerce if not already marked, and at the time of removal of the equipment from use if not already marked;

(5) PCB Large Low Voltage Capacitors at the time of removal from use;

(6) Electric motors using PCB coolants (See also paragraph (e) of this section).

(7) Hydraulic systems using PCB hydraulic fluid (See also paragraph (e) of this section);

(8) Heat transfer systems (other than PCB Transformers) using PCBs (See also paragraph (e) of this section);

(9) PCB Article Containers containing articles or equipment that must be marked under paragraphs (a) (1) through (8) of this section;

(10) Each storage area used to store PCBs and PCB Items for disposal.

(b) As of October 1, 1978, each transport vehicle shall be marked on each end and side with $\mathrm{M}_{\mathrm{L}}$ as described in $\$ 761.45$ (a) if it is loaded with PCB Containers that contain more than $45 \mathrm{~kg}$ (99.4 lbs.) of PCBs in the liquid phase or with one or more PCB Transformers (See also paragraph (e) of this section).

(c) As of January 1, 1979, the following PCB Articles shall be marked with mark $M_{\mathrm{L}}$ as described in $\$ 761.45(\mathrm{a})$ :

(1) All PCB Transformers not marked under paragraph (a) of this section [marking of PCB-Contaminated Electrical Equipment is not required];

(2) All PCB Large High Voltage Capacitors not marked under paragraph (a) of this section

(i) Will be marked individually with mark ML, or

(ii) If one or more PCB Large High Voltage Capacitors are installed in a protected location such as on a power pole, or structure, or behind a fence; the pole, structure, or fence shall be marked with mark $M_{L}$, and a record or procedure identifying the PCB Capacitors shall be maintained by the owner or operator at the protected location.

(d) As of January 1, 1979, all PCB Equipment containing a PCB Small Capacitor shall be marked at the time of manufacture with the statement, "This equipment contains PCB Capacitor(s)". The mark shall be of the same size as the mark $\mathrm{M}_{\mathrm{L}}$.

(e) As of October 1, 1979, applicable PCB Items in paragraphs (a) (1), (6), (7), and (8) of this section containing PCBs in concentrations of 50 to $500 \mathrm{ppm}$ and applicable 
transport vehicles in paragraph (b) of this section loaded with PCB Containers that contain more than $45 \mathrm{~kg}$ (99.4 lbs.) of liquid PCBs in concentrations of $50 \mathrm{ppm}$ to $500 \mathrm{ppm}$ shall be marked with mark $M_{L}$ as described in $\$ 761.45(\mathrm{a})$.

(f) Where mark $M_{L}$ is specified but the PCB Article or PCB Equipment is too small to accommodate the smallest permissible size of mark $M_{L}$, mark $M_{S}$ as described in $\$ 761.45(\mathrm{~b})$, may be used instead of mark $\mathrm{M}_{\mathrm{L}}$.

(g) Each large low voltage capacitor, each small capacitor normally used in alternating current circuits, and each fluorescent light ballast manufactured ("manufactured", for purposes of this sentence, means built) between July 1, 1978 and July 1, 1998 that do not contain PCBs shall be marked by the manufacturer at the time of manufacture with the statement, "No PCBs". The mark shall be of similar durability and readability as other marking that indicate electrical information, part numbers, or the manufacturer's name. For purposes of this paragraph marking requirement only is applicable to items built domestically or abroad after June 30, 1978.

(h) All marks required by this subpart must be placed in a position on the exterior of the PCB Items or transport vehicles so that the marks can be easily read by any persons inspecting or servicing the marked PCB Items or transport vehicles.

(i) Any chemical substance or mixture that is manufactured after the effective date of this rule and that contains less than $500 \mathrm{ppm}$ PCB ( $0.05 \%$ on a dry weight basis), including PCB that is a byproduct or impurity, must be marked in accordance with any requirements contained in the exemption granted by EPA to permit such manufacture and is not subject to any other requirement in this subpart unless so specified in the exemption. This paragraph applies only to containers of chemical substances or mixtures. PCB articles and equipment into which the chemical substances or mixtures are processed, are subject to the marking requirements contained elsewhere in this subpart.

(j) PCB Transformer locations shall be marked as follows:

(1) Except as provided in paragraph (j)(2) of this section, as of December 1, 1985, the vault door, machinery room door, fence, hallway, or means of access, other than grates and manhole covers, to a PCB Transformer must be marked with the mark $\mathrm{ML}_{\mathrm{L}}$ as required by paragraph (a) of this section.
(2) A mark other than the ML mark may be used provided all of the following conditions are met:

(i) The program using such an alternative mark was initiated prior to August 15, 1985, and can be substantiated with documentation.

(ii) Prior to August 15, 1985, coordination between the transformer owner and the primary fire department occurred, and the primary fire department knows, accepts, and recognizes what the alternative mark means, and that this can be substantiated with documentation.

(iii) The EPA Regional Administrator in the appropriate region is informed in writing of the use of the alternative mark by October 3,1988 and is provided with documentation that the program began before August 15, 1985, and documentation that demonstrates that prior to that date the primary fire department knew, accepted and recognized the meaning of the mark, and included this information in firefighting training.

(iv) The Regional Administrator will either approve or disapprove in writing the use of an alternative mark within $\mathbf{3 0}$ days of receipt of the documentation of a program.

(3) Any mark placed in accordance with the requirements of this section must be placed in the locations described in paragraph (j)(1) of this section and in a manner that can be easily read by emergency response personnel fighting a fire involving this equipment.

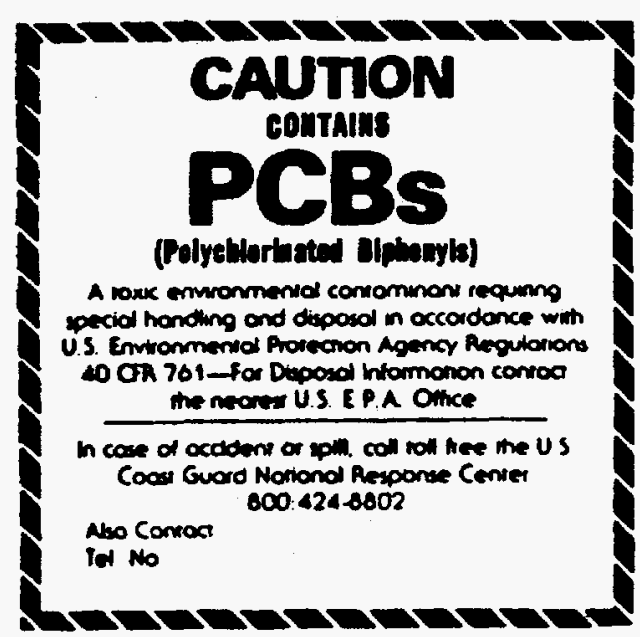

Figure 1 


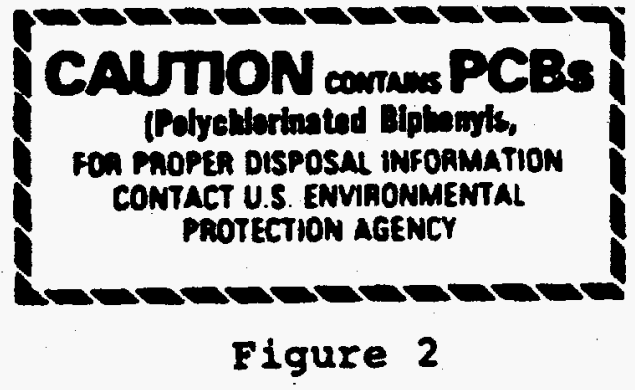

[44 FR 31542, May 31, 1979. Redesignated at 47 FR 19527, May 6, 1982, and amended at 47 FR 37359, Aug. 25,$1982 ; 50$ FR 29201 , July 17, 1985; 50 FR 32176, Aug. 9, 1985; 53 FR 12524, Apr. 15, 1988; 53 FR 27329, July $19,1988]$

\section{\$761.45 Marking formats.}

The following formats shall be used for marking:

(a) Large PCB Mark-ML. Mark ML shall be as shown in Figure 1, letters and striping on a white or yellow background and shall be sufficiently durable to equal or exceed the life (including storage for disposal) of the PCB Article, PCB Equipment, or PCB Container. The size of the mark shall be at least $15.25 \mathrm{~cm}$ ( 6 inches) on each side. If the PCB Article or PCB Equipment is too small to accommodate this size, the mark may be reduced in size proportionately down to a minimum of $5 \mathrm{~cm}$ (2 inches) on each side.

(b) Small PCB Mark--Ms. Mark $\mathbf{M}_{\mathbf{s}}$ shall be as shown in Figure 2, letters and striping on a white or yellow background, and shall be sufficiently durable to equal or exceed the life (including storage for disposal) of the PCB Article, PCB Equipment, or PCB Container. The mark shall be a rectangle 2.5 by $5 \mathrm{~cm}$ ( 1 inch by 2 inches). If the PCB Article or PCB Equipment is too small to accommodate this size, the mark may be reduced in size proportionately down to a minimum of 1 by $2 \mathrm{~cm}$ (.4 by .8 inches).

[44 FR 31542, May 31, 1979. Redesignated at 47 FR 19527, May 6, 1982]

\section{Subpart D-Storage and Disposal}

Note: This subpart does not require removal of PCBs and PCB Items from service and disposal earlier than would normally be the case. However, when PCBs and PCB Items are removed from service and disposed of, disposal must be undertaken in accordance with these regulations. PCBs (including soils and debris) and PCB Items which have been placed in a disposal site are considered to be "in service" for purposes of the applicability of this subpart. This subpart does not require PCBs and PCB Items landfilled prior to February 17, 1978 to be removed for disposal. However, if such PCBs or PCB Items are removed from the disposal site, they must be disposed of in accordance with this subpart. Other subparts are directed to the manufacture, processing, distribution in commerce, and use of PCBs and may result in some cases in disposal at an earlier date than would otherwise occur.

\section{$\$ 761.60$ Disposal requirements.}

(a) PCBs.

(1) Except as provided in paragraphs (a)(2), (3), (4), and (5) of this section, PCBs at concentrations of $50 \mathrm{ppm}$ or greater must be disposed of in an incinerator which complies with $\$ 761.70$.

(2) Mineral oil dielectric fluid from PCB-Contaminated Electrical Equipment containing a PCB concentration of $50 \mathrm{ppm}$ or greater, but less than 500 ppm, must be disposed of in one of the following:

(i) In an incinerator that complies with $\$ 761.70$;

(ii) In a chemical waste landfill that complies with $\$ 761.75$ if information is provided to the owner or operator of the chemical waste landfill that shows that the mineral oil dielectric fluid does not exceed 500 ppm PCB and is not an ignitable waste as described in $\$ 761.75(\mathrm{~b})(8)$ (iii);

(iii) In a high efficiency boiler provided that:

(A) The boiler complies with the following criteria:

(1) The boiler is rated at a minimum of 50 million BTU hours;

(2) If the boiler uses natural gas or oil as the primary fuel, the carbon monoxide concentration in the stack is 50 ppm or less and the excess oxygen is at least three (3) percent when PCBs are being burned;

(3) If the boiler uses coal as the primary fuel, the carbon monoxide concentration in the stack is $100 \mathrm{ppm}$ or less and the excess oxygen is at least three (3) percent when PCBs are being burned;

(4) The mineral oil dielectric fluid does not comprise more than ten (10) percent (on a volume basis) of the total fuel feed rate;

(5) The mineral oil dielectric fluid is not fed into the boiler unless the boiler is operating at its normal operating temperature (this prohibits feeding these fluids during either start up or shut down operations); 
(6) The owner or operator of the boiler:

(i) Continuously monitors and records the carbon monoxide concentration and excess oxygen percentage in the stack gas while burning mineral oil dielectric fluid; or

(ii) If the boiler will burn less than 30,000 gallons of mineral oil dielectric fluid per year, measures and records the carbon monoxide concentration and excess oxygen percentage in the stack gas at regular intervals of no longer than 60 minutes while burning mineral oil dielectric fluid.

(7) The primary fuel feed rates, mineral oil dielectric fluid feed rates, and total quantities of both primary fuel and mineral oil dielectric fluid fed to the boiler are measured and recorded at regular intervals of no longer than 15 minutes while burning mineral oil dielectric fluid.

(8) The carbon monoxide concentration and the excess oxygen percentage are checked at least once every hour that mineral oil dielectric fluid is burned. If either measurement falls below the levels specified in this rule, the flow of mineral oil dielectric fluid to the boiler shall be stopped immediately.

(B) Thirty days before any person burns mineral oil dielectric fluid in the boiler, the person gives written notice to the EPA Regional Administrator for the EPA Region in which the boiler is located and that the notice contains the following information:

(1) The name and address of the owner or operator of the boiler and the address of the boiler;

(2) The boiler rating in units of BTU/hour;

(3) The carbon monoxide concentration and the excess oxygen percentage in the stack of the boiler when it is operated in a manner similar to the manner in which it will be operated when mineral oil dielectric fluid is burned; and

(4) The type of equipment, apparatus, and procedures to be used to control the feed of mineral oil dielectric fluid to the boiler and to monitor and record the carbon monoxide concentration and excess oxygen percentage in the stack.

(C) When burning mineral oil dielectric fluid, the boiler must operate at a level of output no less than the output at which the measurements required under paragraph (a)(2)(iii)(B)(3) of this section were taken.

(D) Any person burning mineral oil dielectric fluid in a boiler obtains the following information and retains the information for five years at the boiler location:

(1) The data required to be collected under paragraphs (a)(2)(A) (6) and (7) of this section; and

(2) The quantity of mineral oil dielectric fluid burned in the boiler each month;

(iv) In a facility that is approved in accordance with $\$ 761.60(\mathrm{e})$. For the purpose of burning mineral oil dielectric fluid, an applicant under $\$ 761.60(\mathrm{e})$ must show that his combustion process destroys PCBs as efficiently as does a high efficiency boiler, as defined in paragraph (a)(2)(iii) of this section, or a $\$ 761.70$ approved incinerator.

(3) Liquids, other than mineral oil dielectric fluid, containing a PCB concentration of $50 \mathrm{ppm}$ or greater, but less than $500 \mathrm{ppm}$, shall be disposed of:

(i) In an incinerator which complies with $\$ 761.70$;

(ii) In a chemical waste landfill which complies with $\$ 761.75$ if information is provided to the owner or operator of the chemical waste landfill that shows that the waste does not exceed $500 \mathrm{ppm}$ PCB and is not an ignitable waste as described in $\$ 761.75$ (b)(8)(iii); that.

(iii) In a high efficiency boiler provided

(A) The boiler complies with the following criteria:

(1) The boiler is rated at a minimum of 50 million BTU/hour;

(2) If the boiler uses natural gas or oil as the primary fuel, the carbon monoxide concentration in the stack is $50 \mathrm{ppm}$ or less and the excess oxygen is at least three (3) percent when PCBs are being burned;

(3) If the boiler uses coal as the primary fuel, the carbon monoxide concentration in the stack is $100 \mathrm{ppm}$ or less and the excess oxygen is at least three (3) percent when PCBs are being burned;

(4) The waste does not comprise more than ten (10) percent (on a volume basis) of the total fuel feed rate;

(5) The waste is not fed into the boiler unless the boiler is operating at its normal operating temperature (this prohibits feeding these fluids during either start up or shut down operations);

(6) The owner or operator of the boiler must:

(i) Continuously monitor and record the carbon monoxide concentration and excess 
oxygen percentage in the stack gas while burning waste fluid; or

(ii) If the boiler will burn less than 30,000 gallons of waste fluid per year, measure and record the carbon monoxide concentration and excess oxygen percentage in the stack gas at regular intervals of no longer than 60 minutes while burning waste fluid;

(7) The primary fuel feed rate, waste fluid feed rate, and total quantities of both primary fuel and waste fluid fed to the boiler must be measured and recorded at regular intervals of no longer than 15 minutes while burning waste fluid; and

(8) The carbon monoxide concentration and the excess oxygen percentage must be checked at least once every hour that the waste is burned. If either measurement falls below the levels specified in this rule, the flow of waste to the boiler shall be stopped immediately.

(B) Prior to any person burning these liquids in the boiler, approval must be obtained from the EPA Regional Administrator for the EPA Region in which the boiler is located and any persons seeking such approval must submit to the EPA Regional Administrator a request containing at least the following information:

(1) The name and address of the owner or operator of the boiler and the address of the boiler;

(2) The boiler rating in units of BTU/hour;

(3) The carbon monoxide concentration and the excess oxygen percentage in the stack of the boiler when it is operated in a manner similar to the manner in which it will be operated when low concentration PCB liquid is burned;

(4) The type of equipment, apparatus, and procedures to be used to control the feed of mineral oil dielectric fluid to the boiler and to monitor and record the carbon monoxide concentration and excess oxygen percentage in the stack;

(5) The type of waste to be burned (e.g., hydraulic fluid, contaminated fuel oil, heat transfer fluid, etc.);

(6) The concentration of PCBs and of any other chlorinated hydrocarbon in the waste and the results of analyses using the American Society of Testing and Materials (ASTM) methods as follows: Carbon and hydrogen content using ASTM D-3178-84, nitrogen content using ASTM E-258-67 (Reapproved 1987), sulfur content using ASTM D-2784-89, ASTM D-1266-87, or D-129-64, chlorine content using ASTM D-808-87, water and sediment content using either ASTM D-2709-88 or ASTM D-1796-83 (Reapproved 1990), ash content using D-482-87, calorific value using ASTM D-240-87, carbon residue using either ASTM D-2158-89 or D-524-88, and flash point using ASTM D-93-90.

(7) The quantity of wastes estimated to be burned in a thirty (30) day period;

(8) An explanation of the procedures to be followed to insure that burning the waste will not adversely affect the operation of the boiler such that combustion efficiency will decrease.

(C) On the basis of the information in paragraph (a)(3)(iii)(B) of this section and any other available information, the Regional Administrator may, at his discretion, find that the alternate disposal method will not present an unreasonable risk of injury to health or the environment and approve the use of the boiler;

(D) When burning PCB wastes, the boiler must operate at a level of output no less than the output at which the measurements required under paragraph (a)(3)(iii)(B)(3) of this section were taken; and

(E) Any person burning liquids in boilers approved as provided in paragraph (a)(3)(iii)(C) of this section, must obtain the following information and retain the information for five years at the boiler location:

(1) The data required to be collected in paragraphs (a)(3)(iii)(A) (6) and (7) of this section;

(2) The quantity of low concentration PCB liquid burned in the boiler each month.

(3) The analysis of the waste required by paragraph $(a)(3)($ iii)(B)(6) of this section taken once a month for each month during which low concentration PCB liquid is burned in the boiler.

(iv) In a facility that is approved in accordance with $\$ 761.60(\mathrm{e})$. For the purpose of burning liquids, other than mineral oil dielectric fluid, containing $50 \mathrm{ppm}$ or greater PCB, but less than 500 ppm PCB, an applicant under $\$ 761.60$ (e) must show that his combustion process destroys PCBs as efficiently as does a high efficiency boiler, as defined in $\$ 761.60(\mathrm{a})(2)$ (iii), or a $\$ 761.70$ incinerator.

(4) Any non-liquid PCBs at concentrations of $50 \mathrm{ppm}$ or greater in the form of 
contaminated soil, rags, or other debris shall be disposed of:

(i) In an incinerator which complies with $\$ 761.70$; or

(ii) In a chemical waste landfill which complies with $\$ 761.75$.

Note: Except as provided in $\$ 761.75(\mathrm{~b})(8)$ (ii), liquid PCBs shall not be processed into non-liquid forms to circumvent the high temperature incineration requirements of $\$ 761.60(a)$.

(5) All dredged materials and municipal sewage treatment sludges that contain PCBs at concentrations of $50 \mathrm{ppm}$ or greater shall be disposed of:

(i) In an incinerator which complies with $\$ 761.70$,

(ii) In a chemical waste landfill which complies with $\$ 761.75$; or

(iii) Upon application, using a disposal method to be approved by the Agency's Regional Administrator in the EPA Region in which the PCBs are located. Applications for disposal in a manner other than prescribed in paragraph (a)(5) (i) or (ii) of this section must be made in writing to the Regional Administrator. The application must contain information that, based on technical, environmental, and economic considerations, indicates that disposal in an incinerator or chemical waste landfill is not reasonable and appropriate, and that the alternate disposal method will provide adequate protection to health and the environment. The Regional Administrator may request other information that he or she believes to be necessary for evaluation of the alternate disposal method. Any approval by the Regional Administrator shall be in writing and may contain any appropriate limitations on the approved alternate method for disposal. In addition to these regulations, the Regional Administrator shall consider other applicable Agency guidelines, criteria, and regulations to ensure that the discharges of dredged material and sludges that contain PCBs and other contaminants are adequately controlled to protect the environment. The person to whom such approval is issued must comply with all limitations contained in the approval.

(6) When storage is desired prior to disposal, PCBs at concentrations of $50 \mathrm{ppm}$ or greater shall be stored in a facility which complies with $\$ 761.65$.

(b) PCB Articles-

(1) Transformers.

(i) PCB Transformers shall be disposed of in accordance with either of the following:
(A) In an incinerator that complies with $\$ 761.70$; or

(B) In a chemical waste landfill which complies with $\$ 761.75$; Provided, That the transformer is first drained of all free flowing liquid, filled with solvent, allowed to stand for at least 18 hours, and then drained thoroughly. PCB liquids that are removed shall be disposed of in accordance with paragraph (a) of this section. Solvents may include kerosene, xylene, toluene and other solvents in which PCBs are readily soluble. Precautionary measures should be taken, however, that the solvent flushing procedure is conducted in accordance with applicable safety and health standards as required by Federal or State regulations.

(ii) [Reserved]

(2) PCB Capacitors.

(i) The disposal of any capacitor shall comply with all requirements of this subpart unless it is known from label or nameplate information, manufacturer's literature (including documented communications with the manufacturer), or chemical analysis that the capacitor does not contain PCBs.

(ii) Any person may dispose of PCB Small Capacitors as municipal solid waste, unless that person is subject to the requirements of paragraph (b)(2)(iv) of this section.

(iii) Any PCB Large High or Low Voltage Capacitor which contains 500 ppm or greater PCBs, owned by any person, shall be disposed of in accordance with either of the following:

(A) Disposal in an incinerator that complies with $\$ 761.70$; or

(B) Until March 1, 1981, disposal in a chemical waste landfill that complies with $\$ 761.75$.

(iv) Any PCB Small Capacitor owned by any person who manufactures or at any time manufactured PCB Capacitors or PCB Equipment and acquired the PCB Capacitors in the course of such manufacturing shall be disposed of in accordance with either of the following:

(A) Disposal in an incinerator which complies with $\$ 761.70$; or

(B) Until March 1, 1981, disposal in a chemical waste landfill which complies with $\S 761.75$.

(v) Notwithstanding the restrictions imposed by paragraph (b)(2)(iii)(B) or (b)(2)(iv)(B) of this section, PCB capacitors may be disposed of in PCB chemical waste landfills that comply with $\$ 761.75$ 
subsequent to March 1, 1981, if the Assistant Administrator for Pesticides and Toxic Substances publishes a notice in the Federal Register declaring that those landfills are available for such disposal and explaining the reasons for the extension or reopening. An extension or reopening for disposal of PCB capacitors that is granted under this subsection shall be subject to such terms and conditions as the Assistant Administrator may prescribe and shall be in effect for such period as the Assistant Administrator may prescribe. The Assistant Administrator may permit disposal of PCB capacitors in EPA approved chemical waste landfills after March 1, 1981, if in his opinion, (A) Adequate incineration capability for PCB capacitors is not available, or

(B) The incineration of PCB capacitors will significantly interfere with the incineration of liquid PCBs, or

(C) There is other good cause shown.

As part of this evaluation, the Assistant Administrator will consider the impact of his action on the incentives to construct or expand PCB incinerators.

(vi) Prior to disposal in a $\$ 761.75$ chemical waste landfill, all large PCB capacitors, and all small PCB capacitors described in paragraph (b)(2)(iv) of this section, shall be placed in one of the Department of Transportation specification containers identified in $\$ 761.65(c)(6)$ or in containers that comply with 49 CFR 178.118 (specification $17 \mathrm{H}$ containers). Large PCB capacitors which are too big to fit inside one of these containers shall be placed in a container with strength and durability equivalent to the DOT specification containers. In all cases, interstitial space in the container shall be filled with sufficient absorbent material (such as sawdust or soil) to absorb any liquid PCBs remaining in the capacitors.

(3) PCB hydraulic machines. PCB hydraulic machines containing PCBs at concentrations of $50 \mathrm{ppm}$ or greater such as die casting machines may be disposed of as municipal solid waste or salvage provided that the machines are drained of all free-flowing liquid and the liquid is disposed of in accordance with the provisions of paragraph (a) of this section. If the PCB liquid contains $1000 \mathrm{ppm}$ PCB or greater, then the hydraulic machine must be flushed prior to disposal with a solvent containing less than $50 \mathrm{ppm}$ PCB under transformer solvents at paragraph (b)(1)(i)(B) of this section and the solvent disposed of in accordance with paragraph (a) of this section.

(4) PCB-Contaminated Electrical Equipment. All PCB-Contaminated Electrical Equipment except capacitors shall be disposed of by draining all free flowing liquid from the electrical equipment and disposing of the liquid in accordance with paragraph (a)(2) or (3) of this section. The disposal of the drained electrical equipment is not regulated by this rule. Capacitors that contain between 50 and $500 \mathrm{ppm}$ PCBs shall be disposed of in an incinerator that complies with $\$ 761.70$ or in a chemical waste landfill that complies with $\$ 761.75$.

(5) Other PCB Articles.

(i) PCB articles with concentrations at 500 ppm or greater must be disposed of:

(A) In an incinerator that complies with $\$ 761.70$; or

(B) In a chemical waste landfill that complies with $\$ 761.75$, provided that all free-flowing liquid PCBs have been thoroughly drained from any articles before the articles are placed in the chemical waste landfill and that the drained liquids are disposed of in an incinerator that complies with $\$ 761.70$.

(ii) PCB Articles with a PCB concentration between 50 and $500 \mathrm{ppm}$ must be disposed of by draining all free flowing liquid from the article and disposing of the liquid in accordance with paragraph (a)(2) or (3) of this section. The disposal of the drained article is not regulated by this rule.

(6) Storage of PCB Articles. Except for a PCB Article described in paragraph (b)(2)(ii) of this section and hydraulic machines that comply with the municipal solid waste disposal provisions described in paragraph (b)(3) of this section, any PCB Article, with $\mathrm{PCB}$ concentrations at $50 \mathrm{ppm}$ or greater, shall be stored in accordance with $\$ 761.65$ prior to disposal.

(c) PCB Containers.

(1) Unless decon- taminated in compliance with $\$ 761.79$ or as provided in paragraph (c)(2) of this section, a PCB container with $\mathrm{PCB}$ concentrations at $500 \mathrm{ppm}$ or greater shall be disposed of:

(i) In an incinerator which complies with $\$ 761.70$, or

(ii) In a chemical waste landfill that complies with $\$ 761.75$; provided that if there are PCBs in a liquid state, the PCB Container shall first be drained and the PCB liquid 
disposed of in accordance with paragraph (a) of this section.

(2) Any PCB Container used to contain only PCBs at a concentration less than 500 ppm shall be disposed of as municipal solid wastes; provided that if the PCBs are in a liquid state, the PCB Container shall first be drained and the PCB liquid shall be disposed of in accordance with paragraph (a) of this section.

(3) Prior to disposal, a PCB container with $\mathrm{PCB}$ concentrations at $50 \mathrm{ppm}$ or greater shall be stored in a facility which compliès with $\$ 761.65$.

(d) Spills.

(1) Spills and other uncontrolled discharges of PCBs at concentrations of 50 ppm or greater constitute the disposal of PCBs.

(2) PCBs resulting from the clean-up and removal of spills, leaks, or other uncontrolled discharges, must be stored and disposed of in accordance with paragraph (a) of this section.

(3) These regulations do not exempt any person from any actions or liability under other statutory authorities, including but not limited to the Clean Water Act, the Resource Conservation and Recovery Act, and the Comprehensive Environmental Response, Compensation, and Liability Act of 1980.

(e) Any person who is required to incinerate any PCBs and PCB Items under this subpart and who can demonstrate that an alternative method of destroying PCBs and PCB Items exists and that this alternative method can achieve a level of performance equivalent to $\$ 761.70$ incinerators or high efficiency boilers as provided in paragraphs (a)(2)(iv) and (a)(3)(iv) of this section, may submit a written request to either the Regional Administrator or the Director, Chemical Management Division for an exemption from the incineration requirements of $\$ 761.70$ or $\$ 761.60$. Requests for approval of alternate methods that will be operated in more than one region must be submitted to the Director, Chemical Management Division except for research and development involving less than 500 pounds of PCB material (see paragraph (i)(2) of this section). Requests for approval of alternate methods that will be operated in only one region must be submitted to the appropriate Regional Administrator. The applicant must show that his method of destroying PCBs will not present an unreasonable risk of injury to health or the environment. On the basis of such information and any available information, the Regional Administrator or the Director, Chemical Management Division may, in his discretion, approve the use of the alternate method if he finds that the alternate disposal method provides PCB destruction equivalent to disposal in a $\$ 761.70$ incinerator or a $\$ 761.60$ high efficiency boiler and will not present an unreasonable risk of injury to health or the environment. Any approval must be stated in writing and may contain such conditions and provisions as the Regional Administrator or Director, Chemical Management Division deems appropriate. The person to whom such waiver is issued must comply with all limitations contained in such determination.

(f)(1) Each operator of a chemical waste landfill, incinerator, or alternative to incineration approved under paragraph (e) of this section shall give the following written notices to the state and local governments within whose jurisdiction the disposal facility is located:

(i) Notice at least thirty (30) days before a facility is first used for disposal of PCBs required by these regulations; and

(ii) At the request of any state or local government, annual notice of the quantities and general description of PCBs disposed of during the year. This annual notice shall be given no more than thirty (30) days after the end of the year covered.

(iii) The Regional Administrator may reduce the notice period required by paragraph (f)(1)(i) of this section from thirty days to a period of no less than five days in order to expedite interim approval of the chemical waste landfill located in Sedgwick County, Kansas.

(2) Any person who disposes of PCBs under a paragraph (a)(5)(iii) of this section incineration or chemical waste landfilling waiver shall give written notice at least thirty (30) days prior to conducting the disposal activities to the state and local governments within whose jurisdiction the disposal is to take place.

(g) Testing procedures.

(1) Owners or users of mineral oil dielectric fluid electrical equipment may use the following procedures to determine the concentration of PCBs in the dielectric fluid:

(i) Dielectric fluid removed from mineral oil dielectric fluid electrical equipment may be collected in a common container, provided that no other chemical substances or mixtures 
are added to the container. This common container option does not permit dilution of the collected oil. Mineral oil that is assumed or known to contain at least $50 \mathrm{ppm}$ PCBs must not be mixed with mineral oil that is known or assumed to contain less than 50 ppm PCBs to reduce the concentration of PCBs in the common container. If dielectric fluid from untested, oil-filled circuit breakers, reclosers, or cable is collected in a common container with dielectric fluid from other oil-filled electrical equipment, the entire contents of the container must be treated as PCBs at a concentration of at least $50 \mathrm{ppm}$, unless all of the fluid from the other oil-filled electrical equipment has been tested and shown to contain less than $50 \mathrm{ppm}$ PCBs.

(ii) For purposes of complying with the marking and disposal requirements, representative samples may be taken from either the common containers or the individual electrical equipment to determine the PCB concentration, except that if any PCBs at a concentration of $500 \mathrm{ppm}$ or greater have been added to the container or equipment then the total container contents must be considered as having a PCB concentration of $500 \mathrm{ppm}$ or greater for purposes of complying with the disposal requirements of this subpart. For purposes of this subparagraph, representative samples of mineral oil dielectric fluid are either samples taken in accordance with ASTM D 923-86 or ASTM D 93-90 or samples taken from a container that has been thoroughly mixed in a manner such that any PCBs in the container are uniformly distributed throughout the liquid in the container.

(2) Owners or users of waste oil may use the following procedures to determine the PCB concentration of waste oil:

(i) Waste oil from more than one source may be collected in a common container, provided that no other chemical substances or mixtures, such as non-waste oils, are added to the container.

(ii) For purposes of complying with the marking and disposal requirements, representative samples may be taken from either the common containers or the individual electrical equipment to determine the PCB concentration. Except, That if any PCBs at a concentration of $500 \mathrm{ppm}$ or greater have been added to the container or equipment then the total container contents must be considered as having a PCB concentration of $500 \mathrm{ppm}$ or greater for purposes of complying with the disposal requirements of this Subpart. For purposes of this paragraph, representative samples of mineral oil dielectric fluid are either samples taken in accordance with ASTM D 923-86 or ASTM D 923-89 or samples taken from a container that has been thoroughly mixed in a manner such that any PCBs in the container are uniformly distributed throughout the liquid in the container.

(h) Requirements for export and import of PCBs for purposes of disposal and PCB Items for purposes of disposal are found in \$761.20.

(i) Approval authority for disposal methods.

(1) The officials (the Director, Chemical Management Division and the Regional Administrators) designated in $\$ \$ 761.60$ (e) and 761.70(a) and (b) to receive requests for approval of PCB disposal activities are the primary approval authorities for these activities. Notwithstanding, the Director, Chemical Management Division may, at his/her discretion, assign the authority to review and approve any aspect of a disposal system to the Office of Pesticides and Toxic Substances or to a Regional Administrator.

(2) Except for activity authorized under $\$ 761.30(j)$, research and development ( $R$ and D) into PCB disposal methods using a total of less than 500 pounds of PCB material (regardless of PCB concentration) will be reviewed and approved by the appropriate EPA Regional Administrator and research and development using 500 pounds or more of PCB material (regardless of PCB concentration) will be reviewed by the approval authorities set out in $\$ \$ 761.60(\mathrm{e})$ and $761.70(a)$ and (b).

(Sec. 6, Pub. L. 94-469, 90 Stat. 2020 (15 U.S.C. 2605)

[44 FR 31542, May 31, 1979, as amended at 44 FR 54297, Sept. 19, 1979; 45 FR 20475, Mar. 28, 1980. Redesignated at 47FR 19527, May 6, 1982, and amended at 47 FR 37359, Aug. 25, 1982; 48 FR 5730, Feb. 8, 1983; 48 FR 13185, Mar. 30, 1983; 48 FR 15125, Apr. 7, 1983; 49 FR 28191, July 10, 1984; 49 FR 36648, Sept. 19, 1984 53 FR 10391, Mar. 31, 1988; 53 FR 12524, Apr. 15, 1988; 53 FR 21641, June 9, 1988; 54 FR 22595, May 25, 1989 . 57 FR 13323, Apr. 16, 1992; 58 FR 15809, Mar. 24, 1993]

\section{$\$ 761.65$ Storage for disposal.}

This section applies to the storage for disposal of PCBs at concentrations of $50 \mathrm{ppm}$ or greater and PCB Items with PCB concentrations of $50 \mathrm{ppm}$ or greater.

(a) Any PCB Article or PCB Container stored for disposal before January 1, 1983, shall be removed from storage and disposed 
of as required by this part before January 1 , 1984. Any PCB Article or PCB Container stored for disposal after January 1, 1983, shall be removed from storage and disposed of as required by Subpart $D$ of this part within one year from the date when it was first placed into storage.

(b) Except as provided in paragraph (c) of this section, after July 1, 1978, owners or operators of any facilities used for the storage of PCBs and PCB Items designated for disposal shall comply with the following requirements:

(1) The facilities shall meet the following criteria:

(i) Adequate roof and walls to prevent rain water from reaching the stored PCBs and PCB Items;

(ii) An adequate floor which has continuous curbing with a minimum six inch high curb. The floor and curbing must provide a containment volume equal to at least two times the internal volume of the largest PCB Article or PCB Container stored therein or 25 percent of the total internal volume of all $\mathrm{PCB}$ Articles or PCB Containers stored therein, whichever is greater;

(iii) No drain valves, floor drains, expansion joints, sewer lines, or other openings that would permit liquids to flow from the curbed area;

(iv) Floors and curbing constructed of continuous smooth and impervious materials, such as Portland cement concrete or steel, to prevent or minimize penetration of PCBs; and

(v) Not located at a site that is below the 100-year flood water elevation.

(2) [Reserved]

(c)(1) The following PCB Items may be stored temporarily in an area that does not comply with the requirements of paragraph (b) of this section for up to thirty days from the date of their removal from service, provided that a notation is attached to the $\mathrm{PCB}$ Item or a PCB Container (containing the item) indicating the date the item was removed from service:

(i) Non-leaking PCB Articles and PCB Equipment;

(ii) Leaking PCB Articles and PCB Equipment if the PCB Items are placed in a non-leaking PCB Container that contains sufficient sorbent materials to absorb any liquid PCBs remaining in the PCB Items;

(iii) PCB Containers containing nonliquid PCBs such as contaminated soil, rags, and debris; and (iv) $\mathrm{PCB}$ Containers containing liquid PCBs at a concentration between 50 and 500 ppm, provided a Spill Prevention, Control and Countermeasure Plan has been prepared for the temporary storage area in accordance with 40 CFR Part 112. In addition, each container must bear a notation that indicates that the liquids in the drum do not exceed 500 ppm PCB.

(2) Non-leaking and structurally undamaged PCB Large High Voltage Capacitors and PCB-Contaminated Electrical Equipment that have not been drained of free flowing dielectric fluid may be stored on pallets next to a storage facility that meets the requirements of paragraph (b) of this section. PCB-Contaminated Electrical Equipment that has been drained of free flowing dielectric fluid is not subject to the storage provisions of $\$ 761.65$. Storage under this subparagraph will be permitted only when the storage facility has immediately available unfilled storage space equal to 10 percent of the volume of capacitors and equipment stored outside the facility. The capacitors and equipment temporarily stored outside the facility shall be checked for leaks weekly.

(3) Any storage area subject to the requirements of paragraph (b) or paragraph (c)(1) of this section shall be marked as required in Subpart C-\$761.40(a)(10).

(4) No item of movable equipment that is used for handling PCBs and PCB Items in the storage facilities and that comes in direct contact with PCBs shall be removed from the storage facility area unless it has been decontaminated as specified in $\$ 761.79$.

(5) All PCB Articles and PCB Containers in storage shall be checked for leaks at least once every 30 days. Any leaking PCB Articles and $\mathrm{PCB}$ Containers and their contents shall be transferred immediately to properly marked non-leaking containers. Any spilled or leaked materials shall be immediately cleaned up, using sorbents or other adequate means, and the PCB-contaminated materials and residues shall be disposed of in accordance with $\$ 761.60(a)(4)$.

(6) Except as provided in paragraph (c)(7) of this section, any container used for the storage of liquid PCBs shall comply with the Shipping Container Specification of the Department of Transportation (DOT), 49 CFR 178.80 (Specification 5 container without removable head), 178.82 (Specification 5B container without removable head), 
178.102 (Specification 6D overpack with Specification $2 S(\$ 178.35)$ or 2 SL $(\$ 178.35 a)$ polyethylene containers) or 178.116 (Specification 17E container). Any container used for the storage of non-liquid PCBs shall comply with the specifications of 49 CFR 178.80 (Specification 5 container), 178.82 (Specification 5B container) or 178.115 (Specification 17C container). As an alternate, containers larger than those specified in DOT Specifications $5,5 \mathrm{~B}$, or $17 \mathrm{C}$ may be used for non-liquid PCBs if the containers are designed and constructed in a manner that will provide as much protection against leaking and exposure to the environment as the DOT Specification containers, and are of the same relative strength and durability as the DOT Specification containers.

(7) Storage containers for liquid PCBs can be larger than the containers specified in paragraph (c)(6) of this section provided that:

(i) The containers are designed, constructed, and operated in compliance with Occupational Safety and Health Standards, 29 CFR 1910.106, Flammable and combustible liquids. Before using these containers for storing PCBs, the design of the containers must be reviewed to determine the effect on the structural safety of the containers that will result from placing liquids with the specific gravity of PCBs into the containers (see 29 CFR 1910.106(b)(1)(i)(f)).

(ii) The owners or operators of any facility using containers described in paragraph (c)(7)(i) of this section, shall prepare and implement a Spill Prevention Control and Countermeasure (SPCC) Plan as described in Part 112 of this title. In complying with 40 CFR Part 112, the owner or operator shall read "oil(s)" as "PCB(s)" whenever it appears. The exemptions for storage capacity, 40 CFR 112.1(d)(2), and the amendment of SPCC plans by the Regional Administrator, 40 CFR 112.4, shall not apply unless some fraction of the liquids stored in the container are oils as defined by section 311 of the Clean Water Act.

(8) PCB Articles and PCB Containers shall be dated on the article or container when they are placed in storage. The storage shall be managed so that the PCB Articles and PCB Containers can be located by the date they entered storage. Storage containers provided in paragraph (c)(7) of this section, shall have a record that includes for each batch of PCBs the quantity of the batch and date the batch was added to the container. The record shall also include the date, quantity, and disposition of any batch of PCBs removed from the container.

(9) Owners or operators of storage facilities shall establish and maintain records as provided in $\$ 761.180$.

(d) Approval of commercial storers of $P C B$ waste.

(1) All commercial storers of PCB waste shall have interim approval to operate commercial facilities for the storage of PCB waste until August 2, 1990. Commercial storers of PCB waste are prohibited from storing any PCB waste at their facilities after August 2, 1990 unless they have submitted by August 2, 1990 a complete application for a final storage approval under paragraph (d)(2) of this section. The period of interim approval shall continue until the Regional Administrator (or the Director of the Chemical Management Division (Director, CMD) in cases involving commercial storage ancillary to a facility approved for disposal by the Director, CMD) makes a final decision on the storage application at which time such interim approval shall terminate.

(2) The Regional Administrator for the region in which the storage facility is located (or the Director, CMD, if the commercial storage area is ancillary to a facility approved for disposal by the Director, CMD) shall grant written, final approval to engage in the commercial storage of $\mathrm{PCB}$ waste upon a determination by the Regional Administrator or the Director, CMD, that the criteria in paragraph (d)(2)(i) through (d)(2)(vii) of this section have been met by the applicant:

(i) The applicant, its principals, and its key employees responsible for the establishment or operation of the commercial storage facility are qualified to engage in the business of commercial storage of PCB waste.

(ii) The facility possesses the capacity to handle the quantity of PCB waste which the owner or operator of the facility has estimated will be the maximum quantity of PCB waste that will be handled at any one time at the facility.

(iii) The owner or operator of the facility has certified compliance with the storage facility standards in paragraphs (b) and (c)(7) of this section.

(iv) The owner or operator has developed a written closure plan for the facility that is deemed acceptable by the Regional Administrator (or the Director, CMD, if the 
commercial storage is ancillary to a disposal facility permitted by the Director, CMD) under the closure plan standards of paragraph (e) of this section.

(v) The owner or operator has included in the application for final approval a demonstration of financial responsibility for closure that meets the financial responsibility standards of paragraph (g) of this section.

(vi) The operation of the storage facility will not pose an unreasonable risk of injury to health or the environment.

Revised

58 FR 59374

November 9, 1993 (vii) The environmental compliance history of the applicant, its principals, and its key employees may be deemed to constitute a sufficient basis for denial of approval whenever in the judgment of the Regional Administrator (or Director, CMD) that history of environmental civil violations or criminal convictions evidence a pattern or practice of non compliance that demonstrates the applicant's unwillingness or inability to achieve and maintain compliance with the regulations.

(3) Applicants for storage approvals shall submit a written application that includes any relevant information bearing upon the qualifications of the facility's principals and key employees to engage in the business of commercial storage of PCB wastes. This information shall include, but is not limited to:

(i) The identification of the owner and the operator of the facility, including all general partners of a partnership, any limited partner of a partnership, any stockholder of a corporation or any participant in any other type of business organization or entity who owns or controls, directly or indirectly, more than 5 percent of each partnership, corporation, or other business organization and all officials of the facility who have direct management responsibility for the facility.

(ii) The identification of the person responsible for the overall operations of the facility (i.e., a plant manager, superintendent, or a person of similar responsibility) and the supervisory employees who are or will be responsible for the operation of the facility.

(iii) Information concerning the technical qualifications and experience of the persons responsible for the overall operation of the facility and the employees responsible for handling PCB waste or other wastes.

(iv) Information concerning any past State or Federal environmental violations involving the same business or another business with which the principals or supervisory employees were affiliated directly that occurred within 5 years preceding the date of submission and which relate directly to violations that resulted in either a civil penalty (irrespective of whether the matter was disposed of by an adjudication or by a without prejudice settlement) or judgment of conviction whether entered after trial or a plea, either of guilt or nolo contendere or civil injunctive relief and involved storage, disposal, transport, or other waste handling activities.

(v) A list of all companies currently owned or operated in the past by the principals or key employees identified in paragraphs (d)(3)(i) and (d)(3)(ii) of this section that are or were directly or indirectly involved with waste handling activities.

(vi) The owner's or operator's estimate of maximum PCB waste quantity to be handled at the facility.

(vii) A written statement certifying compliance with paragraph (b) or (c) of this section and containing a certification as defined in $\$ 761.3$.

(viii) A written closure plan for the facility, as described in paragraph (e) of this section.

(ix) The current closure cost estimate for the facility, as described in paragraph ( $f$ ) of this section.

(x) A demonstration of financial responsibility to close the facility, as described in paragraph $(\mathrm{g})$ of this section.

(4) The written approval issued by the Regional Administrator (or the Director, CMD, if the commercial storage area is ancillary to a disposal facility approved by the Director, CMD) shall include, but not be limited to, the following:

(i) The determination that the applicant has satisfied the requirements set forth in paragraph (d)(2) of this section, and a brief statement setting forth the basis for the determination.

(ii) Incorporation of the closure plan submitted by the facility owner or operator and approved by the Regional Administrator (or the Director, CMD, if the commercial storage area is ancillary to a disposal facility approved by the Director, CMD).

(iii) A condition imposing a maximum PCB storage capacity which the facility shall not exceed during its PCB waste storage operations. The maximum storage capacity imposed under this condition shall not be greater than the estimated maximum 
inventory of PCB waste included in the owner's or operator's application for final approval.

(iv) Such other conditions as deemed necessary by the Regional Administrator (or the Director, CMD, if the commercial storage area is ancillary to a disposal facility approved by the Director, CMD) to ensure that the operations of the PCB storage facility will not pose an unreasonable risk of injury to health or the environment.

(5) Storage areas at transfer facilities are exempt from the requirement to obtain approval as a commercial storer of PCB waste under this paragraph, unless the same PCB waste is stored at these facilities for a period of time greater than 10 consecutive days between destinations.

(6) Storage areas at RCRA-permitted facilities may be exempt from the separate TSCA storage approval requirements in this paragraph (d) upon a showing to the Regional Administrator's satisfaction that the facility's existing RCRA closure plan is substantially equivalent to this rule's closure plan standards, and that such facility's closure cost estimate and financial assurance demonstration account for maximum PCB waste inventories, and the requirements of paragraph (d)(3)(i) through (d)(3)(v) and (d)(3)(vii) of this section are met. A pay-in period of longer than 3 years after approval of the storage facility pursuant to this rule, will be acceptable to EPA if that pay-in period has already been established for a valid RCRA facility or previously approved TSCA facility.

(7) Storage areas ancillary to TSCA-approved disposal facilities may be exempt from a separate facility approval provided all of the following conditions are met:

(i) The current disposal approval contains an expiration date.

(ii) The current disposal approval's closure and financial responsibility conditions specifically extend to storage areas ancillary to disposal.

(iii) The current disposal approval's closure and financial responsibility conditions provide for annual adjustments for inflation, and for modification when changes in operation would affect closure costs.

(iv) The current disposal approval contains conditions on closure and financial responsibility that are at least as stringent as those in paragraphs (e) and (g) of this section.
However, the provision for a 3-year closure trust pay-in period, as specified in paragraph (g)(1)(i) of this section, would be waived in a case in which an approved TSCA facility or RCRA facility that covers PCB storage has a longer pay-in period for the trust.

(v) The current disposal approval satisfies the requirements of paragraph (d)(3)(i) through (d)(3)(v) of this section.

(8) The approval of any existing TSCA-approved disposal facility ancillary to a commercial storage facility that is deficient in any of the conditions of paragraph (d)(7)(i) through $(d)(7)(v)$ of this section shall be called in by the Regional Administrator or the Director, CMD, if it was the Director, CMD who issued it. The approval shall be modified to meet the requirements of paragraph (d)(7) of this section within 180 days of the effective date of this final rule, or a separate application for approval of the storage facility may be submitted to the Regional Administrator or the Director, CMD, in the cases where the Director, CMD issued the approval.

(e) Closure.

(1) A commercial storer of PCB waste shall have a written closure plan that identifies the steps that the owner or operator of the facility shall take to close the PCB waste storage facility in a manner that eliminates the potential for post-closure releases of PCBs which may present an unreasonable risk to human health or the environment. An acceptable closure plan must include, at a minimum, all of the following:

(i) A description of how the PCB storage areas of the facility will be closed in a manner that eliminates the potential for post-closure releases of PCBs into the environment.

(ii) An identification of the maximum extent of storage operations that will be open during the active life of the facility, including an identification of the extent of PCB storage operations at the facility relative to other wastes that will be handled at the facility.

(iii) An estimate of the maximum inventory of PCB wastes that could be handled at one time at the facility over its active life, and a detailed description of the methods or arrangements to be used during closure for removing, transporting, storing, or disposing of the facility's inventory of PCB waste, including an identification of any off-site facilities that will be used.

(iv) A detailed description of the steps needed to remove or decontaminate PCB 
waste residues and contaminated containment system components, equipment, structures, and soils during closure in accordance with the levels specified in the PCB Spills Cleanup Policy in subpart G of this part, including a description of the methods for sampling and testing of surrounding soils, and the criteria for determining the extent of removal or decontamination.

(v) A detailed description of other activities necessary during the closure period to ensure that any post-closure releases of PCBs will not present unreasonable risks to human health or the environment. This includes activities such as ground-water monitoring, run-on and run-off control, and facility security.

(vi) A schedule for closure of each area of the facility where PCB waste is stored or handled, including the total time required to close each area of PCB waste storage or handling, and the time required for any intervening closure activities.

(vii) An estimate of the expected year of closure of the PCB waste storage areas, if a trust fund is opted for as the financial mechanism.

(2) A written closure plan determined to be acceptable by the Regional Administrator (or the Director, CMD, if the commercial storage area is ancillary to a disposal facility approved by the Director, CMD) under this section shall become a condition of any approval granted under paragraph (d) of this section.

(3) A separate and new closure plan need not be submitted in cases where a facility is currently covered by a TSCA approval or a RCRA permit, upon a showing to the satisfaction of the Regional Administrator (or the Director, $\mathrm{CMD}$, if the commercial storage area is ancillary to a disposal facility approved by the Director, CMD) that the existing closure plan is substantially equivalent to closure plans required under paragraphs (d) through (g) of this section, and that the plan adequately accounts for PCB waste inventories.

(4) The commercial storer of PCB waste shall submit a written request to the Regional Administrator (or the Director, CMD, if he approved the closure plan) for a modification to its storage approval to amend its closure plan, whenever: (i) Changes in ownership, operating plans, or facility design affect the existing closure plan.

(ii) There is a change in the expected date of closure, if applicable.

(iii) In conducting closure activities, unexpected events require a modification of the approved closure plan.

(5) The Regional Administrator or the Director, CMD, if he approved the closure plan, may modify the existing closure plan under the conditions described in paragraph (e)(4) of this section.

(6) Commercial storers of PCB waste shall comply with the following closure schedule:

(i) The commercial storer shall notify in writing the Regional Administrator or the Director, CMD if he approved the closure plan, at least 60 days prior to the date on which final closure of its PCB storage facility is expected to begin.

(ii) The date when a commercial storer of PCB waste "expects to begin closure" shall be no later than 30 days after the date on which the storage facility received its final quantities of PCB waste. For good cause shown, the Regional Administrator or the Director, CMD if he approved the closure plan, may extend the date for commencement of closure for an additional 30-day period.

(iii) Within 90 days after receiving the final quantity of PCB waste for storage, a commercial storer of PCB waste shall remove all PCB waste in storage at the facility from the facility in accordance with the approved closure plan. For good cause shown, the Regional Administrator or the Director, CMD if he approved the closure plan, may approve a reasonable extension to the period for removal of the PCB waste.

(iv) A commercial storer of PCB waste shall complete closure activities in accordance with the approved closure plan and within 180 days after receiving the final quantity of PCB waste for storage at the facility. For good cause shown, the Regional Administrator or Director, CMD if he approved the closure plan, may approve a reasonable extension to the closure period.

(7) During the closure period, all contaminated system component equipment, structures, and soils shall be disposed of in accordance with the disposal requirements of subpart D of this part, or, if applicable, decontaminated in accordance with the levels specified in the PCB Spills Cleanup Policy at subpart $G$ of this part. When PCB waste is 
removed from the storage facility during closure, the owner or operator becomes a generator of PCB waste subject to the generator requirements of subpart $\mathrm{J}$ of this part.

(8) Within 60 days of completion of closure of each facility for the storage of PCB waste, the commercial storer of PCB waste shall submit to the Regional Administrator (or Director, CMD if he approved the closure plan), by registered mail, a certification that the PCB storage facility has been closed in accordance with the approved closure plan. The certification shall be signed by the owner or operator and by an independent registered professional engineer.

(f) Closure cost estimate.

(1) A commercial storer of PCB wastes shall have a detailed estimate, in current dollars, of the cost of closing the facility in accordance with its approved closure plan. The closure cost estimate shall be in writing, be certified by the person preparing it (using the certification defined in \$761.3) and comply with all of the following criteria:

(i) The closure cost estimate shall equal the cost of final closure at the point in the PCB storage facility's active life when the extent and manner of PCB storage operations would make closure the most expensive, as indicated by the facility's closure plan.

(ii) The closure cost estimate shall be based on the costs to the owner or operator of hiring a third party to close the facility, and the third party shall not be either a corporate parent or subsidiary of the owner or operator, or member in joint ownership of the facility.

(iii) The owner or operator shall include in the estimate the current market costs for off-site commercial disposal of the facility's maximum estimated inventory of PCB wastes, except that on-site disposal costs may be used if on-site disposal capacity will exist at the facility at all times over the life of the PCB storage facility.

(iv) The closure cost estimate may not incorporate any salvage value that may be realized with the sale of wastes, facility structures or equipment, land, or other assets associated with the facility at the time of closure.

(2) During the active life of the PCB storage facility, the commercial storer of PCB waste shall adjust annually for inflation the closure cost estimate within 60 days prior to the anniversary date of the establishment of the financial instruments used to demonstrate financial responsibility for closure, except that owners or operators who use the financial test or corporate guarantee shall adjust their closure cost estimates for inflation within 30 days after the close of the storer's fiscal year. The adjustment may be made by recalculating the maximum costs of closure in current dollars, or by using an inflation factor derived from the most recent Implicit Price Deflator for Gross National Product published by the U.S. Department of Commerce in its Survey of Current Business. The Implicit Price Deflator for Gross National Product is included in a monthly publication titled Economic Indicators, which is available from the Superintendent of Documents, Government Printing Office, Washington, DC 20402. The inflation factor used in the latter method is the result of dividing the latest published annual Deflator by the Deflator for the previous year. The adjustment to the closure cost estimate is then made by multiplying the most recent closure cost estimate by the latest inflation factor.

(3) Where the Regional Administrator (or the Director, CMD, if he approved the closure plan) approves a modification to the facility's closure plan, and that modification increases the cost of closure, the owner or operator shall revise the closure cost estimate no later than 30 days after the modification is approved. Any such revision shall also be adjusted for inflation in accordance with paragraph (f)(2) of this section.

(4) The owner or operator of the facility shall keep at the facility during its operating life the most recent closure cost estimate, including any adjustments resulting from inflation or from modifications to the closure plan.

(g) Financial assurance for closure. A commercial storer of PCB waste shall establish financial assurance for closure of each PCB storage facility that he owns or operates. In establishing financial assurance for closure, the commercial storer of PCB waste may choose from the following financial assurance mechanisms or any combination of mechanisms:

(1) The "closure trust fund," as specified in \$264.143(a) of this chapter, except for paragraph (a)(3) of $\$ 264.143$. For purposes of this paragraph, the following provisions also apply:

(i) Payments into the trust fund shall be made annually by the owner or operator over the remaining operating life of the facility as 
estimated in the closure plan, or over 3 years, whichever period is shorter. This period of time is hereafter referred to as the "pay-in period." For an existing facility, the first payment must be made within 30 calendar days after EPA has notified the facility of its conditional approval. Interim approval to operate is canceled and the application is denied if EPA does not receive verification that the payment was made in that 30 -day period.

(ii) For a new facility, the first payment into the closure trust fund shall be made before EPA grants final approval of the application and before the facility may accept the initial shipment of $\mathrm{PCB}$ waste for commercial storage. A receipt from the trustee shall be submitted by the owner or operator to the Regional Administrator (or the Director, CMD, if the commercial storage area is ancillary to a disposal facility approved by the Director EED) before this initial delivery of PCB waste. The first payment shall be at least equal to the current closure cost estimate, divided by the number of years in the pay-in period, except as provided in paragraph $(g)(7)$ of this section for multiple mechanisms. Subsequent payments shall be made no later than 30 days after each anniversary date of the first payment. The amount of each subsequent payment shall be determined by subtracting the current value of the trust fund from the current closure cost estimate, and dividing this difference by the number of years remaining in the pay-in period.

(iii) If an owner or operator of a facility existing on the effective date of this paragraph establishes a trust fund to meet the financial assurance requirements of this paragraph, and the value of the trust fund is less than the current closure cost estimate when a final approval is granted for the facility, the amount of the current closure cost estimate still to be paid into the trust fund shall be paid in over the pay-in period as defined in paragraph (g)(1)(i) of this section. Payments shall continue to be made no later than 30 days after each anniversary date of the first payment made into the trust fund. The amount of each payment shall be determined by subtracting the current value of the trust fund from the current closure cost estimate, and dividing this difference by the number of years remaining in the pay-in period.

(iv) The submission of a trust agreement with the wording specified in $\$ 264.151(\mathrm{a})(1)$ of this chapter, including any reference to hazardous waste management facilities, shall be deemed to be in compliance with the requirement to submit a trust agreement under this subpart.

(2) The "surety bond guaranteeing payment into a closure trust fund," as specified in \$264.143(b) of this chapter, including the use of the surety bond instrument specified at $\$ 264.151(b)$ of this chapter and the standby trust specified at $\$ 264.143(b)(3)$ of this chapter. The use of the surety bonds, surety bond instruments, and standby trust agreements specified in $\$ \$ 264.143(b)$ and 264.151(b) of this chapter shall be deemed to be in compliance with this subpart.

(3)(i) The "surety bond guaranteeing performance of closure," as specified at $\$ 264.143$ (c) of this chapter, except for paragraph (c)(5) of $\$ 264.143$ of this chapter. The submission and use of the surety bond instrument specified at $\$ 264.151$ (c) of this chapter and the standby trust specified at $\$ 264.143(\mathrm{c})(3)$ of this chapter shall be deemed to be in compliance with the requirements under this subpart relating to the use of surety bonds and standby trust funds.

(ii) For the purposes of this paragraph, and under the terms of the bond, the surety shall become liable on the bond obligation when the owner or operator fails to perform as guaranteed by the bond. Liability is established by a final administrative determination pursuant to section 16 of TSCA that the owner or operator has failed to perform final closure in accordance with the closure plan and other approval or regulatory requirements when required to do so.

(4)(i) The "closure letter of credit" specified in $\$ 264.143$ (d) of this chapter, except for paragraph (d)(8). The submission and use of the irrevocable letter of credit instrument specified in $\$ 264.151$ (d) of this chapter and the standby trust specified in $\$ 264.143(\mathrm{~d})(3)$ of this chapter shall be deemed to be in compliance with the requirements of this subpart relating to the use of letters of credit and standby trust funds.

(ii) For the purposes of this paragraph, the Regional Administrator (or the Director, CMD, if the commercial storage area is ancillary to a disposal facility approved by the Director, CMD) may draw on the letter of credit following a final administrative determination pursuant to section 16 of TSCA that the owner or operator has failed to 
perform final closure in accordance with the closure plan and other approval or regulatory requirements when required to do so.

(5) "Closure insurance," as specified in $\$ 264.143(\mathrm{e})$ of this chapter, utilizing the certificate of insurance for closure specified at $\$ 264.151$ (e) of this chapter. The use of closure insurance as specified in \$264.143(e) of this chapter and the submission and use of the certificate of insurance specified in $\$ 264.151$ (e) of this chapter shall be deemed to be in compliance with the requirements of this subpart relating to the use of closure insurance.

(6) The "financial test and corporate guarantee for closure," as described in $\$ 264.143(f)$ of this chapter, including a letter signed by the owner's or operator's chief financial officer as specified at $\$ 264.151(f)$ of this chapter and, if applicable, the written corporate guarantee specified at $\$ 264.151(\mathrm{~h})$ of this chapter. The use of the financial test and corporate guarantee specified in $\$ 264.143(\mathrm{f})$ of this chapter, the submission and use of the letter specified in $\$ 264.151(\mathrm{f})$ of this chapter, and the submission and use of the written corporate guarantee specified at $\$ 264.151(\mathrm{~h})$ of this chapter shall be deemed to be in compliance with the requirements of this subpart relating to the use of financial tests and corporate guarantees.

(7) The use of multiple financial mechanisms, as specified in $\$ 264.143(\mathrm{~g})$ of this chapter is permitted.

(h) Release of owner or operator. Within 60 days after receiving certifications from the owner or operator and an independent registered professional engineer that final closure has been completed in accordance with the approved closure plan, the Regional Administrator or the Director, CMD, if he approved the closure plan, will notify the owner or operator in writing that the owner or operator is no longer required by this section to maintain financial assurance for final closure of the facility, unless the Regional Administrator or the Director, CMD, if he approved the closure plan, has reason to believe that final closure has not been completed in accordance with the approved closure plan. The Regional Administrator or the Director, CMD, if he approved the closure plan, shall provide the owner or operator with a detailed written statement stating the reasons why he believed closure was not conducted in accordance with the approved closure plan. (i) Laboratories and samples.

(1) A laboratory is conditionally exempt from the notification and approval requirements for a commercial storer under $\$ 761.65$ (d) through (h) when it stores samples held for disposal in a facility that complies with the standards in $\$ 761.65$ (b)(1)(i) through (b)(1)(iv).

(2) A laboratory sample is exempt from the manifesting requirements in $\$ 761.208$ when:

(i) The sample is being transported to a laboratory for the purpose of testing.

(ii) The sample is being transported back to the sample collector after testing.

(iii) The sample is being stored by the sample collector before transport to a laboratory for testing.

(iv) The sample is being stored in a laboratory before testing.

(v) The sample is being stored in a laboratory after testing but before it is returned to the sample collector.

(vi) The sample is being stored temporarily in the laboratory after testing for a specific purpose (for example, until conclusion of a court case or enforcement action where further testing of the sample may be necessary).

(3) In order to qualify for the exemption in paragraph (i)(2)(i) and (i)(2)(ii) of this section, a sample collector shipping samples to a laboratory and a laboratory returning samples to a sample collector must:

(i) Comply with applicable U.S. Department of Transportation (DOT) or U.S. Postal Service (USPS) shipping requirements, found respectively in $49 \mathrm{CFR}$ 173.345 and U.S. Postal Regulations 652.2 and 652.3.

(ii) Assure that the following information accompanies the sample:

(A) The sample collector's name, mailing address, and telephone number.

(B) The laboratory's name, mailing address, and telephone number.

(C) The quantity of the sample.

(D) The date of shipment.

(E) A description of the sample.

(iii) Package the sample so that it does not leak, spill, or vaporize from its packaging.

(4) When the concentration of the PCB sample has been determined, and its use is terminated, the sample must be properly disposed. A laboratory must either manifest the PCB waste to a disposer or commercial storer, as required under $\$ 761.208$, retain a copy of each manifest, as required under 
$\$ 761.209$, and follow up on exception reporting, as required under $\$ 761.215$ (a) and (b), or return the sample to the sample collector who must then properly dispose of the sample. If the laboratory returns the sample to the sample collector, the laboratory must comply with the shipping requirements set forth in paragraph (i)(3)(i) through (i)(3)(iii) of this section.

(j) States and the Federal Government. States and the Federal Government are exempt from the requirements of paragraphs (f) and (g) of this section.

(Sec. 6, Pub. L. 94-469, 90 Stat. 2020 (15 U.S.C. 2605)

[44 FR 31542, May 31, 1979. Redesignated at 47 FR 19527, May 6, 1982, and amended at 47 FR 37359, Aug. 8, 1982; 49 FR 28191, July 10, 1984; 53 FR 12524, Apr. 15, 1988; 54 FR 52746, Dec. 21, 1989; 55 FR 695, Jan. 8, 1990; 55 FR 26205, June 27, 1990; 58 FR 15809, Mar. 24, 1993; 58 FR 34205, June 23, 1993; 58 FR 59374, Nov. 9, 1993]

\section{$\$ 761.70$ Incineration.}

This section applies to facilities used to incinerate $\mathrm{PCB}$ s required to be incinerated by this part.

(a) Liquid PCBs. An incinerator used for incinerating PCBs shall be approved by an EPA Regional Administrator or the Director, Chemical Management Division pursuant to paragraph (d) of this section. Requests for approval of incinerators to be used in more than one region must be submitted to the Director, Chemical Management Division, except for research and development involving less than 500 pounds of $\mathrm{PCB}$ material (see $\$ 761.60(i)(2)$ ). Requests for approval of incinerators to be used in only one region must be submitted to the appropriate Regional Administrator. The incinerator shall meet all of the requirements specified in paragraphs (a) (1) through (9) of this section, unless a waiver from these requirements is obtained pursuant to paragraph (d)(5) of this section. In addition, the incinerator shall meet any other requirements which may be prescribed pursuant to paragraph (d)(4) of this section.

(1) Combustion criteria shall be either of the following:

(i) Maintenance of the introduced liquids for a 2-second dwell time at $1200^{\circ} \mathrm{C}\left(+/-100^{\circ} \mathrm{C}\right)$ and 3 percent excess oxygen in the stack gas; or

(ii) Maintenance of the introduced liquids for a $1 \quad 1 / 2$ second dwell time at $1600^{\circ} \mathrm{C}\left(+100^{\circ} \mathrm{C}\right)$ and 2 percent excess oxygen in the stack gas.
(2) Combustion efficiency shall be at least 99.9 percent computed as follows:

\section{Combustion efficiency $=$ $\left[\mathrm{C}_{\mathrm{CO} 2} /\left(\mathrm{C}_{\mathrm{CO} 2}+\mathrm{C}_{\mathrm{CO}}\right)\right] 100$ \\ where}

$\mathrm{CCO}_{2}=$ Concentration of carbon dioxide.

$\mathrm{CcO}=$ Concentration of carbon monoxide.

(3) The rate and quantity of PCBs which are fed to the combustion system shall be measured and recorded at regular intervals of no longer than 15 minutes.

(4) The temperatures of the incineration process shall be continuously measured and recorded. The combustion temperature of the incineration process shall be based on either direct (pyrometer) or indirect (wall thermocouple-pyrometer correlation) temperature readings.

(5) The flow of PCBs to the incinerator shall stop automatically whenever the combustion temperature drops below the temperatures specified in paragraph (a)(1) of this section.

(6) Monitoring of stack emission products shall be conducted:

(i) When an incinerator is first used for the disposal of PCBs under the provisions of this regulation;

(ii) When an incinerator is first used for the disposal of PCBs after the incinerator has been modified in a manner which may affect the characteristics of the stack emission products; and

(iii) At a minimum such monitoring shall be conducted for the following parameters:

(a) $\mathrm{O}_{2}$; (b) $\mathrm{CO}$; (c) $\mathrm{Co}_{2}$; (d) Oxides of Nitrogen $\left(\mathrm{NO}_{\mathbf{x}}\right)$; (e) Hydrochloric Acid (HCl); (f) Total Chlorinated Organic Content (RCl); (g) PCBs; and (h) Total Particulate Matter.

(7) At a minimum monitoring and recording of combustion products and incineration operations shall be conducted for the following parameters whenever the incinerator is incinerating PCBs:

(i) $\mathrm{O}_{2}$; (ii) $\mathrm{CO}$; and (iii) $\mathrm{Co}_{2}$. The monitoring for $\mathrm{O}_{2}$ and $\mathrm{CO}$ shall be continuous. The monitoring for $\mathrm{Co}_{2}$ shall be periodic, at a frequency specified by the Regional Administrator or Director, Chemical Managment Division.

(8) The flow of PCBs to the incinerator shall stop automatically when any one or more of the following conditions occur, unless a contingency plan is submitted by the incinerator owner or operator and approved 
by the Regional Administrator or Director, Chemical Management Division. The contingency plan indicates what alternative measures the incinerator owner or operator would take if any of the following conditions occur:

(i) Failure of monitoring operations specified in paragraph (a)(7) of this section;

(ii) Failure of the PCB rate and quantity measuring and recording equipment specified in paragraph (a)(3) of this section; or

(iii) Excess oxygen falls below the percentage specified in paragraph (a)(1) of this section.

(9) Water scrubbers shall be used for $\mathrm{HCl}$ control during PCB incineration and shall meet any performance requirements specified by the appropriate EPA Regional Administrator or the Director, Chemical Management Division. Scrubber effluent shall be monitored and shall comply with applicable effluent or pretreatment standards, and any other State and Federal laws and regulations. An alternate method of $\mathrm{HCl}$ control may be used if the alternate method has been approved by the Regional Administrator or the Director, Chemical Management Division. (The $\mathrm{HCl}$ neutralizing capability of cement kilns is considered to be an alternate method.)

(b) Nonliquid PCBs. An incinerator used for incinerating nonliquid PCBs, PCB Articles, PCB Equipment, or PCB Containers shall be approved by the appropriate EPA Regional Administrator or the Director, Chemical Management Division pursuant to paragraph (d) of this section. Requests for approval of incinerators to be used in more than one region must be submitted to the Director, Chemical Management Division, except for research and development involving less than 500 pounds of PCB material (see $\$ 761.60(i)(2)$ ). Requests for approval of incinerators to be used in only one region must be submitted to the appropriate Regional Administrator. The incinerator shall meet all of the requirements specified in paragraphs (b)(1) and (2) of this section unless a waiver from these requirements is obtained pursuant to paragraph (d)(5) of this section. In addition, the incinerator shall meet any other requirements that may be prescribed pursuant to paragraph (d)(4) of this section.

(1) The mass air emissions from the incinerator shall be no greater than $0.001 \mathrm{~g}$
$\mathrm{PCB} / \mathrm{kg}$ of the PCB introduced into the incinerator.

(2) The incinerator shall comply with the provisions of paragraphs (a)(2), (3), (4), (6), (7), (8)(i) and (ii), and (9) of this section.

(c) Maintenance of data and records. All data and records required by this section shall be maintained in accordance with $\$ 761.180$, Records and monitoring.

(d) Approval of incinerators. Prior to the incineration of PCBs and PCB Items the owner or operator of an incinerator shall receive the written approval of the Agency Regional Administrator for the region in which the incinerator is located, or the Director, Chemical Management Division. Approval from the Director, Chemical Management Division may be effective in all ten EPA regions. Such approval shall be obtained in the following manner:

(1) Application. The owner or operator shall submit to the Regional Administrator or the Director, Chemical Management Division an application which contains:

(i) The location of the incinerator;

(ii) A detailed description of the incinerator including general site plans and design drawings of the incinerator;

(iii) Engineering reports or other information on the anticipated performance of the incinerator;

(iv) Sampling and monitoring equipment and facilities available;

(v) Waste volumes expected to be incinerated;

(vi) Any local, State, or Federal permits or approvals; and

(vii) Schedules and plans for complying with the approval requirements of this regulation.

(2) Trial burn.

(i) Following receipt of the application described in paragraph (d)(1) of this section, the Regional Administrator or the Director, Chemical Management Division shall determine if a trial burn is required and notify the person who submitted the report whether a trial burn of PCBs and PCB Items must be conducted. The Regional Administrator or the Director, Chemical Management Division may require the submission of any other information that the Regional Administrator or the Director, Chemical Management Division finds to be reasonably necessary to determine the need for a trial burn. Such other information shall be restricted to the types of 
information required in paragraphs $(d)(1)(i)$ through (vii) of this section.

(ii) If the Regional Administrator or the Director, Chemical Management Division determines that a trial burn must be held, the person who submitted the report described in paragraph (d)(1) of this section shall submit to the Regional Administrator or the Director, Chemical Management Division a detailed plan for conducting and monitoring the trial burn. At a minimum, the plan must include:

(A) Date trial burn is to be conducted;

(B) Quantity and type of PCBs and PCB Items to be incinerated;

(C) Parameters to be monitored and location of sampling points;

(D) Sampling frequency and methods and schedules for sample analyses; and

(E) Name, address, and qualifications of persons who will review analytical results and other pertinent data, and who will perform a technical evaluation of the effectiveness of the trial burn.

(iii) Following receipt of the plan described in paragraph (d)(2)(ii) of this section, the Regional Administrator or the Director, Chemical Management Division will approve the plan, require additions or modifications to the plan, or disapprove the plan. If the plan is disapproved, the Regional Administrator or the Director, Chemical Management Division will notify the person who submitted the plan of such disapproval, together with the reasons why it is disapproved. That person may thereafter submit a new plan in accordance with paragraph (d)(2)(ii) of this section. If the plan is approved (with any additions or modifications which the Regional Administrator or the Director, Chemical Management Division may prescribe), the Regional Administrator or the Director, Chemical Management Division will notify the person who submitted the plan of the approval. Thereafter, the trial burn shall take place at a date and time to be agreed upon between the Regional Administrator or the Director, Chemical Management Division and the person who submitted the plan.

(3) Other information. In addition to the information contained in the report and plan described in paragraphs (d)(1) and (2) of this section, the Regional Administrator or the Assistant Administrator for Pesticides and Toxic Substances may require the owner or operator to submit any other information that the Regional Administrator or the Assistant
Administrator for Pesticides and Toxic Substances finds to be reasonably necessary to determine whether an incinerator shall be approved.

Note: The Regional Administrator will have available for review and inspection an Agency manual containing information on sampling methods and analytical procedures for the parameters required in $\$ 761.70(a)(3),(4),(6)$, and (7) plus any other parameters he/she may determine to be appropriate. Owners or operators are encouraged to review this manual prior to submitting any report required in $\$ 761.70$.

(4) Contents of approval.

(i) Except as provided in paragraph (d)(5) of this section, the Regional Administrator or the Director, Chemical Management Division may not approve an incinerator for the disposal of PCBs and PCB Items unless he finds that the incinerator meets all of the requirements of paragraphs (a) and/or (b) of this section.

(ii) In addition to the requirements of paragraphs (a) and/or (b) of this section, the Regional Administrator or the Director, Chemical Management Division may include in an approval any other requirements that the Regional Administrator or the Director, Chemical Management Division finds are necessary to ensure that operation of the incinerator does not present an unreasonable risk of injury to health or the environment from PCBs. Such requirements may include a fixed period of time for which the approval is valid.

(5) Waivers. An owner or operator of the incinerator may submit evidence to the Regional Administrator or the Director, Chemical Management Division that operation of the incinerator will not present an unreasonable risk of injury to health or the environment from PCBs, when one or more of the requirements of paragraphs (a) and/or (b) of this section are not met. On the basis of such evidence and any other available information, the Regional Administrator or the Director, Chemical Management Division may in his/her discretion find that any requirement of paragraphs (a) and (b) of this section is not necessary to protect against such a risk, and may waive the requirements in any approval for that incinerator. Any finding and waiver under this paragraph must be stated in writing and included as part of the approval.

(6) Persons approved. An approval will designate the persons who own and who are authorized to operate the incinerator, and will apply only to such persons, except as provided in paragraph (d)(8) of this section. 
(7) Final approval. Approval of an incinerator will be in writing and signed by the Regional Administrator or the Director, Chemical Management Division. The approval will state all requirements applicable to the approved incinerator.

(8) Transfer of property. Any person who owns or operates an approved incinerator must notify EPA at least 30 days before transferring ownership in the incinerator or the property it stands upon, or transferring the right to operate the incinerator. The transferor must also submit to EPA, at least 30 days before such transfer, a notarized affidavit signed by the transferee which states that the transferee will abide by the transferor's EPA incinerator approval. Within 30 days of receiving such notification and affidavit, EPA will issue an amended approval substituting the transferee's name for the transferor's name, or EPA may require the transferee to apply for a new incinerator approval. In the latter case, the transferee must abide by the transferor's EPA approval until EPA issues the new approval to the transferee.

(Sec. 6, Pub. L. 94-469, 90 Stat. 2020 (15 U.S.C. 2605)

[44 FR 31542, May 31, 1979. Redesignated at 47 FR 19527, May 6, 1982, and amended at 48 FR 13185, Mar. 30,$1983 ; 49$ FR 28191, July 10, 1984; 53 FR 12524, Apr. 15, 1988; 58 FR 15809, Mar. 24, 1993]

\section{\$761.75 Chemical waste landfills.}

This section applies to facilities used to dispose of PCBs in accordance with the part.

(a) General. A chemical waste landfill used for the disposal of PCBs and PCB Items shall be approved by the Agency Regional Administrator pursuant to paragraph (c) of this section. The landfill shall meet all of the requirements specified in paragraph (b) of this section, unless a waiver from these requirements is obtained pursuant to paragraph (c)(4) of this section. In addition, the landfill shall meet any other requirements that may be prescribed pursuant to paragraph (c)(3) of this section.

(b) Technical requirements. Requirements for chemical waste landfills used for the disposal of PCBs and PCB Items are as follows:

(1) Soils. The landfill site shall be located in thick, relatively impermeable formations such as large-area clay pans. Where this is not possible, the soil shall have a high clay and silt content with the following parameters:

(i) In-place soil thickness, 4 feet or compacted soil liner thickness, 3 feet; (ii) Permeability $(\mathrm{cm} / \mathrm{sec})$, equal to or less than $1 \times 10^{-7}$;

(iii) Percent soil passing No. 200 Sieve, 30;

(iv) Liquid Limit, 30; and

(v) Plasticity Index 15.

(2) Synthetic membrane liners. Synthetic membrane liners shall be used when, in the judgment of the Regional Administrator, the hydrologic or geologic conditions at the landfill require such a liner in order to provide at least a permeability equivalent to the soils in paragraph (b)(1) of this section. Whenever a synthetic liner is used at a landfill site, special precautions shall be taken to insure that its integrity is maintained and that it is chemically compatible with PCBs. Adequate soil underlining and soil cover shall be provided to prevent excessive stress on the liner and to prevent rupture of the liner. The liner must have a minimum thickness of 30 mils.

(3) Hydrologic conditions. The bottom of the landfill shall be above the historical high groundwater table as provided below. Floodplains, shorelands, and groundwater recharge areas shall be avoided. There shall be no hydraulic connection between the site and standing or flowing surface water. The site shall have monitoring wells and leachate collection. The bottom of the landfill liner system or natural in-place soil barrier shall be at least fifty feet from the historical high water table.

(4) Flood protection.

(i) If the landfill site is below the 100-year floodwater elevation, the operator shall provide surface water diversion dikes around the perimeter of the landfill site with a minimum height equal to two feet above the 100-year floodwater elevation.

(ii) If the landfill site is above the 100-year floodwater elevation, the operators shall provide diversion structures capable of diverting all of the surface water runoff from a 24-hour, 25-year storm.

(5) Topography. The landfill site shall be located in an area of low to moderate relief to minimize erosion and to help prevent landslides or slumping.

(6) Monitoring systems-

(i) Water sampling. (A) For all sites receiving PCBs, the ground and surface water from the disposal site area shall be sampled prior to commencing operations under an approval provided in paragraph (c) of this section for use as baseline data. 
(B) Any surface watercourse designated by the Regional Administrator using the authority provided in paragraph (c)(3)(ii) of this section shall be sampled at least monthly when the landfill is being used for disposal operations.

(C) Any surface watercourse designated by the Regional Administrator using the authority provided in paragraph (c)(3)(ii) of this section shall be sampled for a time period specified by the Regional Administrator on a frequency of no less than once every six months after final closure of the disposal area.

(ii) Groundwater monitor wells.

(A) If underlying earth materials are homogenous, impermeable, and uniformly sloping in one direction, only three sampling points shall be necessary. These three points shall be equally spaced on a line through the center of the disposal area and extending from the area of highest water table elevation to the area of the lowest water table elevation on the property.

(B) All monitor wells shall be cased and the annular space between the monitor zone (zone of saturation) and the surface shall be completely backfilled with Portland cement or an equivalent material and plugged with Portland cement to effectively prevent percolation of surface water into the well bore. The well opening at the surface shall have a removable cap to provide access and to prevent entrance of rainfall or stormwater runoff. The well shall be pumped to remove the volume of liquid initially contained in the well before obtaining a sample for analysis. The discharge shall be treated to meet applicable State or Federal discharge standards or recycled to the chemical waste landfill.

(iii) Water analysis. As a minimum, all samples shall be analyzed for the following parameters, and all data and records of the sampling and analysis shall be maintained as required in $\$ 761.180(d)(1)$. Sampling methods and analytical procedures for these parameters shall comply with those specified in 40 CFR Part 136 as amended in 41 FR 52779 on December 1, 1976.

(A) PCBs.

(B) $\mathrm{pH}$.

(C) Specific conductance.

(D) Chlorinated organics.

(7) Leachate collection. A leachate collection monitoring system shall be installed above the chemical waste landfill. Leachate collection systems shall be monitored monthly for quantity and physicochemical characteristics of leachate produced. The leachate should be either treated to acceptable limits for discharge in accordance with a State or Federal permit or disposed of by another State or Federally approved method. Water analysis shall be conducted as provided in paragraph (b)(6)(iii) of this section. Acceptable leachate monitoring/collection systems shall be any of the following designs, unless a waiver is obtained pursuant to paragraph (c)(4) of this section.

(i) Simple leachate collection. This system consists of a gravity flow drainfield installed above the waste disposal facility liner. This design is recommended for use when semi-solid or leachable solid wastes are placed in a lined pit excavated into a relatively thick, unsaturated, homogenous layer of low permeability soil.

(ii) Compound leachate collection. This system consists of a gravity flow drainfield installed above the waste disposal facility liner and above a secondary installed liner. This design is recommended for use when semi-liquid or leachable solid wastes are placed in a lined pit excavated into relatively permeable soil.

(iii) Suction lysimeters. This system consists of a network of porous ceramic cups connected by hoses/tubing to a vacuum pump. The porous ceramic cups or suction lysimeters are installed along the sides and under the bottom of the waste disposal facility liner. This type of system works best when installed in a relatively permeable unsaturated soil immediately adjacent to the bottom and/or sides of the disposal facility.

(8) Chemical waste landfill operations.

(i) PCBs and PCB Items shall be placed in a landfill in a manner that will prevent damage to containers or articles. Other wastes placed in the landfill that are not chemically compatible with PCBs and PCB Items including organic solvents shall be segregated from the PCBs throughout the waste handling and disposal process.

(ii) An operation plan shall be developed and submitted to the Regional Administrator for approval as required in paragraph (c) of this section. This plan shall include detailed explanations of the procedures to be used for recordkeeping, surface water handling procedures, excavation and backfilling, waste segregation burial coordinates, vehicle and equipment movement, use of roadways, 
leachate collection systems, sampling and monitoring procedures, monitoring wells, environmental emergency contingency plans, and security measures to protect against vandalism and unauthorized waste placements. EPA guidelines entitled "Thermal Processing and Land Disposal of Solid Waste" (39 FR 29337, Aug. 14, 1974) are a useful reference in preparation of this plan. If the facility is to be used to dispose of liquid wastes containing between $50 \mathrm{ppm}$ and $500 \mathrm{ppm}$ PCB, the operations plan must include procedures to determine that liquid PCBs to be disposed of at the landfill do not exceed $500 \mathrm{ppm}$ PCB and measures to prevent the migration of $\mathrm{PCBs}$ from the landfill. Bulk liquids not exceeding $500 \mathrm{ppm}$ PCBs may be disposed of provided such waste is pretreated and/or stabilized (e.g., chemically fixed, evaporated, mixed with dry inert absorbent) to reduce its liquid content or increase its solid content so that a non-flowing consistency is achieved to eliminate the presence of free liquids prior to final disposal in a landfill. PCB Container of liquid PCBs with a concentration between 50 and $500 \mathrm{ppm}$ PCB may be disposed of if each container is surrounded by an amount of inert sorbent material capable of absorbing all of the liquid contents of the container.

(iii) Ignitable wastes shall not be disposed of in chemical waste landfills. Liquid ignitable wastes are wastes that have a flash point less than 60 degrees $C$ ( 140 degrees $F$ ) as determined by the following method or an equivalent method: Flash point of liquids shall be determined by a Pensky-Martens Closed Cup Tester, using the protocol specified in ASTM D 93-90, or the Setaflash Closed Tester using the protocol specified in ASTM Standard D-3278-89.

(iv) Records shall be maintained for all PCB disposal operations and shall include information on the PCB concentration in liquid wastes and the three dimensional burial coordinates for PCBs and PCB Items. Additional records shall be developed and maintained as required in $\$ 761.180$.

(9) Supporting facilities.

(i) A six foot woven mesh fence, wall, or similar device shall be placed around the site to prevent unauthorized persons and animals from entering.

(ii) Roads shall be maintained to and within the site which are adequate to support the operation and maintenance of the site without causing safety or nuisance problems or hazardous conditions.

(iii) The site shall be operated and maintained in a manner to prevent safety problems or hazardous conditions resulting from spilled liquids and windblown materials.

(c) Approval of chemical waste landfills. Prior to the disposal of any PCBs and PCB Items in a chemical waste landfill, the owner or operator of the landfill shall receive written approval of the Agency Regional Administrator for the Region in which the landfill is located. The approval shall be obtained in the following manner:

(1) Initial report. The owner or operator shall submit to the Regional Administrator an initial report which contains:

(i) The location of the landfill;

(ii) A detailed description of the landfill including general site plans and design drawings;

(iii) An engineering report describing the manner is which the landfill complies with the requirements for chemical waste landfills specified in paragraph (b) of this section;

(iv) Sampling and monitoring equipment and facilities available;

(v) Expected waste volumes of PCBs;

(vi) General description of waste materials other than PCBs that are expected to be disposed of in the landfill;

(vii) Landfill operations plan as required in paragraph (b) of this section;

(viii) Any local, State, or Federal permits or approvals; and

(ix) Any schedules or plans for complying with the approval requirements of these regulations.

(2) Other information. In addition to the information contained in the report described in paragraph (c)(1) of this section, the Regional Administrator may require the owner or operator to submit any other information that the Regional Administrator finds to be reasonably necessary to determine whether a chemical waste landfill should be approved. Such other information shall be restricted to the types of information required in paragraphs (c)(1) (i) through (ix) of this section.

(3) Contents of approval.

(i) Except as provided in paragraph (c)(4) of this section the Regional Administrator may not approve a chemical waste landfill for the disposal of PCBs and PCB Items, unless 
he finds that the landfill meets all of the requirements of paragraph (b) of this section.

(ii) In addition to the requirements of paragraph (b) of this section, the Regional Administrator may include in an approval any other requirements or provisions that the Regional Administrator finds are necessary to ensure that operation of the chemical waste landfill does not present an unreasonable risk of injury to health or the environment from PCBs. Such provisions may include a fixed period of time for which the approval is valid.

The approval may also include a stipulation that the operator of the chemical waste landfill report to the Regional Administrator any instance when PCBs are detectable during monitoring activities conducted pursuant to paragraph (b)(6) of this section.

(4) Waivers. An owner or operator of a chemical waste landfill may submit evidence to the Regional Administrator that operation of the landfill will not present an unreasonable risk of injury to health or the environment from PCBs when one or more of the requirements of paragraph (b) of this section are not met. On the basis of such evidence and any other available information, the Regional Administrator may in his discretion find that one or more of the requirements of paragraph (b) of this section is not necessary to protect against such a risk and may waive the requirements in any approval for that landfill. Any finding and waiver under this paragraph will be stated in writing and included as part of the approval.

(5) Persons approved. Any approval will designate the persons who own and who are authorized to operate the chemical waste landfill, and will apply only to such persons, except as provided by paragraph (c)(7) of this section.

(6) Final approval. Approval of a chemical waste landfill will be in writing and will be signed by the Regional Administrator. The approval will state all requirements applicable to the approved landfill.

(7) Transfer of property. Any person who owns or operates an approved chemical waste landfill must notify EPA at least 30 days before transferring ownership in the property or transferring the right to "conduct the chemical waste landfill operation. The transferor must also submit to EPA, at least 30 days before such transfer, a notarized affidavit signed by the transferee which states that the transferee will abide by the transferor's EPA chemical waste landfill approval. Within 30 days of receiving such notification and affidavit, EPA will issue an amended approval substituting the transferee's name for the transferor's name, or EPA may require the transferee to apply for a new chemical waste landfill approval. In the latter case, the transferee must abide by the transferor's EPA approval until EPA issues the new approval to the transferee.

(Sec. 6, Pub. L. 94-469, 90 Stat. 2020 (15 U.S.C. 2605)

[44 FR 31542, May 31, 1979. Redesignated at 47 FR 19527, May 6, 1982, and amended at 48 FR 5730, Feb. 8, 1983; 49 FR 28191, July 10, 1984; 53 FR 12524, Apr. 15, 1988; 53 FR 21641, June 9, 1988; 57 FR 13323, Apr. $16,1992]$

\section{\$761.79 Decontamination.}

(a) Any PCB Container to be decontaminated shall be decontaminated by flushing the internal surfaces of the container three times with a solvent containing less than $50 \mathrm{ppm}$ PCB. The solubility of PCBs in the solvent must be five percent or more by weight. Each rinse shall use a volume of the normal diluent equal to approximately ten (10) percent of the PCB Container capacity. The solvent may be reused for decontamination until it contains $50 \mathrm{ppm}$ PCB. The solvent shall then be disposed of as a PCB in accordance with $\$ 761.60(a)$. Non-liquid PCBs resulting from the decontamination procedures shall be disposed of in accordance with the provisions of $\$ 761.60(\mathrm{a})(4)$.

(b) Movable equipment used in storage areas shall be decontaminated by swabbing surfaces that have contacted PCBs with a solvent meeting the criteria of paragraph (a) of this section.

Note: Precautionary measures should be taken to ensure that the solvent meets safety and health standards as required by applicable Federal regulations.

[44 FR 31542, May 31, 1979. Redesignated at 47 FR 19527, May 6, 1982]

\section{Subpart E-Exemptions}

$\$ 761.80$ Manufacturing, processing, and distribution in commerce exemptions.

(a) The Administrator grants the following petitioner(s) an exemption for 1 year to process and distribute in commerce PCBs for use as a mounting medium in microscopy:

(1) McCrone Accessories Components, Division of Walter C. McCrone Associates, Inc., 2820 South Michigan Avenue, Chicago, IL. 60616 . 
(2) [Reserved]

(b) The Administrator grants the following petitioner(s) an exemption for 1 year to process and distribute in commerce PCBs for use as a mounting medium in microscopy, an immersion oil in low fluorescence microscopy and an optical liquid:

(1) R.P. Cargille Laboratories, Inc., 55 Commerce Road, Cedar Grove, N.J. 07009.

(2) [Reserved]

(c) The Administrator grants the following petitioner(s) an exemption for 1 year to export PCBs for use in small quantities for research and development:

(1) Accu-Standard, New Haven, CT. 06503.

Added

59 FR 16998

April 11, 1994

(2) ManTech, Research Triangle park, NC 27709. (d) The Administrator grants the following petitioner(s) an exemption for 1 year to import (manufacture) into the United States, small quantities of existing PCB fluids from electrical equipment for analysis:

(1) Unison Transformer Services, Inc., Tarrytown, N.Y. 10591, provided each of the following conditions are met:

(i) The samples must be shipped in $5.0 \mathrm{ml}$ or less, hermetically sealed vials.

(ii) The exemption is limited to no more than 250 total samples per year.

(iii) Unison makes quarterly inspections of its laboratories to ensure that proper safety procedures are being followed.

(iv) Unison annually notifies and describes to EPA its attempts to have samples analyzed abroad.

(2) [Reserved]

(e) [Reserved]

(f) The Administrator grants the following petitioner(s) an exemption for 1 year to manufacture PCBs for use in small quantities for research and development:

(1) California Bionuclear Corp., Sun Valley, CA 91352 (ME-13).

(2) Foxboro Co., North Haven, CT 06473 (ME-6).

(3) ULTRA-Scientific, Inc.,Hope, RI 02831 (ME-99.1).

(4) Midwest Research Institute, Kansas City, MO 64110 (ME-70.1).

(5) Pathfinder Laboratories, St. Louis, MO 63146 (A division of Sigma Aldridge Corporation, St. Louis, MO, 63178 (ME-76).

(6) Radian Corp., Austin, TX 78766 (ME-81.2).

(7) Wellington Sciences USA, College Station, TX 77840 (ME-104.1).
(8) Accu-Standard, 25 Science Park, New Haven, CT. 06503.

(g) The Administrator grants a class exemption to all processors and distributors of PCBs in small quantities for research and development provided that the following conditions are met:

(1) All processors and distributors must maintain records of their PCB activities for a period of 5 years.

(2) Any person or company which expects to process or distribute in commerce 100 grams $(.22 \mathrm{lb})$ or more PCBs in 1 year must report to EPA identifying the sites of PCB activities and the quantity of $\mathrm{PCBs}$ to be processed or distributed in commerce.

(h) The Administrator grants the following petitioners an exemption for 1 year to process and distribute in commerce PCBs for analytical reference samples derived from actual waste materials:

(1) R.T. Corporation, Laramie, WY 82070 .

(2) [Reserved]

(i)-(l) [Reserved]

(m) The Administrator grants the following petitioner(s) an exemption for 1 year to process and export small quantities of PCBs for research and development:

(1) Chem Service, Inc., West Chester, PA 19380 (PDE-41).

(2) Foxboro Co., North Haven, CT 06473 (ME-6).

(3) PolyScience Corp., Niles, IL 60648 (PDE-178).

(4) ULTRA-Scientific, Inc., Hope, RI 02831 (PDE-282.1).

(5) Supelco, Inc., Bellefonte, PA 16823-0048 (PDE-41.2).

(6) Radian Corp., Austin, TX 78766 (PDE-182.1).

(7) Restek Corporation, Bellefonte, PA 16823.

(n) The 1-year exemption granted to petitioners in paragraphs (a) through (c)(1), (d), (f), and (m)(1) through $(\mathrm{m})(6)$ of this section shall be renewed automatically as long as there is no increase in the amount PCBs to be processed and distributed, imported (manufactured), or exported, nor any change in the manner of processing and distributing, importing (manufacturing), or exporting of PCBs. If there is such a change, a new exemption petition must be submitted to EPA and it will be addressed through an exemption rulemaking. In such a case, the activities granted under the existing
Revised 59 FR 16998

April 11, 1994
Added

59 FR 16998

April 11, 1994

Revised

59 FR 16998

April 11, 1994 
exemption may continue until the new petition is addressed by rulemaking, but must conform to the terms of the existing exemption approved by EPA. The 1-year exemption granted to petitioners in paragraphs (c)(2), (h) and $) \mathrm{m})(7)$ of this section may be extended pursuant to $40 \mathrm{CFR}$ 750.11(e) of 750.31(e).

(o) The 1-year class exemption granted to all processors and distributors of PCBs in small quantities for research and development in paragraph $(\mathrm{g})$ of this section shall be renewed automatically unless information is submitted affecting EPA's conclusion that the class exemption, or the activities of any individual or company included in the exemption, will not pose an unreasonable risk of injury to health or the environment. EPA will evaluate the information, issue a proposed rule for public comment, and issue a final rule affecting the class exemption or individuals or companies included in the class exemption. Until EPA issues a final rule, individuals and companies included in the class exemption will be allowed to continue processing and distributing PCBs in small quantities for research and development.

[55 FR 38999, Sept. 24, 1990, as amended at 59 FR 16998, Apr. 11, 1994]

\section{Subpart F-[Reserved]}

\section{Subpart G-PCB Spill Cleanup Policy} noted.

Source: 52 FR 10705, Apr. 2, 1987, unless otherwise

\section{$\$ 761.120$ Scope.}

(a) General. This policy establishes criteria EPA will use to determine the adequacy of the cleanup of spills resulting from the release of materials containing PCBs at concentrations of $59 \mathrm{ppm}$ or greater. The policy applies to spills which occur after May 4, 1987.

(1) Existing spills (spills which occurred prior to May 4, 1987, are excluded from the scope of this policy for two reasons:

(i) For old spills which have already been discovered, this policy is not intended to require additional cleanup where a party has already cleaned a spill in accordance with requirements imposed by EPA through its regional offices, nor is this policy intended to interfere with ongoing litigation of enforcement actions which bring into issue PCB spills cleanup.

(ii) EPA recognizes that old spills which are discovered after the effective date of this policy will require site-by-site evaluation because of the likelihood that the site involves more pervasive PCB contamination than fresh spills and because old spills are generally more difficult to clean up than fresh spills (particularly on porous surfaces such as concrete). Therefore, spills which occurred before the effective date of this policy are to be decontaminated to requirements established at the discretion of EPA, usually through its regional offices.

(2) EPA expects most PCB spills subject to the TSCA PCB regulations to conform to the typical spill situations considered in developing this policy. This policy does, however, exclude from application of the final numerical cleanup standards certain spill situations from its scope: Spills directly into surface waters, drinking water, sewers, grazing lands, and vegetable gardens. These types of spills are subject to final cleanup standards to be established at the discretion of the regional office. These spills are, however, subject to the immediate notification requirements and measures to minimize further environmental contamination.

(3) For all other spills, EPA generally expects the decontamination standards of this policy to apply. Occasionally, some small percentage of spills covered by this policy may warrant more stringent cleanup requirements because of additional routes of exposure or significantly greater exposures than those assumed in developing the final cleanup standards of this policy. While the EPA regional offices have the authority to require additional cleanup in these circumstances, the Regional Administrator must first make a finding based on the specific facts of a spill that additional cleanup must occur to prevent unreasonable risk. In addition, before a final decision is made to require additional cleanup, the Regional Administrator must notify the Director, Office of Toxic Substances at Headquarters of his/her finding and the basis for the finding.

(4) There may also be exceptional spill situations that requires less stringent cleanup or a different approach to cleanup because of factors associated with the particular spill. These factors may mitigate expected exposures and risks or make cleanup to these requirements impracticable.

(b) Spills that may require more stringent cleanup levels. For spills within the scope of this policy, EPA generally retains, under $\$ 761.135$, the authority to require additional 
cleanup upon finding that, despite good faith efforts by the responsible party, the numerical decontamination levels in the policy have not been met. In addition, EPA foresees the possibility of exceptional spill situations in which site-specific risk factors may warrant additional cleanup to more stringent numerical decontamination levels than are required by the policy. In these situations, the Regional Administrator has the authority to require cleanup to levels lower than those included in this policy upon finding that further cleanup must occur to prevent unreasonable risk. The Regional Administrator will consult with the Director, Office of Toxic Substances, prior to making such a finding.

(1) For example, site-specific characteristics, such as short depth to ground water, type of soil, or the presence of a shallow well, may pose exceptionally high potential for ground water contamination by PCBs remaining after cleanup to the standards specified in this policy. Spills that pose such a high degree of potential for ground water contamination have not been excluded from the policy under paragraph (d) of this section because the presence of such potential may not be readily apparent. EPA feels that automatically excluding such spills from the scope of the policy could result in the delay of cleanup-a particularly undesirable outcome if potential ground water contamination is, in fact, a significant concern.

(2) In those situations, the Regional Administrator may require cleanup in addition to that required under $\$ 761.125$ (b) and (c). However, the Regional Administrator must first make a finding, based on the specific facts of a spill, that additional cleanup is necessary to prevent unreasonable risk. In addition, before making a final decision on additional cleanup, the Regional Administrator must notify the Director of the Office of Toxic Substances of his finding and the basis for the finding.

(c) Flexibility to allow less stringent or alternative requirements. EPA retains the flexibility to allow less stringent or alternative decontamination measures based upon site-specific considerations. EPA will exercise this flexibility if the responsible party demonstrates that cleanup to the numerical decontamination levels is clearly unwarranted because of risk-mitigating factors, that compliance with the procedural requirements or numerical standards in the policy is impracticable at a particular site, or that site-specific characteristics make the costs of cleanup prohibitive. The Regional Administrator will notify the Director of OTS of any decision and the basis for the decision to allow less stringent cleanup. The purpose of this notification is to enable the Director of OTS to ensure consistency of spill cleanup standards under special circumstances across the regions.

(d) Excluded spills.

(1) Although the spill situations in paragraphs (d)(2)(i) through (vi) of this section are excluded from the automatic application of final decontamination standards under $\$ 761.125$ (b) and (c), the general requirements under \$761.125(a) do apply to these spills. In addition, all of these excluded situations require practicable, immediate actions to contain the area of contamination. While these situations may not always require more stringent cleanup measures, the Agency is excluding these scenarios because they will always involve significant factors that may not be adequately addressed by cleanup standards based upon typical spill characteristics.

(2) For the spill situations in paragraphs (d)(2)(i) through (vi) of this section, the responsible party shall decontaminate the spill in accordance with site-specific requirements established by the EPA regional offices.

(i) Spills that result in the direct contamination of surface waters (surface waters include, but are not limited to, "waters of the United States" as defined in Part 122 of this chapter, ponds, lagoons, wetlands, and storage reservoirs).

(ii) Spills that result in the direct contamination of sewers or sewage treatment systems.

(iii) Spills that result in the direct contamination of any private or public drinking water sources or distribution systems.

(iv) Spills which migrate to and contaminate surface waters, sewers, or drinking water supplies before cleanup has been completed in accordance with this policy. lands.

(v) Spills that contaminate animal grazing

(vi) Spills that contaminate vegetable gardens.

(e) Relationship of policy to other statutes. 
(1) This policy does not affect cleanup standards or requirements for the reporting of spills imposed, or to be imposed, under other Federal statutory authorities, including but not limited to, the Clean Water Act (CWA), the Resource Conservation and Recovery Act (RCRA), and the Comprehensive Environmental Response Compensation and Liability Act of 1980 (CERCLA) as amended by the Superfund Amendments and Reauthorization Act (SARA). Where more than one requirement applies, the stricter standard must be met.

(2) The Agency recognizes that the existence of this policy will inevitably result in attempts to apply the standards to situations within the scope of other statutory authorities. However, other statutes require the Agency to consider different or alternative factors in determining appropriate corrective actions. In addition, the types and magnitudes of exposures associated with sites requiring corrective action under other statutes often involve important differences from those expected of the typical, electrical equipment-type spills considered in developing this policy. Thus, cleanups under other statutes, such as RCRA corrective actions or remedial and response actions under SARA may result in different outcomes.

\section{\$761.123 Definitions.}

For purposes of this policy, certain words and phrases are used to denote specific materials, procedures, or circumstances. The following definitions are provided for purposes of clarity and are not to be taken as exhaustive lists of situations and materials covered by the policy.

"Double wash/rinse" means a minimum requirement to cleanse solid surfaces (both impervious and nonimpervious) two times with an appropriate solvent or other material in which PCBs are at least 5 percent soluble (by weight). A volume of PCB-free fluid sufficient to cover the contaminated surface completely must be used in each wash/rinse. The wash/rinse requirement does not mean the mere spreading of solvent or other fluid over the surface, nor does the requirement mean a once-over wipe with a soaked cloth. Precautions must be taken to contain any runoff resulting from the cleansing and to dispose properly of wastes generated during the cleansing.
"High-concentration PCBs" means PCBs that contain $500 \mathrm{ppm}$ or greater PCBs, or those materials which EPA requires to be assumed to contain $500 \mathrm{ppm}$ or greater PCBs in the absence of testing.

"High-contact industrial surface" means a surface in an industrial setting which is repeatedly touched, often for relatively long periods of time. Manned machinery and control panels are examples of high-contact industrial surfaces. High-contact industrial surfaces are generally of impervious solid material. Examples of low-contact industrial surfaces include ceilings, walls, floors, roofs, roadways and sidewalks in the industrial area, utility poles, unmanned machinery, concrete pads beneath electrical equipment, curbing, exterior structural building components, indoor vaults, and pipes.

"High-contact residential/commercial surface" means a surface in a residential/commercial area which is repeatedly touched, often for relatively long periods of time. Doors, wall areas below 6 feet in height, uncovered flooring, windowsills, fencing, bannisters, stairs, automobiles, and children's play areas such as outdoor patios and sidewalks are examples of high-contact residential/commercial surfaces. Examples of low-contact residential/commercial surfaces include interior ceilings, interior wall areas above 6 feet in height, roofs, asphalt roadways, concrete roadways, wooden utility poles, unmanned machinery, concrete pads beneath electrical equipment, curbing, exterior structural building components (e.g., aluminum/vinyl siding, cinder block, asphalt tiles), and pipes.

"Impervious solid surfaces" means solid surfaces which are nonporous and thus unlikely to absorb spilled PCBs within the short period of time required for cleanup of spills under this policy. Impervious solid surfaces include, but are not limited to, metals, glass, aluminum siding, and enameled or laminated surfaces.

"Low-concentration PCBs" means PCBs that are tested and found to contain less than $500 \mathrm{ppm}$ PCBs, or those PCB-containing materials which EPA requires to be assumed to be at concentrations below $500 \mathrm{ppm}$ (i.e., untested mineral oil dielectric fluid).

"Nonimpervious solid surfaces" means solid surfaces which are porous and are more likely to absorb spilled PCBs prior to completion of the cleanup requirements 
prescribed in this policy. Nonimpervious solid surfaces include, but are not limited to, wood, concrete, asphalt, and plasterboard.

"Nonrestricted access areas" means any area other than restricted access, outdoor electrical substations, and other restricted access locations, as defined in this section. In addition to residential/commercial areas, these areas include unrestricted access rural areas (areas of low density development and population where access is uncontrolled by either man-made barriers or naturally occurring barriers, such as rough terrain, mountains, or cliffs).

"Other restricted access (nonsubstation) locations" means areas other than electrical substations that are at least 0.1 kilometer $(\mathrm{km})$ from a residential/commercial area and limited by man-made barriers (e.g., fences and walls) to substantially limited by naturally occurring barriers such as mountains, cliffs, or rough terrain. These areas generally include industrial facilities and extremely remote rural locations. (Areas where access is restricted but are less than 0.1 $\mathrm{km}$ from a residential/commercial area are considered to be residential/commercial areas.)

"Outdoor electrical substations" means outdoor, fenced-off, and restricted access areas used in the transmission and/or distribution of electrical power Outdoor electrical substations restrict public access by being fenced or walled off as defined under $\$ 761.30(1)(1)(i i)$. For purposes of this TSCA policy, outdoor electrical substations are defined as being located at least $0.1 \mathrm{~km}$ from a residential/commercial area. Outdoor fenced-off and restricted access areas used in the transmission and/or distribution of electrical power which are located less than $0.1 . \mathrm{km}$ from a residential/commercial area are considered to be residential/commercial areas.

"PCBs" means polychlorinated biphenyls as defined under $\$ 761.3$. As specified under $\$ 761.1(\mathrm{~b})$, no requirements may be avoided through dilution of the PCB concentration.

"Requirements and standards" means:

(1) "Requirements" as used in this policy refers to both the procedural responses and numerical decontamination levels set forth in this policy as constituting adequate cleanup of PCBs.

(2) "Standards" refers to the numerical decontamination levels set forth in this policy.
"Residential/commercial areas" means those areas where people live or reside, or where people work in other than manufacturing or farming industries. Residential areas include housing and the property on which housing is located, as well as playgrounds, roadways, sidewalks, parks, and other similar areas within a residential community. Commercial areas are typically accessible to both members of the general public and employees and include public assembly properties, institutional properties, stores, office buildings, and transportation centers.

"Responsible party" means the owner of the PCB equipment, facility, or other source of PCBs or his/her designated agent (e.g., a facility manager or foreman).

"Soil" means all vegetation, soils and other ground media, including but not limited to, sand, grass , gravel, and oyster shells. It does not include concrete and asphalt.

"Spill" means both intentional and unintentional spills, leaks, and other uncontrolled discharges where the release results in any quantity of PCBs running off or about to run off the external surface of the equipment or other PCB source, as well as the contamination resulting from those releases. This policy applies to spills of $50 \mathrm{ppm}$ or greater PCBs. The concentration of PCBs spilled is determined by the PCB concentration in the material spilled as opposed to the concentration of PCBs in the material onto which the PCBs were spilled. Where a spill of untested mineral oil occurs, the oil is presumed to contain greater than $\mathbf{5 0}$ ppm, but less than $500 \mathrm{ppm}$ PCBs and is subject to the relevant requirements of this policy.

"Spill area" means the area of soil on which visible traces of the spill can be observed plus a buffer zone of 1 foot beyond the visible traces. Any surface or object (e.g., concrete sidewalk or automobile) within the visible traces area or on which visible traces of the spilled material are observed is included in the spill area. This area represents the minimum area assumed to be contaminated by PCBs in the absence of precleanup sampling data and is thus the minimum area which must be cleaned.

"Spill boundaries" means the actual area of contamination as determined by postcleanup verification sampling or by precleanup sampling to determine actual spill boundaries. EPA can require additional 
cleanup when necessary to decontaminate all areas within the spill boundaries to the levels required in this policy (e.g., additional cleanup will be required if postcleanup sampling indicates that the area decontaminated by the responsible party, such as the spill area as defined in this section, did not encompass the actual boundaries of PCB contamination).

"Standard wipe test" means, for spills of high-concentration PCBs on solid surfaces, a cleanup to numerical surface standards and sampling by a standard wipe test to verify that the numerical standards have been met. This definition constitutes the minimum requirements for an appropriate wipe testing protocol. A standard-size template (10 centimeters $(\mathrm{cm}) \times 10 \mathrm{~cm})$ will be used to delineate the area of cleanup; the wiping medium will be a gauze pad or glass wool of known size which has been saturated with hexane. It is important that the wipe be performed very quickly after the hexane is exposed to air. EPA strongly recommends that the gauze (or glass wool) be prepared with hexane in the laboratory and that the wiping medium be stored in sealed glass vials until it is used for the wipe test. Further, EPA requires the collection and testing of field blanks and replicates.

[52 FR 10705, Apr. 2, 1987; 52 FR 23397, June 19, 1987]

\section{\$761.125 Requirements for PCB spill cleanup.}

(a) General. Unless expressly limited, the reporting, disposal, and precleanup sampling requirements in paragraphs (a) (1) through (3) of this section apply to all spills of PCBs at concentrations of $50 \mathrm{ppm}$ or greater which are subject to decontamination requirements under TSCA, including those spills listed under $\$ 761.120$ (b) which are excluded from the cleanup standards at paragraphs (b) and (c) of this section.

(1) Reporting requirements. The reporting in paragraphs (a)(1) (i) through (iv) of this section is required in addition to applicable reporting requirements under the Clean Water Act (CWA) or the Comprehensive Environmental Response Compensation and Liability Act of 1980 (CERCLA). For example, under the National Contingency Plan all spills involving 10 pounds or more by weight of PCBs must currently be reported to the National Response Center (1-800-424-8802). The requirements in paragraphs (a)(1) (i) through (iv) of this section are designed to be consistent with existing reporting requirements to the extent possible so as to minimize reporting burdens on governments as well as the regulated community.

(i) Where a spill directly contaminates surface water, sewers, or drinking water supplies, as discussed under $\$ 761.120(d)$, the responsible party shall notify the appropriate EPA regional office (the Office of Pesticides and Toxic Substances Branch) and obtain guidance for appropriate cleanup measures in the shortest possible time after discovery, but in no case later than 24 hours after discovery.

(ii) Where a spill directly contaminates grazing lands or vegetable gardens, as discussed under $\$ 761.120(\mathrm{~d})$, the responsible party shall notify the appropriate EPA regional office (the Office of Pesticides and Toxic Substances Branch) and proceed with the immediate requirements specified under paragraph (b) or (c) of this section, depending on the source of the spill, in the shortest possible time after discovery, but in no case later than 24 hours after discovery.

(iii) Where a spill exceeds 10 pounds of PCBs by weight and is not addressed in paragraph (a)(1) (i) or (ii) of this section, the responsible party will notify the appropriate EPA regional office (Pesticides and Toxic Substances Branch) and proceed to decontaminate the spill area in accordance with this TSCA policy in the shortest possible time after discovery, but in no case later than 24 hours after discovery.

(iv) Spills of 10 pounds or less, which are not addressed in paragraph (a)(1) (i) or (ii) of this section, must be cleaned up in accordance with this policy (in order to avoid EPA enforcement liability), but notification of EPA is not required.

(2) Disposal of cleanup debris and materials. All concentrated soils, solvents, rags, and other materials resulting from the cleanup of PCBs under this policy shall be properly stored, labeled, and disposed of in accordance with the provisions of $\$ 761.60$.

(3) Determination of spill boundaries in the absence of visible traces. For spills where there are insufficient visible traces yet there is evidence of a leak or spill, the boundaries of the spill are to be determined by using a statistically based sampling scheme.

(b) Requirements for cleanup of low-concentration spills which involve less than 1 pound of PCBs by weight (less than 270 gallons of untested mineral oil)- 
(1) Decontamination requirements. Spills of less than $\mathbf{2 7 0}$ gallons of untested mineral oil, low-concentration PCBs, as defined under \$761.123, which involve less than 1 pound of PCBs by weight (e.g., less than 270 gallons of untested mineral oil containing less than 500 ppm PCBs) shall be cleaned in the following manner:

(i) Solid surfaces must be double washed/rinsed (as defined under \$761.123); except that all indoor, residential surfaces other than vault areas must be cleaned to 10 micrograms per 100 square centimeters (10 $\mu \mathrm{g} / 100 \mathrm{~cm}^{2}$ ) by standard commercial wipe tests.

(ii) All soil within the spill area (i.e., visible traces of soil and a buffer of 1 lateral foot around the visible traces) must be excavated, and the ground be restored to its original configuration by back-filling with clean soil (i.e., containing less than $1 \mathrm{ppm}$ PCBs).

(iii) Requirements of paragraphs (b)(1) (i) and (ii) of this section must be completed within 48 hours after the responsible party was notified or became aware of the spill.

(2) Effect of emergency or adverse weather. Completion of cleanup may be delayed beyond 48 hours in case of circumstances including but not limited to, civil emergency, adverse weather conditions, lack of access to the site, and emergency operating conditions. The occurrence of a spill on a weekend or overtime costs are not acceptable reasons to delay response. Completion of cleanup may be delayed only for the duration of the adverse conditions. If the adverse weather conditions, or time lapse due to other emergency, has left insufficient visible traces, the responsible party must use a statistically based sampling scheme to determine the spill boundaries as required under paragraph (a)(3) of this section.

(3) Records and certification. At the completion of cleanup, the responsible party shall document the cleanup with records and certification of decontamination. The records and certification must be maintained for a period of 5 years. The records and certification shall consist of the following:

(i) Identification of the source of the spill (e.g., type of equipment).

(ii) Estimated or actual date and time of the spill occurrence.

(iii) The date and time cleanup was completed or terminated (if cleanup was delayed by emergency or adverse weather: the nature and duration of the delay).

(iv) A brief description of the spill location.

(v) Precleanup sampling data used to establish the spill boundaries if required because of insufficient visible traces, and a brief description of the sampling methodology used to establish the spill boundaries.

(vi) A brief description of the solid surfaces cleaned and of the double wash/rinse method used.

(vii) Approximate depth of soil excavation and the amount of soil removed.

(viii) A certification statement signed by the responsible party stating that the cleanup requirements have been met and that the information contained in the record is true to the best of his/her knowledge.

(ix) While not required for compliance with this policy, the following information would be useful if maintained in the records:

(A) Additional pre- or post-cleanup sampling.

(B) The estimated cost of the cleanup by man-hours, dollars, or both.

(c) Requirements for cleanup of high-concentration spills and lowconcentration spills involving I pound or more PCBs by weight ( 270 gallons or more of untested mineral oil). Cleanup of low-concentration spills involving $1 \mathrm{lb}$ or more PCBs by weight and of all spills of materials other than low-concentration materials shall be considered complete if all of the immediate requirements, cleanup standards, sampling, and recordkeeping requirements of paragraphs (c) (1) through (5) of this section are met.

(1) Immediate requirements. The four actions in paragraphs (c)(1) (i) through (iv) of this section must be taken as quickly as possible and within no more than 24 hours (or within 48 hours for PCB Transformers) after the responsible party was notified or became aware of the spill, except that actions described in paragraphs (c)(1) (ii) through (iv) of this section can be delayed beyond 24 hours if circumstances (e.g., civil emergency, hurricane, tornado, or other similar adverse weather conditions, lack of access due to physical impossibility, or emergency operating conditions) so require for the duration of the adverse conditions. The occurrence of a spill on a weekend or overtime costs are not acceptable reasons to 
delay response. Owners of spilled PCBs who have delayed cleanup because of these types of circumstances must keep records documenting the fact that circumstances precluded rapid response.

(i) The responsible party shall notify the EPA regional office and the NRC as required by $\$ 761.125(a)(1)$ or by other applicable statutes.

(ii) The responsible party shall effectively cordon off or otherwise delineate and restrict an area encompassing any visible traces plus a 3-foot buffer and place clearly visible signs advising persons to avoid the area to minimize the spread of contamination as well as the potential for human exposure.

(iii) The responsible party shall record and document the area of visible contamination, noting the extent of the visible trace areas and the center of the visible trace area. If there are no visible traces, the responsible party shall record this fact and contact the regional office of the EPA for guidance in completing statistical sampling of the spill area to establish spill boundaries.

(iv) The responsible party shall initiate cleanup of all visible traces of the fluid on hard surfaces and initiate removal of all visible traces of the spill on soil and other media, such as gravel, sand, oyster shells, etc.

(v) If there has been a delay in reaching the site and there are insufficient visible traces of PCBs remaining at the spill site, the responsible party must estimate (based on the amount of material missing from the equipment or container) the area of the spill and immediately cordon off the area of suspect contamination. The responsible party must then utilize a statistically based sampling scheme to identify the boundaries of the spill area as soon as practicable.

(vi) Although this policy requires certain immediate actions, as described in paragraphs (c)(1)(i) through (iv) of this section, EPA is not placing a time limit on completion of the cleanup effort since the time required for completion will vary from case to case. However, EPA expects that decontamination will be achieved promptly in all cases and will consider promptness of completion in determining whether the responsible party made good faith efforts to clean up in accordance with this policy.

(2) Requirements for decontaminating spills in outdoor electrical substations. Spills which occur in outdoor electrical substations, as defined under $\$ 761.123$, shall be decontaminated in accordance with paragraphs (c)(2)(i) and (ii) of this section. Conformance to the cleanup standards under paragraphs (c)(2)(i) and (ii) of this section shall be verified by post-cleanup sampling as specified under $\$ 761.130$. At such times as outdoor electrical substations are converted to another use, the spill site shall be cleaned up to the nonrestricted access requirements under paragraph (c)(4) of this section.

(i) Contaminated solid surfaces (both impervious and non-impervious) shall be cleaned to a PCB concentration of 100 micrograms $(\mu \mathrm{g}) / 100$ square centimeters $\left(\mathrm{cm}^{2}\right.$ ) (as measured by standard wipe tests).

(ii) At the option of the responsible party, soil contaminated by the spill will be cleaned either to $25 \mathrm{ppm}$ PCBs by weight, or to 50 ppm PCBs by weight provided that a label or notice is visibly placed in the area. Upon demonstration by the responsible party that cleanup to $25 \mathrm{ppm}$ or $50 \mathrm{ppm}$ will jeopardize the integrity of the electrical equipment at the substation, the EPA regional office may establish an alternative cleanup method or level and place the responsible party on a reasonably timely schedule for completion of cleanup.

(3) Requirements for decontaminating spills in other restricted access areas. Spills which occur in restricted access locations other than outdoor electrical substations, as defined under $\$ 761.123$, shall be decontaminated in accordance with paragraphs (c)(3)(i) through (v) of this section. Conformance to the cleanup standards in paragraphs (c)(3)(i) through (v) of this section shall be verified by postcleanup sampling as specified under $\$ 761.130$. At such times as restricted access areas other than outdoor electrical substations are converted to another use, the spill site shall be cleaned up to the nonrestricted access area requirements of paragraph $(c)(4)$ of this section.

(i) High-contact solid surfaces, as defined under $\$ 761.163$ shall be cleaned to $10 \mu \mathrm{g} / 100$ $\mathrm{cm}^{2}$ (as measured by standard wipe tests).

(ii) Low-contact, indoor, impervious solid surfaces will be decontaminated to $10 \mu \mathrm{g} / 100$ $\mathrm{cm}^{2}$.

(iii) At the option of the responsible party, low-contact, indoor, nonimpervious surfaces will be cleaned either to $10 \mu \mathrm{g} / 100 \mathrm{~cm}^{2}$ or to $100 \mu \mathrm{g} / 100 \mathrm{~cm}^{2}$ and encapsulated. The Regional Administrator, however, retains the authority to disallow the encapsulation option 
for a particular spill situation upon finding that the uncertainties associated with that option pose special concerns at that site. That is, the Regional Administrator would not permit encapsulation if he/she determined that if the encapsulation failed the failure would create an imminent hazard at the site.

(iv) Low-contact, outdoor surfaces (both impervious and nonimpervious) shall be cleaned to $100 \mu \mathrm{g} / 100 \mathrm{~cm}^{2}$.

(v) Soil contaminated by the spill will be cleaned to 25 ppm PCBs by weight.

(4) Requirements for decontaminating spills in nonrestricted access areas. Spills which occur in nonrestricted access locations, as defined under $\$ 761.123$, shall be decontaminated in accordance with paragraphs (c)(4)(i) through (v) of this section. Conformance to the cleanup standards at paragraphs (c)(4)(i) through (v) of this section shall be verified by postcleanup sampling as specified under \$761.130.

(i) Furnishings, toys, and other easily replaceable household items shall be disposed of in accordance with the provisions of $\$ 761.60$ and replaced by the responsible party.

(ii) Indoor solid surfaces and high-contact outdoor solid surfaces, defined as high contact residential/commercial surfaces under $\$ 761.123$, shall be cleaned to $10 \mu \mathrm{g} / 100$ $\mathrm{cm}^{2}$ (as measured by standard wipe tests).

(iii) Indoor vault areas and low-contact, outdoor, impervious solid surfaces shall be decontaminated to $10 \mu \mathrm{g} / 100 \mathrm{~cm}^{2}$.

(iv) At the option of the responsible party, low-contact, outdoor, nonimpervious solid surfaces shall be either cleaned to $10 \mu \mathrm{g} / 100$ $\mathrm{cm}^{2}$ or cleaned to $100 \mu \mathrm{g} / 100 \mathrm{~cm}^{2}$ and encapsulated. The Regional Administrator, however, retains the authority to disallow the encapsulation option for a particular spill situation upon finding that the uncertainties associated with that option pose special concerns at that site. That is, the Regional Administrator would not permit encapsulation if he/she determined that if the encapsulation failed the failure would create an imminent hazard at the site.

(v) Soil contaminated by the spill will be decontaminated to $10 \mathrm{ppm}$ PCBs by weight provided that soil is excavated to a minimum depth of 10 inches. The excavated soil will be replaced with clean soil, i.e., containing less than 1 ppm PCBs, and the spill site will be restored (e.g., replacement of turf).
(5) Records. The responsible party shall document the cleanup with records of decontamination. The records must be maintained for a period of 5 years. The records and certification shall consist of the following: .

(i) Identification of the source of the spill, e.g., type of equipment.

(ii) Estimated or actual date and time of the spill occurrence.

(iii) The date and time cleanup was completed or terminated (if cleanup was delayed by emergency or adverse weather: the nature and duration of the delay).

(iv) A brief description of the spill location and the nature of the materials contaminated. This information should include whether the spill occurred in an outdoor electrical substation, other restricted access location, or in a nonrestricted access area.

(v) Precleanup sampling data used to establish the spill boundaries if required because of insufficient visible traces and a brief description of the sampling methodology used to establish the spill boundaries.

(vi) A brief description of the solid surfaces cleaned.

(vii) Approximate depth of soil excavation and the amount of soil removed.

(viii) Postcleanup verification sampling data and, if not otherwise apparent from the documentation, a brief description of the sampling methodology and analytical technique used.

(ix) While not required for compliance with this policy, information on the estimated cost of cleanup (by man-hours, dollars, or both) would be useful if maintained in the records.

[52 FR 10705, Apr. 2, 1987, as amended at 53 FR 40884, Oct. 19, 1988]

\section{\$761.130 Sampling requirements.}

Postcleanup sampling is required to verify the level of cleanup under $\$ 761.125$ (c) (2) through (4). The responsible party may use any statistically valid, reproducible, sampling scheme (either random samples or grid samples) provided that the requirements of paragraphs (a) and (b) of this section are satisfied.

(a) The sampling area is the greater of (1) an area equal to the area cleaned plus an additional 1-foot boundary, or (2) an area 20 percent larger than the original area of contamination. 
(b) The sampling scheme must ensure 95 percent confidence against false positives.

(c) The number of samples must be sufficient to ensure that areas of contamination of a radius of 2 feet or more within the sampling area will be detected, except that the minimum number of samples is 3 and the maximum number of samples is 40.

(d) The sampling scheme must include calculation for expected variability due to analytical error.

(e) EPA recommends the use of a sampling scheme developed by the Midwest Research Institute (MRI) for use in EPA enforcement inspections: "Verification of PCB Spill Cleanup by Sampling and Analysis." Guidance for the use of this sampling scheme is available in the MRI report "Field Manual for Grid Sampling of PCB Spill Sites to Verify Cleanup." Both the MRI sampling scheme and the guidance document are available from the TSCA Assistance Office, Environmental Protection Agency, Rm. E-543, 401 M St. SW., Washington, DC 20460 (202-554-1404). The major advantage of this sampling scheme is that it is designed to characterize the degree of contamination within the entire sampling area with a high degree of confidence while using fewer samples than any other grid or random sampling scheme. This sampling scheme also allows some sites to be characterized on the basis of composite samples.

(f) EPA may, at its discretion, take samples from any spill site. If EPA's sampling indicates that the remaining concentration level exceeds the required level, EPA will require further cleanup. For this purpose, the numerical level of cleanup required for spills cleaned in accordance with $\$ 761.125(\mathrm{~b})$ is deemed to be the equivalent of numerical cleanup requirements required for cleanups under $\$ 761.125(\mathrm{c})(2)$ through (4). Using its best engineering judgment, EPA may sample a statistically valid random or grid sampling technique, or both. When using engineering judgment or random "grab" samples, EPA will take into account that there are limits on the power of a grab sample to dispute statistically based sampling of the type required of the responsible party. EPA headquarters will provide guidance to the EPA regions on the degree of certainty associated with various grab sample results.
$\$ 761.135$ Effect of compliance with this policy and enforcement.

(a) Although a spill of material containing $50 \mathrm{ppm}$ or greater PCBs is considered improper PCB disposal, this policy establishes requirements that EPA considers to be adequate cleanup of the spilled PCBs. Cleanup in accordance with this policy means compliance with the procedural as well as the numerical requirements of this policy. Compliance with this policy creates a presumption against both enforcement action for penalties and the need for further cleanup under TSCA. The Agency reserves the right, however, to initiate appropriate action to compel cleanup where, upon review of the records of cleanup or EPA sampling following cleanup, EPA finds that the decontamination levels in the policy have not been achieved. The Agency also reserves the right to seek penalties where the Agency believes that the responsible party has not made a good faith effort to comply with all provisions of this policy, such as prompt notification of EPA of a spill, recordkeeping, etc.

(b) EPA's exercise of enforcement discretion does not preclude enforcement action under other provisions of TSCA or any other Federal statute. This includes, even in cases where the numerical decontamination levels set forth in this policy have been met, civil or criminal action for penalties where EPA believes the spill to have been the result of gross negligence or knowing violation.

\section{Subparts $\mathrm{H}$ and $\mathrm{I}-$ [Reserved]}

\section{Subpart J-General Records and Reports}

\section{\$761.180 Records and monitoring.}

This section contains recordkeeping and reporting requirements that apply to PCBs, PCB Items, and PCB storage and disposal facilities that are subject to the requirements of the part.

(a) PCBs and PCB Items in service or projected for disposal. Beginning February 5 , 1990 , each owner or operator of a facility, other than a commercial storer or a disposer of PCB waste, using or storing at any one time at least 45 kilograms (99.4 pounds) of PCBs contained in PCB Container(s), or one or more PCB Transformers, or 50 or more PCB Large High or Low Voltage Capacitors shall develop and maintain at the facility, or a central facility provided they are maintained 
at that facility, all annual records and the written annual document $\log$ of the disposition of PCBs and PCB Items. The written annual document $\log$ must be prepared for each facility by July 1 covering the previous calendar year (January through December). The annual document log shall be maintained for at least 3 years after the facility ceases using or storing PCBs and PCB Items in the quantities prescribed in this paragraph. Annual records (manifests and certificates of disposal) shall be maintained for the same period. The annual records and the annual document $\log$ shall be available for inspection at the facility where they are maintained by authorized representatives of EPA during normal business hours, and each owner or operator of a facility subject to these requirements shall know the location of these records. All records and annual documents required to be prepared and maintained by this section prior to February 5, 1990 shall continue to be maintained at the facility for the same time as the annual records and the annual document $\log$. The annual document required for 1989 shall cover the period from January 1, 1989 to February 5, 1990.

(1) The annual records shall include the following:

(i) All signed manifests generated by the facility during the calendar year.

(ii) All Certificates of Disposal that have been received by the facility during the calendar year.

(2) The written annual document log shall include the following:

(i) The name, address, and EPA identification number of the facility covered by the annual document $\log$ and the calendar year covered by the annual document log.

(ii) The unique manifest number of every manifest generated by the facility during the calendar year, and from each manifest and for unmanifested waste that may be stored at the facility, the following information:

(A) For bulk PCB waste (e.g., in a tanker or truck), its weight in kilograms, the first date it was removed from service for disposal, the date it was placed into transport for off-site storage or disposal, and the date of disposal, if known.

(B) The serial number (if available) or other means of identifying each PCB Article (e.g., transformer or capacitor), the weight in kilograms of the PCB waste in each transformer or capacitor, the date it was removed from service for disposal, the date it was placed in transport for off-site storage or disposal, and the date of disposal, if known.

(C) A unique number identifying each PCB Container, a description of the contents of each PCB Container, such as liquid, soil, cleanup debris, etc., including the total weight of the material in kilograms in each PCB Container, the first date material placed in each PCB Container was removed from service for disposal, and the date each PCB Container was placed in transport for off-site storage or disposal, and the date of disposal (if known).

(D) A unique number identifying each PCB Article Container, a description of the contents of each PCB Article Container, such as pipes, capacitors, electric motors, pumps, etc., including the total weight in kilograms of the content of each PCB Article Container, the first date a PCB Article placed in each PCB Article Container was removed from service for disposal, and the date the PCB Article Container was placed in transport for off-site storage or disposal, and the date of disposal (if known).

(iii) The total number by specific type of PCB Articles and the total weight in kilograms of PCBs in PCB Articles, the total number of PCB Article Containers and total weight in kilograms of the contents of PCB Article Containers, the total number of PCB Containers and the total weight in kilograms of the contents of PCB Containers, and the total weight in kilograms of bulk PCB waste that was placed into storage for disposal or disposed during the calendar year.

(iv) The total number of PCB Transformers and total weight in kilograms of PCBs contained in the transformers remaining in service at the end of the calendar year.

(v) The total number of Large High or Low Voltage PCB Capacitors remaining in service at the end of the calendar year.

(vi) The total weight in kilograms of any PCBs and PCB Items in PCB Containers, including the identification of container contents, remaining in service at the facility at the end of the calendar year.

(vii) For any PCBs or PCB item received from or shipped to another facility owned or operated by the same generator, the information required under paragraph (a)(2)(ii)(A) through (a)(2)(ii)(D) of this section.

(viii) A record of each telephone call, or other means of verification agreed upon by 
both parties, made to each designated commercial storer or designated disposer to confirm receipt of $\mathrm{PCB}$ waste transported by an independent transporter, as required by $\$ 761.208$.

(b) Disposers and commercial storers of $P C B$ waste. Beginning February 5, 1990, each owner or operator of a facility (including high efficiency boiler operations) used for the commercial storage or disposal of PCBs and PCB Items shall maintain annual records on the disposition of all PCBs and PCB items at the facility and prepare and maintain a written annual document $\log$ that includes the information required by paragraphs $(b)(2)$ of this section for PCBs and PCB Items that were handled as PCB waste at the facility. The written annual document $\log$ shall be prepared by July 1 for the previous calendar year (January through December). The written annual document $\log$ shall be maintained at each facility for at least 3 years after the facility is no longer used for the storage or disposal of PCBs and PCB Items except that, in the case of chemical waste landfills, the annual document $\log$ shall be maintained at least 20 years after the chemical waste landfill is no longer used for the disposal of PCBs and PCB Items. The annual records shall be maintained for the same period. The annual records and written annual document $\log$ shall be available at the facility for inspection by authorized representatives of the EPA. All records and annual documents required to be prepared and maintained by this section prior to February 5,1990 shall continue to be maintained at the facility for the same time as the annual records and the annual document log. The annual document for 1989 shall cover the period from January 1, 1989 to February 5, 1990. From the written annual document log the owner or operator of a facility must prepare the annual report containing the information required by paragraphs (b)(3)(i) through (b) (3)(vi) of this section for PCBs and PCB Items that were handled as PCB waste at the facility during the previous calendar year (January through December). The annual report must be submitted by July 15 of each year for the preceding calendar year. If the facility ceases commercial PCB storage or disposal operations, the owner or operator of the facility shall provide at least 60 days advance written notice to the Regional Administrator for the region in which the facility is located of the date the facility intends to begin closure.

(1) The annual records shall include the following:

(i) All signed manifests generated or received at the facility during the calendar year.

(ii) All Certificates of Disposal that have been generated or received by the facility during the calendar year.

(2) The written annual document log shall include the following:

(i) The name, address, and EPA identification number of the storage or disposal facility covered by the annual document $\log$ and the calendar year covered by the annual document log.

(ii) For each manifest generated or received by the facility during the calendar year, the unique manifest number and the name and address of the facility that generated the manifest and the following information:

(A) For bulk PCB waste (e.g., in a tanker or truck), its weight in kilograms, the first date PCB waste placed in the tanker or truck was removed from service for disposal, the date it was received at the facility, the date it was placed in transport for off-site disposal (if applicable), and the date of disposal (if known).

(B) The serial number or other means of identifying each PCB Article, not in a PCB Container or PCB Article Container, the weight in kilograms of the PCB waste in the PCB Article, the date it was removed from service for disposal, the date it was received at the facility, the date it was placed in transport for off-site disposal (if applicable), and the date of disposal (if known).

(C) The unique number assigned by the generator identifying each PCB Container, a description of the contents of each PCB Container, such as liquid, soil, cleanup debris, etc., including the total weight of the PCB waste in kilograms in each PCB Container, the first date PCB waste placed in each PCB Container was removed from service for disposal, the date it was received at the facility, the date each PCB Container was placed in transport for off-site storage or disposal (as applicable), and the date the PCB Container was disposed of (if known).

(D) The unique number assigned by the generator identifying each PCB Article Container, a description of the contents of each PCB Article Container, such as pipes, 
capacitors, electric motors, pumps, etc., including the total weight in kilograms of the PCB waste in each PCB Article Container, the first date a PCB Article placed in each PCB Article Container was removed from service for disposal, the date it was received at the facility, the date each PCB Article Container was placed in transport for off-site storage or disposal (as applicable), and the date the PCB Container was disposed (if known).

(E) Disposers of PCB waste shall include the confirmed date of disposal for items in paragraphs (b)(2)(ii)(A) through (b)(2)(ii)(D) of this section.

(iii) For any PCB waste disposed at a facility that generated the PCB waste or any PCB waste that was not manifested to the facility, the information required under paragraph (b)(2)(ii)(A) through (b)(2)(ii)(E) of this section.

(3) The owner or operator of a PCB disposal or commercial storage facility shall submit an annual report, which briefly summarizes the records and annual document $\log$ required to be maintained and prepared under paragraphs (b)(1) and (b)(2) of this section, to the Regional Administrator of the EPA region in which the facility is located by July 15 of each year, beginning with July 15 , 1991. The first annual report submitted on July 15,1991 , shall be for the period starting February 5, 1990 and ending December 31, 1990. The annual report shall contain no confidential business information. The annual report shall consist of the information listed in paragraphs (b)(3)(i) through (b)(3)(vi) of this section.

(i) The name, address, and EPA identification number of the facility covered by the annual report for the calendar year.

(ii) A list of the numbers of all signed manifests of PCB waste initiated or received by the facility during that year.

(iii) The total weight in kilograms of bulk PCB waste, $P C B$ waste in $P C B$ Transformers, PCB waste in PCB Large High or Low Voltage Capacitors, PCB waste in PCB Article Containers, and PCB waste in PCB Containers in storage at the facility at the beginning of the calendar year, received or generated at the facility, transferred to another facility, or disposed of at the facility during the calendar year. The information must be provided for each of these categories, as appropriate. (iv) The total number of PCB Transformers, the total number of PCB Large High or Low Voltage Capacitors, the total number of $\mathrm{PCB}$ Article Containers, and the total number of PCB Containers in storage at the facility at the beginning of the calendar year, received or generated at the facility, transferred to another facility, or disposed of at the facility during the calendar year. The information must be provided for each of these categories, as appropriate.

(v) The total weight in kilograms of each of the following PCB categories: bulk PCB waste, PCB waste in PCB Transformers, PCB waste in PCB Large High or Low Voltage Capacitors, PCB waste in PCB Article Containers, and PCB waste in PCB Containers remaining in storage for disposal at the facility at the end of the calendar year.

(vi) The total number of PCB Transformers, the total number of PCB Large High or Low Voltage Capacitors, the total number of PCB Article Containers, and the total number of PCB Containers remaining in storage for disposal at the facility at the end of the calendar year.

(vii) The requirement to submit annual reports to the Regional Administrator continues until the submission of the annual report for the calendar year during which the facility ceases PCB storage or disposal operations. Storage operations have not ceased until all PCB waste, including any PCB waste generated during closure, has been removed from the facility.

(4) Whenever a commercial storer of PCB waste accepts PCBs or PCB Items at his storage facility and transfers the PCB waste off-site to another facility for storage or disposal, the commercial storer of PCB waste shall initiate a manifest under subpart $\mathrm{K}$ of this part for the transfer of PCBs or PCB Items to the next storage or disposal facility.

Note: Any requirements for weights in kilograms of PCBs may be calculated values if the internal volume of PCBs in containers and transformers is known and included in the reports, together with any assumptions on the density of the PCBs contained in the containers or transformers. If the internal volume of PCBs is not known, a best estimate may be used.

(c) Incineration facilities. Each owner or operator of a PCB incinerator facility shall collect and maintain for a period of 5 years from the date of collection the following information, in addition to the information required in paragraph (b) of this section:

(1) When PCBs are being incinerated, the following continuous and short-interval data: 
(i) Rate and quantity of PCBs fed to the combustion system as required in $\$ 761.70(\mathrm{a})(3)$;

(ii) Temperature of the combustion process as required in $\$ 761.70(\mathrm{a})(4)$; and

(iii) Stack emission product to include $\mathrm{O}_{2}$, $\mathrm{CO}$, and $\mathrm{Co} 2$ as required in $\$ 761.70(a)(7)$.

(2) When PCBs are being incinerated, data and records on the monitoring of stack emissions as required in \$761.70(a)(6).

(3) Total weight in kilograms of any solid residues generated by the incineration of PCBs and PCB Items during the calendar year, the total weight in kilograms of any solid residues disposed of by the facility in chemical waste landfills, and the total weight in kilograms of any solid residues remaining on the facility site.

(4) When PCBs and PCB Items are being incinerated, additional periodic data shall be collected and maintained as specified by the Regional Administrator pursuant to $\$ 761.70(d)(4)$.

(5) Upon any suspension of the operation of any incinerator pursuant to $\$ 761.70(a)(8)$, the owner or operator of such an incinerator shall prepare a document. The document shall, at a minimum, include the date and time of the suspension and an explanation of the circumstances causing the suspension of operation. The document shall be sent to the appropriate Regional Administrator within 30 days of any such suspension.

(d) Chemical waste landfill facilities. Each owner or operator of a PCB chemical waste landfill facility shall collect and maintain until at least 20 years after the chemical waste landfill is no longer used for the disposal of PCBs the following information in addition to the information required in paragraph (b) of this section:

(1) Any water analysis obtained in compliance with $\$ 761.75(\mathrm{~b})(6)(\mathrm{iii})$; and

(2) Any operations records including burial coordinates of wastes obtained in compliance with $\$ 761.75$ (b)(8)(ii).

(e) High efficiency boiler facilities. Each owner or operator of a high efficiency boiler used for the disposal of liquids between 50 and 500 ppm PCB shall collect and maintain for a period of 5 years the following information, in addition to the information required in paragraph (b) of this section:

(1) For each month PCBs are burned in the boiler the carbon monoxide and excess oxygen data required in $\$ 761.60(a)(2)$ (iii)(A)(8) and \$761.60(a)(3)(iii)(A)(8);
(2) The quantity of PCBs burned each month as required in $\$ 761.60(\mathrm{a})(2)(\mathrm{iii})(\mathrm{A})(7)$ and $\$ 761.60(\mathrm{a})(3)(\mathrm{iii})(\mathrm{A})(7)$; and

(3) For each month PCBs (other than mineral oil dielectric fluid) are burned, chemical analysis data of the waste as required in $\$ 761.60(\mathrm{a})(3)$ (iii)(B)(6).

(f) Retention of special records by storage and disposal facilities. In addition to the information required to be maintained under paragraphs (b), (c), (d) and (e) of this section, each owner or operator of a PCB storage or disposal facility (including high efficiency boiler operations) shall collect and maintain for the time period specified in paragraph (b) of this section the following data:

(1) All documents, correspondence, and data that have been provided to the owner or operator of the facility by any State or local government agency and that pertain to the storage or disposal of PCBs and PCB Items at the facility.

(2) All documents, correspondence, and data that have been provided by the owner or operator of the facility to any State or local government agency and that pertain to the storage or disposal of PCBs and PCB Items at the facility.

(3) Any applications and related correspondence sent by the owner or operator of the facility to any local, State, or Federal authorities in regard to waste water discharge permits, solid waste permits, building permits, or other permits or authorizations such as those required by $\$ \S 761.70(d)$ and 761.75(c).

(Sec. 6, Pub. L. 94-469, 90 Stat. 2020 (15 U.S.C. 2605)

[44 FR 31542, May 31, 1979. Redesignated at 47 FR 19527, May 6, 1982, and further redesignated at $47 \mathrm{FR}$ 37360 , Aug. 25, 1982; 49 FR 28191, July 10, 1984; 53 FR 12524, Apr. 15, 1988, as amended at 54 FR 52750, Dec. 21, 1989; 55 FR 26205, June 27, 1990; 58 FR 34205, June 23, 1993]

\section{$\$ 761.185$ Certification program and retention of records by importers and persons generating PCBs in excluded manufacturing processes.}

(a) In addition to meeting the basic requirements of $\$ 761.1(f)$ and the definition of excluded manufacturing processes at $\$ 761.3$, manufacturers with processes inadvertently generating PCBs and importers of products containing inadvertently generated PCBs must report to EPA any excluded manufacturing process or imports for which the concentration of PCBs in 
products leaving the manufacturing site or imported is greater than 2 micrograms per gram $(2 \mu \mathrm{g} / \mathrm{g}$, roughly $2 \mathrm{ppm})$ for any resolvable gas chromatographic peak. Such reports must be filed by October 1, 1984 or, if no processes or imports require reports at the time, within 90 days of having processes or imports for which such reports are required.

(b) Manufacturers required to report by paragraph (a) of this section must transmit a letter notifying EPA of the number, the type, and the location of excluded manufacturing processes in which PCBs are generated when the PCB level in products leaving any manufacturing site is greater than $2 \mu \mathrm{g} / \mathrm{g}$ for any resolvable gas chromatographic peak. Importers required to report by paragraph (a) of this section must transmit a letter notifying EPA of the concentration of PCBs in imported products when the PCB concentration of products being imported is greater than $2 \mu \mathrm{g} / \mathrm{g}$ for any resolvable gas chromatographic peak. Persons must also certify the following:

(1) Their compliance with all applicable requirements of $\$ 761.1(f)$, including any applicable requirements for air and water releases and process waste disposal.

(2) Whether determinations of compliance are based on actual monitoring of PCB levels or on theoretical assessments.

(3) That such determinations of compliance are being maintained.

(4) If the determination of compliance is based on a theoretical assessment, the letter must also notify EPA of the estimated PCB concentration levels generated and released.

(c) Any person who reports pursuant to paragraph (a) of this section:

(1) Must have performed either a theoretical analysis or actual monitoring of PCB concentrations.

(2) Must maintain for a period of three years after ceasing process operations or importation, or for seven years, whichever is shorter, records containing the following information:

(i) Theoretical analysis. Manufacturers records must include: the reaction or reactions believed to be generating PCBs; the levels of PCBs generated; and the levels of PCBs released. Importers records must include: the reaction or reactions believed to be generating PCBs and the levels of PCBs generated; the basis for all estimations of PCB concentrations; and the name and qualifications of the person or persons performing the theoretical analysis; or

(ii) Actual monitoring.

(A) The method of analysis.

(B) The results of the analysis, including data from the Quality Assurance Plan.

(C) Description of the sample matrix.

(D) The name of the analyst or analysts.

(E) The date and time of the analysis.

(F) Numbers for the lots from which the samples are taken.

(d) The certification required by paragraph (b) of this section must be signed by a responsible corporate officer. This certification must be maintained by each facility or importer for a period of three years after ceasing process operation or importation, or for seven years, whichever is shorter, and must be made available to EPA upon request. For the purpose of this section, a responsible corporate officer means:

(1) A president, secretary, treasurer, or vice-president of the corporation in charge of a principal business function, or any other person who performs similar policy or decision-making functions for the corporation.

(2) The manager of one or more manufacturing, production, or operating facilities employing more than 250 persons or having gross annual sales or expenditures exceeding $\$ 25,000,000$ (in second quarter 1980 dollars), if authority to sign documents has been assigned or delegated to the manager in accordance with corporate procedures.

(e) Any person signing a document under paragraph (d) of this section shall also make the following certification:

I certify under penalty of law that this document and all attachments were prepared under my direction or supervision in accordance with a system designed to assure that qualified personnel properly gather and evaluate information. Based on my inquiry of the person or persons directly responsible for gathering information, the information is, to the best of my knowledge and belief, true, accurate, and complete. I am aware that there are significant penalties for falsifying information, including the possibility of fines and imprisonment for knowing violations.

Dated:

Signature:

(f) This report must be submitted to the TSCA Document Processing Center (TS-790), Rm. L-100, Office of Toxic Substances, Environmental Protection Agency, 401 M St., SW., Washington, DC 
20460, ATTN: PCB Notification. This report must be submitted by October 1,1984 or within 90 days of starting up processes or commencing importation of PCBs.

(g) This certification process must be repeated whenever process conditions are significantly modified to make the previous certification no longer valid.

(Sec. 6, Pub. L. 94-469, 90 Stat. 2020 (15 U.S.C. 2605)

[49 FR 28191, July 10, 1984; 49 FR 33019, Aug. 20, 1984, as amended at 53 FR 12524, Apr. 15, 1988; 58 FR 34205, June 23, 1993]

\section{$\$ 761.187$ Reporting importers and by persons generating PCBs in excluded manufacturing processes.}

In addition to meeting the basic requirements of \$761.1(f) and the definition of excluded manufacturing process at $\$ 761.3$, PCB-generating manufacturing processes or importers of PCB-containing products shall be considered "excluded manufacturing processes" only when the following conditions are met:

(a) Data are reported to the EPA by the owner/operator or importer concerning the total quantity of PCBs in product from excluded manufacturing processes leaving any manufacturing site in any calendar year when such quantity exceeds 0.0025 percent of that site's rated capacity for such manufacturing processes as of October 1 , 1984; or the total quantity of PCBs imported in any calendar year when such quantity exceeds 0.0025 percent of the average totai quantity of such product containing PCBs imported by such importer during the years $1978,1979,1980,1981$ and 1982.

(b) Data are reported to the EPA by the owner/operator concerning the total quantity of inadvertently generated PCBs released to the air from excluded manufacturing processes at any manufacturing site in any calendar year when such quantity exceeds 10 pounds.

(c) Data are reported to the EPA by the owner/operator concerning the total quantity of inadvertently generated PCBs released to water from excluded manufacturing processes from any manufacturing site in any calendar year when such quantity exceeds 10 pounds.

(d) These reports must be submitted to the TSCA Document Processing Center (TS-790), Rm. L-100, Office of Toxic Substances, Environmental Protection
Agency, 401 M St., SW., Washington, DC 20460, ATTN: PCB Notification.

(Sec. 6, Pub. L. 94-469, 90 Stat. 2020 (15 U.S.C. 2605) [49 FR 28192, July 10, 1984, as amended at 53 FR 12524 , Apr. 15, 1988; 58 FR 34205, June 23, 1993]

\section{$\$ 761.193$ Maintenance of monitoring records by persons who import, manufacture, process, distribute in commerce, or use chemicals containing inadvertently generated PCBs.}

(a) Persons who import, manufacture, process, distribute in commerce, or use chemicals containing PCBs present as a result of inadvertent generation or recycling who perform any actual monitoring of PCB concentrations must maintain records of any such monitoring for a period of three years after a process ceases operation or importing ceases, or for seven years, whichever is shorter.

(b) Monitoring records maintained pursuant to paragraph (a) of this section must contain:

(1) The method of analysis.

(2) The results of the analysis, including data from the Quality Assurance Plan.

(3) Description of the sample matrix.

(4) The name of the analyst or analysts.

(5) The date and time of the analysis.

(6) Numbers for the lots from which the samples are taken.

(Sec. 6, Pub. L. 94-469, 90 Stat. 2020 (15 U.S.C. 2605) [49 FR 28193, July 10, 1984, as amended at 58 FR 34205, June 23, 1993]

\section{Subpart K-PCB Waste Disposal Records and Reports}

Source: 54 FR 52752, Dec. 21, 1989, unless otherwise noted.

\section{\$761.202 EPA identification numbers.}

(a) General. Any generator, commercial storer, transporter, or disposer of PCB waste who is required to have an EPA identification number under this subpart must notify EPA of his/her PCB waste handling activities, using the notification procedures and form described in $\$ 761.205$. EPA will confirm the EPA identification number of facilities already assigned one, and will assign an EPA identification number to facilities that do not have one.

(b) Prohibitions. After June 4, 1990 :

(1) A generator of PCB waste shall not: 
(i) Process, store, dispose of, transport, or offer for transportation PCB waste without having received an EPA identification number from the Agency. A generator of PCB waste who is exempted from notification under $\$ 761.205(\mathrm{c})(1)$ or who notifies EPA in a timely manner under $\$ 761.205(\mathrm{c})(2)(\mathrm{i})$, but has not yet received a unique identification number, shall be regarded as having received from EPA the identification number " $40 \mathrm{CFR}$ PART 761."

(ii) Offer the PCB waste to transporters, disposers, or commercial storers of PCB waste who have not received an EPA identification number.

(2) A transporter of PCB waste shall not:

(i) Transport PCB waste without having received an EPA identification number from EPA.

(ii) Deliver PCB waste to transporters, disposers, or commercial storers of PCB waste that have not received an EPA identification number.

(3) A commercial storer of PCB waste shall not accept any PCB waste for storage without having received an EPA identification number from EPA.

(4) A disposer of PCB waste shall not accept any PCB waste for disposal without having received an EPA identification number from EPA. A disposer of PCB waste who owns more than one disposal facility or mobile treatment unit shall not accept waste unless the disposer has received an EPA identification number for each facility or mobile unit.

(c) PCB waste handled prior to effective date of this subpart. Generators (other than generators exempt from notification under $\$ 761.205(\mathrm{c})(1))$, commercial storers, transporters, and disposers of PCB waste who are required to have EPA identification numbers under this subpart, and who were engaged in PCB waste handling activities on or prior to February 5, 1990, are not subject to the prohibitions of paragraph (b) of this section if they have applied for an EPA identification number in accordance with the applicable notification procedures of \$761.205. Such persons shall use the EPA identification number "40 CFR PART 761," or a number assigned to the persons by EPA or a State under RCRA, until EPA issues to such persons a specific identification number under $\$ 761.205$ (a), (b), or (c).

(d) PCB waste first handled after effective date of this subpart. Generators (other than generators exempt from notification under $\$ 761.205(\mathrm{c})(1))$, commercial storers, transporters, and disposers of PCB waste who are required to have EPA identification numbers under this subpart, and who first engage in PCB waste activities after February 5,1990 , are subject to the prohibitions in paragraph (b) of this section.

\section{\$761.205 Notification of PCB waste activity (EPA Form 7710-53).}

(a)(1) All commercial storers, transporters, and disposers of PCB waste who were engaged in PCB waste handling activities on or prior to February 5, 1990 shall notify EPA of their PCB waste activities by filing EPA Form 7710-53 with EPA by no later than April 4, 1990. Upon receiving the notification form, EPA will assign an EPA identification number to each entity that notifies.

(2) All generators (other than generators exempt from notification under paragraph (c)(1) of this section), commercial storers, transporters, and disposers of PCB waste who first engage in PCB waste handling activities after February 5, 1990, shall notify EPA of their PCB waste activities by filing EPA Form 7710-53 with EPA prior to engaging in PCB waste handling activities.

(3) Any person required to notify EPA under this section shall file with EPA Form 7710-53. Copies of EPA Form 7710-53 are available from the Operations Branch (TS-798), Office of Toxic Substances, Environmental Protection Agency, $401 \mathrm{M} \mathrm{St}$. SW, Washington, DC 20460. Descriptive information and instructions for filling in the form are included in paragraphs (a)(4) (i) through (vii) of this section.

(4) All of the following information shall be provided to EPA on Form 7710-53:

(i) The name of the facility, and the name of the owner or operator of the facility.

(ii) EPA identification number, if any, previously issued to the facility.

(iii) The facility's mailing address.

(iv) The location of the facility.

(v) The facility's installation contact and telephone number.

(vi) The type of PCB waste activity engaged in at the facility.

(vii) Signature of the signer of the certification statement, typed or printed name and official title of signer, and date signed.

(viii) EPA has determined that the information in paragraphs (a)(4)(i) through 
(a)(4)(vii) of this section shall not be treated as confidential business information. This information will be disclosed to the public without further notice to the submitter unless the submitter provides a written justification (submitted with the notification form) which demonstrates extraordinary reasons why the information should be entitled to confidential treatment.

(b) Generators (other than those generators exempt from notification under paragraph (c)(1) of this section), commercial storers, transporters, and disposers of PCB waste who have previously notified EPA or a State of hazardous waste activities under RCRA shall notify EPA of their PCB waste activities under this part by filing EPA Form 7710-53 with EPA by no later than April 4, 1990. The notification shall include the EPA identification number previously issued by EPA or the State and upon receipt of the notification, EPA shall verify and authorize the use of the previously issued identification number for PCB waste activities.

(c)(1) Generators of PCB waste need not notify EPA and receive unique EPA identification numbers under this section, unless their PCB waste activities are described in paragraph (c)(2) of this section. Generators exempted from notifying EPA under this paragraph shall use the generic identification number " 40 CFR PART 761" on the manifests, records, and reports which they shall prepare under this subpart, unless such generators elect to use a unique EPA identification number previously assigned to them under RCRA by EPA or a State.

(2) Generators of PCB waste who use, own, service, or process PCBs or PCB Items shall notify EPA of their PCB waste activities only if they own or operate PCB storage facilities subject to the storage requirements of $\$ 761.65$ (b) or (c)(7). Such generators shall notify EPA in the following manner:

(i) Generators storing PCB waste subject to the storage requirements of $\$ 761.65(\mathrm{~b})$ or (c)(7) shall notify EPA by filing EPA Form 7710-53 with EPA by no later than April 4, 1990.

(ii) Generators who desire to commence storage of PCB waste after February 5, 1990 shall notify EPA and receive an EPA identification number before they may commence storage of PCBs at their facilities established under $\$ 761.65$ (b) or (c)(7).

(iii) A separate notification shall be submitted to EPA for each PCB storage facility owned or operated by generators of PCB waste. Upon receiving these notifications, EPA will assign generators unique EPA identification numbers for each storage facility notifying EPA under this section.

(d) Persons required to notify under this section shall file EPA Form 7710-53 with EPA by mailing the form to the following address: Chief, Operations Branch (TS-798), Office of Toxic Substances, Environmental Protection Agency, Rm. NE-117, 401 M St., SW, Washington, DC 20460.

(e) The requirements under this section to notify EPA and obtain EPA identification numbers shall in no case excuse compliance by any person subject to the 1-year limit on storage prior to disposal under $\$ 761.65(\mathrm{a})$.

[54 FR 52752, Dec. 21, 1989, as amended at $58 \mathrm{FR}$ 15809, Mar. 24, 1993; 58 FR 34205, June 23, 1993]

\section{\$761.207 The manifest-general requirements.}

(a) A generator who relinquishes control over PCB wastes by transporting, or offering for transport by his own vehicle or by a vehicle owned by another person, PCB waste for commercial off-site storage or off-site disposal shall prepare a manifest on EPA Form 8700-22, and if necessary, a continuation sheet. The generator shall specify:

(1) For each bulk load of PCBs, the identity of the PCB waste, the earliest date of removal from service for disposal, and the weight in kilograms of the PCB waste.

(2) For each PCB Article Container or PCB Container, the unique identifying number, type of PCB waste (e.g., soil, debris, small capacitors), earliest date of removal from service for disposal, and weight in kilograms of the PCB waste contained.

(3) For each PCB Article not in a PCB Container or PCB Article Container, the serial number if available, or other identification if there is no serial number, the date of removal from service for disposal, and weight in kilograms of the PCB waste in each PCB Article.

(b) EPA does not maintain supplies of printed copies of Form $8700-22$ for public use, although printed copies of the manifest may be available from State offices. Camera-ready copies of the form are available for printing purposes from State offices, EPA Regional Offices, and EPA Headquarters. 
(c) If the State to which the shipment is manifested (i.e., consignment State) supplies the manifest and requires its use, then the generator must use that manifest.

(d) If the consignment State does not supply the manifest, but the State in which the generator is located (i.e., generator State) supplies the manifest and requires its use, then the generator must use that State's manifest.

(e) If both the consignment State and the generator State supply manifests and require their use, the generator must use the consignment State's manifest.

(f) If neither the generator State nor the consignment State supplies the manifest, the generator may obtain the manifest from any source.

(g) A generator shall designate on the manifest one off-site commercial storage or disposal facility approved under this part for the commercial storage or disposal of the PCBs and PCB Items described on the manifest.

(h) If the transporter is unable to deliver the PCB waste to the designated disposer or commercial storer, the transporter must contact the generator of the PCB waste for instructions. The generator shall either designate another approved disposer or commercial storer, or instruct the transporter to return the PCB waste back to the generator.

(i) The manifest which accompanies the PCB waste shall consist of at a minimum the number of copies required to provide the generator, the initial transporter, each subsequent transporter, and the owner or operator of the designated commercial storage or disposal facility with one legible copy each for their records, and one additional copy to be returned to the generator by the owner or operator of the first designated commercial storage or disposal facility.

(j) The requirements of this section apply only to PCB wastes as defined in \$761.3. This includes PCB wastes with PCB concentrations below $50 \mathrm{ppm}$ where the $\mathrm{PCB}$ concentration below $50 \mathrm{ppm}$ was the result of dilution; these PCB wastes are required, under $\$ 761.1(b)$, to be managed as if they contained PCB concentrations greater than 50 $\mathrm{ppm}$. An example of such a PCB waste is spill cleanup material containing less than $50 \mathrm{ppm}$ PCBs when the spill involved material containing greater than $50 \mathrm{ppm}$.

$\$ 761.208$ Use of the manifest.

(a)(1) The generator of PCB waste shall: (i) Sign the manifest certification by hand.

(ii) Obtain the handwritten signature of the initial transporter and date of acceptance on the manifest.

(iii) Retain one copy among its records in accordance with $\$ 761.209$ (a).

(iv) Give to the transporter the remaining copies of the manifest that will accompany the shipment of PCB waste.

(2) For bulk shipments of PCB waste within the United States transported solely by water, the generator shall send three copies of the manifest dated and signed in accordance with this section directly to the owner or operator of the designated commercial storage or disposal facility. Copies of the manifest are not required for each transporter.

(3) For rail shipments of PCB waste within the United States which originate at the site of generation, the generator shall send at least three copies of the manifest dated and signed in accordance with this section to:

(i) The next non-rail transporter, if any.

(ii) The designated commercial storage or disposal facility if transported solely by rail.

(4) When a generator has employed an independent transporter to transport the PCB waste to a commercial storer or disposer, the generator shall confirm by telephone, or by other means of confirmation agreed to by both parties, that the commercial storer or disposer actually received the manifested waste. The generator shall confirm receipt of the waste by close of business the day after he receives the manifest hand-signed by the commercial storer or disposer, in accordance with paragraph (c)(1)(iv) of this section. If the generator has not received the hand-signed manifest within 35 days after the independent transporter accepted the PCB waste, the generator shall telephone, or communicate with by some other agreed-upon means, the disposer or commercial storer to determine whether the PCB waste has actually been received. If the PCB waste has not been received, the generator shall contact the independent transporter to determine the disposition of the PCB waste. If the generator has not received a hand-signed manifest from an EPA-approved facility within 10 days from the date of the telephone call or other agreed upon means of communication, to the independent transporter, the generator shall submit an exception report to the EPA Regional Administrator for the Region in which the generator is located, as specified in $\$ 761.215$. The generator shall retain a written 
record of all telephone or other confirmations to be included in the annual document $\log$, in accordance with $\$ 761.180$.

(b)(1) A transporter shall not accept PCB waste from a generator unless it is accompanied by a manifest signed by the generator in accordance with paragraph (a)(1) of this section, except that a manifest is not required if any one of the following conditions exists:

(i) The shipment of PCB waste consists solely of PCB wastes with PCB concentrations below $50 \mathrm{ppm}$, unless the $\mathrm{PCB}$ concentration below $50 \mathrm{ppm}$ was the result of dilution, in which case $\$ 761.1(\mathrm{~b})$ requires that the waste be managed as if it contained PCBs at the concentration prior to dilution.

(ii) The PCB waste is accepted by the transporter for transport only to a storage or disposal facility owned or operated by the generator of the PCB waste.

(2) Before transporting the $\mathrm{PCB}$ waste, the transporter shall sign and date the manifest acknowledging acceptance of the PCB waste from the generator. The transporter shall return a signed copy to the generator before leaving the generator's facility.

(3) The transporter shall ensure that the manifest accompanies the PCB waste.

(4) A transporter who delivers PCB waste to another transporter, or to the designated commercial storer or disposer of PCB waste, shall:

(i) Obtain the date of delivery and the handwritten signature of the subsequent transporter of PCB waste, or of the owner or operator of the designated commercial storage or disposal facility on the manifest.

(ii) Retain one copy of the manifest in accordance with \$761.209(b).

(iii) Give the remaining copies of the manifest to the accepting transporter of $\mathrm{PCB}$ waste, or to the designated commercial storage or disposal facility.

(5) The requirements of paragraphs (b) (3) and (4) of this section shall not apply to transporters of bulk shipments by water if all of the following conditions are met:

(i) The PCB waste is delivered by water (bulk shipment) to the designated commercial storage or disposal facility.

(ii) A shipping paper containing all the information required on the manifest (excluding EPA identification number, generator certification, and signatures) accompanies the PCB waste. (iii) The transporter delivering the $\mathrm{PCB}$ waste obtains the date of delivery and handwritten signature of the owner or operator of the designated commercial storage or disposal facility on either the manifest or the shipping paper.

(iv) The person delivering the PCB waste to the initial water (bulk shipment) transporter obtains the date of delivery and signature of the water (bulk shipment) transporter on the manifest and forwards it to the designated facility.

(v) A copy of the shipping paper or manifest is retained by each water (bulk shipment) transporter in accordance with $\$ 761.209$ (b).

(6) For shipments involving rail transportation, the requirements of paragraphs (b) (3) and (b)(4) of this section shall not apply. Instead, the requirements described at $\$ 263.20$ (f) of this chapter for the rail transportation of hazardous waste apply to such shipments. The rail transporter shall retain one copy of the manifest or rail shipping paper in accordance with $\S 761.209$ (b).

(7) The transporter shall deliver the entire quantity of PCB waste accepted from a generator or transporter to either of the following destinations:

(i) The designated commercial storage or disposal facility listed on the manifest.

(ii) The next designated transporter of PCB waste.

(8) If the PCB waste cannot be delivered in accordance with paragraph (b)(7) of this section, the transporter shall contact the generator for further directions and shall revise the manifest and/or return the PCB waste according to the generator's instructions.

(9) No provision of this section shall be construed to affect or limit the applicability of any requirement applicable to transporters of PCB waste under regulations issued by the Department of Transportation (DOT) and set forth at 49 CFR part 171.

(c)(1) If a commercial storage or disposal facility receives an off-site shipment of PCB waste accompanied by a manifest, the owner or operator, or his agent, shall:

(i) Sign and date each copy of the manifest to certify that the PCB waste covered by the manifest was received.

(ii) Note any significant discrepancies in the manifest (as defined in $\$ 761.210(a)(1)$ ) on each copy of the manifest. 
(iii) Immediately give the transporter at least one copy of the signed manifest.

(iv) Within 30 days after the delivery, send a copy of the manifest to the generator.

(v) Retain a copy of each manifest among the facility's records in accordance with \$761.209(d).

(2) If a commercial storage or disposal facility receives PCB waste from a rail or water (bulk shipment) transporter accompanied by a shipping paper containing all the information required on the manifest except the EPA identification numbers, generator's certification, and signatures, the owner or operator, or his agent, shall:

(i) Sign and date each copy of the manifest or shipping paper to certify that the PCB waste covered by the manifest or shipping paper was received.

(ii) Note any significant discrepancies in the manifest or shipping paper on each copy of the manifest or shipping paper.

(iii) Immediately give the rail or water transporter at least one copy of the manifest or shipping paper, if applicable.

(iv) Within 30 days after the delivery, send a copy of the signed and dated manifest to the generator; however, if the manifest has not been received within 30 days after delivery, the owner or operator shall send a copy of the shipping paper signed and dated to the generator.

(v) Retain at the commercial storage or disposal facility a copy of the manifest and shipping paper, if signed in lieu of the manifest, in accordance with $\$ 761.209$ (d).

(3) Whenever an off-site shipment of PCB waste is initiated from a commercial storage or disposal facility, the owner or operator of the commercial storage or disposal facility shall comply with the manifest requirements that apply to generators of PCB waste.

\section{$\$ 761.209$ Retention of manifest records.}

(a) A generator of PCB waste shall keep a copy of each manifest signed in accordance with $\$ 761.208(a)(1)$ until the generator receives a signed copy from the designated commercial storage or disposal facility which received the PCB waste. The copy signed by the commercial storer or disposer shall be retained for at least 3 years from the date the PCB waste was accepted by the initial transporter. A generator subject to annual document requirements under $\$ 761.180$ shall retain copies of each manifest for the period required by $\$ 761.180(a)$. (b)(1) A transporter of PCB waste shall keep a copy of the manifest signed by the generator, transporter, and the next designated transporter, if applicable, or the owner or operator of the designated commercial storage or disposal facility. This copy shall be retained for a period of at least 3 years from the date the PCB waste was accepted by the initial transporter.

(2) For shipments of PCB waste delivered to the designated commercial storage or disposal facility by water (bulk shipment), each water (bulk shipment) transporter shall retain a copy of the shipping paper described in $\$ 761.208(b)(5)($ ii) for a period of at least 3 years from the date the PCB waste was accepted by the initial transporter.

(3) For shipments of PCB waste by rail within the United States:

(i) The initial rail transporter shall keep a copy of the manifest and the shipping paper required to accompany the PCB waste for a period of at least 3 years from the date the PCB waste was accepted by the initial transporter.

(ii) The final rail transporter shall keep a copy of the signed manifest, or the required shipping paper if signed by the designated facility in lieu of the manifest, for a period of at least 3 years from the date the PCB waste was accepted by the initial transporter.

(c) The owner or operator of a PCB commercial storage or disposal facility that receives off-site shipments of PCB waste shall retain at the facility for at least 3 years a copy of each manifest or shipping paper that the owner or operator signs in accordance with $\$ 761.208(c)(1)$ or (c)(3).

(d) The periods of record retention required by this section shall be extended automatically during the course of any outstanding enforcement action regarding the regulated activity.

[54 FR 52752, Dec. 21, 1989, as amended at 58 FR 34205, June 23, 1993]

\section{\$761.210 Manifest discrepancies.}

(a) Manifest discrepancies are differences between the quantity or type of PCB waste designated on the manifest or shipping paper and the quantity or type of $\mathrm{PCB}$ waste actually delivered to and received by a designated facility.

(1) Significant discrepancies in quantity are:

(i) Variations greater than 10 percent in weight of $\mathrm{PCB}$ waste in containers. 
(ii) Any variation in piece count, such as a discrepancy of one PCB Transformer or PCB Container or PCB Article Container in a truckload.

(2) Significant discrepancies in type of PCB waste are obvious differences which may be discovered by inspection or waste analysis, such as the substitution of solids for liquids or the substitution of high concentration PCBs (above $500 \mathrm{ppm}$ ) with lower concentration materials.

(b) Upon discovering a significant discrepancy, the owner or operator of the designated commercial storage or disposal facility shall attempt to reconcile the discrepancy with the waste generator or transporter. If the discrepancy is not resolved within 15 days after receiving the PCB waste, such owner or operator shall immediately submit to the Regional Administrator for the Region in which the designated facility is located a letter describing the discrepancy and attempts to reconcile it, and a copy of the manifest or shipping paper at issue.

[54 FR 52752, Dec. 21, 1989, as amended at 58 FR 34205, June 23, 1993]

\section{\$761.211 Unmanifested waste report.}

(a) After April 4, 1990, if a PCB commercial storage or disposal facility receives any shipment of PCB waste from an off-site source without an accompanying manifest or shipping paper (where required in place of a manifest), and any part of the shipment consists of any PCB waste regulated for disposal, then the owner or operator of the commercial storage or disposal facility shall attempt to contact the generator, using information supplied by the transporter, to obtain a manifest or to return the PCB waste.

(b) If the owner or operator of the commercial storage or disposal facility cannot contact the generator of the PCB waste, he shall notify the Regional Administrator of the EPA region in which his facility is located of the unmanifested PCB waste so that the Regional Administrator can determine whether further actions are required before the owner or operator may store or dispose of the unmanifested PCB waste.

(c) Within 15 days after receiving the unmanifested PCB waste, the owner or operator shall prepare and submit a report to the Regional Administrator for the Region in which the commercial storage or disposal facility is located and to the Regional
Administrator for the Region in which the PCB waste originated, if known. The report may be submitted on EPA Form 8700-13B, or by a written letter designated "Unmanifested Waste Report." The report shall include the following information:

(1) The EPA identification number, name, and address of the PCB commercial storage or disposal facility.

(2) The date the commercial storage or disposal facility received the unmanifested PCB waste.

(3) The EPA identification number, name, and address of the generator and transporter, if available.

(4) A description of the type and quantity of the unmanifested $\mathrm{PCB}$ waste received at the facility.

(5) A brief explanation of why the waste was unmanifested, if known.

(6) The disposition made of the unmanifested waste by the commercial storage or disposal facility, including:

(i) If the waste was stored or disposed by that facility, was the generator identified and was a manifest subsequently supplied.

(ii) If the waste was sent back to the generator, why and when.

[54 FR 52752, Dec. 21, 1989, as amended at 58 FR 34205, June 23, 1993]

\section{\$761.215 Exception reporting.}

(a) A generator of $\mathrm{PCB}$ waste, who does not receive a copy of the manifest with the handwritten signature of the owner or operator of the designated PCB commercial storage or disposal facility within 35 days of the date the waste was accepted by the initial transporter, shall immediately contact the transporter and/or the owner or operator of the designated facility to determine the status of the PCB waste.

(b) A generator of PCB waste shall submit an Exception Report to the Regional Administrator for the Region in which the generator is located if the generator has not received a copy of the manifest with the handwritten signature of the owner or operator of the designated facility within 45 days of the date the waste was accepted by the initial transporter. The Exception Report shall include the following:

(1) A legible copy of the manifest for which the generator does not have confirmation of delivery.

(2) A cover letter signed by the generator or his authorized representative explaining 
the efforts taken to locate the PCB waste and the results of those efforts.

(c) A disposer of PCB waste shall submit a One-year Exception Report to the Regional Administrator for the Region in which the disposal facility is located whenever the following occurs:

(1) The disposal facility receives PCBs or PCB Items on a date more than 9 months from the date the PCBs or PCB Items were removed from service for disposal, as indicated on the manifest or continuation sheet; and

(2) Because of contractual commitments or other factors affecting the facility's disposal capacity, the disposer of PCB waste could not dispose of the affected PCBs or PCB Items within 1 year of the date of removal from service for disposal.

(d) A generator or commercial storer of PCB waste who manifests PCBs or PCB Items to a disposer of $\mathrm{PCB}$ waste shall submit a One-year Exception Report to the Regional Administrator for the Region in which the generator or commercial storer is located whenever the following occurs:

(1) The generator or commercial storer transferred the PCBs or PCB Items to the disposer of PCB waste on a date within 9 months from the date of removal from service for disposal of the affected PCBs or PCB Items, as indicated on the manifest or continuation sheet; and

(2) The generator or commercial storer either has not received within 13 months from the date of removal from service for disposal a Certificate of Disposal confirming the disposal of the affected PCBs or PCB Items, or the generator or commercial storer receives a Certificate of Disposal confirming disposal of the affected PCBs or PCB Items on a date more than 1 year after the date of removal from service.

(e) The One-year Exception Report shall include:

(1) A legible copy of any manifest or other written communication relevant to the transfer and disposal of the affected PCBs or PCB Items.

(2) A cover letter signed by the submitter or an authorized representative explaining:

(i) The date(s) when the PCBs or PCB Items were removed from service for disposal.

(ii) The date(s) when the PCBs or PCB Items were received by the submitter of the report, if applicable. (iii) The date(s) when the affected PCBs or PCB Items were transferred to a designated disposal facility.

(iv) The identity of the transporters, commercial storers, or disposers known to be involved with the transaction.

(v) The reason, if known, for the delay in bringing about the disposal of the affected PCBs or PCB Items within 1 year from the date of removal from service for disposal.

[54 FR 52752, Dec. 21, 1989, as amended at 55 FR 26205, June 27, 1990; 58 FR 34205, June 23, 1993]

\section{$\$ 761.218$ Certificate of disposal.}

(a) For each shipment of manifested PCB waste that the owner or operator of a disposal facility accepts by signing the manifest, the owner or operator of the disposal facility shall prepare a Certificate of Disposal for the PCBs and PCB Items disposed of at the facility, which shall include:

(1) The identity of the disposal facility, by name, address, and EPA identification number.

(2) The identity of the PCB waste affected by the Certificate of Disposal including reference to the manifest number for the shipment.

(3) A statement certifying the fact of disposal of the identified PCB waste, including the date(s) of disposal, and identifying the disposal process used.

(4) A certification as defined in $\$ 761.3$.

(b) The Certificate of Disposal shall be sent to the generator identified on the manifest which accompanied the shipment of PCB waste within 30 days of the date that disposal of the PCB waste identified on the manifest was completed.

(c) The disposal facility shall keep a copy of each Certificate of Disposal among the records that it retains under $\$ 761.180$ (b).

(d)(1) Generators of PCB waste shall keep a copy of each Certificate of Disposal that they receive from disposers of PCB waste among the records they retain under $\$ 761.180(a)$.

(2) Commercial storers of PCB waste shall keep a copy of each Certificate of Disposal that they receive from disposers of $P C B$ waste among the records the retain under $\$ 761.180(b)$. 
December 1, 1994

Revision 7

\section{BLANK PAGE}


40 CFR 792 


\section{PART 792-GOOD LABORATORY} PRACTICE STANDARDS

\section{Subpart A-General Provisions}

Sec.

792.1

792.3

792.10

792.12

792.15

792.17

\section{Subpart B-Organization and Personnel}

792.29

792.31

792.33

792.35

792.41

792.43

792.45

792.47

792.49

792.51

792.61

792.63

Scope.

Definitions. under grants and contracts.

Statement of compliance or non-compliance.

Inspection of a testing facility. Effects of non-compliance.

\section{Personnel.}

Testing facility management.

Study director.

Quality assurance unit.

\section{Subpart C-Facilities}

\section{General.}

Test system care facilities.

Test system supply facilities. Facilities for handling test, Laboratory operation areas. Specimen and data storage facilities.

\section{Subpart D-Equipment}

\section{Equipment design.}

Maintenance and calibration of
Applicability to studies performed control, and reference substances. equipment.

\section{Subpart E-Testing Facilities Operation}

792.81

792.83

Standard operating procedures.

792.90

Reagents and solutions.

Animal and other test system care.

\section{Subpart F-Test, Control, and Reference Substances}

792.105 Test, control, and reference substance characterization.

792.107 Test, control, and reference substance handling.

792.113 Mixtures of substances with carriers.

\section{Subpart G-Protocol for and Conduct of a Study}

792.120 Protocol.

792.130 Conduct of a study.
792.135 Physical and chemical

characterization studies.

Subparts H and I--[Reserved]

Subpart J-Records and Reports

792.185 Reporting of study results.

792.190 Storage and retrieval of records and data.

792.195 Retention of records.

Authority: 15 U.S.C. 2603.

\section{Subpart A-General Provisions}

\$792.1 Scope.

(a) This part prescribes good laboratory practices for conducting studies relating to health effects, environmental effects, and chemical fate testing. This part is intended to ensure the quality and integrity of data submitted pursuant to testing consent agreements and test rules issued under $\S 4$ of the Toxic Substances Control Act (TSCA) (Pub. L. 94-469, 90 Stat. 2006, 15 U.S.C. 2603 et seq.).

(b) This part applies to any study described by paragraph (a) of this section which any person conducts, initiates, or supports on or after September 18, 1989.

(c) It is EPA's policy that all data developed under $\S 5$ of TSCA be in accordance with provisions of this part. If data are not developed in accordance with the provisions of this part, EPA will consider such data insufficient to evaluate the health and environmental effects of the chemical substances unless the submitter provides additional information demonstrating that the data are reliable and adequate.

\section{\$792.3 Definitions.}

As used in this part the following terms shall have the meanings specified:

"Batch" means a specific quantity or lot of a test, control, or reference substance that has been characterized according to $\S 792.105$ (a).

"Carrier" means any material, including but not limited to, feed, water, soil, and nutrient media, with which the test substance is combined for administration to a test system.

"Control" substance means any chemical substance or mixture, or any other material other than a test substance, feed, or water, that is administered to the test system in the course of a study for the purpose of establishing a 
basis for comparison with the test substance for chemical or biologicaI measurements.

"EPA" means the U.S. Environmental Protection Agency.

"Experimental start date" means the first date the test substance is applied to the test system.

"Experimental termination date" means the last date on which data are collected directly from the study.

"FDA" means the U.S. Food and Drug Administration.

"Person" includes an individual, partnership, corporation, association, scientific or academic establishment, government agency, or organizational unit thereof, and any other legal entity.

"Quality assurance unit" means any person or organizational element, except the study director, designated by testing facility management to perform the duties relating to quality assurance of the studies.

"Raw data" means any laboratory worksheets, records, memoranda, notes, or exact copies thereof, that are the result of original observations and activities of a study and are necessary for the reconstruction and evaluation of the report of that study. In the event that exact transcripts of raw data have been prepared (e.g., tapes which have been transcribed verbatim, dated, and verified accurate by signature), the exact copy or exact transcript may be substituted for the original source as raw data. "Raw data" may include photographs, microfilm or microfiche copies, computer printouts, magnetic media, including dictated observations, and recorded data from automated instruments.

"Reference substance" means any chemical substance or mixture, or analytical standard, or material other than a test substance, feed, or water, that is administered to or used in analyzing the test system in the course of a study for the purposes of establishing a basis for comparison with the test substance for known chemical or biological measurements.

"Specimen" means any material derived from a test system for examination or analysis.

"Sponsor" means:

(1) A person who initiates and supports, by provision of financial or other resources, a study;

(2) A person who submits a study to the EPA in response to a TSCA $\S 4$ (a) test rule and/or a person who submits a study under a
TSCA $\S 4$ testing consent agreement or a TSCA $\S 5$ rule or order to the extent the agreement, rule or order references this part; or

(3) A testing facility, if it both initiates and actually conducts the study.

"Study" means any experiment at one or more test sites, in which a test substance is studied in a test system under laboratory conditions or in the environment to determine or help predict its effects, metabolism, environmental and chemical fate, persistence, or other characteristics in humans, other living organisms, or media. The term "study" does not include basic exploratory studies carried out to determine whether a test substance or a test method has any potential utility.

"Study completion date" means the date the final report is signed by the study director.

"Study director" means the individual responsible for the overall conduct of a study.

"Study initiation date" means the date the protocol is signed by the study director.

"Test substance" means a substance or mixture administered or added to a test system in a study, which substance or mixture is used to develop data to meet the requirements of a TSCA $\S 4$ (a) test rule and/or is developed under a TSCA $\S 4$ testing consent agreement or $\S 5$ rule or order to the extent the agreement, rule or order references this part.

"Test system" means any animal, plant, microorganism, chemical or physical matrix, including but not limited to, soil or water, or components thereof, to which the test, control, or reference substance is administered or added for study. "Test system" also includes appropriate groups or components of the system not treated with the test, control, or reference substance.

"Testing facility" means a person who actually conducts a study, i.e., actually uses the test substance in a test system. "Testing facility" encompasses only those operational units that are being or have been used to conduct studies.

"TSCA" means the Toxic Substances Control Act (15 U.S.C, 2601 et seq.)

"Vehicle" means any agent which facilitates the mixture, dispersion, or solubilization of a test substance with a carrier. 
$\$ 792.10$

\section{Applicability to studies performed under grants and contracts.}

When a sponsor or other person utilizes the services of a consulting laboratory, contractor, or grantee to perform all or a part of a study to which this part applies, it shall notify the consulting laboratory, contractor, or grantee that the service is, or is part of, a study that must be conducted in compliance with the provisions of this part.

\section{$\$ 792.12$ Statement of compliance or non-compliance.}

Any person who submits to EPA a test required by a testing consent agreement or a test rule issued under $\S 4$ of TSCA shall include in the submission a true and correct statement, signed by the sponsor and the study director, of one of the following types:

(a) A statement that the study was conducted in accordance with this part; or

(b) A statement describing in detail all differences between the practices used in the study and those required by this part; or

(c) A statement that the person was not a sponsor of the study, did not conduct the study, and does not know whether the study was conducted in accordance with this part.

\section{$\$ 792.15$ Inspection of a testing facility.}

(a) A testing facility shall permit an authorized employee or duly designated representative of EPA or FDA, at reasonable times and in a reasonable manner, to inspect the facility and to inspect (and in the case of records also to copy) all records and specimens required to be maintained regarding studies to which this part applies. The records inspection and copying requirements shall not apply to quality assurance unit records of findings and problems, or to actions recommended and taken, except the EPA may seek production of these records in litigation or formal adjudicatory hearings.

(b) EPA will not consider reliable for purposes of showing that a chemical substance or mixture does not present a risk of injury to health or the environment any data developed by a testing facility or sponsor that refuses to permit inspection in accordance with this part. The determination that a study will not be considered reliable does not, however, relieve the sponsor of a required test of any obligation under any applicable statute or regulation to submit the results of the study to EPA. (c) Since a testing facility is a place where chemicals are stored or held, it is subject to inspection under $\S 11$ of TSCA.

\section{\$792.17 Effects of non-compliance.}

(a) The sponsor or any other person who is conducting or has conducted a test to fulfill the requirements of a testing consent agreement or a test rule issued under $\S 4$ of TSCA will be in violation of $\S 15$ of TSCA if:

(1) The test is not being or was not conducted in accordance with any requirement of this part;

(2) Data or information submitted to EPA under this part (including the statement required by $\S 792.12$ ) include information or data that are false or misleading, contain significant omissions, or otherwise do not fulfill the requirements of this part; or

(3) Entry in accordance with $\$ 792.15$ for the purpose of auditing test data or inspecting test facilities is denied. Persons who violate the provisions of this part may be subject to civil or criminal penalties under $\S 16$ of TSCA, legal action in United States district court under $\S 17$ of TSCA, or criminal prosecution under 18 U.S.C. 2 or 1001.

(b) EPA, at its discretion, may not consider reliable for purposes of showing that a chemical substance or mixture does not present a risk of injury to health or the environment any study which was not conducted in accordance with this part. EPA, at its discretion, may rely upon such studies for purposes of showing adverse effects. The determination that a study will not be considered reliable does not, however, relieve the sponsor of a required test of the obligation under any applicable statute or regulation to submit the results of the study to EPA.

(c) If data submitted to fulfill a requirement of a testing consent agreement or a test rule issued under $\S 4$ of TSCA are not developed in accordance with this part, EPA may determine that the sponsor has not fulfilled its obligations under $\S 4$ of TSCA and may require the sponsor to develop data in accordance with the requirements of this part in order to satisfy such obligations.

\section{Subpart B-Organization and Personnel}

\section{\$792.29 Personnel.}

(a) Each individual engaged in the conduct of or responsible for the supervision of a study shall have education, training, and experience, or combination thereof, to enable 
that individual to perform the assigned functions.

(b) Each testing facility shall maintain a current summary of training and experience and job description for each individual engaged in or supervising the conduct of a study.

(c) There shall be a sufficient number of personnel for the timely and proper conduct of the study according to the protocol.

(d) Personnel shall take necessary personal sanitation and health precautions designed to avoid contamination of test, control, and reference substances and test systems.

(e) Personnel engaged in a study shall wear clothing appropriate for the duties they perform. Such clothing shall be changed as often as necessary to prevent microbiological, radiological, or chemical contamination of test systems and test, control, and reference substances.

(f) Any individual found at any time to have an illness that may adversely affect the quality and integrity of the study shall be excluded from direct contact with test systems, test, control, and reference substances and any other operation or function that may adversely affect the study until the condition is corrected. All personnel shall be instructed to report to their immediate supervisors any health or medical conditions that may reasonably be considered to have an adverse effect on a study.

\section{\$792.31 Testing facility management.}

For each study, testing facility management shall:

(a) Designate a study director as described in $\$ 792.33$ before the study is initiated.

(b) Replace the study director promptly if it becomes necessary to do so during the conduct of a study.

(c) Assure that there is a quality assurance unit as described in $\$ 792.35$.

(d) Assure that test, control, and reference substances or mixtures have been appropriately tested for identity, strength, purity, stability, and uniformity, as applicable.

(e) Assure that personnel, resources, facilities, equipment, materials and methodologies are available as scheduled.

(f) Assure that personnel clearly understand the functions they are to perform.

(g) Assure that any deviations from these regulations reported by the quality assurance unit are communicated to the study director and corrective actions are taken and documented.

\section{$\$ 792.33$ Study director.}

For each study, a scientist or other professional of appropriate education, training, and experience, or combination thereof, shall be identified as the study director. The study director has overall responsibility for the technical conduct of the study, as well as for the interpretation, analysis, documentation, and reporting of results, and represents the single point of study control. The study director shall assure that:

(a) The protocol, including any change, is approved as provided by $\$ 792.120$ and is followed.

(b) All experimental data, including observations of unanticipated responses of the test system are accurately recorded and verified.

(c) Unforeseen circumstances that may affect the quality and integrity of the study are noted when they occur, and corrective action is taken and documented.

(d) Test systems are as specified in the protocol.

(e) All applicable good laboratory practice regulations are followed.

(f) All raw data, documentation, protocols, specimens, and final reports are transferred to the archives during or at the close of the study.

\section{\$792.35 Quality assurance unit.}

(a) A testing facility shall have a quality assurance unit which shall be responsible for monitoring each study to assure management that the facilities, equipment, personnel, methods, practices, records, and controls are in conformance with the regulations in this part. For any given study, the quality assurance unit shall be entirely separate from and independent of the personnel engaged in the direction and conduct of that study. The quality assurance unit shall conduct inspections and maintain records appropriate to the study.

(b) The quality assurance unit shall:

(1) Maintain a copy of a master schedule sheet of all studies conducted at the testing facility indexed by test substance and containing the test system, nature of study, date study was initiated, current status of each study, identity of the sponsor, and name of the study director. 
(2) Maintain copies of all protocols pertaining to all studies for which the unit is responsible.

(3) Inspect each study at intervals adequate to ensure the integrity of the study and maintain written and properly signed records of each periodic inspection showing the date of the inspection, the study inspected, the phase or segment of the study inspected, the person performing the inspection, findings and problems, action recommended and taken to resolve existing problems, and any scheduled date for re-inspection. Any problems which are likely to affect study integrity found during the course of an inspection shall be brought to the attention of the study director and management immediately.

(4) Periodically submit to management and the study director written status reports on each study, noting any problems and the corrective actions taken.

(5) Determine that no deviations from approved protocols or standard operating procedures were made without proper authorization and documentation.

(6) Review the final study report to assure that such report accurately describes the methods and standard operating procedures, and that the reported results accurately reflect the raw data of the study.

(7) Prepare and sign a statement to be included with the final study report which shall specify the dates inspections were made and findings reported to management and to the study director.

(c) The responsibilities and procedures applicable to the quality assurance unit, the records maintained by the quality assurance unit, and the method of indexing such records shall be in writing and shall be maintained. These items including inspection dates, the study inspected, the phase or segment of the study inspected, and the name of the individual performing the inspection shall be made available for inspection to authorized employees or duly designated representatives of EPA or FDA.

(d) An authorized employee or a duly designated representative of EPA or FDA shall have access to the written procedures established for the inspection and may request testing facility management to certify that inspections are being implemented, performed, documented, and followed up in accordance with this paragraph.

\section{Subpart C-Facilities \\ \$792.41 General.}

Each testing facility shall be of suitable size and construction to facilitate the proper conduct of studies. Testing facilities which are not located within an indoor controlled environment shall be of suitable location to facilitate the proper conduct of studies. Testing facilities shall be designed so that there is a degree of separation that will prevent any function or activity from having an adverse effect on the study.

\section{\$792.43 Test system care facilities.}

(a) A testing facility shall have a sufficient number of animal rooms or other test system areas, as needed, to ensure: proper separation of species or test systems, isolation of individual projects, quarantine or isolation of animals or other test systems, and routine or specialized housing of animals or other test systems.

(1) In tests with plants or aquatic animals, proper separation of species can be accomplished within a room or area by housing them separately in different chambers or aquaria. Separation of species is unnecessary where the protocol specifies the simultaneous exposure of two or more species in the same chamber, aquarium, or housing unit.

(2) Aquatic toxicity tests for individual projects shall be isolated to the extent necessary to prevent cross-contamination of different chemicals used in different tests.

(b) A testing facility shall have a number of animal rooms or other test system areas separate from those described in paragraph (a) of this section to ensure isolation of studies being done with test systems or test, control, and reference substances known to be biohazardous, including volatile substances, aerosols, radioactive materials, and infectious agents.

(c) Separate areas shall be provided, as appropriate, for the diagnosis, treatment, and control of laboratory test system diseases. These areas shall provide effective isolation for the housing of test systems either known or suspected of being diseased, or of being carriers of disease, from other test systems.

(d) Facilities shall have proper provisions for collection and disposal of contaminated water, soil, or other spent materials. When animals are housed, facilities shall exist for the collection and disposal of all animal waste 
and refuse or for safe sanitary storage of waste before removal from the testing facility. Disposal facilities shall be so provided and operated as to minimize vermin infestation, odors, disease hazards, and environmental contamination.

(e) Facilities shall have provisions to regulate environmental conditions (e.g., temperature, humidity, photoperiod) as specified in the protocol.

(f) For marine test organisms, an adequate supply of clean sea water or artificial sea water (prepared from deionized or distilled water and sea salt mixture) shall be available. The ranges of composition shall be as specified in the protocol.

(g) For freshwater organisms, an adequate supply of clean water of the appropriate hardness, $\mathrm{pH}$, and temperature, and which is free of contaminants capable of interfering with the study shall be available as specified in the protocol.

(h) For plants, an adequate supply of soil of the appropriate composition, as specified in the protocol, shall be available as needed.

\section{\$792.45 Test system supply facilities.}

(a) There shall be storage areas, as needed, for feed, nutrients, soils, bedding, supplies, and equipment. Storage areas for feed, nutrients, soils, and bedding shall be separated from areas where the test systems are located and shall be protected against infestation or contamination. Perishable supplies shall be preserved by appropriate means.

(b) When appropriate, plant supply facilities shall be provided. These include:

(1) Facilities, as specified in the protocol, for holding, culturing, and maintaining algae and aquatic plants.

(2) Facilities, as specified in the protocol, for plant growth, including but not limited to, greenhouses, growth chambers, light banks, and fields.

(c) When appropriate, facilities for aquatic animal tests shall be provided. These include but are not limited to aquaria, holding tanks, ponds, and ancillary equipment, as specified in the protocol.

\section{\$792.47 Facilities for handling test, control, and reference substances.}

(a) As necessary to prevent contamination or mixups, there shall be separate areas for:
(1) Receipt and storage of the test, control, and reference substances.

(2) Mixing of the test, control, and reference substances with a carrier, e.g., feed.

(3) Storage of the test, control, and reference substance mixtures.

(b) Storage areas for test, control, and/or reference substance and for test, control, and/or reference mixtures shall be separate from areas housing the test systems and shall be adequate to preserve the identity, strength, purity, and stability of the substances and mixtures.

\section{$\$ 792.49$ Laboratory operation areas.}

Separate laboratory space and other space shall be provided, as needed, for the performance of the routine and specialized procedures required by studies.

\section{$\$ 792.51$ Specimen and data storage facilities.}

Space shall be provided for archives, limited to access by authorized personnel only, for the storage and retrieval of all raw data and specimens from completed studies.

\section{\$792.61 Equipment design.}

Equipment used in the generation, measurement, or assessment of data and equipment used for facility environmental control shall be of appropriate design and adequate capacity to function according to the protocol and shall be suitably located for operation, inspection, cleaning, and maintenance.

\section{\$792.63 Maintenance and calibration of equipment.}

(a) Equipment shall be adequately inspected, cleaned, and maintained. Equipment used for the generation, measurement, or assessment of data shall be adequately tested, calibrated, and/or standardized.

(b) The written standard operating procedures required under $\S 792.81(b)(11)$ shall set forth in sufficient detail the methods, materials, and schedules to be used in the routine inspection, cleaning, maintenance, testing, calibration, and/ or standardization of equipment, and shall specify, when appropriate, remedial action to be taken in the event of failure or malfunction of equipment. The written standard operating procedures 
shall designate the person responsible for the performance of each operation.

(c) Written records shall be maintained of all inspection, maintenance, testing, calibrating, and/or standardizing operations. These records, containing the date of the operation, shall describe whether the maintenance operations were routine and followed the written standard operating procedures. Written records shall be kept of nonroutine repairs performed on equipment as a result of failure and malfunction. Such records shall document the nature of the defect, how and when the defect was discovered, and any remedial action taken in response to the defect.

\section{Subpart E-Testing Facilities Operation}

\section{\$792.81 Standard operating procedures.}

(a) A testing facility shall have standard operating procedures in writing, setting forth study methods that management is satisfied are adequate to insure the quality and integrity of the data generated in the course of a study. All deviations in a study from standard operating procedures shall be authorized by the study director and shall be documented in the raw data. Significant changes in established standard operating procedures shall be properly authorized in writing by management.

(b) Standard operating procedures shall be established for, but not limited to, the following:

(1) Test system room preparation.

(2) Test system care.

(3) Receipt, identification, storage, handling, mixing, and method of sampling of the test, control, and reference substances.

(4) Test system observations.

(5) Laboratory or other tests.

(6) Handling of test systems found moribund or dead during study.

(7) Necropsy of test systems or postmortem examination of test systems.

(8) Collection and identification of specimens.

(9) Histopathology.

(10) Data handling, storage and retrieval.

(11) Maintenance and calibration of equipment.

(12) Transfer, proper placement, and identification of test systems.

(c) Each laboratory or other study area shall have immediately available manuals and standard operating procedures relative to the laboratory or field procedures being performed. Published literature may be used as a supplement to standard operating procedures.

(d) A historical file of standard operating procedures, and all revisions thereof, including the dates of such revisions, shall be maintained.

\section{\$792.83 Reagents and solutions.}

All reagents and solutions in the laboratory areas shall be labeled to indicate identity, titer or concentration, storage requirements, and expiration date. Deteriorated or outdated reagents and solutions shall not be used.

\section{$\$ 792.90 \quad$ Animal and other test system care.}

(a) There shall be standard operating procedures for the housing, feeding, handling, and care of animals and other test systems.

(b) All newly received test systems from outside sources shall be isolated and their health status or appropriateness for the study shall be evaluated. This evaluation shall be in accordance with acceptable veterinary medical practice or scientific methods.

(c) At the initiation of a study, test systems shall be free of any disease or condition that might interfere with the purpose or conduct of the study. If during the course of the study, the test systems contract such a disease or condition, the diseased test systems should be isolated, if necessary. These test systems may be treated for disease or signs of disease provided that such treatment does not interfere with the study. The diagnosis, authorization of treatment, description of treatment, and each date of treatment shall be documented and shall be retained.

(d) Warm-blooded animals, adult reptiles, and adult terrestrial amphibians used in laboratory procedures that require manipulations and observations over an extended period of time, or in studies that require these test systems to be removed from and returned to their test system-housing units for any reason (e.g., cage cleaning, treatment, etc.), shall receive appropriate identification (e.g., tattoo, color code, ear tag, ear punch, etc.). All information needed to specifically identify each test system within the test system-housing unit shall appear on the outside of that unit. Suckling mammals and juvenile birds are excluded from the 
requirement of individual identification unless otherwise specified in the protocol.

(e) Except as specified in paragraph (e)(1) of this section, test systems of different species shall be housed in separate rooms when necessary. Test systems of the same species, but used in different studies, should not ordinarily be housed in the same room when inadvertent exposure to test, control, or reference substances or test system mixup could affect the outcome of either study. If such mixed housing is necessary, adequate differentiation by space and identification shall be made.

(1) Plants, invertebrate animals, aquatic vertebrate animals, and organisms that may be used in multispecies tests need not be housed in separate rooms, provided that they are adequately segregated to avoid mixup and cross contamination.

(2) [Reserved]

(f) Cages, racks, pens, enclosures, aquaria holding tanks, ponds, growth chambers, and other holding, rearing, and breeding areas, and accessory equipment, shall be cleaned and sanitized at appropriate intervals.

(g) Feed, soil, and water used for the test systems shall be analyzed periodically to ensure that contaminants known to be capable of interfering with the study and reasonably expected to be present in such feed, soil, or water are not present at levels above those specified in the protocol. Documentation of such analyses shall be maintained as raw data.

(h) Bedding used in animal cages or pens shall not interfere with the purpose or conduct of the study and shall be changed as often as necessary to keep the animals dry and clean.

(i) If any pest control materials are used, the use shall be documented. Cleaning and pest control materials that interfere with the study shall not be used.

(j) All plant and animal test systems shall be acclimatized to the environmental conditions of the test, prior to their use in a study.

\section{Subpart F-Test, Control, and Reference Substances}

\section{$\$ 792.105$ Test, control, and reference substance characterization.}

(a) The identity, strength, purity, and composition, or other characteristics which will appropriately define the test, control, or reference substance shall be determined for each batch and shall be documented before its use in a study. Methods of synthesis, fabrication, or derivation of the test, control, or reference substance shall be documented by the sponsor or the testing facility, and such location of documentation shall be specified.

(b) When relevant to the conduct of the study the solubility of each test, control, or reference substance shall be determined by the testing facility or the sponsor before the experimental start date. The stability of the test, control or reference substance shall be determined before the experimental start date or concomitantly according to written standard operating procedures, which provide for periodic analysis of each batch.

(c) Each storage container for a test, control, or reference substance shall be labeled by name, chemical abstracts service number (CAS) or code number, batch number, expiration date, if any, and, where appropriate, storage conditions necessary to maintain the identity, strength, purity, and composition of the test, control, or reference substance. Storage containers shall be assigned to a particular test substance for the duration of the study.

(d) For studies of more than 4 weeks experimental duration, reserve samples from each batch of test, control, and reference substances shall be retained for the period of time provided by $\S 792.195$.

(e) The stability of test, control, and reference substances under storage conditions at the test site shall be known for all studies.

\section{\$792.107 Test, control, and reference substance handling.}

Procedures shall be established for a system for the handling of the test, control, and reference substances to ensure that:

(a) There is proper storage.

(b) Distribution is made in a manner designed to preclude the possibility of contamination, deterioration, or damage.

(c) Proper identification is maintained throughout the distribution process.

(d) The receipt and distribution of each batch is documented. Such documentation shall include the date and quantity of each batch distributed or returned.

\section{\$792.113 Mixtures of substances with carriers.}

(a) For each test, control, or reference substance that is mixed with a carrier, tests by appropriate analytical methods shall be conducted: 
(1) To determine the uniformity of the mixture and to determine, periodically, the concentration of the test, control, or reference substance in the mixture.

(2) When relevant to the conduct of the experiment, to determine the solubility of each test, control, or reference substance in the mixture by the testing facility or the sponsor before the experimental start date.

(3) To determine the stability of the test, control or reference substance in the mixture before the experimental start date or concomitantly according to written standard operating procedures, which provide for periodic analysis of each batch.

(b) Where any of the components of the test, control, or reference substance carrier mixture has an expiration date, that date shall be clearly shown on the container. If more than one component has an expiration date, the earliest date shall be shown.

(c) If a vehicle is used to facilitate the mixing of a test substance with a carrier, assurance shall be provided that the vehicle does not interfere with the integrity of the test.

\section{Subpart G-Protocol for and Conduct of a Study}

\section{\$792.120 Protocol.}

(a) Each study shall have an approved written protocol that clearly indicates the objectives and all methods for the conduct of the study. The protocol shall contain but shall not necessarily be limited to the following information:

(1) A descriptive title and statement of the purpose of the study.

(2) Identification of the test, control, and reference substance by name, chemical abstracts service (CAS) number or code number.

(3) The name and address of the sponsor and the name and address of the testing facility at which the study is being conducted.

(4) The proposed experimental start and termination dates.

(5) Justification for selection of the test system.

(6) Where applicable, the number, body weight, sex, source of supply, species, strain, substrain, and age of the test system.

(7) The procedure for identification of the test system.

(8) A description of the experimental design, including methods for the control of bias.
(9) Where applicable, a description and/or identification of the diet used in the study as well as solvents, emulsifiers and/or other materials used to solubilize or suspend the test, control, or reference substances before mixing with the carrier. The description shall include specifications for acceptable levels of contaminants that are reasonably expected to be present in the dietary materials and are known to be capable of interfering with the purpose or conduct of the study if present at levels greater than established by the specifications.

(10) The route of administration and the reason for its choice.

(11) Each dosage level, expressed in milligrams per kilogram of body or test system weight or other appropriate units, of the test, control, or reference substance to be administered and the method and frequency of administration.

(12) The type and frequency of tests, analyses, and measurements to be made.

(13) The records to be maintained.

(14) The date of approval of the protocol by the sponsor and the dated signature of the study director.

(15) A statement of the proposed statistical method.

(b) All changes in or revisions of an approved protocol and the reasons therefor shall be documented, signed by the study director, dated, and maintained with the protocol.

\section{$\$ 792.130$ Conduct of a study.}

(a) The study shall be conducted in accordance with the protocol.

(b) The test systems shall be monitored in conformity with the protocol.

(c) Specimens shall be identified by test system, study, nature, and date of collection. This information shall be located on the specimen container or shall accompany the specimen in a manner that precludes error in the recording and storage of data.

(d) In animal studies where histopathology is required, records of gross findings for a specimen from postmortem observations shall be available to a pathologist when examining that specimen histopathologically.

(e) All data generated during the conduct of a study, except those that are generated by automated data collection systems, shall be recorded directly, promptly, and legibly in ink. All data entries shall be dated on the day of entry and signed or initialed by the person 
entering the data. Any change in entries shall be made so as not to obscure the original entry, shall indicate the reason for such change, and shall be dated and signed or identified at the time of the change. In automated data collection systems, the individual responsible for direct data input shall be identified at the time of data input. Any change in automated data entries shall be made so as not to obscure the original entry, shall indicate the reason for change, shall be dated, and the responsible individual shall be identified.

\section{\$792.135 Physical and chemical characterization studies.}

(a) All provisions of the GLPs shall apply to physical and chemical characterization studies designed to determine stability, solubility, octanol water partition coefficient, volatility, and persistence (such as biodegradation, photodegradation, and chemical degradation studies).

(b). The following GLP standards shall not apply to studies designed to determine physical and chemical characteristics of a test, control, or reference substance:

$\$ 792.31$ (c), (d), and (g)

$\S 792.35$ (b) and (c)

$\S 792.43$

$\S 792.45$

$\S 792.47$

$\S 792.49$

(12)

$\S 792.81(\mathrm{~b})(1),(2),(6)$ through (9), and

$\S 792.90$

$\S 792.105$ (a) through (d)

$\$ 792.113$

$\S 792.120$ (a) (5) through (12), and (15)

$\S 792.185$ (a) (5) through (8), (10), (12), and (14)

$\S 792.195$ (c) and (d)

\section{Subparts $H$ and I-[Reserved]}

\section{Subpart J-Records and Reports}

\section{$\$ 792.185$ Reporting of study results.}

(a) A final report shall be prepared for each study and shall include, but not necessarily be limited to, the following:

(1) Name and address of the facility performing the study and the dates on which the study was initiated and was completed, terminated, or discontinued.

(2) Objectives and procedures stated in the approved protocol, including any changes in the original protocol.
(3) Statistical methods employed for analyzing the data.

(4) The test, control, and reference substances identified by name, chemical abstracts service (CAS) number or code number, strength, purity, and composition, or other appropriate characteristics.

(5) Stability, and when relevant to the conduct of the study, the solubility of the test, control, and reference substances under the conditions of administration.

(6) A description of the methods used.

(7) A description of the test system used. Where applicable, the final report shall include the number of animals or other test organisms used, sex, body weight range, source of supply, species, strain and substrain, age, and procedure used for identification.

(8) A description of the dosage, dosage regimen, route of administration, and duration.

(9) A description of all circumstances that may have affected the quality or integrity of the data.

(10) The name of the study director, the names of other scientists or professionals and the names of all supervisory personnel, involved in the study.

(11) A description of the transformations, calculations, or operations performed on the data, a summary and analysis of the data, and a statement of the conclusions drawn from the analysis.

(12) The signed and dated reports of each of the individual scientists or other professionals involved in the study, including each person who, at the request or direction of the testing facility or sponsor, conducted an analysis or evaluation of data or specimens from the study after data generation was completed.

(13) The locations where all specimens, raw data, and the final report are to be stored.

(14) The statement prepared and signed by the quality assurance unit as described in $\$$ 792.35(b)(7).

(b) The final report shall be signed and dated by the study director.

(c) Corrections or additions to a final report shall be in the form of an amendment by the study director. The amendment shall clearly identify that part of the final report that is being added to or corrected and the reasons for the correction or addition, and shall be signed and dated by the person responsible. Modification of a final report to comply with the submission requirements of EPA does not 
constitute a correction, addition, or amendment to a final report.

(d) A copy of the final report and of any amendment to it shall be maintained by the sponsor and the test facility.

\section{$\$ 792.190$ Storage and retrieval of records and data.}

(a) All raw data, documentation, records, protocols, specimens, and final reports generated as a result of a study shall be retained. Specimens obtained from mutagenicity tests, specimens of soil, water, and plants, and wet specimens of blood, urine, feces, and biologica1 fluids, do not need to be retained after quality assurance verification. Correspondence and other documents relating to interpretation and evaluation of data, other than those documents contained in the final report, also shall be retained.

(b) There shall be archives for orderly storage and expedient retrieval of all raw data, documentation, protocols, specimens, and interim and final reports. Conditions of storage shall minimize deterioration of the documents or specimens in accordance with the requirements for the time period of their retention and the nature of the documents of specimens. A testing facility may contract with commercial archives to provide a repository for all material to be retained. Raw data and specimens may be retained elsewhere provided that the archives have specific reference to those other locations.

(c) An individual shall be identified as responsible for the archives.

(d) Only authorized personnel shall enter the archives.

(e) Material retained or referred to in the archives shall be indexed to permit expedient retrieval.

\section{\$792.195 Retention of records.}

(a) Record retention requirements set forth in this section do not supersede the record retention requirements of any other regulations in this subchapter.

(b)(1) Except as provided in paragraph (c) of this section, documentation records, raw data, and specimens pertaining to a study and required to be retained by this part shall be retained in the archive(s) for a period of at least ten years following the effective date of the applicable final test rule.

(2) In the case of negotiated testing agreements, each agreement will contain a provision that, except as provided in paragraph (c) of this section, documentation records, raw data, and specimens pertaining to a study and required to be retained by this part shall be retained in the archive(s) for a period of at least ten years following the publication date of the acceptance of a negotiated test agreement.

(3) In the case of testing submitted under $\S 5$, except for those items listed in paragraph (c) of this section, documentation records, raw data, and specimens pertaining to a study and required to be retained by this part shall be retained in the archive(s) for a period of at least five years following the date on which the results of the study are submitted to the agency.

(c) Wet specimens, samples of test, control, or reference substances, and specially prepared material which are relatively fragile and differ markedly in stability and quality during storage, shall be retained only as long as the quality of the preparation affords evaluation. Specimens obtained from mutagenicity tests, specimens of soil, water, and plants, and wet specimens of blood, urine, feces, biological fluids, do not need to be retained after quality assurance verification. In no case shall retention be required for longer periods than those set forth in paragraph (b) of this section.

(d) The master schedule sheet, copies of protocols, and records of quality assurance inspections, as required by $\S 792.35$ (c) shall be maintained by the quality assurance unit as an easily accessible system of records for the period of time specified in paragraph (b) of this section.

(e) Summaries of training and experience and job descriptions required to be maintained by $\S 792.29$ (b) may be retained along with all other testing facility employment records for the length of time specified in paragraph (b) of this section.

(f) Records and reports of the maintenance and calibration and inspection of equipment, as required by $\S 792.63$ (b) and (c), shall be retained for the length of time specified in paragraph (b) of this section.

(g) If a facility conducting testing or an archive contracting facility goes out of business, all raw data, documentation, and other material specified in this section shall be transferred to the archives of the sponsor of the study. The EPA shall be notified in writing of such a transfer.

(h) Specimens, samples, or other non-documentary materials need not be 
retained after EPA has notified in writing the sponsor or testing facility holding the materials that retention is no longer required by EPA. Such notification normally will be furnished upon request after EPA or FDA has completed an audit of the particular study to which the materials relate and EPA has concluded that the study was conducted in accordance with this part.

(i) Records required by this part may be retained either as original records or as true copies such as photocopies, microfilm, microfiche, or other accurate reproductions of the original records. 


\section{TOXIC SUBSTANCES CONTROLACT (TSCA) UPDATE}




\section{SECTION 4. TOXIC SUBSTANCES CONTROL ACT (TSCA) UPDATE}

The update section of the TSCA Reference Book generally includes proposed changes to the statute or regulatory program. In addition, policy statements, interagency agreements, and other supplementary material are provided when pertinent.

On November 1, 1993, DOE's Office of Environmental Guidance (EH-23) issued an environmental guidance document, "Guidance on the Management of Polychlorinated Biphenyls (PCBs)," focusing primarily on the requirements established in 40 CFR 761. This document provides a comprehensive framework of the existing federal PCB regulatory requirements for personnel with line management/oversight responsibilities. While it addresses the use of PCB equipment, storage and transport of PCBs, and cleanup of PCB spills, it does not address in detail certain technical requirements under TSCA that do not apply to most DOE facilities, such as requirements for the operation of a TSCA incinerator or chemical waste landfill. DOE Orders that contain requirements pertinent to PCBs are cited as appropriate. For more information regarding federal PCB regulations, in general, or the environmental guidance document, contact Carolyn Thompson Walder of EH-23 at (202) 586-8248.

\section{Proposed EPA Regulatory Changes}

Table 4-1 summarizes proposed changes to the regulatory program as of December 1, 1994. Federal Register citations are provided in the table for more detailed information. 
December 1, 1994

Revision 7

\section{BLANK PAGE}




\section{TABLE 4-1. SUMMARY OF PROPOSED CHANGES TO EPA'S TSCA REGULATORY PROGRAM}

\begin{tabular}{|c|c|c|}
\hline $\begin{array}{c}\text { SUBJECT } \\
\text { Affected CFR } \\
\text { Citations(s) }\end{array}$ & $\begin{array}{c}\text { STATUS }^{\mathbf{a}} \\
\text { DATE } \\
\text { (FR citation) }\end{array}$ & $\begin{array}{l}\text { DESCRIPTIVE } \\
\text { SUMMARY }\end{array}$ \\
\hline $\begin{array}{l}\text { Comprehensive Assessment } \\
\text { Information Rule } \\
40 \text { CFR } 704\end{array}$ & $\begin{array}{l}\text { NPRM } \\
58 \text { FR } 63134 \\
11 / 30 / 93 \\
\text { Regulatory } \\
\text { Agenda } \\
59 \text { FR } 21074 \\
04 / 25 / 94\end{array}$ & $\begin{array}{l}\text { EPA proposed revising the Comprehensive } \\
\text { Assessment Information Rule (CAIR) to } \\
\text { establish exemptions for small and "de } \\
\text { minimis" volumes, refine trade name } \\
\text { reporting requirements, reduce certain } \\
\text { advance substantiation requirements for } \\
\text { Confidential Business Information (CBI) } \\
\text { claims, and define processing activities } \\
\text { using processor subclasses. }\end{array}$ \\
\hline $\begin{array}{l}\text { PCBs Disposal Amendments } \\
40 \text { CFR } 761\end{array}$ & $\begin{array}{l}\text { ANPRM } \\
\text { 56 FR 26738 } \\
\text { 06/10/91 } \\
\text { NOA } \\
\text { 56 FR 26745 } \\
\text { 06/10/91 } \\
\text { Planned NPRM } \\
\text { 59 FR 58225 } \\
\text { 11/14/94 }\end{array}$ & $\begin{array}{l}\text { EPA is considering amending its TSCA } \\
\text { PCB disposal regulations to address (1) } \\
\text { alternative disposal methods to those } \\
\text { currently permitted which do not pose an } \\
\text { unreasonable risk of injury to human } \\
\text { health and the environment, (2) classes of } \\
\text { PCBs not contemplated by the disposal } \\
\text { regulations, and (3) regulatory } \\
\text { requirements for existing classes of PCBs } \\
\text { and PCB items. }\end{array}$ \\
\hline $\begin{array}{l}\text { Metabolism and } \\
\text { Pharmacokinetic Test } \\
\text { Guideline } \\
40 \text { CFR } 798\end{array}$ & $\begin{array}{l}\text { NPRM } \\
45 \text { FR } 32537 \\
07 / 17 / 91\end{array}$ & $\begin{array}{l}\text { EPA proposed to establish a test guideline } \\
\text { for generating metabolism and } \\
\text { pharmacokinetic data. This joint guideline } \\
\text { would harmonize the pharmacokinetics } \\
\text { testing guidelines of the Office of Toxic } \\
\text { Substances and the Office of Pesticide } \\
\text { Programs and assist EPA in developing } \\
\text { health effects test data standards for } \\
\text { testing chemicals under TSCA and the } \\
\text { Federal Insecticide }\end{array}$ \\
\hline $\begin{array}{l}\text { PCB Transformer } \\
\text { Reclassification Rule } \\
40 \text { CFR } 761\end{array}$ & $\begin{array}{l}\text { NPRM } \\
58 \text { FR } 60970 \\
11 / 18 / 93 \\
\text { Regulatory } \\
\text { Agenda } \\
\text { 59 FR 58230 } \\
11 / 14 / 94\end{array}$ & $\begin{array}{l}\text { EPA proposed to modify the current } \\
\text { reclassification requirements of } 50^{\circ} \mathrm{C} \\
\text { temperature and } 90 \text {-day testing for } \mathrm{PCB} \\
\text { transformers because results of a } \\
\text { preliminary analysis indicate many } \\
\text { transformers never reach the required } \\
\text { temperature but still reduce PCB } \\
\text { concentrations to risk-free levels. }\end{array}$ \\
\hline
\end{tabular}

(a) NPRM = Notice of Proposed Rulemaking, ANPRM = Advance Notice of Proposed Rulemaking, NOA $=$ Notice of Availability 


\section{TABLE 4-1. SUMMARY OF PROPOSED CHANGES TO EPA'S TSCA REGULATORY PROGRAM (Continued)}

\begin{tabular}{|c|c|c|}
\hline $\begin{array}{l}\text { SUBJECT } \\
\text { Affected CFR } \\
\text { Citations(s) }\end{array}$ & $\begin{array}{l}\text { STATUS }^{\mathbf{a}} \\
\text { DATE } \\
\text { (FR citation) }\end{array}$ & $\begin{array}{l}\text { DESCRIPTIVE } \\
\text { SUMMARY }\end{array}$ \\
\hline $\begin{array}{l}\text { Lead Hazard Standards } \\
40 \text { CFR } 745\end{array}$ & $\begin{array}{l}\text { Planned NPRM } \\
59 \text { FR } 57183 \\
11 / 14 / 94\end{array}$ & $\begin{array}{l}\text { EPA will identify the paint conditions and } \\
\text { lead levels in dust and soil that would } \\
\text { result in adverse human health effects. }\end{array}$ \\
\hline $\begin{array}{l}\text { Lead-Based Paint } \\
\text { Training, Accreditation, and } \\
\text { Certification } \\
40 \text { CFR } 745\end{array}$ & $\begin{array}{l}\text { NPRM } \\
59 \text { FR } 45872 \\
\text { 09/02/94 } \\
\text { Regulatory Agenda } \\
\text { 59 FR 58221 } \\
11 / 14 / 94\end{array}$ & $\begin{array}{l}\text { EPA proposed training, accreditation, and } \\
\text { certification programs governing } \\
\text { lead-based paint activities and a model } \\
\text { state program which may be adopted by } \\
\text { any state which seeks to administer and } \\
\text { enforce a state program. }\end{array}$ \\
\hline $\begin{array}{l}\text { Hazardous Air Pollutants } \\
\text { Multi-Chemical Endpoint } \\
\text { Test Rule } \\
\text { 40 CFR 789-795 }\end{array}$ & $\begin{array}{l}\text { Planned NPRM } \\
59 \text { FR } 58220 \\
11 / 14 / 94\end{array}$ & $\begin{array}{l}\text { In support of program and activities under } \\
\text { the Clean Air Act, EPA will propose a } \\
\text { multi-chemical endpoint test rule that will } \\
\text { require the testing of many chemicals for a } \\
\text { specific effect or endpoint. This type of } \\
\text { rule is an alternative to single chemical } \\
\text { rules which require testing of one } \\
\text { chemical for many effects. }\end{array}$ \\
\hline $\begin{array}{l}\text { Multi-Chemical Endpoint } \\
\text { Test Rule for } \\
\text { Bioaccumulators } \\
40 \text { CFR } 799\end{array}$ & $\begin{array}{l}\text { Planned NPRM } \\
59 \text { FR } 58223 \\
11 / 14 / 94\end{array}$ & $\begin{array}{l}\text { This multi-chemical rule for persistent } \\
\text { bioaccumulators will obtain environmental } \\
\text { effects and chemical fate data on } \\
\text { chemicals that are believed to persist and } \\
\text { bioaccumulate in the environment, in } \\
\text { particular, in sediments. EPA has identified } \\
\text { over } 30 \text { chemicals for inclusion in this rule. }\end{array}$ \\
\hline $\begin{array}{l}\text { Negotiated Consent - Procedural } \\
\text { Test Rules } \\
40 \text { CFR } 790\end{array}$ & $\begin{array}{l}\text { Planned NPRM } \\
59 \text { FR } 58222 \\
11 / 14 / 94\end{array}$ & $\begin{array}{l}\text { EPA plans to propose appropriate } \\
\text { procedural changes to reduce the resources } \\
\text { required for consent order negotiation. }\end{array}$ \\
\hline $\begin{array}{l}\text { ATSDR Substances Test Rule } \\
40 \text { CFR } 795-799\end{array}$ & $\begin{array}{l}\text { Planned NPRM } \\
59 \text { FR } 58223 \\
11 / 14 / 94\end{array}$ & $\begin{array}{l}\text { This regulation will set forth the policies } \\
\text { and procedures for using the TSCA } \S 4 \\
\text { testing authority to obtain toxicity and } \\
\text { chemical fate testing to fill certain data } \\
\text { needs identified by ATSDR in toxicity } \\
\text { profiles of chemicals prepared pursuant to } \\
\text { the Superfund Amendments and } \\
\text { Reauthorization Act. }\end{array}$ \\
\hline
\end{tabular}

(a) NPRM = Notice of Proposed Rulemaking, ANPRM = Advance Notice of Proposed Rulemaking, NOA $=$ Notice of Availability 


\begin{tabular}{|c|c|c|}
\hline $\begin{array}{l}\text { SUBJECT } \\
\text { Affected CFR } \\
\text { Citations(s) }\end{array}$ & $\begin{array}{l}\text { STATUS }^{\mathrm{a}} \\
\text { DATE } \\
\text { (FR citation) }\end{array}$ & $\begin{array}{l}\text { DESCRIPTIVE } \\
\text { SUMMARY }\end{array}$ \\
\hline $\begin{array}{l}\text { Significant New Uses of Lead } \\
40 \text { CFR } 721\end{array}$ & $\begin{array}{l}\text { ANPRM } \\
\text { 59 FR } 49484 \\
\text { 09/28/94 } \\
\text { Comment period extended } \\
\text { 59 FR 59974 } \\
11 / 21 / 94\end{array}$ & $\begin{array}{l}\text { EPA is considering the possibility of } \\
\text { issuing significant new use rules for } \\
\text { certain uses of elemental lead and lead } \\
\text { compounds under } \S 5(a)(2) \text { of TSCA. }\end{array}$ \\
\hline $\begin{array}{l}\text { Microbial Products } \\
\text { (Biotechnology) } \\
40 \text { CFR } 700 \\
40 \text { CFR } 720 \\
40 \text { CFR } 721\end{array}$ & $\begin{array}{l}\text { NPRM } \\
59 \text { FR } 45526 \\
\text { 09/01/94 } \\
\text { Regulatory Agenda } \\
\text { 59 FR 58228 } \\
11 / 14 / 94\end{array}$ & $\begin{array}{l}\text { EPA proposed procedures under } \S 5 \text { of } \\
\text { TSCA for the screening of new } \\
\text { microorganisms prior to their introduction } \\
\text { into commerce as biotechnology products. } \\
\text { The proposed rule contains mechanisms } \\
\text { for exemption as well as actual proposed } \\
\text { exemptions, guidance on how the TSCA } \\
\text { Inventory will be used, and EPA's } \\
\text { approach to research and development } \\
\text { with biotechnology organisms. }\end{array}$ \\
\hline
\end{tabular}

(a) NPRM = Notice of Proposed Rulemaking, ANPRM = Advance Notice of Proposed Rulemaking, NOA = Notice of Availability 
